\title{
Bestuurlijke verankering van innovaties in de openbare gezondheidszorg : lessen uit de casus Hartslag Limburg
}

Citation for published version (APA):

Ruland, E. C. (2008). Bestuurlijke verankering van innovaties in de openbare gezondheidszorg : lessen uit de casus Hartslag Limburg. [Doctoral Thesis, Maastricht University]. NIGZ. https://doi.org/10.26481/dis.20080620er

Document status and date:

Published: 01/01/2008

DOI:

10.26481/dis.20080620er

Document Version:

Publisher's PDF, also known as Version of record

Please check the document version of this publication:

- A submitted manuscript is the version of the article upon submission and before peer-review. There can be important differences between the submitted version and the official published version of record.

People interested in the research are advised to contact the author for the final version of the publication, or visit the DOI to the publisher's website.

- The final author version and the galley proof are versions of the publication after peer review.

- The final published version features the final layout of the paper including the volume, issue and page numbers.

Link to publication

\footnotetext{
General rights rights.

- You may freely distribute the URL identifying the publication in the public portal. please follow below link for the End User Agreement:

www.umlib.nl/taverne-license

Take down policy

If you believe that this document breaches copyright please contact us at:

repository@maastrichtuniversity.nl

providing details and we will investigate your claim.
}

Copyright and moral rights for the publications made accessible in the public portal are retained by the authors and/or other copyright owners and it is a condition of accessing publications that users recognise and abide by the legal requirements associated with these

- Users may download and print one copy of any publication from the public portal for the purpose of private study or research.

- You may not further distribute the material or use it for any profit-making activity or commercial gain

If the publication is distributed under the terms of Article $25 \mathrm{fa}$ of the Dutch Copyright Act, indicated by the "Taverne" license above, 
Bestuurlijke verankering van innovaties in de openbare gezondhe dzzorg

- lessen uit de casus H artsag Limburg 


\title{
Bestuurlijke verankering van innovaties in de openbare gezondheidszorg
}

lessen uit de casus Hartslag Limburg

\author{
Erik Ruland
}




\section{Colofon}

Titel: Bestuurlijke verankering van innovaties in de openbare gezondheidszorg; lessen uit de casus $\mathrm{H}$ artslag Limburg

Auteur: Erik Ruland

Vertaling: Chris Canter

Vormgeving: O m tekst en vorm, U trecht

D rukker: I pskamp

U itgave: N ationaal Instituut voor G ezondheidsbevordering en Ziektepreventie

(NIGZ), Woerden

Editie: 1e druk, 2008

Bestelwijze:

D eze uitgave is te bestellen bij het N IGZ, afdeling K lantenservice.

Adres: Klantenservice N I GZ, Postbus 500, 3440 AM Woerden.

Telefoon: (0348) 4376 00, (0348) 437666

E-mail: klantenservice@nigz.nl, www.nigz.nl

Bestel code: AS 061919

ISBN : 978-90-6928-254-1

NUR: 860

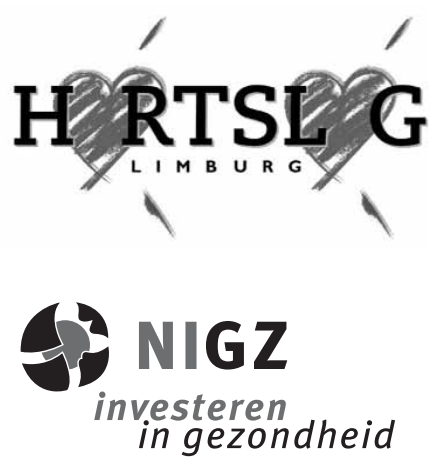

(c) N IGZ, W oerden, 2008. N iets uit deze uitgave mag zonder schriftelijke toestemming worden overgenomen. Verzoeken tot overname van beeld of tekst kunnen schriftelijk worden gericht aan Uitgeverij N IGZ, Postbus 500, 3440 AM Woerden, e-mail: uitgeverij@nigz.nl 


\section{Bestuurlijke verankering van innovaties in de openbare gezondheidszorg}

\section{lessen uit de casus Hartslag Limburg}

\section{Proefschrift}

ter verkrijging van de graad van doctor aan de U niversiteit $M$ aastricht, op gezag van de Rector M agnificus,

Prof.mr. G.P.M .F. M ols, volgens het besluit van het College van D ecanen, in het openbaar te verdedigen op vrijdag 20 juni 2008 om 14.00 uur

door

\section{Erik Comdis Ruland}


Promotores:

Prof.dr. C. Spreeuwenberg

Prof.dr. J.W. van Ree

Co-promotor:

Dr. A.J.A. van Raak

Beoordelingscommissie:

Prof.dr. J.A.M. M aarse (voorzitter)

Prof.dr. M .C.H . D onker (Erasmus M C Rotterdam / GGD Rotterdam)

Prof.dr. N .S. Klazinga (AM C / U vA Amsterdam)

Prof.dr. J.F.M . M etsemakers

Prof.dr. N.K. deVries

$\mathrm{H}$ et verschijnen van dit proefschrift is mede mogelijke gemaakt door het $\mathrm{N}$ ationaal Instituut voor G ezondheidsbevordering en Ziektepreventie (N IGZ) en subsidies van de $\mathrm{N}$ ederlandse $\mathrm{H}$ artstichting en ZonM w. 
M otto

Gelukkige gezinnen zijn allemaal hetzelfde, maar ieder ongelukkig gezin is ongelukkig op zijn eigen manier.

(Tolstoj, Anna Karenina) 


\section{Inhoudsopgave}

Voorwoord

H oofdstuk 1 Inleiding

$\begin{array}{lll}1.1 & \text { Introductie } & 15\end{array}$

1.2 Probleemstelling 16

$\begin{array}{ll}1.3 & \text { D oelstelling en vraagstelling } \\ 1.4 & 18\end{array}$

$\begin{array}{ll}1.4 \text { Leeswijzer } & 19\end{array}$

$\mathrm{H}$ oofdstuk $2 \mathrm{D}$ e opbouw van $\mathrm{H}$ artslag Limburg

2.1 Inleiding 21

2.2 De uitgangssituatie: een visie, ontluikende samenwerkingsrelaties 22 en een 'window of opportunity'

2.3 Het ontwikkelen van een gezamenlijke visie 22

2.4 Het plan: H artslag Limburg 25

2.5 Van visie naar 'plan plus contract' 27

2.6 Discussie 31

H oofdstuk 3 O nderzoeksopzet

3.1 Inleiding 35

3.2 Het WIZ-model $\quad 35$

3.3 Uitwerking van de vraagstelling 44

3.4 Methode 45

3.5 Conclusie $\quad 55$

H oofdstuk 4 D e casus: de bestuurlijke verankering van $\mathrm{H}$ artslag Limburg

4.1 Inleiding 57

4.2 De bestuurlijke verankering: begin- en eindmeting 57

4.3 H et bestuurlijk proces: een chronologisch overzicht 59

$\begin{array}{ll}4.4 \text { Conclusie } & 71\end{array}$

H oofdstuk 5 Externe factoren

5.1 Inleiding 73

$\begin{array}{lll}5.2 & 0 \text { verheidsbeleid } & 75\end{array}$

$\begin{array}{ll}5.3 \text { O pstelling financiers } & 79\end{array}$

5.4 Conclusie 82 
H oofdstuk 6 Lokale context

6.1 Inleiding 85

6.2 Bestaande samenwerkingsrelaties 87

6.3 Kenmerken van bedrijfsvoering' 93

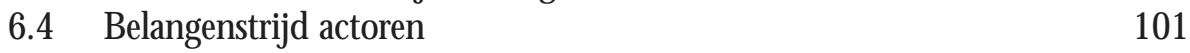

6.5 Conclusie 111

H oofdstuk 7 Leiderschap, regierol en verandermanagement?

7.1 Inleiding

7.2 Theorieen over leiderschap 113

7.3 Een definitie van leiderschap 114

7.4 D efinitie van de regierol van gemeenten 116

7.5 D efinitie van verandermanagement en leiderschap vanuit de GGD 120

7.6 Conclusie

H oofdstuk 8 Verandermanagement en leiderschap

$\begin{array}{ll}8.1 \text { Inleiding } & 123\end{array}$

8.2 Defeitenbeschrijving 124

8.3 De belangrijkste veranderacties per jaartal 129

8.4 Discussie en conclusie 148

H oofdstuk 9 D e regierol van gemeenten

9.1 Inleiding 151

9.2 Resultaten regierol van gementen 152

$\begin{array}{ll}9.3 \text { Discussie en conclusie } & 157\end{array}$

H oofdstuk 10 D raagvlak

10.1 Inleiding 159

10.2 D raagvlak: resultaten uit de feitenbeschrijving 159

10.3 D raagvlak: resultaten uit de enquêtes 167

$\begin{array}{ll}10.4 \text { D raagvlak: resultaten uit de interviews } & 179\end{array}$

10.5 Triangulatie en conclusie 183

H oofdstuk 11 Conclusies en aanbevelingen

11.1 Inleiding 185

11.2 Conclusies 185

11.3 Discussie 190

11.4 Beschouwing 196

$\begin{array}{ll}11.5 \text { Aanbevelingen } & 199\end{array}$ 
N awoord

Samenvatting

Summary

G ehanteerde begrippen en afkortingen

Literatuur

$O$ verzicht databronnen

233

Bijlage 1: Tabel Factoren en veronderstellingen behorend bij het WIZ-model 245

D ankwoord

253

Curriculum Vitae

255

Bijlage 2: Feitenbeschrijving (1e deel van de tijdreeksanalyse):

zie CD -rom

Bijlage 3: Interviews en synthese expertpanel

zie CD -rom

Bijlage 4: Voorbeeld vragenlijsten:

zie CD-rom 


\section{Voorwoord}

Eind 1994 deed zich een bijzondere kans voor. D e N ederlandse H artstichting organiseerde en landelijke expertmeeting waarvan de conclusie luidde dat de tijd rijp was voor een preventieproject dat de krachten van gemeenten, GGD, huisartsen en het ziekenhuis zou bundelen. D e H artstichting gaf aan bereid te zijn om een dergelijk nieuw initiatief financieel te ondersteunen. $0 p$ basis van deze informatie nam de burgemeester van de gemeente $M$ eerssen, tevens bestuurslid van de $\mathrm{N}$ ederlandse $\mathrm{H}$ artstichting, een initiatief. $\mathrm{H}$ ij organiseerde op 23 november 1994 op het gemeentehuis een breed overleg met vertegenwoordigers van de GGD Zuidelijk Zuid-Limburg, het streekgewest, huisartsen, U niversiteit M aastricht en academisch ziekenhuis. Vrij snel bleek er consensus om gezamenlijk een raamplan op te stellen voor de preventie van hart- en vaatziekten op regionaal niveau. Dit initiatief mondde uit in het project $\mathrm{H}$ artslag Limburg, dat in 1998 van start ging in alle vijf de gemeenten van de regio $M$ aastricht.

In de loop van het jaar 2000 begon tot het projectteam van GGD en U niversiteit $M$ aastricht door te dringen dat de doelstelling om een blijvende samenwerking tussen de participerende organisaties op te bouwen meer dan speciale aandacht vroeg. 0 pgemerkt werd dat de professionele samenwerking op uitvoerend niveau en het behalen van tussentijdse resultaten nog geen garantie boden voor aanhoudend draagvlak op bestuurlijk niveau. Duidelijk werd ook dat veel innovatieve projecten hierop vastlopen. $\mathrm{N}$ a de projectfase stopt ook de samenwerking als die samenwerking niet wordt opgenomen, of 'verankerd', in duurzaam beleid. D e vragen die vervolgens oprezen waren: hoe kan een projectleider vanuit de GGD dit probleem aanpakken, en, kunnen we dit zorgvuldig onderzoeken? Wat volgde was een zoektocht langs verschillende deskundigen en modellen uit de literatuur. U iteindelijk vonden we dicht bij huis wat we zochten. Bij de vakgroep Beleid, Economie en O rganisatie van de Zorg (BEOZ) van de Universiteit werd al enige jaren onderzoek naar samenwerking in de zorg verricht, en het daar ontwikkelde theoretisch model kon als basis dienen voor onze ambities. M et steun van de N ederlandse H artstichting en de GGD werd een onderzoeksvoorstel geschreven, en dit resulteerde medio 2002 in een subsidie van ZonM w. N aast het al lopende onderzoek naar processen, effecten en kosten effectiviteit van $\mathrm{H}$ artslag Limburg konden we nu een begin maken met onderzoek naar het bestuurlijke samenwerkingsproces. H oe dit onderzoek verlopen is en welke lessen daar uit te leren zijn vindt u op de volgende pagina's. 


\section{Hoofdstuk 1 Inleiding}

\subsection{Introductie}

In het huidige informatietijdperk komt de complexiteit van allerlei maatschappelijke problemen veelvuldig over het voetlicht. Gezondheid en ook de publieke gezondheidszorg winnen aan belang. Er is een breed besef ontstaan dat belangrijke thema's als overgewicht, sociaal-economische gezondheidsverschillen en vele ziekte specifieke aandoeningen, zeer complexe oorzaken hebben en alleen aangepakt kunnen worden wanneer vele partijen uit verschillende sectoren samenwerken. Behalve nieuwe maatregelen van de rijksoverheid is de laatste jaren een accent gelegd op het belang om binnen de zorgsector zelf preventie en curatie beter te integreren. D eze 'nieuwe' brede gezondheidsbenadering vormt sinds kort ook nadrukkelijker uitgangspunt voor het beleid van het ministerie van VWS (M in. VWS, 2007).

Samenwerking is dus een thema, zowel op landelijk als op lokaal niveau. D ie samenwerking wordt van uitdaging tot een prioriteit wanneer geconstateerd wordt dat het bij de publieke gezondheidszorg gaat om een blijvende randvoorwaarde. Al in 2002 signaleerde het RIVM het belang om te blijven investeren in zowel preventieve voorzieningen als in de samenwerking op lokaal niveau die hierbij nodig is (van 0 ers, 2002). "D e verbetering van de N ederlandse volksgezondheid stagneert, en ongezond gedrag is daarvan de belangrijkste oorzaak." O $\mathrm{m}$ dit aan te pakken "moeten preventiespelers op lokaal niveau de krachten bundelen."

$0 p$ het lokale niveau zijn gemeenten en GGD belangrijke spelers. De Wet Collectieve Preventie Volksgezondheid (W CPV) draagt gemeenten op de regierol vorm te geven en deelt een coördinerende taak toe aan de GGD. D at dit voor beiden geen eenvoudige opgave is wordt onder andere door de Inspectie voor de gezondheidszorg gesignaleerd (Staatstoezicht, 2005). D e inspectie concludeert dat in het licht van de toenemende maatschappelijke opgave de uitvoering op gemeentelijk niveau zorgwekkend is en maatregelen onvoldoende worden geconcretiseerd. Gemeenten wijzen in hun reactie hierop onder andere op een structureel tekort aan middelen (V N G, 2006b).

$H$ et is in deze context dat vanuit GGD'en en kennisinstituten initiatieven genomen worden om de kwaliteit van de publieke gezondheidszorg, en specifiek ook de gezondheidsbevordering, te verbeteren. D e ervaring leert echter dat ook succesvolle projecten lang niet altijd geïmplementeerd worden. Een belangrijk inzicht van het laatste decennium is geweest dat dit te maken heeft met het bestuurlijk niveau. Illustratief hiervoor is de aanscherping van de W CPV in 2002 die gemeenten opdraagt om een lokale nota volksgezondheidsbeleid te 
maken. M et deze opdracht wordt de keuze over de inhoud van het gezondheidsbeleid gekoppeld aan de besluitvorming over de financiering, en dat is helder. Immers, wie betaalt, bepaalt. Anders gezegd: professionele inzichten en voorstellen gaan pas werken wanneer ze op politiek en bestuurlijk niveau leiden tot erkenning en positieve besluitvorming over de benodigde financiering. $H$ etzelfde geldt dus voor het realiseren van samenwerking: ook die kan alleen duurzaam worden wanneer zij op bestuurlijk niveau wordt verankerd. En dat nu stelt de betrokken partijen voor een belangrijke uitdaging, want de ervaring is op dit terrein nog tamelijk schaars. Ervaringen uit de curatieve sector, waar al heel wat kennis is opgedaan over transmurale samenwerking en 'ketenzorg', kunnen tot voorbeeld dienen, maar het speelveld van de publieke gezondheidszorg, met name de gezondheidsbevordering, heeft ook afwijkende kenmerken. D e belangrijkste daarvan zijn wellicht het ontbreken van overtuigende korte termijn resultaten en de lage prioriteit die gezondheidsbevordering doorgaans krijgt.

In het licht van deze kenmerken is het niet zo vreemd dat lokale samenwerking moeizaam van de grond komt. $0 \mathrm{~m}$ dit te kunnen verbeteren is specifieke kennis nodig over hoe verankering van samenwerking in de publieke gezondheidszorg in de praktijk verloopt, welke factoren daarbij een rol spelen en hoe die factoren beïnvloed kunnen worden.

\subsection{Probleemstelling}

Kenmerkend voor de N ederlandse situatie is de rol van de gemeente en de functie van de GGD 'en als regionale uitvoerende professionele organisaties ten dienste van de gemeenten. D oordat de GGD op professioneel niveau verantwoordelijk is voor de coördinatie van public health (WCPV), functioneert deze dienst ook nadrukkelijk als 'interface' tussen het openbare bestuur en de reguliere, c.q. curatieve gezondheidszorg. D oor deze positie is de GGD bij uitstek aangewezen om een rol te spelen als makelaar om regionale en lokale samenwerking te realiseren. $D$ aar staat echter tegenover dat de wettelijke bevoegdheden om die rol te vervullen beperkt zijn. Bovendien ligt de bestuurlijke verantwoordelijkheid bij gemeenten. De GGD zal dus vooral op basis van gezag en overtuiging moeten opereren. In dit spanningsveld van een verscheidenheid aan spelers met verschillende verantwoordelijkheden en mogelijkheden, is het realiseren van samenwerking een hele uitdaging.

Verder speelt mee dat op het terrein van preventie, en specifiek de gezondheidsbevordering, het moeilijk en soms onmogelijk is om snel overtuigende resultaten te boeken. D e beschikbare wetenschappelijk evidence voor de effectiviteit van lokale gezondheidsbevordering is bovendien nog beperkt ( $\mathrm{H}$ ollander et al., 
2006), wat betekent dat niet iedereen overtuigd is van de juistheid van deze aanpak. Beide gegevens leggen extra druk op het draagvlak voor gezondheidsbevordering binnen het openbaar bestuur en de reguliere zorg. Dit alles maakt realisatie van samenwerking onder het coördinatorschap van de GGD ingewikkeld. 'D raagvlak' is volgens de literatuur een noodzakelijke voorwaarde. $M$ aar hoe draagvlak voor 'new public health' binnen zowel het openbaar bestuur als de reguliere zorgsector versterkt kan worden is verre van duidelijk. Er is behoefte aan inzicht in factoren die bevorderend dan wel belemmerend werken, én inzicht in strategieën die effectief zijn in het beïnvloeden van die factoren. Binnen dit relatief nieuwe probleemveld zullen de ervaringen van voorbeeldprojecten benut moeten worden om kennis te genereren over hoe gestimuleerd kan worden dat eenmaal gerealiseerde samenwerking ook daadwerkelijk bestuurlijk verankerd wordt.

\section{Hartslag Limburg}

Eén zo'n voorbeeldproject is het project H artslag Limburg. Vanaf 1998 is er in de regio Zuidelijk Zuid-Limburg door middel van dit project intensieve samenwerking gerealiseerd op het gebied van de gezondheidsbevordering. Twaalf lokale partners waaronder gemeenten, welzijnswerk, GGD, huisartsen, specialisten in het academisch ziekenhuis en een zorgverzekeraar, werkten samen aan de bestrijding van hart- en vaatziekten. Een belangrijke doelstelling van het project was om gezamenlijk te komen tot een blijvende vernieuwing in de samenwerking. M edio 2002, op het moment van de aanvang van dit onderzoek, bevond $\mathrm{H}$ artslag Limburg zich in de tweede projectperiode, een periode die liep van begin 2001 tot eind 2003. G emeenten en een zorgverzekeraar waren op dat moment de belangrijkste financiers, en zij hadden eerder extra gelden voor de tweede fase uitgetrokken. In deze fase moesten verschillende uitvoerende en onderzoeksmatige projectonderdelen tot een afronding komen en moesten er besluiten genomen worden over het al dan niet continueren van de onderlinge samenwerking vanaf 2004 (derde fase). M edio 2002 gaven alle lokale partners aan de samenwerking op bestuurlijk en uitvoerend niveau in principe te willen continueren dan wel dit serieus te overwegen.

Een extra argument om juist deze casus te benutten ligt in het feit dat $\mathrm{H}$ artslag Limburg begeleid werd met uitgebreid evaluatieonderzoek op niveau van processen (realisatie van gezondheidsactiviteiten), effecten (beoogde reductie van het voorkomen van ongezonde leefgewoonten en veranderingen van biomedische risicofactoren) en kosten effectiviteit. Te verwachten was dat dankzij dit al lopende onderzoek ook de invloed van de beschikbaarheid van 'evidence' en 'cijfers' op de bestuurlijke besluitvorming in deze studie meegenomen kon worden. 
Tot slot is meegewogen dat het onderwerp van $\mathrm{H}$ artslag Limburg, de preventie van hart- en vaatziekte, geen belemmering vormt om vanuit de casus inzichten te kunnen extrapoleren naar een al gemeen niveau. C entraal staan immers de actoren en processen op bestuurlijk niveau en deze actoren zijn veelal dezelfden die ook op andere preventieonderwerpen de bestuurlijke besluitvorming bepalen.

Al met al bood $\mathrm{H}$ artslag Limburg dus een uitgelezen gelegenheid om inzicht te verwerven in het brede palet van factoren dat invloed heeft op de verankering van samenwerking binnen de publieke gezondheidszorg.

\subsection{Doelstelling en vraagstelling}

D oel van dit onderzoek is om inzicht te verwerven over hoe vanuit het manage ment van de GGD bijgedragen kan worden aan het realiseren van bestuurlijke verankering van samenwerking in de publieke gezondheidszorg. Vertrekpunt is dat verankerde samenwerking de resultante is van verschillende factoren die het draagvlak voor samenwerking kunnen bevorderen dan wel belemmeren. O nder die factoren vallen bijvoorbeeld lokale omstandigheden, en ook externe factoren. Externe factoren zijn vanuit het lokale niveau meestal amper te beïnvloeden. Vandaar dat deze factoren als 'gegeven' worden beschouwd. 0 ok aspecten van de structuur van de lokale context worden als 'gegeven' beschouwd (aanwezige organisaties, van toepassing zijnde wet- en regelgeving, en dergelijke). D it wordt echter onderscheiden van elementen in de lokale context die eveneens gegeven zijn, maar wèl beïnvloedbaar zijn vanuit de GGD (bijvoorbeeld: onderlinge relaties, aspecten van bedrijfsvoering en besluitvorming). D e activiteiten die vanuit het management van de GGD ondernomen worden om factoren te beïnvloeden en verankering van samenwerking te bevorderen, worden hier gebundeld onder de noemer 'verandermanagement'.

O bject van onderzoek is de samenwerking tussen de betrokken gemeenten en de GGD en de overige projectpartners, het welzijnswerk, huisartsen, het academisch ziekenhuis en de zorgverzekeraar binnen het project $\mathrm{H}$ artslag Limburg. O nder verankering van samenwerking wordt verstaan duurzaam bestuurlijke samenwerking die gekenmerkt wordt door expliciete afspraken op vier aspecten, te weten: formalisatiegraad, duurzaamheid, inzet van middelen en reikwijdte. D e centrale vraagstelling in deze studie is derhalve:

$0 p$ welke manier en in welke mate kan verandermanagement vanuit de GGD, gegeven de context van lokale omstandigheden en externe factoren, bijdragen aan bestuurlijke verankering van regionale samenwerking in de publieke gezondheidszorg? 
Essentie van deze studie is te documenteren of, en in welke mate, in de casus $\mathrm{H}$ artslag Limburg, elementen van verandermanagement succesvol worden toegepast en deze, gegeven de lokale context en externe factoren, bijdragen aan bestuurlijke verankering van samenwerking. $D$ e centrale vraagstelling is daartoe uitgewerkt in zeven deelvragen. D e deelvragen en de verdere onderzoeksopzet worden behandeld in hoofdstuk 3 .

\subsection{Leeswijzer}

In het volgende hoofdstuk wordt beschreven wat vooraf ging aan de opzet van deze studie, namelijk de opbouw van het project $\mathrm{H}$ artslag Limburg, de ervaringen die bijdroegen aan de aandacht voor de samenwerking op het bestuurlijk niveau en de bevorderende en belemmerende factoren die hierbij opvielen. In hoofdstuk 3 wordt de centrale vraagstelling uitgewerkt, evenals het gehanteerde theoretisch model en de gehanteerde onderzoeksmethode. Toegelicht wordt hoe het theoretisch model in de loop van het onderzoek gevalideerd en aangepast werd.

H oofdstuk 4 opent met het resultaat van de bestuurlijke verankering van $\mathrm{H}$ artslag Limburg, gevolgd door een chronologische beschrijving van het hele proces door de jaren 2002 - 2005. Die beschrijving geeft een eerste blik op welke factoren allemaal een rol gespeeld hebben.

In de daarop volgende hoofdstukken worden de verschillende clusters van factoren, in het onderzoeksmodel 'dimensies' genoemd, apart nader geanalyseerd. $\mathrm{H}$ oofdstuk 5 gaat in op de invloed van externe factoren, hoofdstuk 6 de dimensie lokale context. In hoofdstuk 7 wordt het onderscheid tussen leiderschap, regierol en verandermanagement uitgewerkt. $D$ aarmee is de basis gelegd voor de analyse in hoofdstuk 8 over verandermanagement en leiderschap vanuit de GGD , en de analyse in hoofdstuk 9 van de regierol van gemeenten. In hoofdstuk 10 wordt de analyse van de dimensie draagvlak gepresenteerd, waarna in hoofdstuk 11 de resultaten uit de eerdere hoofdstukken gebundeld worden en uitmonden in conclusies en aanbevelingen. 


\section{Hoofdstuk 2 De opbouw van Hartslag Limburg}

(samengesteld op basis van artikel eerder verschenen in TSG (Ruland, 2006a))

\section{$2.1 \quad$ Inleiding}

D it hoofdstuk beschrijft hoe de opbouw van het modelproject $\mathrm{H}$ artslag Limburg tot stand kwam. D oel van dit project was om een blijvende vernieuwing te ontwikkelen voor de regionale preventie van hart- en vaatziekten. G estart werd vanuit het principe om zowel lokale bevolking als bestaande zorgverleners en instellingen te betrekken in gezondheidsbevorderende acties en werkwijzen. In de drie jaar durende opbouwfase werden stapsgewijs bijdragen vanuit onderzoek, praktijk en beleid aan elkaar gesmeed. D uidelijk wordt welke kenmerken aan deze infrastructuur voor publieke gezondheid zijn te onderscheiden. Implementatie van de hoofdlijnen van het Charter van 0 ttawa (W H O, 1986) bleek hiermee haal baar, een opmerkelijke mijlpaal.

D e opbouw van de samenwerking werd mogelijk gemaakt door enkele belangrijke bevorderende factoren: de meedenkende en stimulerende rol van een hoofdsponsor, lokale politieke betrokkenheid, een positief investeringsklimaat, stapsgewijze opbouw met partners die al langere tijd samenwerken en sociaal ondernemerschap. Reflectie op deze factoren, plus de ervaringen die met de samenwerking in de loop van het project werden opgedaan, leiden tot de ambitie om de beoogde verankering van de samenwerking onderzoekbaar te maken.

Sinds het verschijnen van de Volksgezondheid Toekomst Verkenning 2002 (van 0 ers, 2002) is het belang van het bevorderen van gezond gedrag op lokaal niveau sterker naar voren gekomen. H oe gezondheidsbevordering op lokaal niveau opgebouwd zou moeten worden is onder andere door de Wereldgezondheidsorganisatie (W H O) verwoord in het 0 ttawa Charter van 1986 (W H O , 1986). C entrale begrippen uit dit internationale charter zijn participatie van lokale groepen ('community-based'), de realisatie van een gezondheidsbevorderende omgeving (supportive environments), pleitbezorging voor gezond beleid (advocacy) en een heroriëntatie van gezondheidsinstellingen van curatie naar preventie (zie figuur 2.1). Tot een daadwerkelijke toepassing van alle elementen van het $\mathrm{C}$ harter is het in $\mathrm{N}$ ederland amper gekomen. $\mathrm{N}$ iet vreemd als men beseft dat het $\mathrm{O}$ ttawa $\mathrm{C}$ harter vraagt om opbouw van samenwerking tussen instellingen binnen en buiten de zorgsector die merendeels gescheiden van elkaar functi- 
oneren. Vraag is dus: als er voorbeel den van integrale samenwerking zijn, hoe is die samenwerking opgebouwd? M eer precies: welke stappen worden ondernomen en welke elementen kenmerken de infrastructuur?

$O$ ver deze vragen is tot nu zeer weinig gepubliceerd. D e spaarzame beschikbare ervaringen, zoals die in Rotterdam, leren dat de opbouw van samenwerking op lokaal niveau tijd vergt en soms teleurstellend verloopt (de H aes et al., 2002; Voorham et al., 2002). O nafhankelijk van 'Rotterdam' is vanaf 1994 in de regio Zuidelijk Zuid-Limburg gewerkt aan een soortgelijk ideaal. D it hoofdstuk beschrijft achtereenvolgens: de uitgangssituatie (paragraaf 2.2), het ontwikkelen van een gezamenlijke visie (paragraaf 2.3), het uiteindelijke plan (paragraaf 2.4) en het traject van de visie naar 'plan plus contract' (paragraaf 2.5). In de discussie wordt gereflecteerd op de factoren die met name in de opbouwfase bevorderend en belemmerend hebben gewerkt.

\section{OTTAWA CHARTER FOR HEALTH PROMOTION}

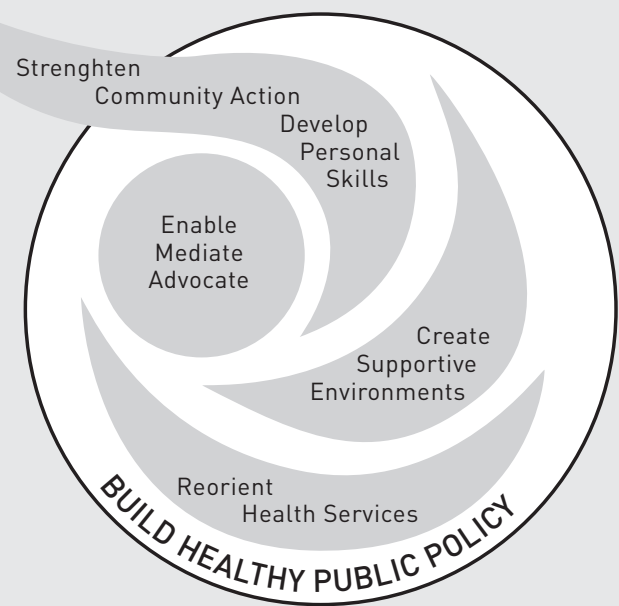

Figuur 2.1 The Ottawa Charter, 1986

\subsection{De uitgangssituatie: een visie, ontluikende samen- werkingsrelaties en een 'window of opportunity'}

Begin jaren negentig ontwikkelde de GGD Zuidelijk Zuid-Limburg voor haar vijf gemeenten en 180.000 inwoners een nieuwe visie op preventie. Centraal in 
deze visie stond een 'integrerende benadering': een samen met andere partijen op te zetten programmering, gericht op het vormgeven aan preventie vanuit de bestaande werkwijze van alle belangrijke actoren, zowel in de zorg als daarbuiten. De GGD wilde zich daarbij concentreren op de epidemiologisch gezien top acht belangrijkste gezondheidsthema's, de zogenoemde 'volksziekten': infectieziekten, hart- en vaatziekten, kanker, cara, psychische ziekten, ontwikkelingsstoornissen, letsels en mondziekten (GGD Zuidelijk Zuid-Limburg, 1989). $M$ ede op grond van de regionale oversterfte ten opzichte van het landelijke gemiddelde werd hart- en vaatziekten geselecteerd als eerste thema om verder uit te werken. Als eerste stap volgde een brede inventarisatie van wat er al in de regio op dit gebied werd gedaan, en wat er via de versterking van preventie in nulde, eerste en tweede lijn verbeterd zou kunnen worden (Jansen et al., 1992; Ruland et al., 1994). D ertien aanbevelingen werden geformuleerd rond de prioritaire thema's roken, voeding, achterstandsgroepen en vroegopsporing via huisartspraktijken. D e feitelijke ambitie om een en ander aan te pakken bleef echter beperkt daar het werkbudget slechts tienduizend gulden bedroeg. Wat wel lukte waren kleine stapjes. Een sinds 1992 lopend epidemiologisch onderzoek vanuit het academisch ziekenhuis M aastricht (azM) naar de prevalentie van plotse hartdood, werd vanuit de GGD benut om in het verlengde van dat onderzoek gezamenlijk nieuwe deelprojecten uit te voeren (reanimatiecursussen, regionale campagne voor rookvrije ruimten).

Eind 1994 deed zich een bijzondere kans voor. D e N ederlandse $\mathrm{H}$ artstichting organiseerde een landelijke expertmeeting waarvan de conclusie luidde dat de tijd rijp was voor een preventieproject dat de krachten van gemeenten, GGD , huisartsen en het ziekenhuis zou bundelen. $\mathrm{De} \mathrm{H}$ artstichting gaf aan bereid te zijn om een dergelijk nieuw initiatief financieel te ondersteunen. Achtergrond hiervoor was het interne beleid van de $\mathrm{H}$ artstichting: van de drie doelstellingen te weten onderzoek, patiëntenzorg en preventie, bleek preventie onvoldoende uit de verf te komen. Er was behoefte aan een vernieuwende aanpak met uitstraling. $0 p$ basis van deze informatie nam de burgemeester van de gemeente $\mathrm{M}$ eerssen, tevens bestuurslid van de $\mathrm{N}$ ederlandse $\mathrm{H}$ artstichting, een initiatief. $\mathrm{H}$ ij organiseerde op 23 november 1994 op het gemeentehuis een breed overleg met vertegenwoordigers van GGD, het streekgewest, huisartsen, universiteit $M$ aastricht (U M ) en ziekenhuis. Vrij snel bleek er consensus om gezamenlijk deze 'window of opportunity' te benutten. Uitkomst van het overleg was de samenstelling van een Redactiecommissie (noot a)), die opdracht kreeg om binnen een half jaar een raamplan op te stellen voor de preventie van hart- en vaatziekten op regionaal niveau. 


\subsection{Het ontwikkelen van een gezamenlijke visie}

Inzet voor de Redactiecommissie was het realiseren van een modelproject waarmee aantoonbare resultaten behaald zouden kunnen worden, relevant voor het landelijke beleid. Voortbouwend op eerdere ervaringen (van Assema, 1993; Bracht 1990; Pyorala, 1994) leidde dit tot de volgende uitgangspunten:

- O pzet van een integrale aanpak die interventies voor de hele bevolking, en daarbinnen vooral voor lage sociaal economische status (LSES-) groepen, weet te verenigen met interventies voor medische hoogrisicopatiënten bij huisartsen en in het ziekenhuis.

- Zo veel mogelijk aansluiten bij 'het bestaande': bestaande lokale samenwerking, initiatieven, werkwijzen, al bewezen effectieve interventies, etc..

- Participatie van de doelgroep: van de bevolking, gemeenten en intermediairen via lokale werkgroepen, van huisartsen en specialisten via bestaande en ad hoc overlegmogelijkheden.

- Wetenschappelijke evaluatie van de processen, de effecten en de kosten van het hele project.

- Continuering op lange termijn: de vernieuwing dient blijvend ingebouwd te worden.

- Kwaliteitsbewaking voor alle interventies in de praktijk.

- ledere deelnemende partner dient ook uit eigen middelen bij te dragen

- Een betekenisvolle omvang, geschat op een investeringsbedrag van minimaal $€ 450.000$ per jaar (!).

Als doelstellingen werden geformuleerd:

- M eetbare reductie van drie belangrijke risicofactoren: roken, vetconsumptie en lichamelijke inactiviteit, uitgedrukt in percentages reducties, te meten op zowel populatieniveau als op patiëntniveau en in gelijke mate bij de lage SES doelgroep als bij andere SES groepen.

- Realiseren van een blijvende samenwerking tussen de drie echel ons (publieke gezondheidszorg, huisartsen en specialisten).

M et het bereiken van consensus op hoofdlijnen kon nu de volgende stap gemaakt worden: het aanleveren van onderdelen voor het beoogde raamplan. M edio 1995 werd dit plan ter beoordeling voorgelegd aan de $\mathrm{N}$ ederlandse $\mathrm{H}$ artstichting. Voorjaar 1996 mondde dit proces uit in een opdracht van de $\mathrm{N}$ ederlandse $\mathrm{H}$ artstichting aan de projectleider van de GGD om het raamplan uit te werken tot een gedetailleerd projectvoorstel. Financiering van het uiteindelijke plan was eind 1997 rond, zodat begin 1998 feitelijk gestart kon worden met een nulmeting op populatieniveau. 


\subsection{Het plan: Hartslag Limburg}

$\mathrm{H}$ artslag Limburg is opgebouwd uit twee projecten of deeltrajecten (zie figuur 2.2)(Ruland 1999a en 1999b). In het Community-project werden er gezondheidsbevorderende activiteiten en campagnes opgezet voor de hele bevolking, met een nadruk op LSES-groepen daarbinnen. In het $\mathrm{H}$ oogrisico-project lag de focus op patiënten met een al bekend medisch hoog risico op het krijgen van hart- en vaatziekten.

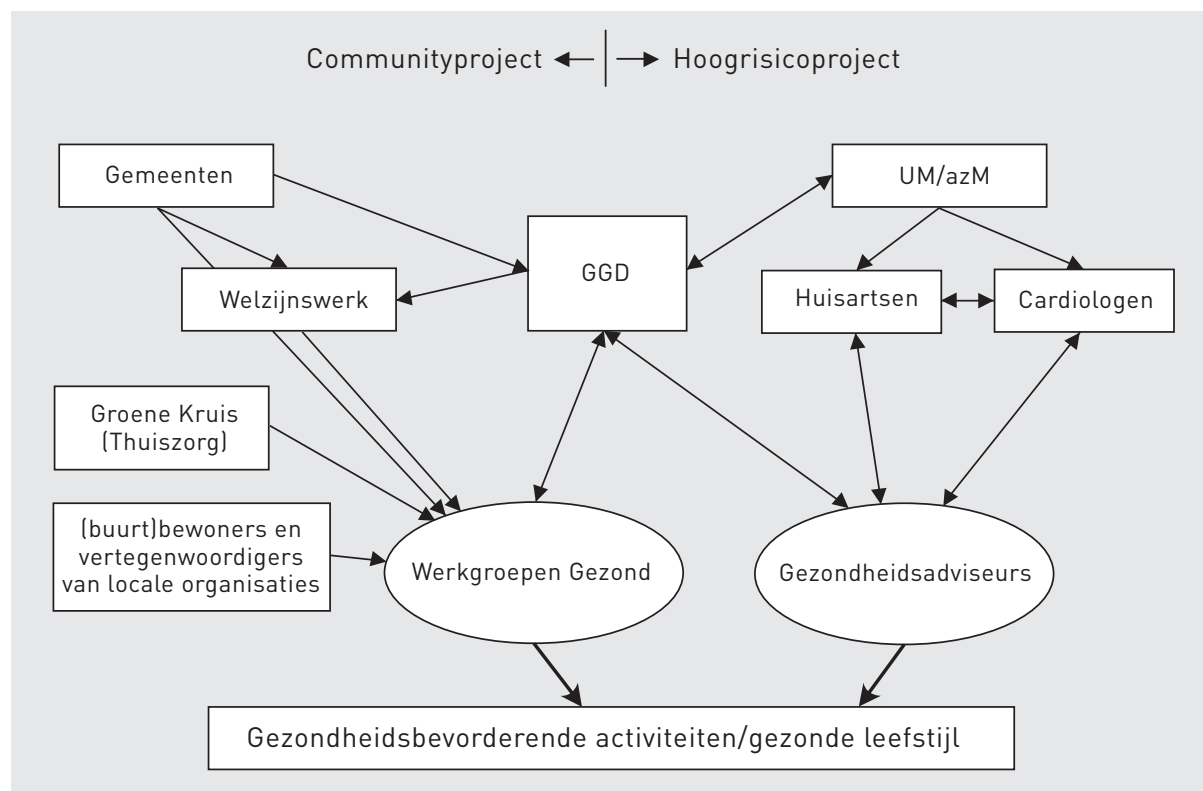

Figuur 2.2 Samenwerkingsstructuur van Hartslag Limburg

\subsubsection{Gemeentelijk gezondheidsbeleid: het Community-project}

Vanuit het Community-project werden er acht lokale 'Werkgroepen G ezond' opgericht: één in iedere participerende kleine gemeente en daarnaast vier verspreid over evenzoveel $M$ aastrichtse volksbuurten. Elke werkgroep bestond uit vertegenwoordigers van allerlei organisaties / doelgroepen in de gemeente of buurt en werd professioned ondersteund door een gezondheidsvoorlichter (GVO ), een welzijnswerker en een gemeenteambtenaar (zie figuur 2.2). D e belangrijkste taak van de werkgroepen was om gezondheidsbevorderende activiteiten op te zetten in de eigen gemeenschap die erop gericht waren om inwoners te helpen te stoppen met roken, gezonder te gaan eten en meer te bewegen. D e proces- en 
effectresultaten evenals de praktische ervaringen van jarenlang werken met lokale werkgroepen zijn uitgebreid beschreven (Assema et al, 2006; Ronda, 2003; Ronda et al., 2004).

\subsubsection{Preventie in eerste en tweede lijn: het Hoogrisico-project}

Kern van het $\mathrm{H}$ oogrisico-project was de gedachte dat voor de doelgroep met het hoogste individuele risico een persoonlijke begeleiding in het verwerven van een gezonde leefstijl geëigend is. H et project werd opgezet als een gerandomiseerde studie waarbij in 25 huisartspraktijken en op de poli $\mathrm{C}$ ardiologie van het azM tezamen ruim 2700 patiënten werden opgespoord met een risico van meer dan $20 \%$ op het krijgen van een cardiovasculair incident binnen de eerstvolgende 10 jaar. D it betrof dus merendeels patiënten met multiple risicofactoren, diabetici en infarctpatiënten. D e interventie bestond uit het completeren van het risicoprofiel door huisarts/cardioloog, het evalueren en zonodig optimaliseren van de behandeling en het aanbieden van een aantal counselinggesprekken. D eze gesprekken werden uitgevoerd door een viertal speciaal opgeleide functionarissen: de 'gezondheidsadviseurs'. D e ervaringen en resultaten van het $\mathrm{H}$ oogrisicoproject zijn inmiddels uitgebreid beschreven ( $\mathrm{H}$ arting, 2005 en 2006).

\subsubsection{Rol GGD: netwerkmanagement}

Voor de opbouw en uitvoering van interventies en onderzoek in beide deelprojecten was samenwerking en onderlinge communicatie tussen een groot aantal actoren een vereiste. Vanaf het begin spraken partijen in dit netwerk de GGD hierop aan, vandaar de centrale positie van de GGD in figuur 2.2. D it 'netwerkmanagement' betrof, behalve de inzet van de projectleider, een coördinator Community-project, PR-functionaris en middelen. Activiteiten richtten zich zowel op projectmanagement (aansturen van ontwikkeling en organisatie van concrete interventies, voortgangsbewaking uitvoering en onderzoek) als op procesmanagement (informeren van alle betrokkenen, organiseren van inspraak, bevorderen van draagvlak). N aast advertenties in lokale media werd bij voorkeur gewerkt via informatiekanalen van de partners: gemeentepagina's, huisbladen van azM , thuiszorg en welzijnswerk, wijkkranten, etc.. Procesmanagement kreeg daarnaast vorm via de publicatie van een $\mathrm{H}$ artslag $\mathrm{N}$ ieuwsbrief, jaarlijkse miniconferenties met alle betrokkenen, inclusief bestuurders, en verschillende overlegvormen met ambtenaren. De kosten van netwerkmanagement bedroegen jaarlijks ongeveer $€ 120.000$ (waarvan $€ 22.000$ voor management van de samenwerking GGD , UM en RIVM ), ofwel $15 \%$ van het totaal van $€ 813.000$ 
(prijspeil 2003); ter vergelijking: het Community-project kostte jaarlijks $€ 319.000$, het $\mathrm{H}$ oogrisico-project $€ 104.000$ en het evaluatieonderzoek

$€ 270.000$. Elders is beschreven dat juist dit netwerkmanagement heeft geleid tot een hoog niveau van 'cost sharing' en sponsoring door derden (Ronckers et al., 2006a).

\subsection{Van visie naar 'plan plus contract'}

D e totstandkoming van $\mathrm{H}$ artslag L imburg is een continu groeiproces geweest waarvan alleen al de aanloop tot de daadwerkelijke start ruim drie jaar duurde (1994-1998). O m de opgedane ervaringen in dit opbouwproces te delen met anderen wordt beschreven hoe de verschillende elementen werden opgebouwd en hoe dit paste bij de belangen van de actoren, vertegenwoordigd in de zogenoemde 'Redactiecommissie' en Stuurgroep.

Partners in de Redactiecommissie waren vertegenwoordigers uit de praktijk (de $G G D$, huisarts) en de wetenschap (de U M via de capaciteitsgroepen Gezondheidsvoorlichting, $\mathrm{H}$ uisartsgeneeskunde en Beleid, Economie en $\mathrm{O}$ rganisatie van de Zorg en de afdeling ( ardiologie van het azM ). Beleidsmakers en bestuurders konden invloed uitoefenen via een bredere Stuurgroep waarin vertegenwoordigd: de directie van de GGD, een burgemeester, een wethouder (tevens bestuursvoorzitter van de GGD ) en een ambtenaar van het streekgewest.

\subsubsection{Onderzoek}

Vanuit de verwachting dat resultaatmeting op verschillende niveaus essentieel is voor alle betrokkenen, lag er voor de aanwezige universitaire vertegenwoordigers sinds 1996 een uitdaging om via onderzoek een belangrijke bijdrage aan het project te leveren. In de voorstellen werd gekozen voor effect- én procesonderzoek. O mwille van wetenschappelijke kwaliteitseisen werd gekozen voor gecontroleerde studies op drie niveaus: een controle regio elders in N ederland, controle huisartspraktijken binnen de regio en een randomised controlled trial op patiëntniveau in het ziekenhuis. Belangrijk argument voor deze keuzes was dat wetenschappelijke 'evidence' nodig was om zowel op professioneel als bestuurlijk niveau te kunnen streven naar continuering van deze gezamenlijke aanpak. H et daaruit voortvloeiende ethische dilemma voor de praktijk, die moet zien te schipperen tussen enerzijds vasthouden aan meetbare doelen en anderzijds ruimte geven voor lokale behoeften en kansen, is uitgebreid beschreven (H orstman \& H outepen, 2005).

Ten behoeve van de procesevaluaties werden alle te verwachten processtappen 
voor de opbouw en werkwijze van de interventies beschreven (Ruland, 1999a/b). $D$ e al jarenlang in M aastricht en D oetinchem lopende RIV M Peilstationsstudie bood een kans om met het Rijksinstituut voor Volksgezondheid \& M ilieu (RIV M ) een kosteneffectiviteitstudie te ontwerpen tegen relatief lage onderzoekskosten. Eind 1996 werden de onderzoeksvoorstellen door de $\mathrm{H}$ artstichting getoetst in een uitgebreid beoordelingstraject. Eind 1997 resulteerde een complex onderhandelingstraject in de honorering van vier promotiestudies, waarvan één gefinancierd door de U M. In 2001 werd aan dit pakket een studie naar ethische aspecten toegevoegd, in 2002 gevolgd door het onderhavige onderzoek naar bestuurlijke verankering van de samenwerking. Kort na de start van het project werd tevens een Wetenschappelijke Advies Raad geïnstalleerd met als doel het kritisch volgen van de kwaliteit van onderzoek en uitvoering.

\subsubsection{Praktijk}

Voor de GGD was H artslag Limburg de belangrijkste invulling van haar al vanaf 1989 aangekondigde 'integrale' preventiebeleid. In de loop van 1996 dreigde echter het draagvlak bij de gemeente $M$ aastricht voor het sinds 1991 ingezette buurtgerichte gezondheidsbeleid af te kalven, onder andere vanwege gebrek aan 'zichtbare' resultaten. $\mathrm{H}$ et nieuwe $\mathrm{H}$ artslag-plan bood de GGD een kans om de bestaande lokale werkgroepen in vier volksbuurten onder te brengen in een breder kader en zo een stevigere beleidsmatige basis te geven.

$0 \mathrm{~m}$ voldoende win-win met de bij het buurtwerk betrokken professionals en vrijwilligers te realiseren werd afgesproken dat vijftig procent van de inzet voor preventiethema's voeding, bewegen en niet-roken zou zijn en vijftig procent van de activiteiten vrije keus zou zijn. Bovendien werd het werkbudget voor buurtactiviteiten aanmerkelijk vergroot. $M$ et dit concept werd eerst de instemming van de buurtwerkgroepen en het $M$ aastrichtse welzijnswerk gewonnen, en vervolgens ook het welzijnswerk in de andere gemeenten. Besloten werd om in de randgemeenten te werken met werkgroepen op gemeentelijk i.p.v. buurtniveau. $0 \mathrm{~m}$ voldoende personele inzet van het welzijnswerk te garanderen werd afgesproken dat vijftig procent van de tijdsinvestering zou plaatsvinden uit de bestaande inzet; dit vanuit de argumentatie dat veel gezondheidsactiviteiten sociale activiteiten zijn en dus ook welzijnswinst opleveren. O nder de titel van een regionaal 'community'-project werd door de GGD voor het aanvullende deel van de welzijnsinzet medio 1997 extra financiering verkregen bij alle gemeenten.

Voor de huisartsen, vertegenwoordigd via de capaciteitsgroep H uisartsgeneeskunde en via een niet-geacademiseerde huisarts, werd ervan uitgegaan dat zij voordeel zouden ondervinden van de extra praktijkondersteuning die beschik- 
baar zou komen voor interventiepraktijken. Bovendien werd in het onderzoeksbudget een financiële tegemoetkoming opgenomen voor de extra tijdsinvestering van elke praktijk. D e interventie op de C ardiologie werd geïntegreerd in de huisartsgeneeskundige promotiestudie. W inst voor de C ardiologie lag in de aanstelling van twee parttime verpleegkundigen die de patiëntenbegeleiding gingen uitvoeren en tevens de cardiologen op dit punt zouden kunnen ontlasten.

\subsubsection{Beleid}

Voor de gemeenten betekende het $\mathrm{H}$ artslag Limburg initiatief een concrete invulling van lokaal gezondheidsbeleid, een taak beschreven in de Wet Collectieve Preventie Volksgezondheid (WCPV) en destijds slechts geformaliseerd als 'facultatief ' onderdeel van het door de gemeenteraad goedgekeurde GGD -beleid. Een schriftelijke intentieverklaring van de $\mathrm{H}$ artstichting betreffende haar financiële bijdrage aan zowel uitvoerings- als onderzoeksdelen van het project hielp om gemeenten te overtuigen om de inzet van GGD en welzijnswerk aanvullend te subsidiëren. Afgesproken werd dat de bijdrage van de $\mathrm{H}$ artstichting aan de uitvoeringskosten van het community-project na drie jaar zouden worden overgenomen door gemeenten. Streven was dat gemeenten hun bijdrage vanaf 2003 zouden continueren, afhankelijk van de uitkomsten van het onderzoek. Analoge afspraken werden gemaakt met de grootste zorgverzekeraar uit de regio, VGZ . In een brief zegde deze toe om bij voldoende procesresultaten de financiering van de uitvoering van de hoogrisico-interventie in de tweede projectperiode (2001-2003) serieus te zullen overwegen. Aan deze toezegging heeft VGZ zich ook gehouden.

$O$ mdat de gemeente $M$ aastricht aangaf onvoldoende eigen middelen te hebben voor de start van dit initiatief, werd besloten om de additionele personele inzet van het welzijnwerk deels te financieren via tijdelijke regelingen voor langdurig werkelozen. D aarnaast benutte de gemeente eveneens tijdelijke gelden uit het G rote Stedenbeleid (GSB). Voordeel van dit eerste was dat twee buurtbewoners via een betaalde functie deel konden nemen aan het project, wat gezien werd als een betekenisvol signaal naar de actie-buurten. Voordeel van opname in het GSB was het formaliseren van $\mathrm{H}$ artslag als onderdeel van actueel gemeentelijk beleid. 


\subsubsection{Netwerkmanagement als cement tussen praktijk, onderzoek en beleid}

$\mathrm{N}$ aast het ontwikkelen van complementaire elementen uit onderzoek, praktijk en beleid moest ook de samenhang daartussen bestendigd worden. In chronologisch volgorde betrof dit vanaf medio 1997 het realiseren van de belangrijkste subsidies van gemeenten en $\mathrm{H}$ artstichting, het sluiten vanuit de GGD als hoofdaannemer van formele contracten met alle betrokkenen, en activiteiten om draagvlak en participatie te vergroten. $\mathrm{H}$ et projectplan met daarin opgenomen de verdeling van taken en verantwoordelijkheden tussen alle partners vormde centraal onderdeel van die contracten. $0 \mathrm{~m}$ draagvlak te ontwikkelen buiten de kring van direct betrokkenen werd een brochure uitgebracht waarin via artikelen en interviews een wervend beeld neergezet werd van het nieuwe regionale initiatief. Tegelijkertijd werden via de 'sneeuwbal' methode interviews gehouden om vrijwilligers te werven voor lokale werkgroepen. $\mathrm{N}$ a een nulmeting begin 1998, kon op 10 juni van dat jaar $\mathrm{H}$ artslag Limburg officieel van start gaan.

$>$ De Nederlandse Hartstichting subsidieerde als hoofdsponsor de interventie en de bijbehorende evaluatieonderzoeken. Volgens de initiële planning zouden regionale partners deze bijdrage vanaf 2001 overnemen, als de samenwerking haalbaar en productief zou blijken te zijn. Begin 2000 gaven de gemeenten echter aan dat zij geen beschikking hadden over de benodigde gelden om de gezondheidswerkgroepen in stand te houden. Om wetenschappelijke resultaten te kunnen meten was continuering tot en met 2003 echter cruciaal. Allerlei pogingen werden in het werk gesteld om een oplossing te vinden. Dankzij inspanningen van bij het project betrokken ambtenaren deed zich in mei 2000 een kans voor: het project mocht gepresenteerd worden aan de premier en verschillende locale politici tijdens een werkbezoek. Dankzij eerdere wetenschappelijke contacten kon bij die gelegenheid tevens een aanbevelingsbrief van de WHO overhandigd worden. In oktober 2000, toen de gemeentelijke subsidie nog steeds onzeker was, wendde de projectleider zich tot de Nederlandse Hartstichting. Resultaat was dat de NHS zich in stilte garant stelde voor een bedrag groot genoeg om alle locale werkgroepen voor ruim een half jaar in stand te houden. Gesteund door deze garantie hielden projectleider en directeur van de GGD voet bij stuk richting de gemeenten, ook toen de deadline van 31 december 2000 allang verstreken was. Hartslag Limburg ging door, in maart 2001 geholpen door het winnen van de nationale Preffi-prijs en een internationale prijs van de WHO. Uiteindelijk, in de late zomer van 2001, stemden de gemeenten alsnog toe in aanvullende subsidie voor de periode 2001-2003. 
In de periode 2000-2001 bleek dat slechts met grote moeite de oorspronkelijk beoogde uitbreiding van de gemeentelijke financiële bijdrage voor de periode 2001-2003 gerealiseerd kon worden (zie tekstblok). D it overigens in tegenstelling tot de zorgverzekeraar die het parallelle hoogrisicodeel wel financieel adopteerde. G eleidelijk aan werd duidelijk hoe lastig het kan zijn om vanuit een GGD de strevingen uit praktijk en onderzoek over langere termijn te laten 'matchen' met de belangen vanuit het beleid. D eze ervaringen richtten de aandacht op de rol van bestuurders en de mogelijkheden en beperkingen van netwerkmanagement. D it resulteerde uiteindelijke in de hier voorliggende studie (Ruland et al., 2003).

\subsection{Discussie}

Een bespiegeling op de opbouwfase van $\mathrm{H}$ artslag Limburg werd ingeleid met de vraag: hoe is die samenwerking opgebouwd? W elke elementen kenmerken de infrastructuur en welke factoren hebben de totstandkoming bevorderd dan wel belemmerd?

In drieënhalf jaar voorbereidingstijd is een infrastructuur opgebouwd voor de periode 1998-2003 waarin werd voorzien in een uitgebreide samenwerking tussen praktijk, onderzoek en beleid. Kenmerken uit het $\mathrm{O}$ ttawa $\mathrm{C}$ harter, te weten participatie van lokale gemeenschappen (lokale werkgroepen), supportive environments (via te ondernemen interventies), advocacy (op basis van de opgebouwde coalitie) en een heroriëntatie van gezondheidsinstellingen (meer aandacht voor gezond gedrag) kregen in deze structuur een plaats. Kenmerkend voor het opbouwtraject was de stapsgewijze groei, zoveel mogelijk in aansluiting op bestaande situaties. Kenmerk van de praktijk betrof de integratie van preventie in nulde, eerste en tweede lijn. Kenmerk van het onderzoek betrof het type onderzoek: via proces-, effect- en kosteneffectiviteit. Kenmerk van de component beleid betrof de participatie van zowel bestuurders als ambtenaren, zij het op enige afstand van de professionals uit praktijk en wetenschap. Kenmerkend, tenslotte, voor het cement tussen praktijk, onderzoek en beleid was de regierol, c.q. het netwerkmanagement vanuit de GGD. Realisatie van al deze kenmerken in één infrastructuur was voor de W H O reden om H artslag Limburg te erkennen als veel belovend samenwerkingsmodel (Boelen, 2000a/b; Lippeveld \& G lasser, 2003).

U it de beschrijving van het opbouwtraject van $\mathrm{H}$ artslag Limburg komt een aantal bevorderende en belemmerende factoren naar voren. Een eerste bespreking daarvan volgt hieronder. In de latere hoofdstukken wordt de visie op deze factoren verder uitgewerkt. 
$0 \mathrm{~m}$ te beginnen telt het grote aantal partijen als een belemmerende factor. Een van de conclusies uit de casus 'W ijkgericht werken in Rotterdam' luidt: "D e belangentegenstellingen van de vele belanghebbenden in zo'n groot project zijn vaak moeilijk overbrugbaar." (de H aes, 2002). D e beschrijving van de opbouw van $\mathrm{H}$ artslag Limburg laat inderdaad zien hoe divers de belangen lagen, en hoeveel tijd het kostte om ze te overbruggen via een stapsgewijze opbouw. In elke stap werd met elke partner gezocht naar voldoende 'win-win' en getracht werd om de al opgebouwde coalitie te benutten als argument voor derden om óók mee te doen.

Twee bevorderende factoren waren cruciaal: zonder de financiële mogelijkheden van de (hoofd)sponsoren, de N ederlandse $\mathrm{H}$ artstichting, ZonM w en het G rote Steden Beleid, was er geen $\mathrm{H}$ artslag Limburg geweest. D e timing, ten tijde van een voor gemeenten positief economisch klimaat, was gunstig. Beide factoren droegen bij aan het overwinnen van de belemmerende factor dat er voor gemeenten geen helder beleidskader en dus een relatief gering belang lag. Verder werkte de lokale context merendeels bevorderlijk: door eerdere samenwerking tussen partners bestond er al een vertrouwensbasis. De persoonlijke inzet van een gedreven bestuurder in een unieke sleutelpositie (burgemeester en bestuurlid bij de $\mathrm{H}$ artstichting) heeft bevorderlijk gewerkt op het draagvlak bij politiek en bestuurlijk indirect betrokkenen. $\mathrm{H}$ iermee werd een belangrijke belemmerende factor uit de Rotterdamse casus, namelijk de discontinuïteit in bestuurlijk draagvlak, overwonnen (de H aes et al., 2002; Voorham et al., 2002). $D$ it illustreert tevens hoe belemmerende factoren het spiegelbeeld van bevorderende factoren vormen.

$M$ et het benoemen van bevorderende en belemmerende factoren rijst ook de vraag in hoeverre dit soort factoren al eerder beschreven zijn. D e stapsgewijze opbouw van het project met oog voor actuele belangen van alle actoren vertoont opvallende overeenkomsten met zowel het model van Kingdon (1995) als het zogenoemde W IZ-model, genoemd naar de Werkgroep Integrale Zorg van de U M (van Raak et al., 1999). Kingdon onderscheidt drie typen van belangengroepen: probleemhouders (de community, professionals), probleemoplossers (professionals) en beslissers (politici). Volgens Kingdon ontstaat er een 'window of opportunity' wanneer de drie stromen bij elkaar gebracht kunnen worden. Wanneer dit door een partij op actieve en creatieve wijze wordt gedaan spreekt Kingdon van sociaal ondernemerschap (in $\mathrm{H}$ artslag Limburg: door de burgemeester en de GGD ).

Waar Kingdon de totstandkoming van politieke besluitvorming beschrijft, reikte de opbouw van $\mathrm{H}$ artslag Limburg echter verder, namelijk tot en met de uitvoe ring van de samenwerking. Kingdon focust op de betrokken actoren en het benodigde sociaal ondernemerschap, maar spreekt zich nauwelijks uit over bijkomende belemmerende of bevorderende factoren. $D$ at laatste spoort beter met 
rangschikking van bevorderende en belemmerende factoren voor inter-organisationele samenwerking van het WIZ-model. H et W IZ-model onderscheidt externe factoren, lokale context, management en draagvlak. Combinatie van beide modellen heeft geleid tot de ontwikkeling van een aangepast W IZ-model (Ruland et al., 2003). Belangrijke toevoeging betreft de uitbreiding van het concept sociaal ondernemerschap tot een bredere dimensie van procesmanagement, verandermanagement genoemd, als specifiek onderdeel van netwerkmanagement. In het volgende hoofdstuk wordt daar verder op ingegaan.

$\mathrm{O} p$ basis van de ervaringen in $\mathrm{H}$ artslag Limburg wordt geconcludeerd dat de beschikbaarheid van adequaat netwerkmanagement, met oog voor zowel project- als verandermanagement, een belangrijke bevorderende factor is. Tot slot kunnen we concluderen dat in $\mathrm{H}$ artslag Limburg het opbouwen van een integrale samenwerking, in lijn met de aanbevelingen van het $C$ harter van O ttawa en de Volksgezondheid Toekomst Verkenning 2002, haal baar bleek. Terugkijkend kunnen aspecten als externe sponsoring, bestuurlijk draagvlak, eerdere samenwerkingshistorie en netwerkmanagement geduid worden als belangrijke bevorderende factoren. Eén aspect valt daarbij nog op te merken: hoewel blijvende samenwerking al in 1995 als tweede doelstelling werd geformuleerd, ontbrak destijds bij het projectteam van GGD en U M een heldere visie over de weg langs welke deze doelstelling gerealiseerd kon worden en over de barrières die daarbij verwacht konden worden. Pas vanaf 2000 begon het belang van het bestuurlijk niveau door te dringen. Een vanuit onderzoek nog weinig belicht aandachtsgebied waar belangrijke lessen te leren zijn.

\section{Noot}

a) De vaste kern van de Redactiecommissie bestond uit de auteurs van dit artikel, aangevuld met Wim Ritzen, huisarts, prof.dr. Evelien de Leeuw en prof.dr. Foppe ten Hoor †. De Redactiecommissie rapporteerde aan de bredere Stuurgroep, waarin tevens vertegenwoordigd de lokale bestuurders. 


\section{Hoofdstuk 3 Onderzoeksopzet}

\subsection{Inleiding}

In het vorige hoofdstuk is aangegeven hoe de samenwerkende partners van $\mathrm{H}$ artslag Limburg er in slaagden om een regionale infrastructuur op te bouwen. Beschreven is dat volgens planning werd beoogd dat in de tweede driejarige projectfase (2001 t/m 2003) gemeenten en zorgverzekeraar een grotere financiële bijdrage aan de uitvoering zouden gaan geven, en hoe moeizaam dit traject verliep wat betreft de gemeentelijke bijdragen (paragraaf 2.5.4). Reflectie op deze ervaring riep de behoefte op onderzoek te realiseren bij de volgende overgangsfase van het project. Als eerste stap werd gezocht naar een theoretisch model (paragraaf 2.7). In dit hoofdstuk wordt beschreven welk model uiteindelijk werd geconstrueerd (paragraaf 3.2). Vervolgens komt aan bod hoe de centrale vraagstelling aan de hand van het model is uitgewerkt in deelvragen (paragraaf 3.3). D aarna gaat paragraaf 3.4 uitgebreid in op de methode van onderzoek waaronder de valideringstrategie. De validering met behulp van een onafhankelijk expertpanel heeft geleid tot een waardevolle bijstelling van het model (paragraaf 3.5).

\subsection{Het WIZ-model}

\subsubsection{De ontwikkeling van het model}

Eerste stap in de opzet van deze studie naar verankering van samenwerking was de ontwikkeling van een passend conceptueel kader. D it model is ontwikkeld op basis van een eerder model van de capaciteitsgroep BEO Z van de U M dat in meerdere studies naar samenwerking in de zorg is gebruikt (van Raak et al., 1999; M ur-Veeman et al., 1994). D it basismodel onderscheidt vier dimensies, of clusters van factoren, die invloed hebben op het realiseren van samenwerking (zie figuur 3.1). M anagement, bestaand uit het projectplan en de projectorganisatie, moet leiden tot de gewenste resultaten van samenwerking, maar wordt beïnvloed door externe factoren, de lokale context en de mate van draagvlak. H et model komt voort uit traditie van de open systeem theorie (Scott, 1992) waarin de dimensies van factoren elkaar wederzijds beïnvloeden (zgn. cybernetisch systeem).

D e dimensie externe factoren bestaat uit twee deelfactoren: 'overheidsbeleid' (met name beleidsnota's, wet- en regelgeving) en 'beleid van financiers' (mate waarin zij zich ondersteunend opstellen). D e dimensie lokale context is opge- 


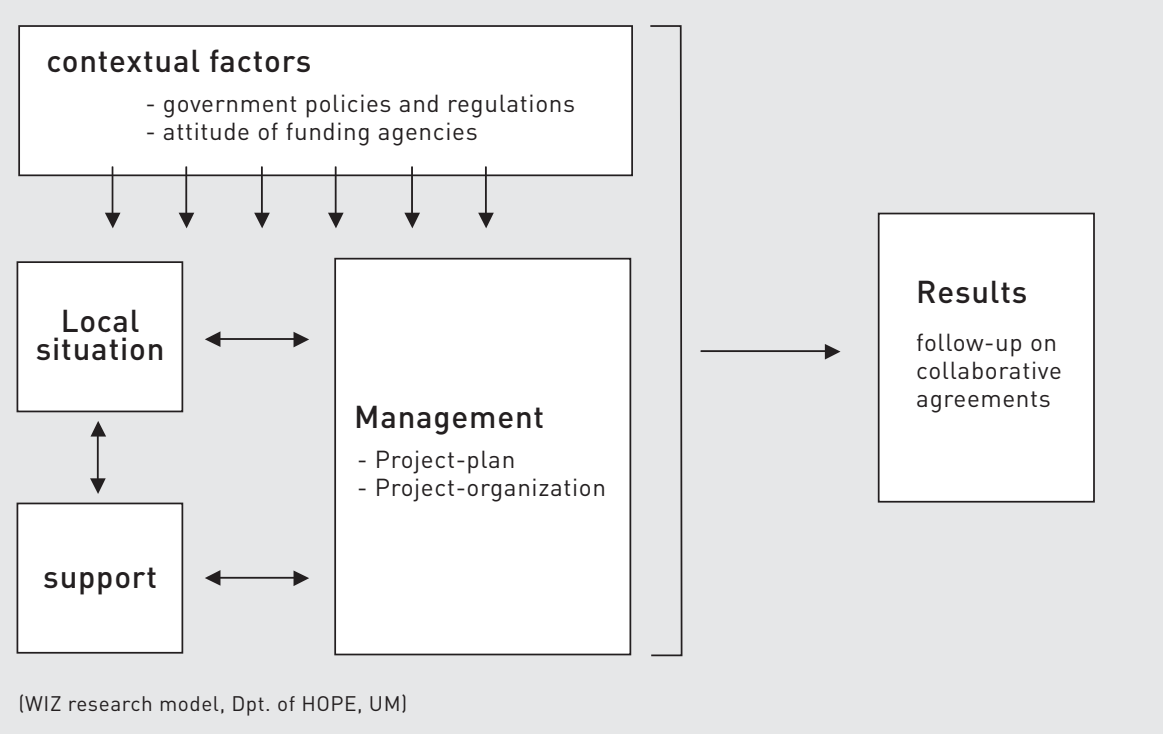

Figuur 3.1 Onderzoeksmodel voor studies naar samenwerking in de zorg; Werkgroep Integrale Zorg (WIZ), capaciteitsgroep BEOZ, UM

bouwd uit de factoren 'bestaande samenwerkingsrelaties' (de mate waarin al onderling vertrouwen is opgebouwd) en 'kenmerken van bedrijfsvoering' (financiële tekorten, personele problemen, reorganisatie, e.d.). D e dimensie draagvlak bestaat uit twee clusters van factoren. Enerzijds variabelen die van invloed zijn op de mate van draagvlak: onder andere de keuze van de gemeenschappelijke doelstelling, het oordeel over dit doel in vergelijking tot de overige eigen doelen (het belang), het voordeel van de samenwerking voor de eigen organisatie (winwin situatie) en domeinconsensus (overeenstemming tussen actoren over de complementariteit van ieders taken en werkwijze). En anderzijds in de variabelen die uiting geven aan het draagvlak: onderling vertrouwen, betrokkenheid (gezamenlijke initiatieven, nakomen van afspraken), adaptatie (realiseren van interne aanpassingen ten gunste van de samenwerking).

Van deze drie dimensies, externe factoren, lokale context en draagvlak, is in eerder onderzoek aangetoond dat zij passen in de setting van de integrale zorg (cure en care) (van Raak et al., 1999; M ur-Veeman et al., 1994). Vanuit deze positieve ervaring is het aannemelijk om deze dimensies ook geldend te laten zijn in een model voor de publieke gezondheidszorg.

D e setting van dit onderzoek, publieke gezondheidszorg, verschilt echter ook op een aantal belangrijke punten met de curatieve sector. Eén van die verschillen betreft de factor tijd. Typerend voor preventie is dat de tijdsspanne tussen de 
interventie en de beoogde uitkomst veel groter is dan de tijdsspanne die acceptabel is in klinische studies en in politieke evaluaties. Een tweede factor betreft het aantonen van resultaat: evidence. $H$ et aantonen van effecten en kosten-effectiviteit binnen de publieke gezondheid is veelal zeer moeilijk. Ten derde laten de ervaringen in $\mathrm{H}$ artslag Limburg in de periode 2000-2001 zien dat succesvolle samenwerking op operationeel niveau nog niet onmiddellijk hoeft te leiden tot draagvlak op bestuurlijk niveau, zeker als betekenisvolle uitkomsten in termen van gezondheidswinst nog afgewacht moeten worden (zie paragraaf 2.5.4). Aanvullende actie is nodig om bestuurlijk draagvlak te verwerven, juist omdat het gaat om een onderwerp waarbij het niet mogelijk is om op korte termijn harde resultaten te tonen. D eze inzichten hebben geleid tot een aantal aanpassingen van het model. Duidelijk werd dat er meer gefocust moest worden op het bestuurlijke niveau, en dat de dimensie management niet zozeer het projectplan en de projectorganisatie moest betreffen als wel de factoren die invloed hebben op het bestuurlijke niveau.

O $p$ basis van literatuur uit de organisatieleer en beleidswetenschappen en de ervaringen uit het project $\mathrm{H}$ artslag Limburg, is een model ontwikkeld dat is weergegeven in figuur 3.2. $M$ et name de elementen binnen het cluster verandermanagement zijn 'experience-based': gebaseerd op de gesystematiseerde samenwerkingservaringen binnen het project $\mathrm{H}$ artslag Limburg over de periode 1994 - 2001.

Vertrekpunt van dit model is de notie dat een samenwerkingsinitiatief alleen gecontinueerd kan worden als daartoe ook op bestuurlijk niveau besluiten over genomen worden. Conform dit model kan tijdelijke samenwerking zich in de loop van de tijd onder invloed van een aantal factoren ontwikkelen tot een vorm van samenwerking die al dan niet sterker bestuurlijk verankerd is. Begin en eindpunt van het onderzoek vormt het niveau van bestuurlijke verankering, blok 0 en 6 in de figuur. Bestuurlijke verankering is gedefinieerd als samenwerking die gekenmerkt wordt door expliciete afspraken op vier aspecten, te weten: formalisatiegraad, duurzaamheid, inzet van middelen en reikwijdte. D e factoren die van invloed zijn op dit proces zijn gerangschikt in vijf clusters of dimensies, te weten: lokale context, externe factoren, verandermanagement, determinanten van draagvlak en uitingsvormen van draagvlak.

D e dimensies 'lokale context' (bestaande partijen en hun relaties) en 'externe factoren' (m.n. wet- en regelgeving, de opstelling van externe financiers) zijn in het algemeen relatief moeilijk beïnvloedbaar. Zij vormen de context waarbinnen, door middel van verandermanagement, draagvlak voor verdere bestuurlijke verankering bij de samenwerkende actoren versterkt moet worden. 


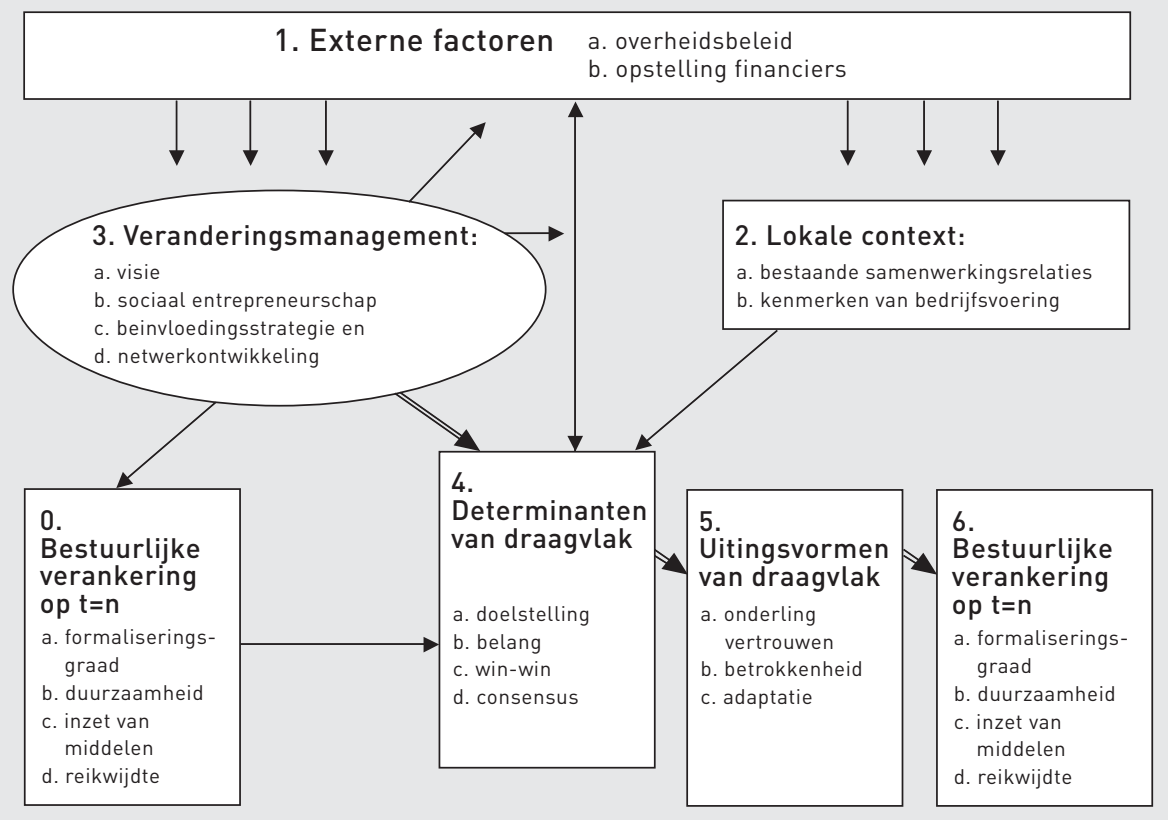

(WIZ research model, Dpt. of HOPE, UM)

Figuur 3.2 Het 'WIZ-model voor bestuurlijke verankering van samenwerking tussen de GGD en haar omgeving' bij de start van dit onderzoek.

In tegenstelling tot het oorspronkelijke systeemtheoretische model, is in het nieuwe onderzoeksmodel bewust voor gekozen om richting te geven aan de relatie tussen 'verandermanagement', dat via 'draagvlak', wil leiden tot 'bestuurlijke verankering'. Reden hiervoor is dat juist deze relatie handvaten biedt om de waarde te onderzoeken van praktische managementadviezen voor de GGD . Steun wordt hiervoor gevonden in de complexiteitstheorieën. In tegenstelling tot de open systeem theorie (die de wederzijds beïnvloeding voorop stelt) biedt het denken vanuit de complexiteitstheorieen juist aangrijpingspunten voor sturing. Vanuit deze theorie wordt benadrukt dat er mogelijkheden zijn om de richting te beïnvloeden waarin actoren en het systeem hun gedrag ontwikkelen. "Simply understanding system attractors is not always sufficient to bring about change. For systems to change they generally require tension for change. C areful sharing of meaningful information that touches natural attractors or creates new ones can lead those within the system to feel they must change." (PIsek \& $W$ ilson, 2001). D eze invalshoek laat zelfs open dat verandermanagement zich er ook op kan richten om via externe factoren (verandering overheidsbeleid) het lokale draagvlak te bevorderen. 
D e belangrijkste vernieuwing van dit model ligt in de uitwerking van de dimensie 'management'. In de organisatieliteratuur wordt frequent de nadruk bij veranderingsprocessen gelegd op de noodzakelijke combinatie van projectmanagement én verandermanagement. Projectmanagement betreft dan de inhoudelijke en beheersmatige kant: het realiseren van een organisatiestructuur, een plan van aanpak en de inzet van adequaat leiderschap (sturen en bewaken).

Verandermanagement richt zich op het noodzakelijke veranderproces: hoe reageren mensen op verandering, wat is nodig om dit te sturen (omgaan met weerstand, draagvlak bouwen, effectief communiceren, et cetera). Beide aspecten van management zijn essentieel voor samenwerking en complementair. Gezien het accent in deze versie van het W IZ-model op het creëren van bestuurlijke verankering in de public health, moet binnen de dimensie management het accent liggen op verandermanagement. Verandermanagement betreft hier de interventies die vanuit de centrale actor (in de $\mathrm{H}$ artslag Limburg casus de G GD , cq. het projectteam) ondernomen worden om het draagvlak voor samenwerking te vergroten binnen het openbaar bestuur en de zorgsector.

Een gedetailleerde beschrijving van de veronderstellingen waarop de dimensies en factoren zijn gebaseerd en de indicatoren (definities) waarmee het vóórkomen van de deelfactoren in de verzamel de data is beoordeeld, is opgenomen in bijlage 1.

\subsubsection{De dimensie verandermanagement, specifiek in de publieke gezondheidszorg}

Een voor de hand liggende benadering voor het invullen van de dimensie verandermanagement is om te kijken naar modellen voor geplande verandering (Cummings \& Worley, 1997; D uncan et al., 1998; Boonstra et al., 1998; M organ, 1986). Toch kunnen deze modellen niet klakkeloos gekopieerd worden. De meeste literatuur over verandermanagement komt namelijk voort uit onderzoek naar organisatieontwikkeling binnen zelfstandige organisaties. De publieke gezondheidszorg verschilt echter op drie belangrijke punten van de setting van een zelfstandige organisatie.

Ten eerste brengt het realiseren van samenwerking tussen organisaties een extra laag van complexiteit met zich mee in vergelijking tot een verandertraject binnen een organisatie.

Ten tweede ontbreekt in de publieke gezondheidszorg een heldere structuur. $\mathrm{H}$ et veld wordt gekenmerkt door een verzameling stakeholders uit verschillende sectoren en gremia, zowel politiek als professioneel, die met elkaar moeten samenwerken in een arena zonder eenduidige gezagsstructuur. Besluitvorming vindt plaats in een verspreid aantal semi-hiërarchische systemen van individuele 
zorgprofessionals tot overheidsorganen. $M$ et als gevolg dat een verandermanager in deze setting veel minder sturingsinstrumenten heeft dan in een zelfstandige organisatie.

Ten derde lijkt in de publieke gezondheidszorg de kloof tussen het operationele niveau en het bestuurlijke niveau, als gevolg van de versnippering en de complexe besluitvormingsprocessen, veel groter dan in een zelfstandige organisatie. D eze drie punten maken het minder waarschijnlijk dat erkende modellen voor verandermanagement één op één toepasbaar zijn in de publieke gezondheidszorg. Een illustratie daarvan vormt de casus $\mathrm{H}$ artslag Limburg in de periode 1998-2001 (zie paragraaf 2.5.4). In deze casus werden alle stappen uit de aanbevolen handboeken ondernomen: "kies een positief onderwerp, verzamel positieve ervaringen met brede participatie, onderzoek data en ontwikkel voorstellen, ontwikkel een visie met breed draagvlak, ontwikkel actieplannen, voer ze uit, monitor en evalueer de voortgang, en verspreid en bespreek de gevonden resultaten." (Cummings \& Worley, 1997). Toch bleken al deze acties in eerste instantie nog niet voldoende om bestuurlijk akkoord voor continuering van $\mathrm{H}$ artslag Limburg te verkrijgen. Wat daar in meegespeeld kan hebben is de hierboven beschreven kloof tussen het operationele en bestuurlijke niveau in de publieke gezondheidszorg. Conventionele veranderstrategieën zijn adequaat in het bereiken van het operationele niveau, maar bereiken wellicht het bestuurlijk niveau onvoldoende. Tegelijkertijd kunnen concurrerende belangen het draagvlak op het bestuurlijk niveau doen verminderen.

Bovenstaande overweging heeft geleid tot de vraag of uit andere vakgebieden geen aanvullende modellen betrokken konden worden. Gegeven de twee belangrijke kenmerken, complexiteit en afwezigheid van een gezagsstructuur, kwamen daarbij twee onderzoeksvelden naar voren: management van beleidsnetwerken in de publieke gezondheidszorg, en de theorieën over 'complex adaptive systems'. H et veld van de beleidsnetwerken is passend vanwege de overeenkomst met een relatief ongestructureerde arena waarin ideeën strijden om de aandacht van beleidsmakers en politici (Kingdon, 1995). Kingdon's concept van sociaal ondernemerschap lijkt goed te passen bij de ervaringen van $\mathrm{H}$ artslag L imburg waarin probleemhouders, probleemoplossers en beslissers stap voor stap bij elkaar gebracht werden om een 'window of opportunity' te creëren (zie hoofdstuk 2). D e theorie van de 'complex adaptive systems' beschrijft een visie op management en leiderschap die voortkomt uit de karakteristieken van dit soort systemen: niet-lineaire relaties, onvoorspelbaarheid, en de aanwezigheid van herkenbare gedragspatronen van complexe systemen (PIsek \& Greenhalgh, 2001). Beide onderzoeksvelden bieden concepten die goed lijken aan te sluiten bij de praktijk van de publieke gezondheidszorg. Tegelijkertijd is het lastig om te beargumenteren welke mix van elementen uit de genoemde drie onderzoeksvelden nu het beste zal passen op de onderzoeksvraag van deze studie. Uiteindelijk is 
daarom vrij pragmatisch gekozen voor vier elementen die goed passen bij de eerdere ervaringen in $\mathrm{H}$ artslag Limburg en tevens passen in een onderlinge, chronologische volgorde. D e gekozen elementen zijn: visie, sociaal ondernemerschap, bënvloedingstrategi eën en netwerkontwikkeling. De chronologische samenhang zou als volgt werken: het fundament wordt gelegd door de visie (of een begin daarvan). Sociaal ondernemerschap koppelt die visie aan mensen en organisaties. $D$ it genereert kansen, door beïnvloedingsstrategieën worden kansen vergroot en benut. Eenmaal op gang kan het netwerk zichzelf versterken, de inbouw van brugfuncties (linkage, ofwel "building a support system for change agents" (Cummings \& Worley, 1997) bestendigt dit proces.

\subsubsection{Factoren binnen de dimensie verandermanagement}

Visie

Verandermanagement vereist visie. H eel algemeen gesproken beschrijft de visie de gewenste toekomst waar de verandering zich op moet richten (Cummings \& Worley, 1997). Visie is een basiselement in alle drie de onderzoeksvelden (PIsek \& W ilson, 2001; Cummings \& Worley, 1997; Kingdon, 1995). O m draagvlak te realiseren dient de manager allereerst een visie uit te dragen die bestuurlijke stakeholders overtuigt. $D$ e visie betreft het formuleren van het 'hoe, wat en waarom': het gemeenschappelijke doel, de weg waarlangs dit doel bereikt kan worden (onder andere ook ieders rol daarin en de 'win-win' daarin) en vooral het belang van deze benadering in vergelijking tot mogelijke alternatieven.

Essentieel hierbij is kennis bij de manager over parallelle en concurrerende belangen onder de andere actoren. 0 pmerkelijk is dat, in tegenstelling tot planningsmodellen die uitgaan van het SM ART formuleren van doelen, door de complexiteitstheorie wordt beargumenteerd dat een visie voldoende globaal moet zijn om de creativiteit te genereren die nodig is voor het bereiken van een moeilijk haalbaar doel. Zo'n visie zou beperkt moeten blijven tot het 'aangeven van de richting' en het 'bepalen van grenzen' (PIsek \& W ilson, 2001). D it sluit aan bij de conclusie van een studie naar de ethische aspecten van gezondheidsbevordering in $\mathrm{H}$ artslag Limburg. In deze studie wordt er namelijk voor gepleit om het heersende rationalistische sturingsparadigma in te ruilen voor een pragmatisch, op leren gericht paradigma (H orstman \& H outepen, 2005, pagina 213).

\section{Sociaal ondernemerschap}

$\mathrm{N}$ ieuw beleid ('a window of opportunity') komt tot stand doordat de ideeen en capaciteiten van probleemhouders, oplossingvinders en beslissers op het juiste moment bij elkaar gebracht worden; degene die deze groepen aan elkaar knoopt wordt betiteld als sociaal ondernemer ('entrepreneur' (Kingdon, 1995)). De 
sociaal ondernemer identificeert zichtbare en (nog) onzichtbare actoren in dit proces en lobbyt voor kansrijke alternatieven. Bruikbare technieken zijn: netwerkontwikkeling, confereren, communiceren via 'top-down', 'bottum-up', 'middle up\& down', 'inside out' en 'outside in' methodes (Boonstra et al., 1998). In $\mathrm{H}$ artslag Limburg zijn deze communicatiemethoden bijna allemaal toegepast. 'Bottum-up' door het geven van een stem aan lokale organisaties en buurtbewoners via wijkbladen, miniconferenties en deelname aan werkgroepen; 'middle up\& down' via het verspreiden van nieuwsbrieven, 'inside out' door te streven naar (inter)nationale erkenning, en 'outside in' door het benutten van een werkbezoek van de minister-president (zie paragraaf 2.5.4).

Passend bij het concept van de sociale entrepreneur benadrukt de complexiteitstheorie de behoefte aan leiderschap dat het managementniveau van sturing en controle weet te overstijgen en middels het realiseren van een coalitie nieuwe wegen durft in te slaan (PIsek \& W ilson, 2001).

\section{Beïnvloedingsstrategieën}

D raagvlak voor samenwerking kan versterkt worden door beïnvloedingsstrategieën: machtsstrategi eën, positieve feedback en imago ontwikkeling. M achtsstrategieën betreffen het identificeren van actoren, hun belangen en hun positie (voorstander, tegenstander of neutraal), coalitievorming (het overtuigen van neutralen en het neutraliseren van mogelijke tegenstanders) en de inzet van geld of andere 'incentives'. In H artslag Limburg was de aanwezigheid van een meerderheid van partners uit zorg en welzijnssector belangrijk om portefeuillehouders van gemeenten te overtuigen van een breed maatschappelijk draagvlak. Recent inzicht uit onderzoek naar het managen van complexe systemen suggereert dat het proberen om weerstand tegen verandering te overwinnen, minder effectief is dan gedacht. $M$ eer effect wordt verwacht van het begrijpen wat verandering attractief zou kunnen maken en het delen van de noodzaak tot verandering (Plsek \& Wilson, 2001).

H oewel machtsstrategieën relevant zijn, zal de keus voor een gezamenlijke aanpak uiteindelijk gebaseerd moeten zijn op positieve resultaten. Als eindresultaten lang op zich laten wachten of in eerste instantie teleurstellen, is het cruciaal zijn om andere vormen van vooruitgang te demonstreren. Communicatie van vooruitgang en successen (positieve feedback) dient gecombineerd te worden met de opbouw van een positief imago via massamediale uitingen. Voor het werven van nieuw draagvlak is een positieve beeldvorming namelijk een vereiste. "Sociale systemen en organisaties worden niet gedreven door een gemeenschappelijk doel, maar veeleer door het streven naar behoud of creatie van een eigen identiteit. Wil men een systeem veranderen dan dient men zich derhalve niet uitsluitend te focussen op het veranderen van doelstellingen; beter is het om het gevoel voor identiteit te beïnvloeden." (M organ, 1993). Beeldvorming is echter 
niet gemakkelijk te verbeteren, het vergt een lange-termijnstrategie, waarbij het noodzakelijk is dat alle uitingen consistent en duidelijk zijn. Beeldvorming wordt slechts voor een klein deel bepaald door persoonlijke contacten; vooral hetgeen in de media naar voren komt is van groot belang voor de algemene beeldvorming.

\section{Netwerkontwikkeling}

D e toepassing van verandermanagement vereist actuele en informele informatie vanuit verschillende lagen binnen organisaties. G een manager kan echter overal tegelijk aanwezig zijn. N odig is dus de opbouw van een voldoende groot netwerk met daarin opgenomen 'bruggenhoofden' die de toegang garanderen tot deze informatie. Dit is van belang om keuzes te maken tussen welke acties ingezet moeten worden, en vooral: wanneer. D ankzij de aanwezigheid van deze brugfuncties (linkage) kunnen barrières tussen organisaties geslecht worden. Voorbeelden hiervan in het $\mathrm{H}$ artslag Limburg project zijn de getrainde verpleegkundigen ('gezondheidsadviseurs') die vanuit het project in huisartsenpraktijken en in het ziekenhuis werken, en de welzijnswerkers en gemeente ambtenaren die samen met GVO 'ers van de GGD de lokale werkgroepen leiden. D e inbouw van deze functies, contractueel vastgelegd in samenwerkingsovereenkomsten, is voor het $\mathrm{H}$ artslag Limburg van vitaal belang gebleken; niet alleen voor de projectuitvoering, maar vooral voor het creëren van een structuur (support system) voor communicatie en samenwerking.

\subsubsection{Conclusie}

Centraal in dit onderzoek staat de vraag hoe verandermanagement vanuit de GGD draagvlak onder bestuurders voor public health kan bevorderen. Inzicht in de factoren die van invloed zijn op dat draagvlak is dan belangrijk. Vanuit die behoefte is het hierboven gepresenteerde 'W IZ-model voor verandermanagement in de openbare gezondheidszorg' ontwikkeld. Een model dat enerzijds leunt op bestaande management literatuur en anderzijds voortkomt uit de praktijk van de 'new public health'. D e belangrijkste aanpassing ten opzichte van eerdere varianten van het WIZ-model betreft de invulling van de dimensie verandermanagement met vier factoren, en de richting van de pijlen; dit laatste verbeeldt de veronderstelling dat middels verandermanagement het draagvlak versterkt kan worden.

$\mathrm{N}$ aast de functie als onderzoeksmodel is de verwachting dat het model ook bruikbaar is voor de praktijk. D e bruikbaarheid voor de 'veranderaar' betreft vooral het overzicht dat het model biedt om te reflecteren op de eigen samen- 
werkingssituatie. Alle relevante gebeurtenissen kunnen een plaats krijgen, zwakke plekken kunnen herkend worden, keuzes voor het eigen handelen kunnen vooraf worden afgewogen en achteraf op systematische wijze geëvalueerd worden. $0 p$ deze manier kan het model benut worden als een checklist voor de kans op verankering van bestuurlijke samenwerking. $H$ et model, en daaruit verder ontwikkelde varianten, is inmiddels in verschillende onderzoeken benut (Ruland et al., 2003; Lippeveld \& G lasser, 2003; Leurs et al., 2002 en 2003).

\subsection{Uitwerking van de vraagstelling}

D e centrale vraagstelling van dit onderzoek luidt:

$0 p$ welke manier en in hoeverre kan verandermanagement vanuit de GGD, gege ven de context van lokale omstandigheden en externe factoren, bijdragen aan bestuurlijke verankering van regi onale samenwerking in de publieke gezondheidszorg?

O $\mathrm{m}$ de dataverzameling en analyse voldoende richting te geven, is deze vraagstelling uitgewerkt in de volgende deelvragen:

1. Welke elementen van verandermanagement worden er vanuit de GGD toegepast?

2. In hoeverre vindt er in de loop van de tijd daadwerkelijk bestuurlijke verankering plaats?

3. In hoeverre zijn er in de loop van de tijd veranderingen opgetreden in de lokale context en in externe factoren?

4. In hoeverre zijn er in de loop van de tijd veranderingen opgetreden in het draagvlak binnen het openbaar bestuur en in de zorgsector?

5. In hoeverre bestaat er een relatie tussen het toegepaste veranderingsmanagement en de mate van veranderingen in draagvlak?

6. Welke factoren binnen de dimensie draagvlak zijn voor bestuurlijke actoren in het openbaar bestuur en echelons van de zorgsector, de belangrijkste factoren ten aanzien van verankering van samenwerking?

7. In hoeverre bestaat er een relatie tussen de verandering in draagvlak en de mate van bestuurlijke verankering van de samenwerking?

8. Welke conclusies kunnen getrokken worden ten aanzien van de bruikbaarheid van elementen van verandermanagement voor het realiseren van draagvlak voor bestuurlijke verankering van samenwerking? 


\subsection{Methode}

\subsubsection{Onderzoeksopzet}

D eze studie is opgezet als een zogenoemde 'embedded' single case study (Yin, 1994). D eze aanpak is zowel beschrijvend als verklarend en maakt gebruik van zowel kwalitatieve als kwantitatieve data. D e 'single case' betreft de casus $\mathrm{H}$ artslag Limburg, de term 'embedded' verwijst naar het insluiten van meerdere niveaus van analyse.

Een case studie richt haar vraagstelling op het hoe en waarom van het object van studie. Typerend is dat de onderzoeker geen controle heeft over de gebeurtenissen en de context waarin die plaatsvinden; vaak is ook de afbakening tussen gebeurtenis en context onscherp. Wel kan de onderzoeker deelnemen aan de gebeurtenissen, deze beïnvloeden en van dichtbij observeren wat er plaats vindt. In paragraaf 3.4.3 wordt daar verder op ingegaan.

Een single case studie is geëigend wanneer er iets diepgaand onderzocht kan worden wat voorheen amper wetenschappelijk toegankelijk was. In zo'n geval kan alleen de beschrijving zelf al veel onthullen. Yin (1994) spreekt hier van de 'revelatory single case'.

D e opzet van deze studie is niet alleen beschrijvend maar ook verklarend ten aanzien van het onderzoeksobject. Yin (1994) onderscheidt single case studies in 'holistisch' (één enkele unit van analyse) en 'embedded' (multiple analyse niveaus). In deze studie is object van studie de samenwerking van organisaties, waarbij gebeurtenissen en meningen op meerdere niveaus onderzocht worden: geografisch (lokaal, regionaal, landelijk), verschillende doelgroepen (vijf gemeenten, GGD , ziekenhuis e.a.) en interactieniveaus (bestuursvergaderingen, management-overleggen, individuele interviews en enquêtes). D eze brede benadering heeft tot doel om enkelvoudige gebeurtenissen te kunnen plaatsen in hun bredere context en aldus nieuwe inzichten of verklaringen te genereren, in relatie tot de vraagstelling. $D$ oel is dus primair het beter begrijpen van de onderzochte problematiek, veelal stapsgewijs ('explanation building'). D eze werkwijze kan tevens leiden tot nieuwe theoretische inzichten, maar dit laatste staat niet voorop. Voor de ordening van data, de analyse op multiple niveaus en het zoeken naar verklaringen wordt het WIZ-model gebruikt, waarbij tevens kritisch gekeken wordt naar de mate waarin dit model als valide gekenmerkt mag worden (zie paragraaf 3.4.3 e.v.). D e studie heeft een kwalitatief karakter, met een beperkte kwantitatieve aanvulling via schriftelijke enquêtes. D e opzet van deze studie is niet gericht op het testen van de waarde van het W IZ-model.

M et behulp van het W IZ-model is een gedetailleerde documentatie aangelegd van de casus $\mathrm{H}$ artslag Limburg over een periode van drie jaar: van oktober 2002 
tot oktober 2005. H et object van studie betreft de samenwerking van $\mathrm{H}$ artslagpartners die op bestuurlijk niveau betrokken waren bij de uitvoering van de interventies van $\mathrm{H}$ artslag Limburg. D e actoren in dit onderzoek zijn: de portefeuillehouders van de gemeenten $M$ aastricht, $M$ eerssen, $M$ argraten, Valkenburg a/d Geul en Eijsden, Ieden van gemeentelijk raadscommissies, ambtenaren volksgezondheid, directie, staf, middelmanagement en de projectleider $\mathrm{H}$ artslag Limburg van de GGD, directie en middelmanagement van het regionale welzijnswerk, participerende huisartsen in de regio, directie azM , management van de afdeling $\mathrm{C}$ ardiologie en latere $\mathrm{H}$ art-Vaatcentrum i.o. van het azM en de contactpersoon van de betrokken zorgverzekeraar.

Verandermanagement is ged efinieerd als de activiteiten die vanuit de GGD door directie, staf, middelmanagement en de projectleider $\mathrm{H}$ artslag Limburg worden ondernomen om verankering van de samenwerking rond de preventie van harten vaatziekten te bevorderen.

$\mathrm{N}$ iet opgenomen in dit onderzoek is de samenwerking tussen $\mathrm{H}$ artslagpartners rondom de verschillende evaluatieve studies, c.q de samenwerking tussen GGD, $U$ M en RIVM . De reden hiervoor is dat de samenwerking op onderzoeksgebied geen consistent onderdeel is geweest van de continueringsdoelstelling van $\mathrm{H}$ artslag Limburg. Immers, het onderzoek binnen $\mathrm{H}$ artslag was opgesteld om eenmalig resultaten zichtbaar te maken, niet vanuit een visie op een blijvende samenwerking tussen 'onderzoek' en 'praktijk' als voorwaarde voor een effectieve 'new public health'. O mdat die visie gaandeweg wel gemeen goed is geworden, zie 0.a. de opkomst van academische werkplaatsen publieke gezondheidszorg, is deze relatie op een enkele plek in de casus beschrijving zichtbaar gemaakt (paragraaf 8.3.5).

\subsubsection{Dataverzameling}

D ataverzameling heeft plaatsgevonden door documentstudie van notulen, rapporten, (nieuws) brieven, samenwerkingscontracten, werkdocumenten, emails, nota's, conceptnota's en dergelijke (1994-2005), het bijhouden van een managementdagboek (2002-2005), en door twee dataverzamelingsrondes met schriftelijke enquêtes en individuele interviews met actoren. D eze rondes vonden plaats medio 2003 en medio 2004. In bijlage 4 is een voorbeeld van de vragenlijst voor enquête en interviews opgenomen. Een aantal vragen zijn, ter wille van de begrijpelijkheid en relevantie, per doelgroep op aangepaste wijze verwoord. Voor de interviews is gebruik gemaakt van een getrainde research-assistent. Alle interviews zijn op band opgenomen en van alle interviews zijn letterlijke transcripten gemaakt.

D e dataverzameling is als volgt gekoppeld aan de deelvragen: 
- Voor de beantwoording van de eerste en tweede deelvraag, - 'W elke elementen van verandermanagement worden toegepast?' en 'In hoeverre vindt er in de loop van de tijd daadwerkelijk bestuurlijke verankering plaats?' - is een eerste feitenbeschrijving gemaakt op basis van data uit bovengenoemde documentstudie, aangevuld met data uit dagboek en summier uit interviews. Vanwege de leesbaarheid en beoordeelbaarheid voor externe experts lag in deze eerste feitenbeschrijving het accent op data betreffende de dimensies verandermanagement en verankering. $D$ ata betreffende de overige dimensies werd in mindere mate opgenomen. D eze beschrijving is separaat gevalideerd (zie onder).

- Voor beantwoording van de derde en daaropvolgende deelvragen is gebruik gemaakt van een documentstudie en het dagboek. M et dit materiaal is de eerste feitenbeschrijving gecomplementeerd tot een volledige feitenbeschrijving (zie 3.4.3 en bijlage 2). V ia triangulatie van feitenbeschrijving met data uit de interviews en enquêtes is een tijdreeksanalyse geconstrueerd welke geordend is conform het W IZ-model. $0 \mathrm{p}$ geleide van de overige deelvragen is het materiaal van de tijdreeksanalyse stapsgewijs geanalyseerd (zie 3.4.3).

\section{Respons}

Voor de interviewronde van 2003 werden 47 actoren gesel ecteerd. Van deze 47 personen gingen uiteindelijk 37 personen akkoord met een interview (non-respons van $21 \%$ ). Redenen voor de non-respons waren 'te druk' (3 personen), 'niet genoeg kennis van deze materie' (2 personen), 'overige redenen', waaronder het al ingevuld hebben van de schriftelijke enquête ( 5 personen). Voor de interviewronde van 2004 werden 40 personen benaderd. U iteindelijk kon met 22 van hen een interview gehouden worden (non-respons van 45\%). Belangrijkste redenen voor de hogere non-respons waren het verloop van actoren (twee portefeuillehouders, directie GGD, enkele raadsleden) of de inschatting dat men ten opzichte van het vorige interview weinig had toe te voegen (7 personen). $\mathrm{H}$ et ontbreken van interviews met de twee opeenvolgende GGD directeuren geldt als een tegenvaller voor dit onderzoek. Dit is niettemin redelijk gecompenseerd door gebruikmaking van notulen en dagboekaantekeningen van informele overleggen.

Voor de enquêteronde van 2003 zijn 139 personen benaderd: alle leden van D B en $A B$ van de $G G D$, alle leden van de vijf gemeentelijke raadscommissies Welzijn en gezondheid, alle ambtenaren volksgezondheid en hun afdelingshoofden, 7 actoren van het welzijnswerk, 32 van de 35 huisartsen die al eerder in $\mathrm{H}$ artslag Limburg participeerden, en 19 actoren in het azM (zie tabel 3.1). De respons betrof 78 personen (56\%). $0 \mathrm{~m}$ de redenen van non-respons te achterhalen is in 2003 een telefonisch non-respons onderzoek uitgevoerd. In dit 


\begin{tabular}{|c|c|c|c|c|c|c|}
\hline \multirow[b]{2}{*}{ sector } & \multicolumn{3}{|l|}{2003} & \multicolumn{3}{|l|}{2004} \\
\hline & $\begin{array}{l}\text { totaal } \\
\text { aantal }\end{array}$ & $\begin{array}{l}\text { respons } \\
\mathrm{n}(\%)\end{array}$ & $\begin{array}{l}\text { non- } \\
\text { respons } \\
\text { n (\%) }\end{array}$ & $\begin{array}{l}\text { totaal } \\
\text { aantal }\end{array}$ & $\begin{array}{l}\text { respons } \\
\mathrm{n}(\%)\end{array}$ & $\begin{array}{l}\text { non- } \\
\text { respons } \\
\text { n }(\%)\end{array}$ \\
\hline Gemeenten & 81 & $39(48 \%)$ & 42 (52\%) & 76 & $26 \quad(34 \%)$ & $50 \quad(66 \%)$ \\
\hline Welzijnswerk & 7 & $5 \quad(71 \%)$ & $2 \quad(29 \%)$ & 6 & $3 \quad(50 \%)$ & $3 \quad(50 \%)$ \\
\hline Huisartsen & 32 & $22(69 \%)$ & $10 \quad(31 \%)$ & 32 & $16(50 \%)$ & $16(50 \%)$ \\
\hline $\mathrm{AzM}$ & 19 & $12(63 \%)$ & $7 \quad(37 \%)$ & 17 & $7 \quad(41 \%)$ & $10(59 \%)$ \\
\hline Totaal respons & 139 & $78(56 \%)$ & 61 (44\%) & 131 & $52(40 \%)$ & 79 (60\%) \\
\hline
\end{tabular}

Tabel 3.1 Respons schriftelijke enquêtes in 2003 en 2004

onderzoek bleken 7 personen telefonisch niet bereikbaar. Van de 52 wel bereikte personen gaven 7 personen aan de vragenlijst niet ingevuld te hebben maar wel een interview te willen geven. $D$ it is vervolgens gerealiseerd. $D$ aarnaast bleken 12 personen de vragenlijst alsnog in te willen vullen, maar slechts een beperkt aantal hebben dit ook daadwerkelijk gedaan. Zes personen, allen raadsleden, waren bereid telefonisch een verkorte versie van de vragenlijst te beantwoorden; zes personen wilden geen medewerking verlenen, waarvan de helft om reden dat zij niet langer lid van de raadscommissie waren. Verder gaven nog eens 5 personen aan zich zelf onvoldoende geïnformeerd te vinden om de vragenlijst in te kunnen vullen en waren er 13 personen die het 'te druk' hadden om de vragenlijst in te vullen. D e totale non-repons in 2003 betrof uiteindelijk voor het overgrote deel raadsleden die zich zelf om verschillende redenen niet in staat achten om de vragenlijst in te vullen.

0 ok in 2004 is een (beperkt) non-respons onderzoek uitgevoerd. Van de 32 personen die bereikt werden wilden 8 alsnog de vragenlijst insturen, 16 gaven aan onvoldoende geïnformeerd te zijn, en 8 hadden geen tijd of wilden niet. De toename van de non-respons in $2004(60 \%)$ ten opzichte van $2003(44 \%)$, blijkt bij alle sectoren plaats te vinden, zij het bij de gemeenten iets sterker dan bij de andere sectoren. D e consequentie van deze tamelijk hoge non-respons is dat de resultaten met name kwal itatief geïnterpreteerd moeten worden. D it laatste past overigens bij de opzet van deze studie.

Tot slot bleek bij de respons van beide enquêterondes sprake van een wisselende partiële non-respons. Vooral bij meer technische vragen, bijvoorbeeld over de invloed van landelijke rapporten en wetgeving, vulden respondenten "bij gebrek aan inzicht" geregeld geen antwoord in. Dit is in de tabellen in de hiernavolgende hoofdstukken zichtbaar gemaakt door per item van de vragenlijst het aantal respondenten te vermelden. 


\subsubsection{Analyse en validering}

D e belangrijkste analyse betrof de chronologische weergave van relevante ge beurtenissen, door middel van het verzamelen van documenten, verslagen, powerpoint-presentaties, emails en dagboekaantekeningen. Zoals in de vorige paragraaf al toegelicht is een eerste feitenbeschrijving later aangevuld met alle details betreffende lokale context en externe factoren tot een volledige chronologische feitenbeschrijving. Vervolgens zijn alle gegevens ('gebeurtenissen') omgezet in een data-matrix, het eerste deel van de tijdreeksanalyse. Voor deze datamatrix is gebruik gemaakt van de modellen van M iles \& H uberman (1994). D e matrix bestaat uit kolommen die gerangschikt zijn volgens de dimensies van het W IZ-model. D e rijen bevatten de chronologisch geordende data. D e cellen zijn gevuld door elke gebeurtenis te beoordelen op basis van de definities uit tabel 'Factoren en veronderstellingen behorend bij het W IZ-model' (bijlage 1) en vervolgens toe te kennen aan een dimensie en daarbinnen aan een factor (bijlage 2). Beoordeling van elke gebeurtenis hield tevens in dat een oordeel gegeven werd of de gebeurtenis een positieve (bevorderende) dan wel een negatieve (belemmerende) invloed had op de beoogde bestuurlijke verankering van de samenwerking. D e beoordeling van de gebeurtenissen naar factor en uitwerkingsrichting is gebaseerd op de 'veronderstellingen' en 'indicatoren' van het WIZmodel zoals beschreven in paragraaf 3.2 en 3.5 (herziene versie na advisering van het expertpanel). $\mathrm{H}$ et totaal aan positieve en negatieve gebeurtenissen is vervolgens zichtbaar gemaakt in staafdiagrammen waarin de aantallen gebeurtenissen gerangschikt zijn naar dimensie, factor en jaartal (figuren 5.1 t.m 5.3, 6.1

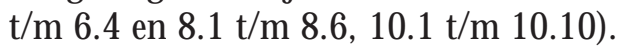

Alle interviews zijn op een analoge manier geanalyseerd: uitspraken zijn per respondent gerangschikt naar factor van het W IZ-model en gelabeld als hebbende een positieve of negatieve invloed. D e daaruit voortvloeiende matrixtabellen vormen het tweede deel van de tijdsreeksanalyse. D e scores van deze tabellen zijn echter niet in frequenties weergegeven omdat de kwalitatieve nuances van de uitspraken daarmee onrecht gedaan zou worden. D it materiaal is per thema inhoudelijk, en dus niet kwantitatief, vergeleken met de thema's die uit de feitenbeschrijving voortkomen.

D e resultaten uit de enquêtes zijn eveneens gerangschikt conform het WIZmodel: het derde deel van de tijdreeksanalyse. 0 ok deze data zijn vooral in kwalitatieve zin geanalyseerd.

U it de chronologische beschrijving van de casus blijkt dat het verankeringsproces min of meer gescheiden verlopen per echelon. Bovendien betrof het overgrote deel van de gebeurtenissen het gemeentelijke deel van $\mathrm{H}$ artslag Limburg. In de analyse is daarom voornamelijk gefocust op dit gemeentelijke deel. H et hoogrisico-deel, specifiek de samenwerking tussen GGD en academisch zieken- 
huis komt summier aan bod. Als bestuurders betrokken bij de verankering van het gementelijke deel zijn gedefinieerd: de portefeuillehouders volksgezondheid van de vijf gemeenten, allen tevens lid van Dagelijks en Algemeen Bestuur van de GGD , de directie van de GGD en de directie van het regionale welzijnswerk. In het hoogrisico-deel is geen onderscheid gemaakt tussen bestuurders (directie azM ) en andere actoren (hoogleraar, cardiologen en huisartsen).

$D$ e resultaten uit eerste, tweede en derde deel van de tijdreeksanalyse zijn daarna per dimensie en factor van het WIZ-model op een systematische manier onderling vergeleken (triangulatie). H et zwaartepunt van de analyse is daarbij gelegd op het eerste deel van de tijdreeksanalyse (de volledige feitenbeschrijving), omdat in de detaillering van de loop der feitelijke gebeurtenissen al tamelijk scherp naar voren komt welke factoren en thema's op welke momenten gespeeld hebben. Per dimensie, per factor en per jaar is gekeken welke gebeurtenissen speel den en welke thema's daarin te herkennen waren. $D$ it levert een groot aantal (voorlopige) conclusies op. Vervolgens is in interviews en enquêtes gezocht naar de meningen van actoren over deze gebeurtenissen c.q. thema's. Uitspraken van de bestuurders kregen daarbij het meeste gewicht. In het contrast tussen feitelijke gebeurtenissen en diversiteit van meningen wordt onder andere helder dat mensen niet altijd zeggen wat ze doen, en niet altijd doen wat ze zeggen. Eerdere conclusies worden daardoor genuanceerd, verworpen of juist onderstreept. D it zelfde proces wordt nog eens herhaald door de conclusies op niveau van thema's, factoren en dimensies onderling te vergelijken. D e resultaten van deze triangulatie worden gepresenteerd in de hoofdstukken $5 \mathrm{t} / \mathrm{m} \mathrm{10}$. Voor de opbouw van deze hoofdstukken is in principe gekozen voor handhaving van de stapsgewijze analyse per bron: per factor worden eerst de resultaten uit de feitenbeschrijving gepresenteerd, en daarna de confrontatie met data uit interviews en enquêtes. H oewel deze aanpak helder is qua logische opbouw leidt dit bij factoren die veel thema's bevatten tot een herhaling van onderwerpen. $D$ aarom is voor de leesbaarheid op sommige plekken gekozen om de resultaten uit de drie bronnen direct per thema gëntegreerd te presenteren, in plaats van per successievelijke bron.

D ata uit beide enquêterondes zijn ingevoerd in SPSS en geanalyseerd op basis van frequentietabellen. De kwalitatieve opzet van dit onderzoek heeft geleid tot de keuze om zo veel respondenten als maar mogelijk uit de verschillende groepen actoren te werven, in plaats van te proberen om een aselecte representatieve steekproef uit de populatie te trekken. D e consequentie hiervan is dat significantie in dit onderzoek niet relevant is.

\section{Validering}

Voor de uitvoering van dit onderzoek is gekozen voor een aanpak die zo dicht mogelijk staat bij de dagelijkse praktijk. De centrale onderzoeker was tot mei 
2004 tevens projectleider van $\mathrm{H}$ artslag Limburg. Voordeel hiervan is dat veel ontwikkelingen, en met name de verandermanagementactiviteiten, op de voet gevolgd konden worden, en dat informele signalen werden opgepikt. Belangrijk nadeel hiervan is echter het risico van verminderde objectiviteit en dus validiteit van het onderzoek. H et kan zijn dat gegevens gemist zijn juist omdat het onderzoek uitgevoerd is vanuit de GGD , en het kan zijn dat respondenten in hun antwoorden beïnvloed werden doordat zij het belang van de GGD mee lieten tellen.

O $\mathrm{m}$ deze vormen van bias zo goed als mogelijk op te vangen zijn de volgende stappen ondernomen:

- Voor correspondentie van het onderzoek (vragenlijsten, begeleidende brieven) is steeds gebruik gemaakt van briefpapier van de U M .

- Voor de persoonlijke interviews is gebruik gemaakt van een apart aangestelde en getrainde research-assistent.

- Voor de beantwoording van de eerste en tweede deelvraag, - 'W elke el ementen van verandermanagement worden toegepast?' en 'In hoeverre vindt er in de loop van de tijd daadwerkelijk bestuurlijke verankering plaats?' - is een eerste fei ten beschrijving gemaakt (zie 3.4.2). D eze feitenbeschrijving is ter validering voorgelegd aan zowel een drietal direct betrokkenen binnen de GGD (staflid, manager, projectcoördinator) als voor wat betreft de rubricering en codering aan twee onafhankelijke assessors van de U M . H et resultaat van deze eerste validering-stap, de bijgewerkt eerste feitenbeschrijving, is voorgelegd aan een extern expertpanel (zie 3.4.4).

- Een panel van drie onafhankelijke experts is ingezet om een oordeel te geven a) over de validiteit van het gebruikte WIZ-model, en b) over de validiteit van de operationalisering van het model (zie 3.4.5). Voor deze tweede valideringstap is gebruik gemaakt van bovengenoemde eerste feitenbeschrijving, aangevuld met belangrijke data uit de overige dimensies die nodig waren om de feitenbeschrijving juist te kunnen interpreteren. D e uitkomst van deze raadpleging is verwerkt in zowel het gebruikte model, als in de definities van factoren en de verdere analyses (zie 3.4.6).

- D e gevalideerde eerste feitenbeschrijving is gebruikt als basis voor de vol ledige feitenbeschrijving. $0 p$ basis van de verzamelde data uit volledige feitenbeschrijving zijn door drie assessors onafhankelijk van de onderzoeker parallelle matrices en staafdiagrammen gemaakt (derde validering-stap). D e verschillende analyses zijn vervolgens onderling vergeleken. $M$ et deze stap is de betrouwbaarheid getest: de mate waarin een herhaalde analyse van de database (de volledige feitenbeschrijving), met gebruikmaking van het onderzoeksprotocol (de definities van het W IZ-model), leidt tot dezelfde uitkomsten. Resultaat van deze exercitie was dat het hanteren van gelijke definities leidde tot vergelijkbare uitkomsten en omgekeerd. C onclusie was niet alleen dat de begrippen zo ver- 
fijnd mogelijk gedefinieerd moesten worden, maar ook dat sommige ge beurtenissen aan meer dan één factor toegewezen konden worden, en soms zowel positief als negatief beoordeeld konden worden. D e werkwijze bij de analyse is vervolgens hierop aangepast. $M$ et name bij dimensies lokale context en verandermanagement bleek het probleem van overlappende definities zich vaker voor te doen. Als oplossing is er voor gekozen om gebeurtenissen waar relevant te scoren op meerdere deelfactoren, en tevens het totaal aantal gebeurtenissen 'sec' te tellen; de som der scores op de deelfactoren valt daardoor dus hoger uit dan de score voor het totaal aantal gebeurtenissen binnen de dimensie. $D$ it is in de betreffende staafdiagrammen zichtbaar gemaakt (zie paragrafen 6.1 en 8.1). D e uiteindelijk definitieve feitenbeschrijving is opgenomen in bijlage 2 .

\subsubsection{Opzet Expertpanel}

D e onderzoeksdata zijn geanalyseerd aan de hand van het W IZ-model. 0 m die analyse te valideren, zowel t.a.v. de constructvaliditeit (in hoeverre weerspiegelen de gehanteerde begrippen en 'factoren' de werkelijkheid) als de interne validiteit (zijn de gehanteerde redeneringen logisch opgebouwd), is gebruik gemaakt van een expertpanel.

$D$ it panel bestaat uit een drietal externe deskundigen. D e competenties waar de leden van het expertpanel in gezamenlijkheid aan moesten voldoen zijn:

1. praktische ervaring met verandermanagement

2. ervaring als bestuurder binnen de overheid

3. kennis van de onderhavige public health sector: GGD, gemeente, huisartsen en ziekenhuis

4. kennis van de regio

5. onafhankelijkheid.

H et expertpanel bestond uit de volgende leden:

- Een voormalig ziekenhuismanager, deskundige verandermanagement en crisismanagement, tevens lid van de capaciteitsgroep BEO Z, U M

- Een hoogleraar sociale geneeskunde met tevens ervaring als bestuurder

- Directeur van een GGD, oud-huisarts, met tevens ervaring als bestuurder en lid van raad van toezicht van een landelijk instituut in de openbare gezondheidszorg.

M et deze keuze voldeed het panel aan de hierboven genoemde competenties. 
Taak expertpanel

D e volgende twee vragen zijn aan het expertpanel voorgelegd:

1. Zijn de factoren in het WIZ-model zoals beschreven in hoofdstuk 3.2 voldoende goed geoperationaliseerd en gedefinieerd? In andere woorden: is er een voldoende 'fit' tussen model en empirie?

2. Is in de bijgeleverde feitenbeschrijving de operationalisatie correct toegepast?

\section{Procedure}

Aan elk lid van het expertpanel zijn de vragen individueel voorgelegd. D e verkregen reacties zijn verwerkt en het resultaat daarvan is ter goedkeuring persoonlijk teruggekoppeld. Vervolgens zijn de individuele reacties gebundeld. Die synthese is besproken, gericht op het verkrijgen van maximale consensus, uiteraard met behoud van de kenmerkende verschillen tussen de beoordelaars onderling. D e interviews en de synthese zijn opgenomen in bijlage 3.

\subsubsection{Resultaten Expertpanel}

Validering van het WIZ-model

$U$ it de reacties van de experts op de eerste vraag komt scherp naar voren welke thema's en aspecten van samenwerking en verandermanagement zij relevant achten. D e experts blijken ieder een eigen benadering te hebben en verschillen daarin onderling. In elke benadering komen er zowel elementen naar voren die passen binnen het W IZ-model, als elementen van kritiek of aanvulling.

Expert 3 heeft de meeste kritiek op het WIZ-model als onderzoeksmodel omdat hij vindt dat het hele onderwerp beter vanuit een ander paradigma bekeken zou kunnen worden. $\mathrm{H}$ ij interpreteert de blokken en de pijlen in het model als een weergave van een rationeel proces, wat volgens hem conflicteert met de irrationaliteit die zo kenmerkend is voor het onderhavige sociaal-politieke proces. Expert 3 benadrukt dat modellen als het W IZ-model alleen met de nodige relativering gebruikt mogen worden. Vanuit die visie geeft hij aan dat hij vindt dat belangen centraal moeten staan, zij het inclusief de niet-geformaliseerde belangen. D e onderscheiden dimensies van het model worden door expert 3 onderschreven, maar verschillende elementen worden door hem additioneel genoemd: cultuur, stijl van leidinggeven, de invloed van persoonlijkheden en de informele organisatiestructuur (informeel leiderschap).

Expert 1 onthoudt zich van een uitspraak over het model als zodanig, maar somt de elementen op die hij van belang acht. G enoemd worden: 'sense of urgency' (urgentiebesef), draagvlak, doelstellingen en belangen, tussentijdse succesindica- 
toren, de korte spanningsboog voor verandering, risico van vertrek van oorspronkelijke pleitbezorgers, leiderschap en planmatig communiceren. In deze opsomming zijn verschillende factoren uit de dimensies van het WIZ-model herkenbaar.

Expert 2 onderschrijft de logische opbouw van het W IZ-model, als een acceptabele methode om relevante data uit de werkelijkheid van groepen actoren met hun kenmerken, relaties en allerlei gebeurtenissen en ontwikkelingen in de tijd te ordenen. "Wat ik in de beschrijving nu zie is een zorgvuldige beschrijving van het veel voorkomende proces, het politiek-bestuurlijke proces, dat ik vooral herken als een moeizame belangenstrijd, een gegeven realiteit in ons stelsel. D it is zoals de ontwikkelingen in deze sector meestal gaan." In zijn reactie legt hij nadruk op belangen en individuele chemie als centrale begrippen. In het WIZmodel staan belangen centraal binnen de dimensie determinanten van draagvlak; individuele chemie is een verfijning van de factor bestaande samenwerkingsrelaties binnen de dimensie lokale context. O nder verwijzing naar het nieuwe verzekeringsstelsel en de druk die dit gaf voor huisartsen, onderstreept expert 2 de relevantie van de dimensie externe factoren. Expert 2 legt nadruk op twee centrale elementen in het W IZ-model: op de dimensie draagvlak en verandermanagement. Verder merken expert 2 en 3 op dat de subverdeling binnen de dimensie verandermanagement onderling overlap vertoont.

U it de antwoorden van de experts valt allereerst te concluderen dat er bij de experts geen consensus maar een gevarieerde reactie bestaat over de 'fit' van het model. Enerzijds wordt het belang van de gekozen dimensies en factoren binnen het model merendeels onderschreven en worden deze dus gezien als passend bij de werkelijkheid. Anderzijds wordt door één expert (expert 3) aangegeven dat de in het model opgenomen samenhang (verbeeld via pijlen) niet past bij de werkelijkheid, een werkelijkheid die veelal juist niet logisch-rationeel verloopt. $\mathrm{N}$ aast deze principiële relativering van het model, is de tweede expert positief en de derde (expert 1) neutraal c.q. gaat helemaal niet in op modelvorming. Verder springen er drie zaken uit die als belangrijke aanvullingen op het model gekenmerkt moeten worden: de dynamiek tussen de actoren (tot uiting komend in divergerende belangenstrijd of convergerende persoonlijke chemie, hierna getypeerd als 'belangenstrijd'), het benodigde type leiderschap en 'sense of urgency'.

\section{Validering van de operationalisering}

D e conclusie uit vraagstelling 1 heeft uiteraard repercussies voor de beantwoording van vraagstelling 2 . H oewel de operationalisering vanuit het W IZ-model betreffende de dimensie verandermanagement op zichzelf weinig kritiek krijgt, ligt de essentie van de kritiek vooral bij datgene wat nog niet zichtbaar gemaakt is (materiaal over de andere dimensies) en bij hetgeen wellicht niet verzameld is 
als resultante van de aangegeven tekortkomingen van het model. Samenvattend gaat het om:

- het realiseren van de beoogde beschrijving van de andere dimensies (lokale context, externe factoren);

- een verantwoording geven ten aanzien van mogelijke selectiebias;

- laten zien dat het verzamelde materiaal voldoende rijk is om met name de belangenstrijd en de irrationele dynamiek daarvan overtuigend te beschrijven.

M ede op basis van de afgenomen interviews kan een deel van de gerezen vragen over selectiebias, belangenstrijd en irrationele dynamiek beantwoord worden. In de interviews met bijvoorbeeld de bestuurders worden verschillende pregnante uitspraken gedaan waarin GGD noch collega bestuurders gespaard worden. D it komt in de latere hoofdstukken aan bod. N iettemin moet worden erkend dat uitvoering van dit onderzoek vanuit de GGD en U M selectiebias in de hand kan hebben gewerkt. $\mathrm{H}$ et is mogelijk dat er in de casus relevante zaken gespeeld hebben, bijvoorbeeld bij gemeenten, die buiten het gezichtsveld van de onderzoeker zijn gebleven, juist vanwege de verwevenheid van belangen. $D$ it, ondanks de in 3.4 .3 beschreven maatregelen. Anderzijds, zoals bekend valt selectiebias nooit geheel uit te sluiten bij studies naar dit soort processen. Dit omdat het nu eenmaal onmogelijk is om alle denkbare gegevens te verzamelen, zelfs niet als een uitgewerkt model zo zorgvuldig mogelijk wordt geoperationaliseerd en volgens de gel dende methodologische regels dataverzameling wordt toegepast.

H etgeen aansluit bij het paradigma van expert 3: wij kunnen een groot deel van de werkelijkheid beschrijven, maar nooit de hele. $\mathrm{H}$ et is aan de lezer om te beoordelen in hoeverre dit onderzoek daarin is geslaagd.

Samenvattend: de operationalisering kan voldoen wanneer deze aangepast wordt op de genoemde punten.

\subsection{Conclusie voor het WIZ-model en de onderzoeksmethode}

Welke betekenis wordt hier gegeven aan de reacties van de experts? G ebaseerd op het gegeven dat veel elementen van het W IZ-model worden genoemd, wordt hier geconcludeerd dat dit model in de basis een bruikbaar model is voor dit onderzoek. De principiële relativering van expert 3 wordt herkend: inderdaad gaan dit soort processen in belangrijke mate langs niet-rationele weg. H et WIZ-model is geënt op de open systeem theorie, hetgeen inhoudt dat het gaat om een ordeningsmodel waarin de pijlen inderdaad wederzijds gaan. In dit onderzoek echter wordt gezocht naar een patroon met een bepaalde richting als hypothese (in hoeverre kan het GGD management verankering 
bevorderen), hetgeen de reden is om de pijlen toch een richting te geven. D e onderzoeker verwelkomt de drie aanvullingen. D eze zijn verwerkt in een nieuwe versie van het WIZ-model (figuur 3.3).

$M$ et deze aanpassingen is tevens de basis gelegd voor de conclusie die voortkomt uit de vraag omtrent de validiteit van de operationalisering. H et nieuwe model is het ordeningskader geworden waarmee het onderzoeksmateriaal opnieuw is geordend en vervolgens geanalyseerd. $0 p$ deze wijze is invulling gegeven aan het zo goed mogelijk afdekken van het risico op selectiebias en het zo rijk mogelijk beschrijven van de toegevoegde factoren. $\mathrm{H}$ et resultaat van dit alles wordt beschreven in de volgende hoofdstukken.

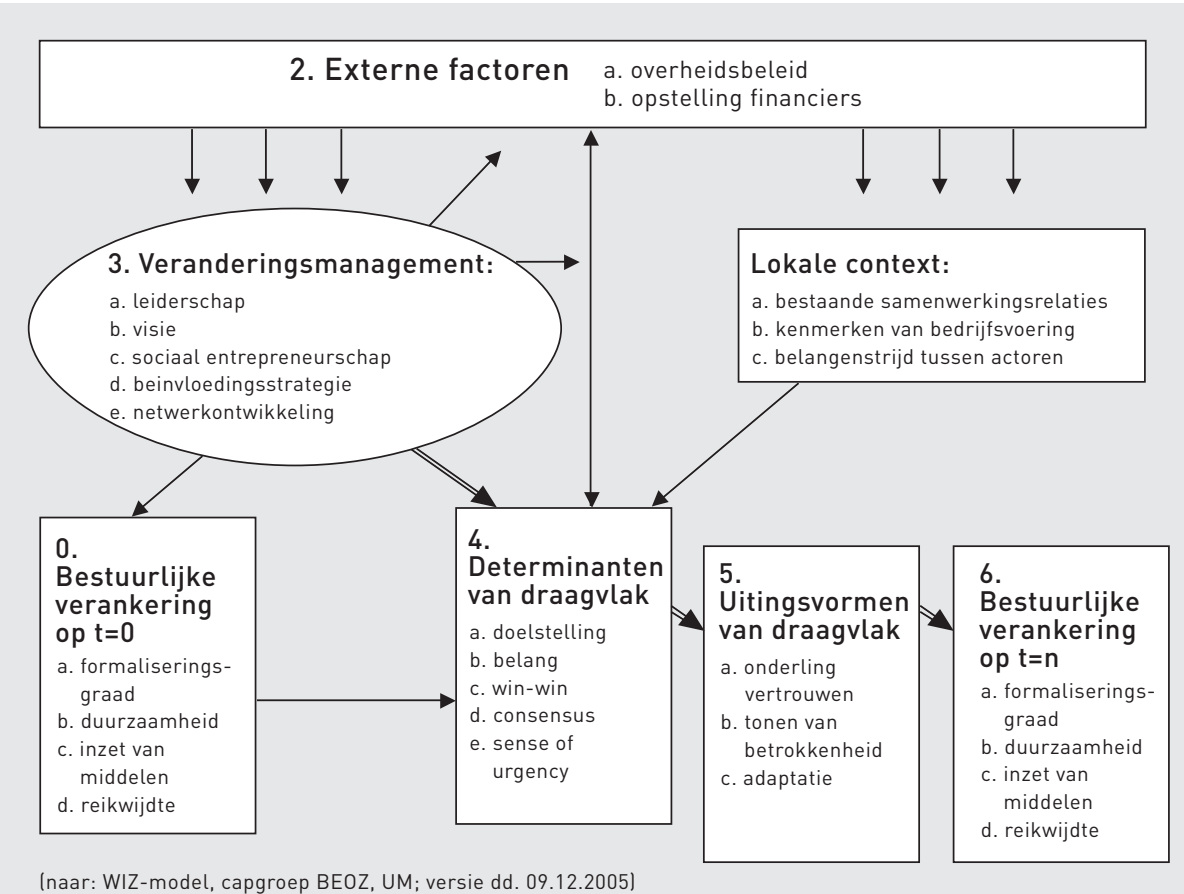

Figuur 3.3 WIZ-model voor bestuurlijke verankering van samenwerking tussen de GGD en haar omgeving, versie na validering met expertpanel ldecember 2005); toegevoegd zijn de factoren: 'leiderschap', 'belangenstrijd tussen actoren' en 'sense of urgency'. 


\section{Hoofdstuk 4 De casus: de bestuurlijke verankering van Hartslag Limburg}

\subsection{Inleiding}

In dit hoofdstuk worden de belangrijkste resultaten uit de documentstudie gepresenteerd: de mate van bestuurlijke verankering ten tijde van begin- en eindmeting (paragraaf 4.2), en een chronologische beschrijving van de gebeurtenissen die zich daartussen afspeelden (paragraaf 4.3).

Bepaling van het niveau van bestuurlijke verankering heeft plaatsgevonden door middel van documentstudie van relevante beleidsnota's, contracten en werkdocumenten. D e concepten van de begin- en eindmeting zijn ter verificatie voorgelegd aan betrokken managers en stafleden.

De chronologische beschrijving biedt en zo feitelijk mogelijk overzicht op hoofdlijnen en wordt afgesloten met een eerste opsomming van de factoren die invloed gehad hebben op het eindresultaat qua bestuurlijke verankering. D e chronologische beschrijving is gemaakt op basis van de feiten beschrijving (zie bijlage 2), zoals beschreven in hoofdstuk 3.

In de latere hoofdstukken volgt een nadere analyse op geleide van de verschillende dimensies die het W IZ-model onderscheidt. In deze hoofdstukken worden ook beide andere databronnen, de interviews en enquêtes, betrokken in de analyses (triangulatie).

\subsection{De bestuurlijke verankering: begin-en eindmeting}

Centraal in de opbouw van $\mathrm{H}$ artslag Limburg was de doelstelling om te komen tot "de realisering van een blijvende samenwerking tussen de drie echel ons (publieke gezondheidszorg, huisartsen en specialisten)". D eze in 1995 al geformuleerde doelstelling was bewust gekozen omdat inmiddels uit de literatuur bekend was hoe innovaties verloren kunnen gaan wanneer de onderzoeksfase wordt beëindigd en een deel van de partners zich terugtrekt. M ede vanuit deze kennis werd ingezet op een grondige wetenschappelijke evaluatie, want cijfers en 'evidence' over gezondheidswinst moesten wel de onderbouwing leveren voor het nut van de samenwerking.

Samenwerking tussen de partners, te weten gemeenten, welzijnswerk, GGD , huisartsen, het azM en de U M was op bestuurlijk niveau vormgegeven door 
middel van een Stuurgroep, onder voorzitterschap van de directie van de GGD . $D$ e dagelijks leiding was gedelegeerd aan de projectleider die sturing gaf aan de voortgang via werkoverleggen met de verschillende uitvoerende teams.

D e samenwerkingsafspraken bestonden bij de start in 1998 uit meerjarige contracten en subsidietoekenningen van de gemeenten. Een belangrijke overgang vond plaats in 2001. Vanaf dat jaar stopte conform de planning de bijdrage van de N H S aan de uitvoering van de interventies in zowel het community- als het hoogrisicodeel van $\mathrm{H}$ artslag Limburg. D e financiering van de onderzoeksprojecten liep gewoon door. H et financiële gat in de uitvoeringskosten werd voor een periode van drie jaar gevuld door bijdragen van zorgverzekeraar VGZ (hoogrisicodeel), en een uitbreiding van de bijdragen van de gemeenten. $M$ et name deze bijdrage van de gemeenten kwam heel moeizaam tot stand (zie hoofdstuk 2.5.4).

Niveau van verankering in 2002

D e situatie ten aanzien van het niveau van bestuurlijke verankering van de samenwerking in oktober 2002, dus bij aanvang van deze studie op $t=0$, is weergegeven in tabel 4.1. Te zien is dat de formalisatiegraad vooral een contractueel karakter had, waarbij alleen binnen de gemeente $M$ aastricht sprake was van inbedding in door de gemeenteraad formeel nagestreefd beleid, namelijk het $G$ rote Stedenbeleid. Alle afspraken hadden verder een tijdelijk, driejarig karakter (aspect duurzaamheid). Inzet van middelen voor de uitvoering betrof in totaal ruim vijf ton. Door middel van de inzet van ongeveer 7,5 fte werden in vijf gemeenten acht werkgroepen, en acht huisartspraktijken, plus de afdeling Cardiologie van het azM ondersteund (reikwijdte).

Niveau van verankering in 2005

M eting op dezelfde punten drie jaar later geeft een heel ander beeld (tabel 4.1). $\mathrm{H}$ artslag Limburg is omgevormd van een samenwerkingsproject naar een twee tal producten van de GGD. Beide producten, voortkomend uit het communitydeel van $\mathrm{H}$ artslag Limburg, zijn opgenomen in het basispakket van de GGD , hetgeen inhoudt dat alle gemeenten dit standaard afnemen. D e producten zijn de uitvoering van het door de gemeenten in hun nota's vastgel egde lokale gezondheidsbeleid. H et lijkt op dit punt dat de formalisatiegraad en de duurzaamheid zijn toegenomen. Echter, dit geldt alleen voor de samenwerking gemeenten - GGD. H et welzijnswerk vormt geen geformal iseerd onderdeel van deze samenwerking: deze samenwerking wordt voortgezet op basis van inkoop van diensten. $\mathrm{D}$ aarnaast is de samenwerking met de huisartsen beëndigd, terwijl de samenwerking met het azM op contractuele basis voor tweeënhalf jaar is gecontinueerd en qua inzet van middelen en reikwijdte zelfs is uitgebreid. Q ua inzet van middelen zijn het netwerkmanagement en het community-deel er flink op 


\begin{tabular}{|c|c|c|}
\hline & Bestuurlijke verankering op $t=0$ (oktober 2002) & Bestuurlijke verankering op $t=1$ (oktober 2005) \\
\hline $\begin{array}{l}\text { a) } \\
\text { Formalisa- } \\
\text { tiegraad }\end{array}$ & $\begin{array}{l}\text { De samenwerkingsafspraken bestaan uit: } \\
\text { 1. een uit 1998/1999 daterende basissamenwerkingsovereenkomst } \\
\text { tussen Nederlandse Hartstichting, GGD en Universiteit Maastricht } \\
\text { met bilaterale subcontracten tussen GGD en uitvoerende partners } \\
\text { (UM capgroep HAG, afdeling Cardiologie van het azM, } \\
\text { welzijnswerkorganisaties Trajekt en SWEH) } \\
\text { 2. bijbehorende subsidietoekenningen van gemeenten aan GGD en } \\
\text { welzijnswerk, deels o.b.v. instellingssubsidie, deels projectsub- } \\
\text { sidie (waaronder in Maastricht als formeel onderdeel van het } \\
\text { GSB-beleid) } \\
\text { 3. subsidietoekenning van VGZ voor de implementatie van gezond- } \\
\text { heidsadviseurs in het ziekenhuis en een aantal huisartspraktijken. }\end{array}$ & $\begin{array}{l}\text { De samenwerkingsafspraken bestaan uit: } \\
\text { 1. een product Lokale Gezondheidsbevordering is opgenomen in } \\
\text { vigerende nota Lokaal Gezondheidsbeleid van alle gemeenten. } \\
\text { 2. de producten 'Programma ontwikkeling lokaal gezondheidsbeleid' } \\
\text { en 'Lokale gezondheidsbevordering' zijn als basisproduct (binnen } \\
\text { het wettelijke standaardpakket) opgenomen in de door de vijf } \\
\text { gemeenten goedgekeurde Productbegroting } 2005 \text { van de GGD. } \\
\text { 3. de samenwerking met het welzijnswerk vindt plaats op basis } \\
\text { van inkoop van diensten. } \\
\text { 4. geen actuele samenwerking met huisartsenpraktijken. } \\
\text { 5. de samenwerking tussen GGD en azM verloopt op basis van een } \\
\text { projectmatig contract. }\end{array}$ \\
\hline $\begin{array}{l}\text { b) } \\
\text { Duurzaam- } \\
\text { heid }\end{array}$ & $\begin{array}{l}\text { Ad 1: tijdelijk voor de projectduur, gepland tot eind } 2003 \\
\text { Ad 2: tijdelijk, op jaarbasis voor de periode } 2001 \text { t/m } 2003 \\
\text { Ad 3: tijdelijk, voor de periode april } 2001 \text { t/m maart } 2004\end{array}$ & $\begin{array}{l}\text { Ad 1: structureel, binnen de tijdsduur van de gemeentelijke nota's } \\
\text { Ad 2: structureel } \\
\text { Ad 3: ad hoc } \\
\text { Ad 5: tijdelijk voor de periode december } 2003 \mathrm{t} / \mathrm{m} \text { juni } 2006\end{array}$ \\
\hline $\begin{array}{l}\text { c) } \\
\text { Inzet van } \\
\text { middelen }\end{array}$ & $\begin{array}{ll}\text { 1. Netwerkmanagement: } & € 98.000 \text { (PM: excl. relatie UM-RIVM) } \\
\text { 2. Community-project: } & € 319.000 \\
\text { 3. Hoogrisico-project: } & € 104.000 \\
\text { totaal: } & € 521.000\end{array}$ & $\begin{array}{ll}\text { 1. Netwerkmanagement: } & € 62.000 \\
\text { 2. Community-project: } & € 190.000 \\
\text { 3. Hoogrisico-project: } & € 124.000 \\
\text { totaal: } & € 376.000\end{array}$ \\
\hline
\end{tabular}




\begin{tabular}{|c|c|c|c|}
\hline \multirow[t]{3}{*}{$\begin{array}{l}\text { d) } \\
\text { Reikwijdte }\end{array}$} & $\begin{array}{l}\text { 1. Netwerk- } \\
\text { management } \\
\text { GGD }\end{array}$ & $\begin{array}{l}\text { - Projectleider (0,6 fte) (=excl. relatie UM en RIVM) } \\
\text { - Coördinator Community-project (0,2 fte) } \\
\text { - PR-functionaris }(0,4 \mathrm{fte}) \\
\text { - Ontwikkel- en pr-budget }\end{array}$ & $\begin{array}{l}\text { - Coördinator Gezondheidsbevordering }(0,5 \mathrm{fte}) \text { en staflid innovatie } \\
(0,1 \mathrm{fte}) \\
\text { - PR-functionaris: niet begroot } \\
\text { - Ontwikkel-en pr-budget }\end{array}$ \\
\hline & $\begin{array}{l}\text { 2. Community- } \\
\text { project }\end{array}$ & $\begin{array}{l}\text { Voor } 8 \text { werkgroepen in } 5 \text { gemeenten in totaal: } \\
\text { - GVO-functionaris (1,8 fte) } \\
\text { - Welzijnswerker (2,0 fte) } \\
\text { - Ambtenaar ( } \pm 0,5 \mathrm{fte}) \text { (bijdrage per gemeente } \\
\text { sterk wisselend) } \\
\text { - Werkgroepbudgetten }\end{array}$ & $\begin{array}{l}\text { Voor activiteiten in } 5 \text { gemeenten en } 4 \text { buurten: } \\
\text { - GVO-functionaris (1,0 fte) } \\
\text { - Welzijnswerker }(0,3 \mathrm{fte}) \\
\text { - - } \\
\text { - Activiteitenbudget } \\
\text { - PM: verbreding van het aantal gezondheidsthema's }\end{array}$ \\
\hline & $\begin{array}{l}\text { 3.Hoogrisico- } \\
\text { project }\end{array}$ & $\begin{array}{l}\text { - Gezondheidsadviseurs (1,0 fte) t.b.v. } 8 \\
\text { huisartspraktijken } \\
\text { - Gezondheidsadviseurs (1,0 fte) t.b.v. afdeling } \\
\text { Cardiologie }\end{array}$ & - Gezondheidsadviseurs (1,7 fte) t.b.v. HartVaatCentrum azM \\
\hline
\end{tabular}

Tabel 4.1 Bestuurlijke verankering op t=0 en $t=1$; PM: niet opgenomen is de samenwerking ten behoeve van wetenschappelijk onderzoek. 
achteruit gegaan: het budget is met ongeveer eenderde gekrompen. Analoog hieraan is ook de reikwijdte sterk gekrompen: niet alleen is de formatie-omvang bij GGD en welzijnswerk gekrompen, ook de opgebouwde structuur met inzet van ambtenaren en lokale werkgroepen met vrijwilligers is afgebroken. Eigenlijk is de teruggang nog groter, want het aantal gezondheidsthema's dat met deze middelen geadresseerd moet worden is verbreed. Feitelijk een verkapte bezuiniging. $M$ et minder professionals, minder structuur en minder vrijwilligers moeten er meer taken tegelijk aangepakt worden.

D e conclusie is dat de bereikte bestuurlijke verankering in 2005 een grillig patroon vertoont. Van de vier aspecten van bestuurlijke verankering is er op twee aspecten, namelijk formalisati egraad en duurzaamheid, vooruitgang geboekt in de zin van sterkere verankering binnen de samenwerking tussen G GD en gemeenten. Binnen het community-deel van $\mathrm{H}$ artslag is er echter op de andere twee aspecten, inzet van middelen en reikwijdte, sprake van een duidelijke afname. $\mathrm{H}$ et niveau van de samenwerking is ongeveer gehalveerd.

O pmerkelijk is dus dat opname van het product Lokale Gezondheidsbevordering in de gemeentelijke nota's niet heeft geleid tot het beoogde niveau van bestuurlijke verankering. Per saldo is de lokale gezondheidsbevordering er flink op achteruit gegaan. Alleen de samenwerking met het ziekenhuis is op ongeveer gelijk niveau verankerd.

Wat heeft zich in de tussentijd afgespeeld? $\mathrm{H}$ eeft het verandermanagement gefaald, of waren andere factoren bepalend? G ebaseerd op de feitenbeschrijving (zie 3.4.3) worden als eerste aanzet in de volgende paragraaf de belangrijkste gebeurtenissen op een rij gezet. In de hoofdstukken daarna wordt het hele verankeringsproces vanuit de dimensies van het WIZ-model diepgaander geanalyseerd.

\subsection{Het bestuurlijk proces: een chronologisch overzicht}

\subsubsection{De openingszetten: gebeurtenissen in de periode oktober tot en met december 2002}

Begin oktober 2002 lijkt continuering van het community-deel van $\mathrm{H}$ artslag Limburg haalbaar omdat aan gemeenten geen extra investeringen gevraagd hoeven worden. Dit in tegenstelling tot de situatie in 2000 toen continuering voor de periode 2001-2003 betekende dat aan gemeenten gevraagd werd om hun bijdrage aanmerkelijk te verhogen (paragraaf 2.5.4). Verankering vanaf eind 2003 betreft enkel het handhaven van het al bestaande investeringsniveau. 
In juli 2002 is de nieuwe Wet Collectieve Preventie Volksgezondheid (W CPV) van kracht geworden die gemeenten verplicht om het eigen lokale gezondheidsbeleid uiterlijk per 1 juli 2003 vast te leggen in een nota. Argumentaties kunnen gemeenten halen uit het landelijke rapport Volksgezondheid Toekomst Verkenning 2002 (VTV) dat het RIV M op vijftien november van dat jaar presenteert (van $\mathrm{O}$ ers, 2002). In dit rapport wordt $\mathrm{H}$ artslag Limburg als 'best practice' naar voren gehaald en het rapport onderstreept in zijn conclusies het belang van continuïteit in preventie. Zowel de Volkskrant als D agblad D e Limburger schrijven over $\mathrm{H}$ artslag Limburg als een voorbeeld dat past in de conclusies van het RIV M -rapport (D 20, D 23). D e GGD benut het momentum door op 25 november een speciale introductieavond voor wethouders, ambtenaren en raadsleden te houden over de nieuwe WCPV, het rapport van het RIVM en de manier waarop de GGD hier al invulling aan geeft, o.a. via H artslag Limburg.

Een minder optimistisch geluid wordt echter al een paar dagen eerder in D en $\mathrm{H}$ aag geventileerd. M inister D e G eus (VW S) schrijft in zijn reactie op de VTV: "Investeren in preventie is absoluut noodzakelijk. (..) N aar mijn mening is de inzet van gemeenten, gemeentelijke gezondheids-diensten, thuiszorg en andere lokale organisaties hierbij uiterst noodzakelijk. Ik reken dan ook op ieders bijdrage. (..) Binnen de begroting 2003 van mijn departement is er thans geen ruimte om extra middelen hiervoor vrij te maken." (D 17). Of dit signaal doorgedrongen is tot de genodigden op de bijeenkomst op de GGD is onbekend. D e bijeenkomst is geëvalueerd met behulp van een korte vragenlijst die door 10 raadsleden is ingevuld (respons $31 \%$ ). $U$ it deze evaluatie komt naar voren dat de presentatie van de G GD gewaardeerd wordt met rapportcijfer 8 . D e bereidheid onder de respondenten om lokaal gezondheidsbeleid naar aanleiding van deze avond hoger te prioriteren op de gemeentelijke agenda lijkt aanwezig, maar het gewicht daarvan lijkt beperkt (zeven raadsleden antwoorden "eens", twee "oneens", maar bij een hoge non-respons van $69 \%$ blijft de impact twijfelachtig).

In de volgende maanden neemt de GGD het initiatief om via overleg met ambtenaren te bevorderen dat $\mathrm{H}$ artslag Limburg opgenomen gaat worden in de conceptnota's van de vijf gemeenten.

\subsubsection{Gebeurtenissen in de eerste helft van 2003: opbouw van de stellingen}

Begin 2003 kondigt het kabinet forse bezuinigingen aan op het gemeentefonds. $H$ ierdoor komt in menige gemeente in de regio ook de financiering van de GGD ter discussie. Eind januari laat de bij $\mathrm{H}$ artslag Limburg betrokken zorgverzekeraar in het overleg met de GGD en huisartsen weten dat voor continuering na 
2003 geen extra geld beschikbaar is; oplossingen moeten dus gezocht gaan worden binnen bestaande financieringstromen of via andere fondsen (D 33). Voor de GGD -staf is dit het signaal om de mogelijkheden te verkennen voor de integratie van $\mathrm{H}$ artslag Limburg in de eerste lijn met de ontwikkeling van praktijkondersteuners; voor de lijn in het ziekenhuis wordt gekeken naar inpassing van de gezondheidsadviseur in de zich ontwikkelende samenwerking van meerdere specialismen in een gezamenlijke hartvaat-poli.

O p 17 februari 2003 blijkt uit overleg met de ambtenaar volksgezondheid van $M$ aastricht dat, gezien het beperkte budget op gemeentelijk niveau, het onderbrengen van de $\mathrm{H}$ artslag activiteiten binnen de wettelijk verplichte taken de meeste kans biedt op continuering (D 39). D e eerste stap hiertoe is de nieuwe productbegroting 2004 van de GGD. D eze boodschap leidt binnen de GGD tot concrete actie. In overleg met het management beargumenteren de $\mathrm{H}$ artslagmedewerkers dat de nieuwe W CPV gemeenten verplicht om GVO vorm te geven, en $\mathrm{H}$ artslag Limburg is het product dat daar op wetenschappelijke verantwoorde wijze invulling aan geeft. D e H artslag-methode moet daarom gaan gelden als de nieuwe norm voor effectief G VO -beleid (D 43). Vanaf maart 2003 is $\mathrm{H}$ artslag Limburg opgenomen in het concept Productenboek 2004 van de GGD.

Begin maart is het voorpaginanieuws van de lokale kranten dat de gemeente $M$ aastricht 33 miljoen euro moet bezuinigen, en dit zal realiseren door alle afdelingen en diensten te korten met enkele procenten. D e gemeenten laten echter aan de GGD weten dat zij voor 2004 een uitzondering willen maken voor de GGD. Reden hiervoor is dat het bestuur (de gemeenten) en de directie al twee jaar worstelen over de bedrijfsvoering. D e GGD blijkt aan deze financiële tege moetkoming echter niet genoeg te hebben: in de loop van 2003 worden vele varianten van het productenboek op ambtelijk niveau getorpedeerd omdat de nieuwe tariefstructuur telkens te hoog uitkomt.

$0 \mathrm{~m}$ het draagvlak te vergroten stuurt de G GD eind maart een voortgangsrapportage over $\mathrm{H}$ artslag Limburg naar alle betrokkenen (D 54). H et rapport laat zien dat het project door de jaren volgens plan is verlopen, dat er samen met derden veel activiteiten zijn gerealiseerd met een goede waardering door de deelnemers, en dat er bij een tussenmeting in 2001 een klein effect op populatieniveau is gevonden. Echt relevante uitkomstcijfers worden pas over een jaar, medio 2004, verwacht. O p 10 april is er een miniconferentie in samenwerking met de eindredacteur van de VTV-2002 van het RIV M . Vanaf 16 april volgen presentaties voor de raadscommissies van alle gemeenten. $D$ e voortgang en resultaten van $\mathrm{H}$ artslag Limburg worden ook via een nieuwsbrief breed verspreid. Verder wordt $\mathrm{H}$ artslag Limburg opgenomen in een beleidsnotitie van de N H G en op 22 mei wordt het 'Beleidsplan functie Gezondheidsadviseur/zorgcoördi- 
nator' gepresenteerd aan het management van de betreffende BehandelZorgEenheid (BZE) van het azM (D 66). Dit beleidsplan is geschreven onder eindredactie van de projectleider van $\mathrm{H}$ artslag, op basis van cijfers en ideeën van azM en UM .

O p 20 maart 2003 presenteert de voorzitter van de raad van bestuur van het azM een toekomstvisie aan het dagelijks bestuur (DB) van de GGD waarin wordt beoogd om de bestaande samenwerking (waaronder $\mathrm{H}$ artslag Limburg) tussen GGD, azM en UM te institutionaliseren (D 49). Voorgesteld wordt om te komen tot de oprichting van een gezamenlijk 0 ntwikkelcentrum voor 0 penbare G ezondheidszorg, kortweg O OG, en te streven naar clustering van nieuwbouw op het terrein van het azM en de U M op een 'boulevard de la santé M aastricht'. D e gemeenten zijn intussen echter ook betrokken bij een groeiende consensus over een fusie tussen de drie Zuid-Limburgse GGD 'en (D 48). Bovendien melden alle gemeenten dat ze gemeenten moeite hebben met het financieel rond krijgen van hun begroting. In de loop van 2003 wordt snel duidelijk dat de fusie voorop komt te staan: als in mei de directeur van de GGD vertrekt wordt hij opgevolgd door een interim-directeur die als voornaamste opdracht van het bestuur meekrijgt het voorbereiden van de fusie. Voorjaar 2003 lukt het de GGD via frequente contacten met ambtenaren om $\mathrm{H}$ artslag Limburg opgenomen te krijgen in de conceptnota van de gemeente $M$ aastricht. D eze nota staat tevens model voor de nota's van de andere gemeenten. $0 \mathrm{p} 16$ juni wordt de nota in de raadscommissie van M aastricht besproken, waarbij de portefeuillehouder op vragen antwoordt dat het "nog te vroeg is om de financiële haal baarheid te bepalen" (D 69). D e raadscommissie accepteert dit en adviseert positief. 0 p 25 juni stelt de gemeenteraad de nota vast, waarin over $\mathrm{H}$ artslag Limburg vermeld wordt "de preventieactiviteiten los te koppelen van projectstructuren en onder te brengen in de reguliere taken van de GGD" (D 61). D ezelfde formulering wordt ook in de (concept)nota's van de andere gemeenten overgenomen. $0 \mathrm{p} 30$ juni spreekt in het azM het management van het BehandelZorgC entrum i.o. zich uit voor het opnemen van het concept van de gezondheidsadviseur binnen de plannen van het beoogde nieuwe $\mathrm{H}$ artVaatC entrum (D 81). Een week later wordt een projectgroep opgericht van GGD en azM die zal proberen om het initiatief in te passen in een subsidieverzoek aan het Fonds $0 \mathrm{GZ}$. H alverwege 2003 is dus een eerste niveau van verankering, de opname in regulier beleid, gerealiseerd voor zowel het communityproject in de gemeente $M$ aastricht als voor het hoogrisico-project in het azM . 


\subsubsection{De periode juli tot en met december 2003: het hoofdspel}

O p 4 juli volgt er een telefonisch bericht van de afdeling Welzijn van de gemeente $M$ aastricht aan de afdeling financiën van de GGD over de gemeentelijke bezuinigingsvoorstellen. D e afdeling financiën bericht per email aan het management van de GGD 0.a.: "H artslag moet ingebed worden in het reguliere beleid. $\mathrm{H}$ et budget dat het welzijnswerk van de gemeente krijgt voor $\mathrm{H}$ artslag zijnde $€ 91.000$ wordt naar de G GD gesluisd" (D 79). Echter, op 9 juli wordt de "Tussenrapportage Bezuinigen=K iezen" (D 78) in de gecombineerde raadscommissie Algemene Zaken/M iddelen van M aastricht behandeld. In de toelichting op een lange lijst bezuinigingsvoorstellen staat: "D e voorgestel de maatregelen hebben geen ingrijpende gevolgen voor doelen: het project $\mathrm{H}$ artslag bij de GGD is GSB-impulsbeleid en is dus eindig." Zonder dat dit tot de GGD is doorgedrongen, wordt besloten om het budget te schrappen voor de bijdrage die het welzijnswerk levert aan $\mathrm{H}$ artslag L imburg, jaarlijks $€ 91.000$. $0 \mathrm{p} 11$ juli meldt de portefeuillehouder hierover in het $D B$ van de GGD dat de gemeente $M$ aastricht "minder geld beschikbaar zal hebben voor de GGD als geheel" (D 82). $G$ emeenten verschillen in de interpretatie van de gemeenschappelijke regeling op dit punt. De kleinere gemeenten vrezen dat zij "de consequenties van het eenzijdige besluit van de gemeente $M$ aastricht zullen moeten dragen." De interim directeur van de G GD pleit voor zorgvuldigheid en "regelmatig en structureel overleg met de gemeente $M$ aastricht". D aarop geeft de wethouder van M aastricht aan de beslissing nogmaals te bezien. Terwijl de portefeuillehouder van Valkenburg meldt dat $\mathrm{H}$ artslag Limburg opgenomen is in de begroting, spreekt zijn collega uit Eijsden zijn zorg uit over de financiële impact van de lopende projecten waaronder $\mathrm{H}$ artslag Limburg. De portefeuillehouder van $\mathrm{M}$ aastricht wijst hem erop dat er tussentijdse evaluaties gedaan worden, op basis waarvan besloten kan worden deze projecten al dan niet te continueren. Wel "zal nage gaan dienen te worden hoe deze projecten in de reguliere structuur ingebed zouden kunnen worden" (D 82). Bekend is dan dat cijfers van het RIVM pas in het voorjaar van 2004 beschikbaar zullen zijn.

Als enkele weken later voor de GGD duidelijk wordt dat de subsidie uit het Grote Stedenbeleid (GSB) voor $\mathrm{H}$ artslag Limburg geschrapt is, en tevens op landelijk niveau er geen duidelijkheid komt over continuering van de financiering voor praktijkondersteuning, wordt besloten om de beschikbare energie in te zetten op de gemeenten, het welzijnswerk en het ziekenhuis. D e samenwerking van $\mathrm{H}$ artslag Limburg met de huisartsen wordt afgerond. In september lopen verschillende processen langs elkaar. D e GGD directeur redeneert dat een besluit over $\mathrm{H}$ artslag Limburg pas wordt genomen door goedkeuring door $D B$ en algemeen bestuur $(A B)$ van het productenboek van de GGD later dat jaar (D 86, D 96). In zijn ogen is cruciaal de positionering van $\mathrm{H}$ artslag 
binnen het verplichte W CPV-pakket. Op 19 september wordt de GGD getipt dat $\mathrm{H}$ artslag Limburg vermeldt staat als 'best practice' in de concept-preventienota van VW S (D 90) en de G GD zorgt per omgaande voor verspreiding hiervan naar haar samenwerkingspartners (D 92, D 94).

D oor toeval is de GGD niet op tijd op de hoogte van de bijeenkomst van de raadscommissie Breed W elzijn op 29 september: de uitnodiging is blijven liggen bij de ongeopende post. $\mathrm{H}$ et bezuinigingsvoorstel op $\mathrm{H}$ artslag Limburg wordt op 29 september niet besproken daar er geen vragen over gesteld worden (D 95). D e directeur van het welzijnswerk bericht hierover op 2 oktober de projectleider van de GGD. In een spoedoverleg van deze met de directeur van de GGD blijkt dat enkele portefeuillehouders voorgesteld hebben om in het productenboek $\mathrm{H}$ artslag als zogenoemd 'plusproduct', en dus rijp voor bezuiniging, te laten labelen ( $D$ 88). D e directeur heeft dit bestreden, en gewezen op (inter)nationale erkenning en het lokale belang van $\mathrm{H}$ artslag Limburg. In het $\mathrm{D} B$ is afgesproken om de positie van $\mathrm{H}$ artslag Limburg te bespreken bij de presentatie van het concept-productenboek op 15 oktober. In het overleg met de projectleider beslist de directeur dat géén protestsignaal over de bezuiniging wordt afgegeven. In zijn ogen is de relatie met de gemeente $M$ aastricht gespannen vanwege een aantal belangrijkere dossiers (fusie en de herziening van de tariefstructuur vanwege de omschakeling van input- naar productbegroting). O ok de suggestie om een protest van GGD en welzijnswerk gezamenlijk te laten klinken wordt afgewezen (D 97).

D esalniettemin zijn er de volgende dagen contacten tussen GGD -medewerkers, ambtenaren en het welzijnswerk (D 98). D e GGD legt aan de ambtenaar van gemeente $\mathrm{M}$ aastricht voor dat de voorgenomen bezuiniging op welzijnswerk het einde dreigt te betekenen voor $\mathrm{H}$ artslag Limburg, dit in flagrante tegenspraak met de recent aangenomen nota. Een paar dagen later blijkt wat voor subtiele nuances kunnen zitten achter een vrij algemene uitspraak. D e gemeente $M$ aastricht verklaart dat de belofte van afgelopen maart 2003 dat er niet bezuinigd zou hoeven worden op het GGD-budget niet geldt voor financieringsstromen die buiten de reguliere GGD -begroting vallen, zoals de gelden uit het GSB. $H$ artslag blijkt, zonder overleg met de GGD, geschrapt te zijn van de lijst "doorlopende GSB-projecten". D e totale bezuiniging komt daarmee op $€ 160.000$, nagenoeg het totale budget voor uitvoering van $\mathrm{H}$ artslag Limburg in de gemeente $M$ aastricht. GGD -medewerkers kunnen hier niets meer aan veranderen (D 98). Twee dagen later wijst de directeur van de GGD een voorstel voor een nieuwsbrief over $\mathrm{H}$ artslag af: "te gevoelig in de huidige situatie" (D 99). Wel wordt samen met de projectleider een gesprek gepland met de portefeuillehouder die in het D B de meest kritische geluiden laat horen, met name over "steeds maar toenemende financiële claims van $\mathrm{H}$ artslag Limburg". D it gesprek vindt plaats op 13 oktober, een week later (D 101). Conclusie van dit gesprek is dat 
het beeld van de portefeuillehouder grotendeels blijkt te berusten op foutieve informatie, o.a. aangereikt door afdeling financiën van de GGD (!) en mede gebaseerd op misinterpretatie van bijdrage van de $\mathrm{H}$ artstichting. D e misverstanden blijken opgelost te kunnen worden. De portefeuillehouder concludeert: "D e H artslag medewerkers moeten gewoon doorgaan. Aan de inhoud van het project wil ik helemaal niets afdoen, dat is prima. Wel moet de GGD veel duidelijker aangeven dat het om een belangrijk regulier product gaat. Inbedding in het reguliere beleid van de GGD , daar heeft het aan ontbroken."

Portefeuillehouder en GGD -directeur bevestigen dat $\mathrm{H}$ artslag Limburg thuis hoort in het basispakket van de GGD. Komende 15 oktober zal dit zo aan raadsleden en AB-leden gepresenteerd worden.

D e dag daarop, op 14 oktober 2003, bespreekt de M aastrichtse raad de bezuiniging op de bijdrage vanuit het welzijnswerk aan $\mathrm{H}$ artslag Limburg. $\mathrm{O} p$ vragen antwoordt de plaatsvervangend portefeuillehouder dat "dit gezondheidsbeleid betreft en dus thuis hoort binnen de G GD -begroting" (D 102). D e oppositie dringt niettemin aan op het schrappen van de bezuiniging op $\mathrm{H}$ artslag Limburg. D e plaatsvervangend portefeuillehouder reageert: “W ij willen met de GGD contractafspraken maken, waardoor de dienst bij het project $\mathrm{H}$ artslag de rol van ons overneemt. W ij verwachten daarmee de doelstelling van het project overeind te houden en tevens een geringe besparing te bereiken. (..) Wij zijn er van overtuigd dat de GGD door de inhoud van haar werk de functie van het welzijnswerk goedkoper kan vervullen". U iteindelijk keurt de gemeenteraad het bezuinigingspakket definitief goed.

D e dag daarna, 15 oktober 2003, houdt de GG D een grote bijeenkomst voor het Algemeen Bestuur en raadsleden waarop zij het nog te accorderen Productenboek 2004 feestelijk aanbeveelt. In een van de presentaties wordt uitgebreid ingegaan op de redenen achter het GGD -voorstel om de "methode van $\mathrm{H}$ artslag Limburg" als nieuwe standaard binnen wettelijk product GVO op te nemen. In de tussentijd wordt in de periode van september tot december 2003 constructief samengewerkt tussen G GD en azM (D 106). D e subsidieaanvraag bij het Fonds O GZ wordt gehonoreerd en met dit extraatje op zak onderhandelt de GGD met het azM over de omvang van de inzet van het azM . Vanuit de GGD is er verder intensief contact met de gemeente $M$ argraten (D 105). $0 p$ de presentatie voor de raadscommissie op 4 juni was er veel kritiek vanuit het CDA: "H artslag Limburg is weggegooid geld". D e gemeente heeft daarop de conceptbegroting aangepast door de GGD ondersteuningsfunctie los te koppelen van de uitvoeringsactiviteiten. D e nota wordt met hulp van de GGD aangepast aan kritiek uit de commissie (D 104). D ankzij de ambtenaar welzijn en volksgezondheid wordt samenhang met de zgn. 'breedtesportimpuls' (landelijke subsidieregeling) gereal iseerd. D eze ambtenaar weet het totale voorgestel de investeringsbedrag te verruimen van $€ 36.000$ naar $€ 51.000$. 
In de periode september tot oktober wordt op landelijk niveau scherp gereageerd op de concept-preventienota van VW S. Commentaar van VN G en GGD $N$ ederland is dat "landelijk en gemeentelijk beleid onvoldoende op elkaar aansluiten; landelijke zijn er wel meer ambities, maar voor de uitvoering door gemeenten is geen extra geld. Bovendien is er onvoldoende aandacht voor participatie van gemeenten en 'targetting' op LSES-groepen". W im Kuiper, directeur van de V N G: "Ik mis het gevoel in politiek bestuurlijk N ederland voor de urgentie van een preventief volksgezondheidsbeleid" (D 89, D 110). Eind oktober, bij het verschijnen van de definitieve VW S-nota wordt die kritiek nog eens herhaald.

O 6 november 2003 brengt de Inspectie voor de Volksgezondheid een algemeen toezichtbezoek aan de GGD. H et rapport vermeldt: "D e GVO functie binnen de GGD is uitzonderlijk goed ontwikkeld" en concludeert: "U it de ge sprekken kwam naar voren dat de relatie met de gemeentes stroef verloopt. (...) $\mathrm{H}$ ier ligt een taak voor de GGD als gemeentelijke instelling om de gemeentebestuurders op een politiek sensitieve manier duidelijk te maken wat het belang is van de activiteiten van de GGD." (D 114).

In een overleg op 19 november tussen GGD en ambtenaren komt naar voren dat er bij de gemeente $M$ aastricht iets niet goed gegaan is (D 112). D e ambtenaren geven aan dat de bezuiniging van 91 mille "eigenlijk niet had gemogen" en adviseren de GGD een brandbrief te sturen naar de gemeenteraad. D e GGD medewerker informeert de directeur. 0 p 24 november 2003 bespreken projectleider, directeur en afdelingsmanagers opnieuw de handelingsopties (D 116). D irecteur geeft aan dat de fusie en de daarbinnen lopende financiële zorgen momenteel zijn belangrijkste thema's zijn. Besloten wordt twee brandbrieven uit te laten gaan naar de gemeente M aastricht: één vanuit de GGD en één vanuit de partners van universiteit en academisch ziekenhuis. D ie brieven gaan uit, maar de reactie erop lijkt minimaal. $0 p 4$ december concludeert de directeur "dat de wethouder $M$ aastricht niet terug zal willen komen op de begroting die half oktober door de Raad is vastgesteld. O plossingen kunnen alleen nog binnen dat kader gezocht worden." (D 121). O p 11 december besluit het D B naar aanleiding van de brieven tot het instellen van een werkgroep die de bezuinigingen rondom $\mathrm{H}$ artslag Limburg in kaart moet brengen (D 123).

H eel anders dan de samenwerking met de gemeenten loopt de samenwerking tussen GGD en het azM . O ok het azM moet bezuinigen maar in een overleg met de GGD op 29 oktober 2003 meldt het betrokken management: "het azM heeft ook een visie op de noodzakelijke vernieuwing en dit project (bedoeld wordt het $\mathrm{H}$ artVaatC entrum i.o. inclusief de component van $\mathrm{H}$ artslag) past nadrukkelijk in die gewenste vernieuwing." (D 106). D ie vernieuwing blijft in 2003 en 2004 gevrijwaard van bezuiniging. 


\subsubsection{Gebeurtenissen in 2004: een nieuwe werkelijkheid}

O p 5 januari 2004 ondertekenen G GD en azM een contract met daarin opgenomen uitbreiding van de samenwerking (fte inzet van 1,0 naar 1,7), voor de periode jan.2004 - juli 2006 (D 126); dit is mede mogelijk gemaakt door subsidie van het Fonds $O G Z$. M et dit contract is een nieuw niveau van verankering van de bestuurlijke samenwerking tussen GGD en azM bereikt. O p 12 januari 2004 komt de tijdelijke werkgroep van G GD, welzijnswerk en ambtenaren van $M$ aastricht en Valkenburg bijeen (D 127). Gemeente $M$ aastricht benadrukt haar wens om aangepast product $H$ artslag af te willen nemen. GGD stelt compromis voor waarin $€ 65.000$ van de $€ 160.000$ mille bezuiniging opgevangen wordt. $D$ irecteur van het welzijnswerk beticht de gemeente van "onbehoorlijk bestuur als het gaat om het vaststellen van gemeentelijk gezondheidsbeleid en enkele maanden later weghalen van de benodigde financiën. Behalve bestuurlijk vind ik beslist dat dit traject ook ambtelijk niet goed is voorbereid". D e ambtenaren volksgezondheid geven aan geen grip te hebben op de bezuinigingsprocessen. $D$ e ambtenaar van $M$ aastricht zegt toe intern te zoeken naar mogelijk resterende middelen voor 2004 en vooral prioritering te willen realiseren voor begroting 2005. D e GGD gaat opnieuw haar productenboek en begroting voor 2005 aanpassen en proberen zoveel als mogelijk $\mathrm{H}$ artslag Limburg daarbinnen vorm te geven.

D e tweede bijeenkomst van de werkgroep vindt plaats op 17 februari 2004 (D 136). D e gemeente M aastricht meldt géén extra middelen beschikbaar te hebben; maar, de gemeente wil het product ondanks de bezuinigingen gerealiseerd zien. D e GGD verwijt daarop de gemeente dat zij geen duidelijke keuzes maakt. D e directeur welzijnswerk: "W ij zijn op het verkeerde been gezet: de GGD zou gaan inkopen, maar nu blijkt dat de GGD niet kàn inkopen." Twee dagen later meldt de GGD -directeur aan het D B: "dat het niet anders kan dat in 2004 $\mathrm{H}$ artslag wordt afgebouwd, maar dat wij nu over 2005 praten en bezig zijn aan een nieuw model GVO." H et GGD-management krijgt de taak om een notitie te maken. $D$ at de GGD het desalniettemin moeilijk heeft in de relatie tot de gemeente $M$ aastricht blijkt kort daarop: op 15 maart keurt de raadscommissie de begroting voor 2004 af, wegens "onvoldoende financiële transparantie" (D 147). $D$ e bezuinigingen door de gemeente $M$ aastricht blijven niet op zich zelf staan. Sinds november blijkt de gemeente Valkenburg te willen bezuinigen op de GGD en noemt daarbij ook H artslag Limburg, waarmee het tekort oploopt tot $€ 180.000$ (D 108). O p 24 maart volgt een formele brief van de gemeente Eijsden: "N u een aantal gemeenten te kennen heeft gegeven geen ( $M$ aastricht) of een veel geringere ( $M$ argraten en Valkenburg a/d/ Geul) bijdrage te willen verlenen ten behoeve van $\mathrm{H}$ artslag kan het niet zo zijn dat $\mathrm{M}$ eerssen en Eijsden hierin buitenproportioneel gaan bijdragen." (D 148). 
Tegelijkertijd nemen de zaken in M argraten hun eigen loop. 0 p 24 maart 2004 wordt in de raadscommissie fel gediscussieerd over $\mathrm{H}$ artslag Limburg (D 149). GGD -medewerkers voeren een intensieve lobby richting leden van de raadscommissie met actieve hulp van ambtenaren van de gemeente $M$ argraten. $0 p$ verzoek van het CD A wordt allerlei detailinformatie via de ambtenaar van $M$ argraten bij de GGD opgevraagd en uiteindelijk ook aangeleverd (D 153, D 155). Toegestaan wordt dat de GGD dit in de commissie komt toelichten op 21 april. $\mathrm{D}$ an krijgt $\mathrm{H}$ artslag Limburg plots wind in de rug. Begin april meldt het RIVM vertrouwelijk dat er fraaie effectresultaten zijn gevonden. D e projectleider neemt hierover contact op met de Volkskrant (D 157). Gekozen wordt voor een timing gelijktijdig met de presentatie op $\mathrm{N}$ ationaal C ongres Volksgezondheid op 15 april. Die dag brengt de Volkskrant het nieuws op de voorpagina en de GGD brengt de 'aantoonbare resultaten' onder de aandacht van bestuurders en ambtenaren (D 159). Voor de vergadering van de raadscommissie van $M$ argraten komen de cijfers nog net op tijd (D 165). H et lokale CD A blijft kritisch: "H oezo verplichte basistaak? En hoe kan het dat de wethouder $M$ aastricht in de krant 'juicht' over de successen van $\mathrm{H}$ artslag, terwijl in de begroting van de GGD blijkt dat juist M aastricht haar bijdrage reduceert tot nul?". M aar uiteindelijk antwoordt het CD A evenals de andere partijen overtuigd te zijn van de resultaten. D e commissie stemt in met nota Lokaal G ezondheidsbeleid 2003-2007 met daarin opgenomen $€ 48.000$ voor lokale gezondheidsbevordering, inhoudende een continuering en zelfs flinke uitbreiding van de lokale gezondheidsbevordering. 0 p 11 mei verleent vervolgens de Raad van de gemeente $M$ argraten goedkeuring aan zowel begroting 2004, het productenboek, als de N ota Lokaal Gezondheidsbeleid (D 169).

D it succes brengt echter geen definitieve oplossing. G edurende de lente en zomer vinden moeizame onderhandelingen plaats met de gemeenten over het product lokale gezondheidsbevordering in de begroting van 2005. Begin juni stapt de portefeuillehouder van $M$ aastricht op na aanhoudende conflicten met de gemeenteraad (D 172). 0 p 22 juli 2004 maakt de directeur tegelijk met de komst van de opvolger bekend dat de GGD zwaar in de problemen zit: door verschillende oorzaken is er een tekort van acht ton (D 178). Boodschap van het bestuur is: "G ezond de fusie ingaan en dus terug naar de kerntaken; de wettelijke eisen mogen hiermee niet in gevaar komen. H ieronder valt 0.a. de GVO ... ". M aar de GGD moet wel "versoberen". Voor H artslag Limburg betekent dit uiteindelijk dat op een budget van $€ 419.000$ in totaal $€ 180.000$ moet worden ingekrompen ( $€ 90.000$ uit stop GSB-subsidie en $€ 90.000$ uit bezuiniging op regulier GGD budget; D 142, zie ook tabel 4.1, paragraaf 4.2). H et product 'lokale gezondheidsbevordering' komt in de plaats van $\mathrm{H}$ artslag Limburg en wordt meegenomen in de fusieplannen. Echter, van de vrijwilligers in de oorspronkelijke werkgroepen van $\mathrm{H}$ artslag Limburg is dan al afscheid genomen. De 
als maar voortdurende onzekerheid over de toekomst valt aan hen moeilijk uit te leggen (D 130).

\subsubsection{Het naspel: de gebeurtenissen in 2005}

O p 20 januari 2005 sluiten VN G, G GD N ederland en N IGZ een convenant ter ondersteuning van gezondheidsbevordering op lokaal niveau. D e regio ZuidLimburg wordt gekozen als een van de drie voorbeeldregio's waar men een vierjarige samenwerking mee wil opbouwen (D 192, D 193, D 205).

Begin april 2005, een jaar na het bekend worden van de RIVM -cijfers, worden ook de uitkomsten bekend van de kosteneffectiviteitstudie (Ronckers, 2006b). In deze studie is berekend hoeveel levensjaren zijn gewonnen op basis van het gemeentelijke deel van $\mathrm{H}$ artslag Limburg en welke kosten in euro's nodig waren om die gezondheidswinst te behalen. 0 ok deze cijfers blijken gunstig: met een schatting van rond de $€ 3500$ per gewonnen levensjaar blijkt $\mathrm{H}$ artslag Limburg ver onder de binnen de gezondheidszorg al gemeen geaccepteerde grens van $€ 20.000$ per gewonnen levensjaar te liggen. 0 p 12 april worden de resultaten nog eens gepresenteerd voor het Algemeen Bestuur van de GGD, waarbij $M$ aastricht en Valkenburg opmerken "het jammer te vinden dat nu slechts zo beperkt vorm gegeven wordt aan gezondheidsbevordering" (D 197).

In de loop van juli 2005 keuren de betrokken 19 gemeenten het fusiebesluitdocument voor het samengaan van de drie Zuid-Limburgse GGD 'en goed.

D iezelfde maand verwoordt de directeur generaal volksgezondheid van VW S zijn mening over het belang van implementatie van best practices: "N eem nou zo'n project als $\mathrm{H}$ artslag Limburg. D at werkt. D us laten ze dat overal gaan uitvoeren en niet komen met zaken als 'not invented here' (D 207).

\subsection{Conclusie}

U it de chronologische beschrijving van de casus blijkt dat het verankeringsproces min of meer gescheiden per echelon verlopen is. Vooral op het vlak van het gemeentelijke gezondheidsbeleid zijn veel gebeurtenissen geregistreerd. Verder is in de beschrijving herkenbaar dat een groot aantal bevorderende en belemmerende factoren een rol heeft gespeeld bij het proces van bestuurlijke verankering. D e belangrijkste hiervan op landelijk niveau zijn de nieuwe W CPV, de kernboodschap van de VTV 2002 en de bezuiniging op het gemeentefonds; anders gezegd: het landelijke beleid schept nieuwe verplichtingen en richtlijnen voor bestuurders en professionals op lokaal niveau, onder het gelijktijdig korten op de algemene pot waaruit die taken gefinancierd moeten worden. 
D e belangrijkste factoren die op lokaal niveau opvallen zijn een lokale context waarin een stroeve relatie, financiële tegenvallers voor gemeenten en GGD en een fusietraject spelen. Binnen de dimensie verandermanagement valt op dat er weliswaar veel acties zijn ondernomen, maar de vraag blijft in hoeverre hier effectief gehandeld werd. In de volgende hoofdstukken komt een systematische analyse van die factoren aan bod. 


\section{Hoofdstuk 5 Externe factoren}

\section{$5.1 \quad$ Inleiding}

In dit hoofdstuk volgt een nadere analyse van de twee factoren die gedefinieerd zijn binnen de dimensie 'externe factoren'. H ieronder volgt eerst een algemene introductie. Vervolgens gaat paragraaf 5.2 over 'overheidsbeleid', en paragraaf 5.3 behandelt de factor 'opstelling financiers'. Binnen deze factoren komt eerst de feitenbeschrijving aan bod (het eerste deel van de tijdreeksanalyse, weergegeven in staafdiagrammen); dan volgt via triangulatie het resultaat uit interviews en enquêtes (het tweede en derde deel van de tijdreeksanalyse, zie ook paragraaf 3.4.3). Zoals eerder aangegeven betreft de analyse voornamelijk het perspectief van het gemeentelijke deel van $\mathrm{H}$ artslag Limburg omdat hier de meeste gebeurtenissen plaatsvonden; het perspectief van de samenwerking tussen GGD en huisartsen en academisch ziekenhuis komt slechts summier aan bod. Paragraaf 5.4 besluit met een conclusie.

Voor het eerste deel van de tijdreeksanalyse, de feitenbeschrijving, zijn de aantallen 'gebeurtenissen' per factor geteld en beoordeeld als positief of negatief, respectievelijk bevorderend dan wel belemmerend voor de bestuurlijke verankering (zie 3.4.3). In figuur 5.1 is het totaal aantal gebeurtenissen van de dimensie externe factoren per kalenderjaar weergegeven. In de figuren 5.2 en 5.3 is dit opgesplitst tussen de beide deelfactoren. Ter onderscheiding van de dimensie lokale context gaat het hier om de landelijke componenten.

Figuur 5.1 maakt duidelijk dat in de meeste jaren zowel bevorderende (positief) als belemmerende (negatief) gebeurtenissen gescoord zijn. In 2003 vonden de meeste gebeurtenissen plaats. De uitsplitsing in de figuren 5.2 en 5.3 geeft een opvallend beeld: de gebeurtenissen binnen de factor overheidsbeleid worden merendeels positief, dus bevorderend ingeschat, terwijl de gebeurtenissen binnen de factor opstelling financiers overwegend negatief, dus belemmerend, worden beoordeeld.

Voorzichtigheid bij de interpretatie van deze en de in latere hoofdstukken volgende staafdiagrammen is op zijn plaats. H et aantal gebeurtenissen per jaar geeft wel een indicatie, maar hoeft in principe nog niets te zeggen over de impact en de richting van de gebeurtenissen. Bovendien kan er sprake zijn van selectiebias (zie 3.4). U it figuur 5.1 kan bijvoorbeeld niet geconcludeerd worden dat de bevorderende en belemmerende gebeurtenissen in 2003 elkaar neutraliseerden, of dat het in 2004 'beter ging' omdat de negatieve score lager ligt. Essentieel is de inhoud, per factor of per zelfs thema binnen die factor. Dit kwalitatieve aspect geldt in nog sterkere mate voor de interviews: daar zijn dan ook geen kwantita- 
tieve figuren van gemaakt. Bij de analyse van de data uit de enquêtes blijft om soortgelijke reden als bij de feitenbeschrijving de presentatie beperkt tot fre quenties (zie 3.4.3). Voor de leesbaarheid wordt figuur 5.3 in de betreffende paragraaf herhaald.

\section{Externe factoren}

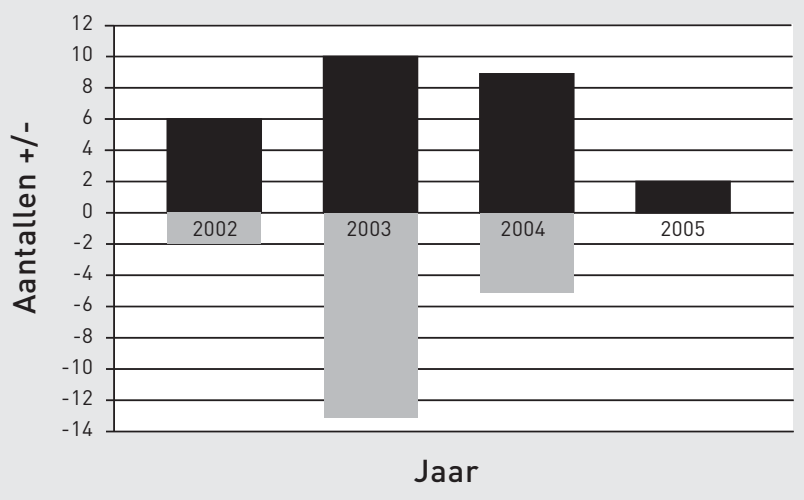

Figuur 5.1 Totaal aantal gebeurtenissen binnen de dimensie Externe Factoren van de feitenbeschrijving

2a. Overheidsbeleid

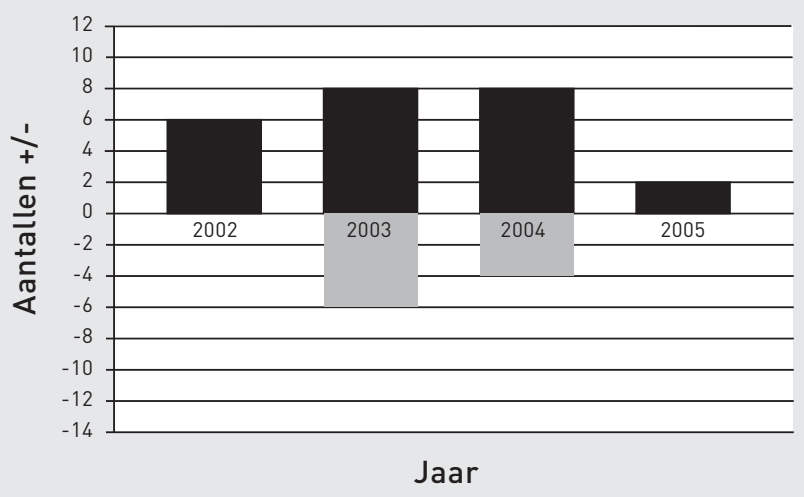

Figuur 5.2 Aantal gebeurtenissen van de factor Overheidsbeleid 
2b. Opstelling financiers

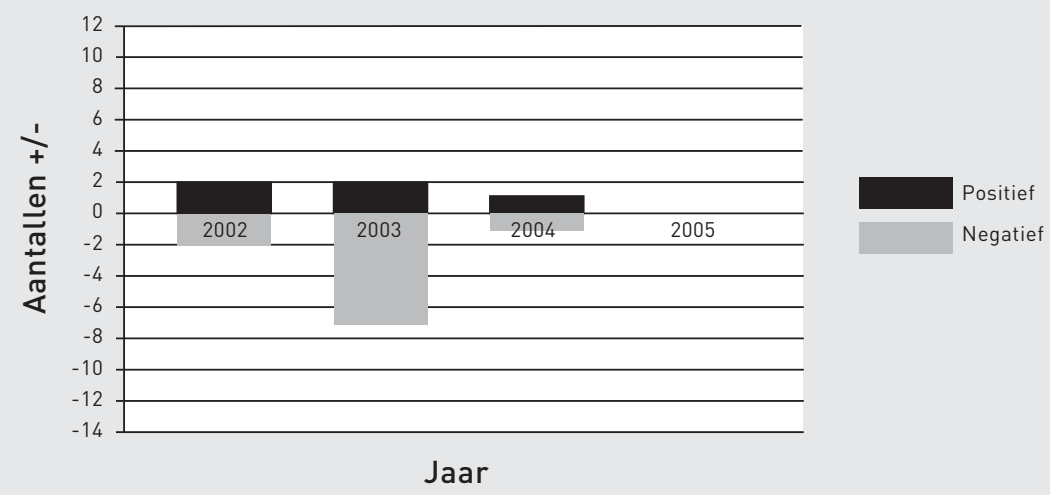

Figuur 5.3 Aantal gebeurtenissen van de factor Opstelling financiers

\subsection{Overheidsbeleid}

\subsubsection{Overheidsbeleid: resultaten uit de feitenbeschrijving}

D e positieve gebeurtenissen van figuur 5.2 bestonden vooral uit de aanscherping van het wettelijk kader, de WCPV, de verschijning van het RIV M -rapport met de kernboodschap om meer te investeren in preventie (van 0 ers, 2002), gevolgd door de preventienota van VW S (oktober 2003), de reacties op beide notities van kamerfracties en landelijke organisaties (VN G, GGD N ederland, N IGZ) in 2003 en 2004 met de vraag om meer middelen, en de inrichting van het landelijke programma academische werkplaatsen vanaf eind 2004 (D 187). Positief is ook dat $\mathrm{H}$ artslag Limburg zowel in de VTV als in de preventienota van VWS specifiek vermeld wordt. D it laatste mede dankzij eerdere acties van de GGD waarbij contacten gelegd werd met VW S-ambtenaren, wat o.a. leidde tot een werkbezoek van een VW S-delegatie aan M aastricht in mei 2002 (zie 8.3.1)(D 12, D 13).

D e negatieve scores uit figuur 5.2 betroffen de volgende gebeurtenissen. Zowel de moties Kant (D 24) en Tonkens (D 135), als de voorstellen van de landelijke organisaties halen het niet. Commentaar van VN G en G GD N ederland is dat "landelijk en gemeentelijk beleid onvoldoende op elkaar aansluiten; landelijke zijn er wel meer ambities, maar voor de uitvoering door gemeenten is geen extra geld. Bovendien is er onvoldoende aandacht voor participatie van gemeenten en 'targetting' op LSES-groepen". W im Kuiper, directeur van de V N G : "Ik mis het gevoel in politiek bestuurlijk $\mathrm{N}$ ederland voor de urgentie van een preventief 
volksgezondheidsbeleid" (D 89). D eze constatering is tekenend voor de lastige positie waar GGD'en zich in bevinden. Enerzijds wordt samen met gemeenten gepleit voor extra geld, anderzijds levert het uitblijven van landelijke financiering gemeenten ook het alibi om zelf geen investering te doen. D aarom is deze gebeurtenis gelabeld als belemmerend voor de bestuurlijke verankering. $\mathrm{N}$ egatieve scores betreffen daarnaast $0 . \mathrm{a}$. het uitblijven van de verlenging van het $N$ ationaal Contract $O$ penbare G ezondheidszorg (D 35), het pleidooi van VNG en GGD N ederland voor bestuurlijke opschaling (een stimulans voor fusies)(V N G , 2004), en een rapport van de Inspectie dat concludeert dat "de gemeentelijke betrokkenheid lijkt verbeterd te zijn ten opzichte van 1995", maar waarin de Inspectie geen aandacht heeft geschonken aan gezondheidsbevordering (D 71). D e trend naar bestuurlijke opschaling krijgt zijn weerklank in de regio Zuid-Limburg: vanaf begin 2003 wordt daar een fusie tussen de drie GGD'en in gang gezet (D 74); in paragraaf 6.3.3 wordt daar nader op ingegaan.

\subsubsection{Overheidsbeleid: resultaten uit interviews en enquêtes}

U it triangulatie met interviews blijkt dat de positieve invloed van het RIV M rapport, de preventienota en de vernieuwde W CPV door bestuurders wordt bevestigd. Tegelijkertijd wordt echter naar voren gebracht dat er aan eventuele ambities steeds financiële beperkingen hangen; deze kanttekening klinkt in 2004 nog scherper dan in 2003.

$>$ "Landelijke rapporten zijn bevorderlijk. Uit recente rapporten bleek dat onze regio een gezondheidsachterstand heeft ten opzichte van de rest van Nederland, wat speciaal geldt voor bepaalde groepen. Dat zet ons toch aan om er juist hier wat aan te doen." (57;13.08.2003)

"We krijgen nu ook als plicht om een gezondheidsbeleid te ontwikkelen. Dus gemeenten zijn ijverig doende om dat ook van de grond te krijgen, maar het blijft dan beperkt tot een mooi verhaal, en de gemeenten zijn niet bereid om financieel heel ver te gaan daarin." (55;14.08.2003)

"Wij zijn in die positie gedwongen dat wij dus lokaal gezondheidsbeleid moeten gaan voeren. Aan de andere kant zou het Rijk de eerste aanzetten geven, maar die hebben dat nagelaten vanwege de kabinetswisselingen." (55;28.07.2004)

H et beeld dat landelijke inhoudelijke invloeden positief beoordeeld worden maar dat de rekening daarvan door het kabinet te veel bij de gemeenten neergelegd wordt, wordt bevestigd door de data uit de enquêtes (zie tabel 5.1 en 5.2). 
Aanvullend komt nog naar voren dat ook het beleid van zorgverzekeraars voornamelijk als belemmerend voor de samenwerking wordt beoordeeld.

\begin{tabular}{|c|c|c|c|c|}
\hline $\begin{array}{l}\text { Overheidsbeleid } \\
\text { Item uit vragenlijst }\end{array}$ & 2003 & & & \\
\hline Oordeel over: & 'bevorderend' & 'neutraal' & 'belemmerend' & totaal (n) \\
\hline $\begin{array}{l}\text { de invloed van de WCPV } \\
\text { de invloed van recente landelijke } \\
\text { rapporten (o.a. van RIVM) } \\
\text { de invloed van het huidige } \\
\text { kabinetsbeleid } \\
\text { de invloed van het beleid van } \\
\text { zorgverzekeraars }\end{array}$ & $\begin{array}{l}68 \\
60 \\
3 \\
11\end{array}$ & $\begin{array}{l}29 \\
29 \\
23 \\
27\end{array}$ & $\begin{array}{l}3 \\
11 \\
73 \\
62\end{array}$ & 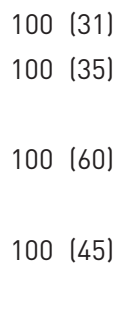 \\
\hline $\begin{array}{l}\text { Overheidsbeleid } \\
\text { Item uit vragenlijst }\end{array}$ & 2004 & & & \\
\hline Oordeel over: & 'bevorderend' & 'neutraal' & 'belemmerend' & totaal $(\mathrm{n})$ \\
\hline $\begin{array}{l}\text { de invloed van de WCPV } \\
\text { de invloed van recente landelijke } \\
\text { rapporten (o.a. van RIVM) } \\
\text { de invloed van het huidige } \\
\text { kabinetsbeleid } \\
\text { de invloed van het beleid van } \\
\text { zorgverzekeraars }\end{array}$ & $\begin{array}{l}54 \\
58\end{array}$ & $\begin{array}{l}39 \\
31\end{array}$ & $\begin{array}{l}82 \\
77\end{array}$ & $\begin{array}{ll}100 & (26) \\
100 & (26) \\
100 & (34)\end{array}$ \\
\hline
\end{tabular}

Tabel 5.1 Factor Overheidsbeleid:oordeel van respondenten (percentages van het totaall over de invloed van het landelijke overheidsbeleid op de samenwerking met/binnen Hartslag Limburg. 


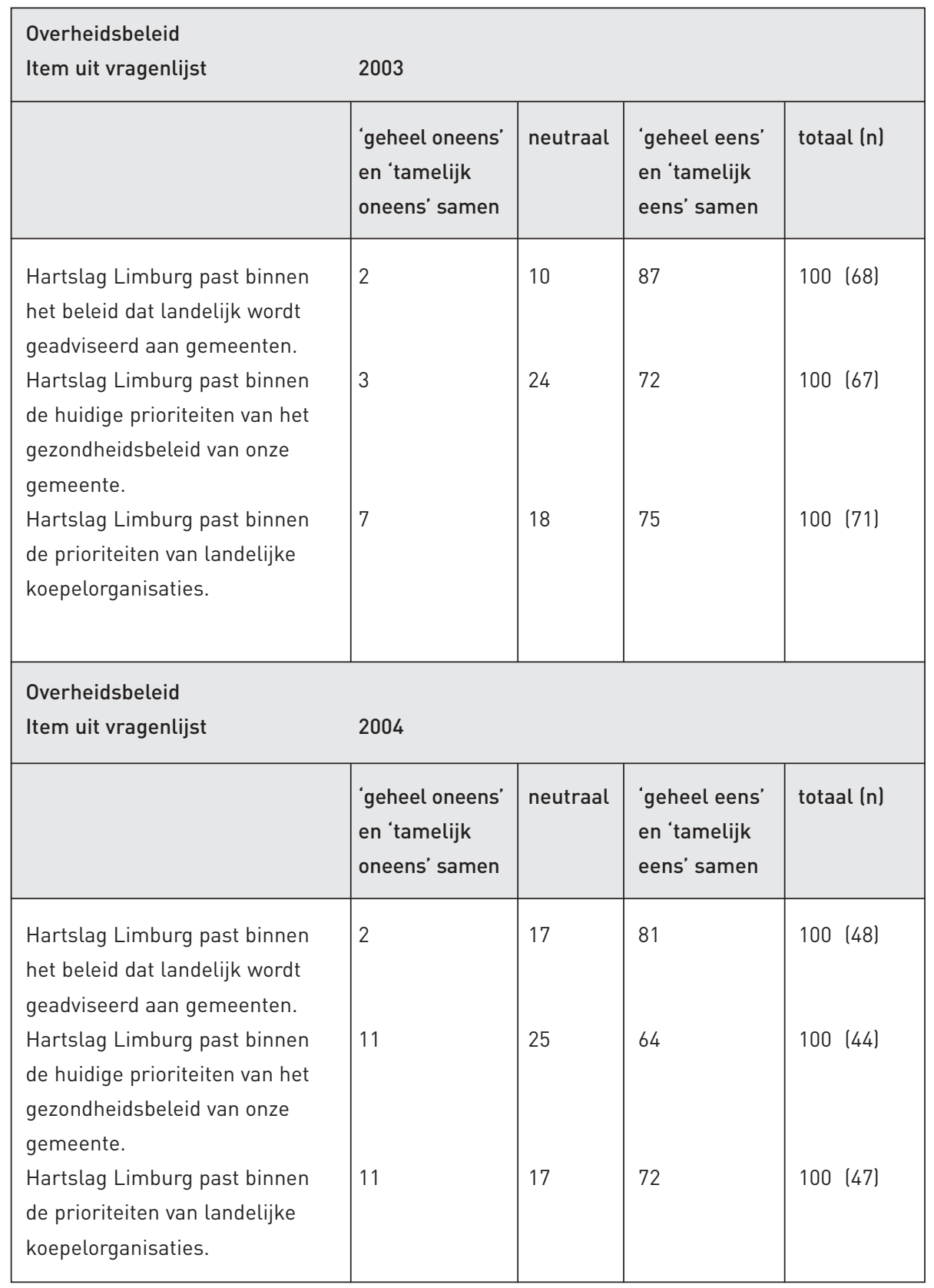

Tabel 5.2 Factor Overheidsbeleid: oordeel van respondenten (percentages van het totaal) over de inpasbaarheid van Hartslag Limburg in landelijke en lokaal overheidsbeleid. 


\subsubsection{Overheidsbeleid: conclusie}

Samenvattend luidt de conclusie dat de factor 'overheidsbeleid' in de casus in potentie een positieve, bevorderende invloed had, maar dat die potentie onvoldoende gerealiseerd is. Dit komt doordat vanuit het ministerie, RIVM en de Inspectie, wel aangegeven wordt wat er moet gebeuren, maar nauwelijks hoe. D e discussie tussen de landelijke en lokale overheden verschuift van de urgentie om lokaal te handelen naar wie dat moet betalen. D aarmee blijkt de kracht van deze factor nauw verbonden met de factor 'opstelling van (landelijke) financiers'.

\subsection{Opstelling financiers}

\subsubsection{Opstelling financiers: resultaten uit de feitenbeschrijving}

2b. Opstelling financiers

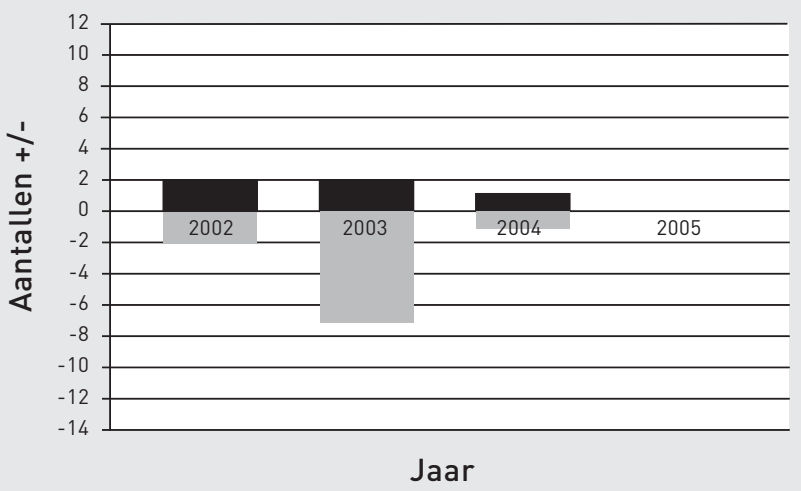

Figuur 5.3 Aantal gebeurtenissen van de factor Opstelling financiers lbinnen de dimensie Externe Factoren/.

De positieve scores in figuur 5.3 betreffen pleidooien van enerzijds de minister ("investeren door gemeenten is noodzakelijk")(D 17) en anderzijds kamerfracties (vragen aan de minister om een hoger budget voor preventie)(D 24, D 27, D 36). Echter, over deze positief gelabelde uitspraken hangt de schaduw van de negatieve scores. D ie bestaan namelijk uit de acties van deels dezelfde actoren en houden bezuinigingen in. In dezelfde al inea waarin de minister gemeenten aanspreekt op de noodzaak van extra investeringen, geeft hij aan zelf "thans geen ruimte te zien voor extra middelen" (D 17). Cruciaal zijn verder de kabinetsbe- 
zuinigingen op het gemeentefonds van 2003, het uitblijven in 2003 en 2004 van landelijke duidelijkheid over de financiering van de praktijkondersteuners in huisartspraktijken en de aankondiging van de in de regio $M$ aastricht meest betrokken zorgverzekeraar, die aangeeft geen geld voor innovatie meer te hebben (D 33).

D e landelijke bezuiniging op het gemeentefonds treft de gemeenten hard. De gemeente $\mathrm{M}$ aastricht kondigt bijvoorbeeld begin 2003 aan 33 miljoen euro te moeten bezuinigen, te realiseren op alle gemeentelijke diensten (D 46). D e impact van deze belemmerende gebeurtenis lijkt groot, maar verdient een nuancering. D e eerste maanden van 2003 geven de gemeenten van de regio M aastricht namelijk aan dat zij de GGD bij deze bezuinigingsronde willen ontzien. Dit vanwege onder andere de al langer lopende discussie over de omvorming van de G GD -begroting (D 39). U it interviews (5.3.2) en verderop in paragraaf 6.3 (kenmerken van bedrijfsvoering), komt aan bod hoe het kon dat $\mathrm{H}$ artslag Limburg buiten deze gunstige toezegging bleek te vallen.

\subsubsection{Opstelling financiers: resultaten uit interviews en enquêtes}

U it de triangulatie komt over beide jaren (2003 en 2004) vrijwel unaniem naar voren dat lokale bestuurders, ambtenaren en professionals enerzijds de landelijke rapporten en wetgeving bevorderlijk achten, maar anderzijds het gebrek aan adequate financiering vanuit $\mathrm{D}$ en $\mathrm{H}$ aag hekelen. Sommige gemeentelijke bestuurders interpreteren dit als een signaal dat het onderwerp niet erg serieus genomen hoeft te worden, en verwachten er moeilijk draagvlak voor te kunnen verwerven in de gemeenteraad. Tekenend hiervoor is dat al in 2003, als de gemeentelijke nota's nog amper vastgesteld zijn, gesignaleerd wordt dat er geen instrumenten voor handhaving toegepast worden. $\mathrm{H}$ et is bijna alsof gezegd wordt: 'kijk hieruit blijkt dat D en $\mathrm{H}$ aag het niet belangrijk vindt, dus wat moet ik er dan mee'.

$>$ "Je wordt geacht van alles te doen op lokale volksgezondheid en dat doe je dan keurig, en dan zie je dat als Den Haag, ook door allerlei wisselingen, niet bij machte is om dat follow-up te geven, dan is het moeilijk om op lokaal niveau alle andere partijen vooral binnen de politiek te motiveren. (..) Maar men legt iets neer bij wet, maar als het gaat om de handhaving, de toetsing of we ons als lokale overheid hieraan houden, dat gebeurt niet." (43;27.08.2003)

"Het is niet zo dat de middelen altijd leidend hoeven te zijn, integendeel, maar als je dan eens iets wilt, dat anders is dan het gangbare, bijvoorbeeld als we het hebben over de preventieve gezondheidszorg, zeker met de ontwikkelingen in 
Nederland, de leefstijl van de mensen behoeft aandacht, daar moet een omslag komen. Daar is geld voor nodig. Zonder dat wordt het heel erg moeilijk, ook nog eens een keer als je in een tijd van recessie zit. Dan is het zo dat preventieve gezondheidszorg te laag op de politieke agenda staat." (43;27.08.2003)

"De WCPV stelt geen duidelijke verplichting en dus ook geen financieel kader voor deze vorm van preventie." (57;13.08.2003)

"Je zou het in de WCPV kunnen vastleggen, maar dan moet je er ook een prijskaartje aan hangen. Als je als landelijke overheid zegt dat je dit als een duidelijke preventieve activiteit ziet, dan moet je er natuurlijk ook geld bijleggen. Vanuit de landelijke kaders, gewoon belastinggeld, gemeentefonds, en dat doet men dus helemaal niet." (22;22.09.2003)

"Wij worden voor veel meer zaken verantwoordelijk gesteld, dat is op zich goed, maar de bijbehorende middelen die krijgen we dan niet, dan bestaat voor ons natuurlijk het risico dat je geafficheerd wordt als zijnde een onbetrouwbare overheid. Dat vind ik ook lastig." (43;27.08.2003)

Een jaar later is de kritiek op het gebrek aan geld uit $\mathrm{D}$ en $\mathrm{H}$ aag nog scherper. D oor één respondent wordt daarnaast een direct verband gelegd tussen de landelijke korting, de besluitvorming door gemeenten over de consequenties voor de GGD , én de bezuiniging op $H$ artslag Limburg. In één adem wordt daarbij wel een opvallend lokaal aspect genoemd: de projectfinanciering van $\mathrm{H}$ artslag Limburg. In paragraaf 6.3.2 komt dit verder aan de orde. Tegelijkertijd wordt deze lokale component voor wat betreft de opstelling van financiers ook in de enquêtes bevestigd. In 2004 antwoordt nog slechts een minderheid positief op de vraag of $\mathrm{H}$ artslag Limburg inpasbaar is binnen de geldende financieringsregels (zie tabel 5.3). O ok is een afnemend percentage respondenten positief over de opstelling van gemeenten en zorgverzekeraar als financiers.

$>$ "En als de rijksoverheid zo doorgaat met het opleggen van steeds meer taken, dan moeten daar wel de middelen tegenover staan, en dat zie ik niet gebeuren. Er is gewoon een geweldige korting, niet alleen nu, maar volgend jaar ook nog. Dan wordt het moeilijk." (57;19.10.2004)

"Bij de laatste begrotingsvergadering hebben we met een breed oog naar alle beleidsterreinen moeten gaan kijken, veelal veroorzaakt door die gigantische korting op het gemeentefonds. (..) Dus een wettelijke uitvoering van de WCPV, dat we daarvan hebben gezegd: we gaan een bepaald kortingspercentage toepassen. Nou, dat is ons niet in dank afgenomen, dat kon allemaal niet via de 
gemeenschappelijke regeling en toestanden en wat dies meer zij. In concreto is er uiteindelijk 1,5\% bezuinigd, dat is eruit gekomen, en dat heeft direct effecten gehad op onder andere Hartslag Limburg. En daar speelde ook nog het probleempje dat de financiering van Hartslag Limburg in de begroting van de gemeente ook heel nadrukkelijk als een projectfinanciering stond. Ik had een bedrag structureel WCPV en daarnaast een projectfinanciering Hartslag Limburg; nu hebben wij op de wettelijke taken een kortingsbepaling toegepast en in het verlengde daarvan is ook Hartslag Limburg meegenomen. In zijn directe relatie, ook gezien de grote van de bedragen, is Hartslag Limburg eigenlijk dubbel gepakt." (81;15.07.2004)

\subsection{Externe factoren: conclusie}

D e conclusie die getrokken kan worden over de dimensie externe factoren is dat het landelijke beleid vanaf 2002 nieuwe verplichtingen en richtlijnen voor bestuurders en professionals op lokaal niveau schept, zonder dat er duidelijkheid is over adequate financiering. G evolg is dat landelijke organisaties (V N G, G GD $N$ ederland) en het Rijk elkaar aanspreken: de hete aardappel gaat heen en weer. Begin 2003, terwijl deze discussie nog loopt, wordt er door het Rijk ook nog eens flink gekort op het gemeentefonds.

Bij lokale bestuurders roept deze ontwikkeling een breed gedeelde reactie op: de WCPV en de preventienota wil men best serieus nemen, maar zonder extra geld voor gezondheids-bevordering, en helemaal bij extra generieke bezuinigingen, voelt men zich niet in staat om een vernieuwende aan pak te implementeren. In feite verschaft de landelijke overheid gemeenten een prima alibi: de bezuinigingen op het gemeentefonds worden aangegrepen als signaal dat de oproep om gezondheids-bevordering meer gemeentelijke prioriteit te geven, niet al te serieus genomen hoeft te worden. D e GGD kan wat betreft landelijke kaders alleen enige houvast ontlenen aan de aanscherping van de WCPV en de inhoudelijke aanbevelingen van de VTV-2002.

Een soortgelijke ontwikkeling doet zich qua externe factoren voor op het vlak van de samenwerking vanuit de GGD met huisartsen en het ziekenhuis: landelijk ontbreekt er duidelijkheid over financiering en de zorgverzekeraar laat eveneens weten niet langer te beschikken over additionele middelen voor preventie. Al met al betekent dit dat het klimaat voor bestuurlijke verankering van samenwerking rondom $\mathrm{H}$ artslag Limburg door externe factoren vanaf begin 2003 flink onder druk komt te staan. 


\begin{tabular}{|c|c|c|c|c|}
\hline $\begin{array}{l}\text { Overheidsbeleid } \\
\text { Item uit vragenlijst }\end{array}$ & 2003 & & & \\
\hline & $\begin{array}{l}\text { 'geheel oneens' } \\
\text { en 'tamelijk } \\
\text { oneens' samen }\end{array}$ & neutraal & $\begin{array}{l}\text { 'geheel eens' } \\
\text { en 'tamelijk } \\
\text { eens' samen }\end{array}$ & totaal (n) \\
\hline $\begin{array}{l}\text { Hartslag Limburg is inpasbaar } \\
\text { binnen de geldende } \\
\text { financieringsregels. } \\
\text { De belangrijkste financier } \\
\text { (gemeente, respectievelijk } \\
\text { zorgverzekeraar) denkt mee. } \\
\text { De belangrijkste financier } \\
\text { (gemeente, respectievelijk } \\
\text { zorgverzekeraar) interpre- } \\
\text { teert de geldende finan- } \\
\text { cieringsregels ruimhartig. }\end{array}$ & 21 & 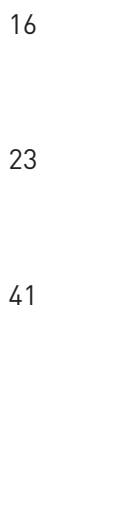 & 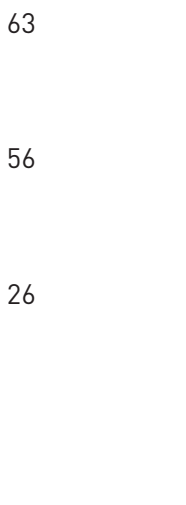 & $\begin{array}{l}100 \quad(62) \\
100 \quad(77) \\
100 \quad(74)\end{array}$ \\
\hline \multirow[t]{2}{*}{$\begin{array}{l}\text { Overheidsbeleid } \\
\text { Item uit vragenlijst }\end{array}$} & 2004 & & & \\
\hline & $\begin{array}{l}\text { 'geheel oneens' } \\
\text { en 'tamelijk } \\
\text { oneens' samen }\end{array}$ & neutraal & $\begin{array}{l}\text { 'geheel eens' } \\
\text { en 'tamelijk } \\
\text { eens' samen }\end{array}$ & totaal $(n)$ \\
\hline $\begin{array}{l}\text { Hartslag Limburg is inpasbaar } \\
\text { binnen de geldende } \\
\text { financieringsregels. } \\
\text { De belangrijkste financier } \\
\text { (gemeente, respectievelijk } \\
\text { zorgverzekeraar) denkt mee. } \\
\text { De belangrijkste financier } \\
\text { (gemeente, respectievelijk } \\
\text { zorgverzekeraar) interpre- } \\
\text { teert de geldende finan- } \\
\text { cieringsregels ruimhartig. }\end{array}$ & 24 & 22 & 16 & $\begin{array}{l}100 \quad(50) \\
100 \quad(50)\end{array}$ \\
\hline
\end{tabular}

Tabel 5.3 Factor Opstelling financiers: percentages van totaal. 


\section{Hoofdstuk 6 Lokale context}

\subsection{Inleiding}

In dit hoofdstuk volgt een nadere analyse van de factoren en subfactoren die gedefinieerd zijn binnen de dimensie 'lokale context'. D e dimensie lokale context bestaat uit drie factoren: 'bestaande samenwerkingsrelaties', 'kenmerken van bedrijfsvoering' en 'belangenstrijd actoren'. H ieronder wordt ter introductie eerst een overzicht gepresenteerd op basis van de feitenbeschrijving, het eerste deel van de tijdreeksanalyse. D aarna volgen, in de paragrafen $6.2 \mathrm{t} / \mathrm{m} 6.4$, per factor de complete resultaten van de tijdreeksanalyse. In paragraaf 6.2 worden resultaten uit de drie bronnen van de tijdreeksanalyse (feitenbeschrijving, interviews, enquêtes) na el kaar gepresenteerd. In de paragrafen 6.3 en 6.4 wordt daarentegen in subparagrafen ingegaan op specifieke thema's binnen de betreffende factor; ter wille van de leesbaarheid worden daar de resultaten meteen gëntegreerd gepresenteerd, in plaats van volgorderlijk per bron. Paragraaf 6.5 sluit af met een conclusie.

$0 p$ basis van de feitenbeschrijving is in figuur 6.1 het totaal aantal gebeurtenissen binnen de dimensie lokale context weergegeven. In de figuren $6.2,6.3$ en 6.4 is dit opgesplitst naar de drie factoren. Zoals toegelicht in paragraaf 3.4.3 komen de totaal scores van de figuren $6.2 \mathrm{t} / \mathrm{m} 6.4$ bij elkaar opgeteld iets hoger uit dan de totaalscore van 6.1; dit omdat gebeurtenissen soms in twee categorieën zijn meegeteld (bijvoorbeeld zowel onder kenmerk van bedrijfsvoering als belangenstrijd actoren).

Aan deze figuren valt op dat het merendeel van de gebeurtenissen beoordeeld is als belemmerend. $D$ at heeft deels te maken met de definities van de factoren: de indicatoren die scoren voor deze factoren, zoals 'krappe huisvesting', 'financiële tekorten', zijn bijna altijd belemmerend wanneer zij zich voor doen (zie paragraaf 3.2 en 3.5). 0 ok de onderlinge relatie tussen factoren draagt bij aan een cumulatief effect. Financiële tekorten maken bijvoorbeeld de kans op een belangenstrijd met nadelige gevolgen voor samenwerkingsrelaties groter. $\mathrm{N}$ iettemin maakt figuur 6.1 duidelijk dat in de voor de verankering meest cruciale jaren, 2003 en 2004, veel belemmerende gebeurtenissen in de lokale context zijn gesignaleerd.

U it de figuren is verder op te maken dat de factor 'belangenstrijd actoren' met 42 negatieve gebeurtenissen het hoogst scoort, met een piek in 2003 (figuur 6.4). D e factor 'kenmerken van bedrijfsvoering' scoort 21 negatieve gebeurtenissen (figuur 6.3), en 'bestaande samenwerkingsrelaties' scoort 8 negatieve gebeurtenissen. D e figuren geven een eerste indruk, de inhoudelijk inkleuring en trian- 
gulatie met de andere bronnen volgt in de betreffende paragrafen. Voor de leesbaarheid worden figuren 6.3 en 6.4 in de betreffende paragrafen herhaald.

\section{Lokale context}
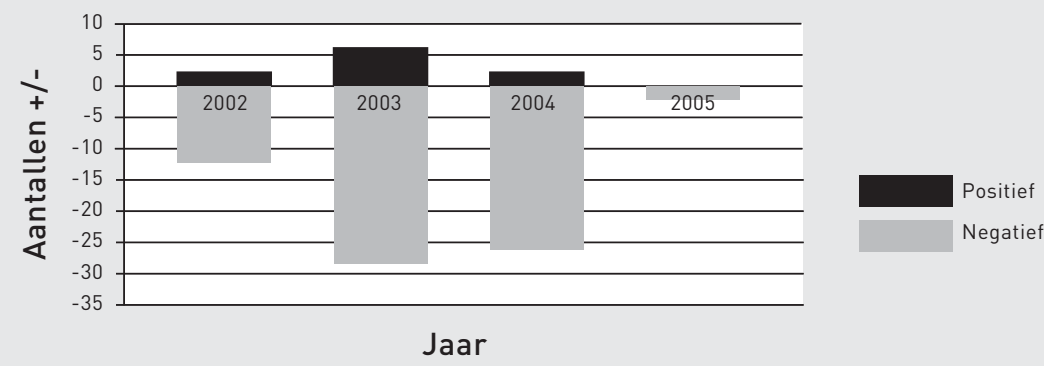

Figuur 6.1 Totaal aantal gebeurtenissen Lokale Context van de feitenbeschrijving

1a. Bestaande samenwerkingsrelaties
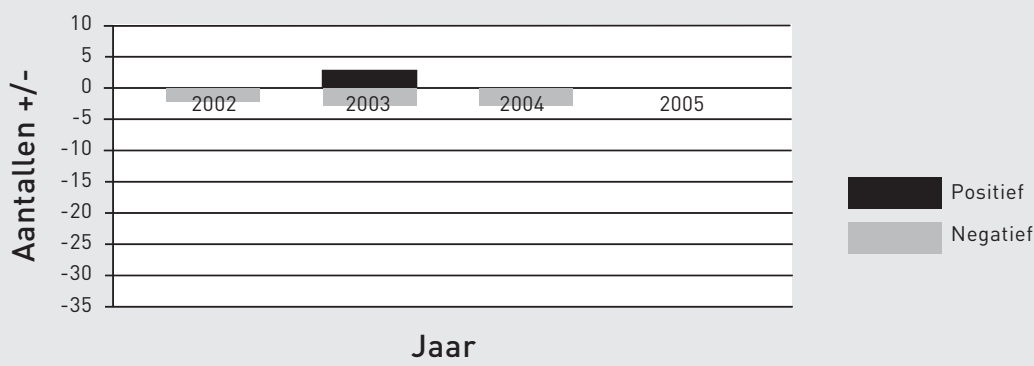

Figuur 6.2 Aantal gebeurtenissen van de factor Bestaande samenwerkingsrelaties

1b. Kenmerken van bedrijfsvoering

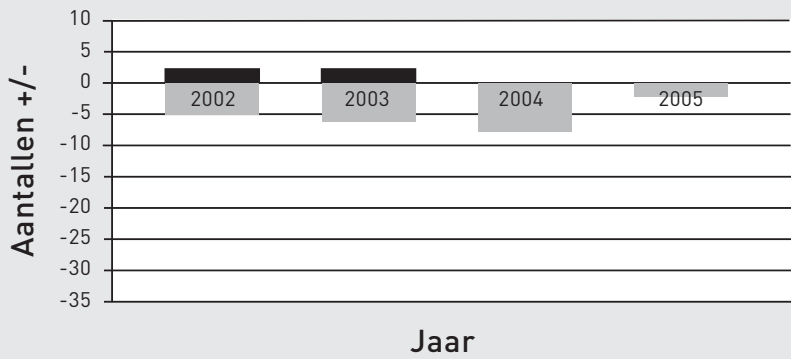

Positief Negatief

Figuur 6.3 Aantal gebeurtenissen van de factor Kenmerken van bedrijfsvoering 
1c. Belangenstrijd actoren
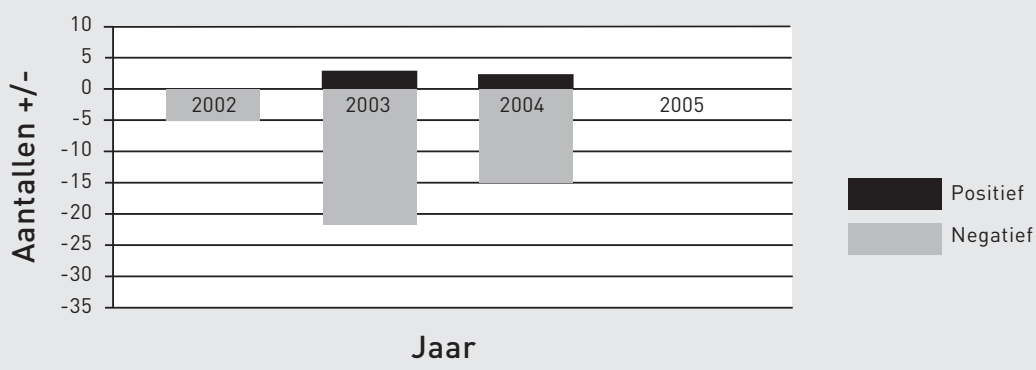

Figuur 6.4 Aantal gebeurtenissen van de factor Belangenstrijd actoren

\subsection{Bestaande samenwerkingsrelaties}

\subsubsection{Bestaande samenwerkingsrelaties: resultaten uit de feitenbeschrijving}

Figuur 6.2 laat zien dat op bestaande samenwerkingsrelaties niet bijzonder vaak gescoord is. D it is begrijpelijk omdat schriftelijke uitingen hiervan in documenten in onze bedrijfscultuur beperkt gehouden worden. Als meldingen plaats vinden dan zijn ze ook expliciet bedoeld. D e negatieve scores in deze tabel zijn dan ook te herleiden tot expliciete uitspraken en meldingen in notulen.

In 2002 betrof dit het spanningsveld tussen de directeur van de GGD en de voorzitter van het bestuur. D e directeur weigert nog langer via de ambtenaar volksgezondheid te moeten communiceren met deze voorzitter. De wethouder/ voorzitter houdt echter voet bij stuk (D 8). In dezelfde maand meldt de voorzitter "niet gecharmeerd te zijn van de nacalculering" die de GGD heeft toegepast op de afrekening van 2001. H et D B eist meer transparantie (D 10). Problemen in de onderlinge communicatie en de bedrijfsvoering lijken samen te gaan met spanningen tussen beide personen. O pvallend is daarbij de ingewikkelde constructie waarin de G GD -directeur enerzijds direct lijkt te moeten communiceren met zijn bestuursvoorzitter ten aanzien van regionale en bestuurlijke zaken en anderzijds indirect via de ambtenaar moet communiceren naar de wethouder als het individuele zaken van de betreffende gemeente aangaat. Een dergelijke constructie, die voortkomt uit de dubbelrol van de bestuursvoorzitter, moet wel een druk leggen op de onderlinge samenwerkingsrelatie. In paragraaf 6.4.6 wordt verder ingegaan op het aspect van de 'dubbele pet'.

H et vertrek van de GGD -directeur per mei 2003 en de komst van een interim 
(tijdelijk aangetrokken vanwege het in gang gezette fusietraject) lossen dit spanningsveld niet geheel op. 0 ok de Inspectie signaleert een stroeve relatie tussen GGD en gemeenten in haar beoordeling van de GGD eind 2003 (D 114). Begin 2004 signaleert de interim-directeur een trits van spanningsbronnen (zie 6.1.2); één daarvan is volgens hem dat er "te weinig wordt gënvesteerd in de kwaliteit van de onderlinge relaties" (D 139). D e negatieve score in figuur 6.2 in 2004 wordt verder veroorzaakt door het vertrek van de wethouder/bestuursvoorzitter begin juni uit de politiek (D 172). Achtergrond is een reeks conflicten met de betreffende gemeenteraad, waarbij in maart 2004 wethouder en raadscommissie elkaar verwijten zich niet te houden aan eerdere afspraken, met als gevolg dat de GGD -begroting wordt afgekeurd (D 147). Citaten uit dagblad De Limburger geven een beeld: "G oed overleg tussen raad en wethouder is belangrijk. En dat was niet goed." (D 172), uitspraak van de fractieleider van de partij van de wethouder). U it het hoofdredactionele commentaar: "W ie de functie van wethouder ambieert moet capaciteiten meebrengen. (..) W ie het niet kan moet weg. $\mathrm{H}$ ard, maar fair." (D 172)

Tot slot: soms kan een detail van doorslaggevend belang lijken, en het toch niet zijn. 0 p 17 april 2003 gaat de ambtenaar volksgezondheid van de gemeente $M$ aastricht, de belangrijkste inhoudsdeskundige en aanspreekpunt voor de GGD , op zwangerschapsverlof. Juist in de maanden hierna worden binnen de gemeente $M$ aastricht cruciale bezuinigingsvoorstellen opgesteld. Echter, of de aanwezigheid van deze ambtenaar een verschil had gemaakt valt uit de verzamelde data zeker te betwijfelen. D eze ambtenaar, en haar collega van Valkenburg, hebben namelijk zelf begin 2004 aangegeven weinig grip te hebben op bezuinigingsprocessen (D 127).

D e positieve scores in figuur 6.2 vertegenwoordigen de uitspraken van de gemeenten in de eerste helft van 2003 dat zij de GGD willen ontzien bij de gemeentebrede bezuinigingen. Verder is meegeteld dat samenwerkingsplannen tussen UM , azM en GGD tijdens een presentatie op 20 maart 2003 door de be stuursvoorzitter van het azM , positief worden ontvangen door de gemeentelijke bestuurders (D 49). D e presentatie onderstreept de nauwe samenwerking die GGD met UM en azM nastreeft, en het feit dat de bestuursvoorzitter van het azM persoonlijk de presentatie houdt zegt waarschijnlijk iets over de goede samenwerkingsrelaties tussen GGD en azM . Echter voor de gemeenten ligt hier niet hun eerste prioriteit. $\mathrm{Zij}$ geven aan vooral problemen te hebben met hun eigen begrotingen, de GGD moet geen extra geld voor deze mooie ambities verwachten (D 48).

$U$ it de scores op bestaande samenwerkingsrelaties komt met name een spanningsveld naar voren tussen de GGD -directeur en één of meerdere van de vijf portefeuillehouders, waaronder in elk geval de voorzitter. Voor een goed begrip moet dit gegeven geplaatst worden in een iets bredere context. Van de vijf por- 
tefeuillehouders die vanaf 1994 direct of indirect betrokken waren bij de opzet en ontplooiing van $\mathrm{H}$ artslag Limburg waren er in 2002 nog maar twee in functie; juist de drie meest direct betrokkenen waren vertrokken, waaronder de burgemeester die tevens bestuurslid was bij de $\mathrm{N}$ ederlandse $\mathrm{H}$ artstichting, en de voorzitter van het GGD -bestuur. D e gemeenteraadverkiezingen van maart 2002 leverde twee nieuwe portefeuillehouders op, waaronder de voorzitter. Anders gezegd: de persoonlijke samenwerkingsrelaties tussen G GD en gemeenten moesten voor een belangrijk deel vanaf medio 2002 opnieuw opgebouwd worden. Wat daarnaast een rol gespeeld kan hebben is dat sommige portefeuillehouders voor het eerst tegenover een veel kritischer gemeenteraad kwamen te staan, vanwege de introductie van het duale stelsel (zie 6.3.3). 0 pvallend is in elk geval dat voor het eerst in lange tijd twee van de vijf portefeuillehouders voortijdig hun functie moesten neerleggen.

\subsubsection{Bestaande samenwerkingsrelaties: resultaten uit de interviews en enquêtes}

$0 p$ het eerste gezicht worden de signalen over gespannen samenwerkingsrelaties tussen GGD en gemeente(n) uit het eerste deel van de tijdreeksanalyse niet meteen bevestigd door het tweede en derde deel.

U it interviews komt in het algemeen ten aanzien van de kwaliteit van de samenwerkingsrelaties naar voren dat respondenten spreken van open en functionele relaties. Wellicht heeft dit tevens te maken met de interpretatie van de vraagstelling. Immers, een functionele relatie hoeft enige spanning niet uit te sluiten en mogelijk is in interviews deels sprake van sociaal wenselijke antwoorden. D rie van de vijf portefeuillehouders blijken op andere momenten in het interview het bestaan van onderlinge spanningen weldegelijk te bevestigen. Zij koppelen die spanning echter eerder aan de omstandigheden dan aan de persoonlijke verhoudingen; in 2004 speelt dit nadrukkelijker nog dan in 2003.

$>$ "Nou, ik heb wat dat betreft positieve ervaringen met de GGD, zeker. Er is altijd op basis van openheid gewerkt aan het project, het enthousiasme was er, ook denk ik wederzijds. Maar je hebt als verantwoordelijk wethouder ook met andere partijen te maken, en daar ligt het moeilijke. "(55;14.08.2003)

"Nou er is toch wel wat spanning op het geheel gekomen. Enerzijds omdat binnen de GGD bezuinigd moest worden en anderzijds omdat gemeenten te maken kregen met forse bezuinigingen en men neigt er in de meeste gevallen toch toe om toch Hartslag Limburg als eerste onderuit te halen, vanwege het feit dat het als project gestart is. " $(55 ; 28.07 .2004)$ 
“Sterker nog, ik heb ook wel eens bij de GGD gezegd, anders dan de voorzitter van het $D B$, dat ik nog altijd blij ben dat ik me door de visie van een GGD laat bevruchten. Daar zitten ook de professionals, ik vind het ook helemaal niet erg dat ik mij laat inspireren door nieuwe ideeën. Alleen is het wel zo dat wij als gemeente veel meer de regierol moeten nemen, dat we echt moeten zeggen: tot zover. We moeten ook echt de grenzen gaan aangeven en de openbare gezondheidszorg die ruimte geven waarvan wij denken dat nodig is." (81;17.09.2003) "Er zijn communicatief, zowel op ambtelijk als op bestuurlijk niveau zijn er steken laten vallen, dat is niet goed gegaan, daar hebben we veel last van gehad. Ik ben in ieder geval blij met de nieuwe directeur, en dat we daar in zijn gaan doorpakken. Ik geef ook helemaal geen smet op de oude directie, die heeft ons lang genoeg gewaarschuwd: gemeenten, wat jullie allemaal willen, daar moet je veel meer geld voor betalen." (81; 15.07.2004)

Behalve de bezuinigingen wordt ook gewezen op een structureel element: de gemeenschappelijke regeling, impliciet eigenlijk de belangenconflicten die daarin spelen (o.a. dubbele petten problematiek (zie 6.4))

$>$ "Bestuurlijk is er een heel groot verschil, de GGD heeft een gemeenschappelijke regeling en daar heb je dan een heel andere rol in. Ik heb dat zelf nog eens een keer omdat ik voorzitter ben van dat bestuur, dan heb je ook veel meer contacten met de directie van de organisatie, dat ligt in de contactuele zin heel anders. Dit geeft toch een ander accent in de relaties. Dit is niet specifiek voor Maastricht. Naar de toekomst gekeken, als je het hebt over wenselijkheid, dan zou ik het prettig vinden als bestuurder, kijkende naar de GGD, daar wat verder van af moet staan, want volgens mij heb je daar beiden last van. (43;27.08.2003)

$H$ et beeld van een functioneel spanningveld in de samenwerkingsrelaties wordt door data uit de enquêtes ondersteund. Van de respondenten beoordeelt 70 tot $90 \%$ de kwaliteit van de onderlinge samenwerkingsrelaties als 'neutraal' tot 'zeer goed' (zie tabel 6.1). Een opvallende uitzondering hierop betreft echter de relatie met de gemeenten én de relatie met de zorgverzekeraar die in 2003 en 2004 door flinke percentages respondenten beoordeeld worden als 'slecht' tot 'zeer slecht'. Aangezien zowel gemeenten als zorgverzekeraar belangrijke financiers zijn spreekt hier wellicht vooral de functionele spanning in de samenwerkingsrelaties. Dit sluit in elk geval aan op antwoorden die elders in enquêtes worden gegeven over de rol van financiële knelpunten. G evraagd of de eigen organisatie 
kampt met financiële tekorten antwoordt in 2003 36\% van de respondenten bevestigend (tabel 6.2); van deze groep geeft $62 \%$ aan dat dit de samenwerking met $\mathrm{H}$ artslag Limburg 'belemmert' of 'enigszins belemmert'. In 2004 liggen beide percentages iets hoger; $46 \%$ van de respondenten geeft aan met tekorten te kampen en $74 \%$ acht dit (enigszins) belemmerend voor de samenwerking met $\mathrm{H}$ artslag Limburg.

\begin{tabular}{|c|c|c|c|c|c|c|}
\hline \multicolumn{7}{|c|}{ Bestaande samenwerkingsrelaties } \\
\hline \multirow{2}{*}{$\begin{array}{l}\text { Item uit vragenlijst } \\
\text { Hoe beoordeelt u de } \\
\text { samenwerking met: }\end{array}$} & \multicolumn{3}{|l|}{2003} & \multicolumn{3}{|l|}{2004} \\
\hline & $\begin{array}{l}\text { 'neutraal' } \\
\text { tot 'zeer } \\
\text { goed' }\end{array}$ & $\begin{array}{l}\text { 'slecht' } \\
\text { tot 'zeer } \\
\text { slecht' }\end{array}$ & $\begin{array}{l}\text { totaal } \\
\text { [n] }\end{array}$ & $\begin{array}{l}\text { 'neutraal' } \\
\text { tot 'zeer } \\
\text { goed' }\end{array}$ & $\begin{array}{l}\text { 'slecht' } \\
\text { tot 'zeer } \\
\text { slecht' }\end{array}$ & $\begin{array}{l}\text { totaal } \\
\text { (n) }\end{array}$ \\
\hline - de GGD & 92 & 8 & 100 (73) & 100 & 0 & $100(40)$ \\
\hline - de gemeente & 70 & 30 & $100(27)$ & 83 & 17 & $100(18)$ \\
\hline - het welzijnswerk & 88 & 12 & $100(60)$ & 93 & 7 & 100 (35) \\
\hline - de huisartsen & 88 & 12 & $100(41)$ & 96 & 4 & $100(23)$ \\
\hline - het azM & 86 & 14 & $100(57)$ & 93 & 7 & $100(31)$ \\
\hline - de UM & 92 & 8 & $100(62)$ & 97 & 3 & $100(36)$ \\
\hline - de zorgverzekeraar & 68 & 32 & $100(65)$ & 61 & 39 & $100(35$ \\
\hline
\end{tabular}

Tabel 6.1 Lokale context: factor Bestaande samenwerkingsrelaties (percentages van totaal).

\begin{tabular}{|l|l|l|l|l|}
\hline \multicolumn{2}{|l|}{$\begin{array}{l}\text { Bestaande samenwerkingsrelaties en Kenmerken van bedrijfsvoering } \\
\text { Item uit vragenlijst }\end{array}$ nee } & & ja & totaal (n) \\
\hline & 65 & & 36 & $100(76)$ \\
\hline $\begin{array}{l}\text { Mijn organisatie kampt met } \\
\text { financiële tekorten }\end{array}$ & 'bevorderend' & 'neutraal' & $\begin{array}{l}\text { 'lenigszins) } \\
\text { belemmerend' }\end{array}$ & $100(26)$ \\
\hline $\begin{array}{l}\text { Indien 'ja', in hoeverre werkt dit } \\
\text { bevorderend of belemmerend } \\
\text { op de samenwerking met } \\
\text { Hartslag Limburg? }\end{array}$ & 0 & 39 & 62 & \\
\hline
\end{tabular}




\begin{tabular}{|c|c|c|c|c|}
\hline \multicolumn{4}{|c|}{ Bestaande samenwerkingsrelaties en Kenmerken van bedrijfsvoering } & \\
\hline & nee & & ja & totaal $(n)$ \\
\hline \multirow{2}{*}{$\begin{array}{l}\text { Mijn organisatie kampt met } \\
\text { financiële tekorten }\end{array}$} & 54 & & 46 & $100(52)$ \\
\hline & 'bevorderend' & 'neutraal' & $\begin{array}{l}\text { '(enigszins) } \\
\text { belemmerend' }\end{array}$ & \\
\hline $\begin{array}{l}\text { Indien 'ja', in hoeverre werkt dit } \\
\text { bevorderend of belemmerend } \\
\text { op de samenwerking met } \\
\text { Hartslag Limburg? }\end{array}$ & 0 & 26 & 74 & 100 (23) \\
\hline
\end{tabular}

Tabel 6.2 Lokale context: invloed van factor Kenmerken van bedrijfsvoering op Bestaande samenwerkingsrelaties (percentages van het totaal).

\subsubsection{Bestaande samenwerkingsrelaties: conclusie}

Triangulatie van data uit de tijdreeksanalyse laat zien dat de factor 'bestaande sa menwerkingsrelaties' een rol heeft gespeeld in het moeizame klimaat rondom het verankeringsproces van $\mathrm{H}$ artslag Limburg tussen $\mathrm{GGD}$ en gemeenten. $\mathrm{N}$ a het aantreden van een nieuwe bestuursvoorzitter in 2002 blijkt communicatie tussen deze en de GGD -directeur niet optimaal. H oewel de direct betrokkenen daar zelf geen bevestiging van geven (c.q. niet meer bereikbaar waren voor interview), worden de spanning en tekortkoming in de communicatie door verschillende anderen, waaronder collega-bestuurders, wel gesignaleerd. Een mogelijke verklaring voor de gesignal eerde spanning ligt mede in de complexe manier waarop de directeur geacht wordt te communiceren met de bestuursvoorzitter die tevens wethouder is. Binnen het bestuur kan dit direct, maar daarbuiten gaat de communicatie richting wethouder via de ambtenaar volksgezondheid.

$H$ et feit dat de Inspectie het bestaan van een stroeve relatie tussen GGD en gemeenten signaleert in november 2003, zes maanden na het vertrek van de voormalige GGD -directeur geeft aan dat er meerdere onderlinge relaties onder druk hebben ge staan. Dit wordt ondersteund door data uit enquêtes. $H$ ier is naar alle waarschijnlijkheid sprake van samenhang met andere factoren die hebben bijgedragen aan de bewuste persoonlijke spanningen. Dit komt verder aan bod in de volgende paragrafen. 


\subsection{Kenmerken van bedrijfsvoering}

1b. Kenmerken van bedrijfsvoering

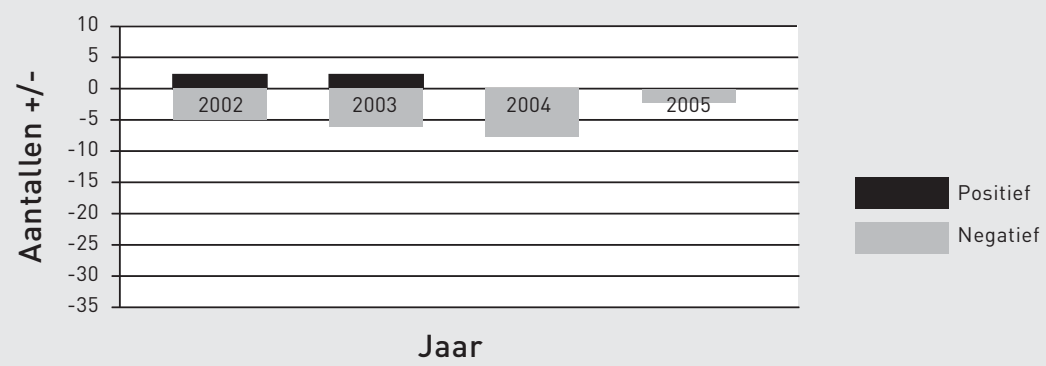

Figuur 6.3 Aantal gebeurtenissen van de factor Kenmerken van bedrijfsvoering

Wat betreft de factor 'kenmerken van bedrijfsvoering' overheersen in de feitenbeschrijving de negatieve scores (figuur 6.3). De belangrijkste gebeurtenissen betreffen hier kenmerken van bedrijfsvoering die direct of indirect te maken hebben met financiën. In het theoretisch model is hiervoor een aantal indicatoren benoemd (zie tabel 1, paragraaf 3.2). Analyse van de data uit de feitenbeschrijving heeft geleid tot een clustering rond de relevant gebleken indicatoren: 'fusie', 'financiële tekorten' en 'andere ontwikkelingen'. D aaruit is een viertal thema's naar voren gekomen: financiële transparantie, eindigheid van projecten, de fusie en het duale stelsel. D eze thema's worden in de volgende paragrafen uitgediept. Bij de triangulatie bleek dat gegevens uit de enquêtes hierbij slechts be perkt konden worden benut omdat de vraagstelling veelal te globaal was. Ter wille van de leesbaarheid worden de resultaten uit de drie bronnen van de tijdreeksanalyse geïntegreerd gepresenteerd.

\subsubsection{Kenmerken van bedrijfsvoering: financiële transparantie}

Als de gemeenten begin 2003 laten weten dat zij voor de GGD een uitzondering willen maken op de bezuinigingen heeft dat te maken met de bedrijfsvoering. De GGD is al vanaf 2001 van mening dat de indexering, d.w.z. de correctie voor inflatie en stijging van de gemiddelde leeftijd, te laag is. Bovendien is er onenigheid over de nieuwe tariefstructuur die nodig is voor de omschakeling van een inputbegroting naar productbegroting. G evolg is dat gemeenten in eerste instantie geen formele goedkeuring verlenen aan de begrotingen van 2002 en 2003, en dat deadlines worden overschreden. D e G GD lijkt aan de financiële tegemoetkoming niet genoeg te hebben: in de loop van 2003 worden vele 
varianten van het productenboek op ambtelijk niveau getorpedeerd omdat de nieuwe tariefstructuur telkens te hoog uitkomt. O orzaak ligt voor een deel aan het feit dat bij projecten, waaronder $\mathrm{H}$ artslag Limburg, geen overhead werd berekend. Voor veel projecten geldt verder dat de wachtgeldrisico's gedekt worden uit de algemene reserves. Anders zouden deze projecten niet meer mogelijk zijn, want er mogen van de gemeenten geen aparte 'risico-potjes' voor worden aangelegd (D 5, D 178). Volgens de interim-directeur heeft het lange traject van discussie over overheadberekeningen en dergelijke veel schade gedaan aan de relatie met de gemeenten. "Tegelijkertijd heeft die gebrekkige transparantie wel het beeld versterkt van een GGD die maar doet wat zij zelf goed dunkt." (D 139). Dat dit een serieus probleem is waar ook de interim onvoldoende raad mee weet blijkt in de maanden daarna. O p 15 maart 2004 keurt de raadscommissie van M aastricht de begroting voor 2004 af wegens onvoldoende transparantie. In juli blijkt de schade veel groter dan gedacht: de GGD worstelt door verschillende redenen met tekort van acht ton euro (D 178).

Specifiek bij $\mathrm{H}$ artslag Limburg kijken de gemeenten tegen twee systemen aan: de bijdrage vanuit het welzijnswerk staat in een outputbegroting, het GGD-deel in een inputbegroting.

$>$ "Het was in het begin heel onduidelijk wat nou de inbreng van alle partners was. Het heeft lang geduurd voordat dat steeds duidelijker werd. Ik denk dat Trajekt daarin vanaf het begin redelijk helder is geweest en dat heeft te maken met de wijze waarop wij onze systematiek van productfinanciering hebben. We kunnen tot in de komma laten zien wat we doen, waar we het doen, voor hoeveel mensen we het doen, wat het kost, we zijn al sinds 1999 bezig met die productfinanciering. De GGD is daar nu misschien twee jaar mee bezig." (126;04.09.2003)

Toch komt uit de triangulatie naar voren dat voor de gemeenten de kostenopbouw van $\mathrm{H}$ artslag Limburg niet onduidelijk was.

$>$ "Nee, dat weet ik dan zelf uit hoofde van mijn functie hoe dat gebeurd is, daar heb ik geen bedenkingen bij." (22;22.09.2003)

Veeleer lijkt er sprake van een andere visie. 
$>$ “lk denk dat je bij deze projecten ook vooral moet kijken naar de substitutie die plaatsvindt. Nou, al die partners doen op dat terrein al wat. Dan zeg ik, kijk nou eens naar wat als gevolg van dit project wat minder kan of kan wegvallen. En dat is wat er te weinig gebeurt. Het is niet zozeer een betere transparantie, want we zeggen er allemaal bij van hoe en wat we het doen. Maar waar het om gaat, dit is innovatie en dit zet je af tegen het bestaande beleid en dan blijkt dat binnen het bestaande beleid het innovatieve een deel overneemt. Er zit een dubbeling. Als het gaat om support, vanuit de plek waar je als bestuurder en gemeente zit, dat is dan vaak van 'oh, dus dat, en wat vervalt er nou?' (43;27.08.2003)

D e visie die hier verwoord wordt staat eigenlijk haaks op de basisvisie van $\mathrm{H}$ artslag Limburg (zie 2.4). Samenwerking tussen organisaties werd mede opgebouwd door bijdragen uit eigen middelen. Zo werden gelden voor sociale activiteiten gecombineerd met middelen voor voorlichting op buurtniveau. Wanneer deze combinaties vervolgens geoormerkt gaan worden als 'dubbeling', en dus rijp voor bezuiniging, vervalt de basis voor samenwerking. De samenwerking wordt immers bestraft. In paragrafen 6.4.4 en 8.3.3 komt aan de orde dat de hierboven geciteerde visie aan de basis lag voor de bezuiniging door de gemeente $M$ aastricht.

Terug naar bedrijfsvoering op organisatieniveau tussen GGD en gemeenten. In de nieuwe systematiek moeten overhead en wachtgel drisico's wel meegenomen worden, maar hierdoor ontstaat in 2003 het beeld dat de GGD , c.q. H artslag Limburg, steeds méér geld vraagt (D 101, D 108).

D e belangrijkste gevolgen van het gebrek aan financiële transparantie op organisatieniveau komen boven tafel medio 2004. O p 22 juli presenteert de directeur een somber beeld aan het voltallige G GD -personeel. D oor verschillende problemen worstelt de GGD met een tekort van acht ton euro. Redenen die genoemd worden zijn: "a) gemeentelijke bijdragen bleven op nullijn ondanks gestegen personele lasten, b) het wegvallen van extra (deels externe) projectfinanciering, en c) de risico's van markttaken (reisvaccinaties t.g.v. SARS en negatieve resultaten Buro Bedrijfshulpverlening) waarvoor bestuurlijk geen toestemming was om reserve op te bouwen" (D 178).

Zoals we in 6.3.3 zullen zien hangt het moment van uitkomen van deze informatie samen met de voorbereidingen voor een fusie: die dwingt tot meer transparantie. Tegelijkertijd betekent dit dat meerdere financiële problemen op hetzelfde moment boven tafel komen: een voor $\mathrm{H}$ artslag Limburg ongelukkige contextuele situatie. 
Geconcludeerd kan worden dat gebrek aan financiële transparantie niet op projectniveau maar wel op organisatieniveau een rol gespeeld heeft. $\mathrm{H}$ et begrotingsconflict in de jaren 2002 - 2004 tussen G GD en gemeenten droeg bij aan een negatief klimaat. In dit traject leek $\mathrm{H}$ artslag Limburg door de omschakeling van input- naar output begroting enige tijd een stuk duurder. M edio 2004 blijkt plots dat de tekorten van de GGD om verschillende redenen veel groter zijn dan gedacht. H et thema 'gebrek aan financiële transparantie' binnen de factor bedrijfsvoering draagt op dat moment sterk bij aan een negatief klimaat voor de verankering van $\mathrm{H}$ artslag Limburg.

\subsubsection{Kenmerken van bedrijfsvoering: 'projecten zijn eindig'}

H et belang van financiële transparantie hangt samen met de beheersbaarheid van projecten. D it punt spoort met twee andere negatieve scores in figuur 6.3 die beide betrekking hebben op het uitgangspunt dat projecten eindig moeten zijn. D e eerste gebeurtenis betreft de schriftelijke toelichting op het bezuinigingsvoorstel van de gemeente $M$ aastricht, waarin staat:

"D e voorgestel de maatregelen hebben geen ingrijpende gevolgen voor doelen: het project H artslag bij de GGD is G SB-impulsbeleid en is dus eindig." (D 78). $D$ e tweede gescoorde gebeurtenis betreft de uitspraak van een portefeuillehouder die aangeeft dat " $O$ mdat het in het verleden gold als 'project', met dus een tijdelijk financiel karakter, telt Hartslag Limburg voor 2004 voor de gemeente toch als en nieuwe begrotingspost" (D 101).

H et lijkt er op dat hier twee visies over de functie van 'projecten' botsen: de GGD wil via deels extern gefinancierde projecten gemeenten overtuigen om te komen tot structurele (extra) investeringen ten behoeve van een verbeterde gezondheidsbevordering. G emeenten daarentegen zien projecten veelal als een tijdelijke impuls waar zij geen nadere besluitvorming, beleidsmatig of financieel, voor hoeven in te plannen. Voor de GGD is een project een experiment dat bij succes gecontinueerd dient te worden (bij $\mathrm{H}$ artslag Limburg als uitgangspunt samen met gemeenten en $\mathrm{H}$ artstichting vastgelegd (zie Ruland et al., 1999a, paragraaf 2.4). Voor gemeenten is een project een activiteit met een begin en vooral een eind.

$>$ "Het enige probleem wat Hartslag Limburg op een gegeven moment boven zich kreeg, was dat het als een project begonnen is, en dat het niet als een project gefungeerd heeft, maar dat het als een basistakenpakket is gaan werken. En gemeenten hebben van tevoren gezegd: nee, een project is een project, en het 
moet een kop en een staart hebben. (...) We hadden ons met Hartslag Limburg van tevoren vele malen beter moeten realiseren: het is een kop en een staart verhaal." (81;15.07.2004)

H et is opvallend dat dit soort uitspraken gedaan worden door portefeuillehouders die niet betrokken waren bij de oorspronkelijke Stuurgroep van $\mathrm{H}$ artslag Limburg: wellicht is de kennisoverdracht van portefeuillehouder op portefeuillehouder, dan wel via ambtenaren en vanuit de GGD, op dit punt onvoldoende geweest. D it laatste is dan een leerpunt voor het verandermanagement: de oorspronkelijke uitgangspunten van een project dienen steeds op de bestuurlijke agenda gehouden te worden, zeker bij de komst van een nieuwe portefeuillehouder. Anderzijds blijkt uit triangulatie dat kritiek op het projectmatige karakter door bestuurders pas gemeld wordt wanneer er bezuinigd moet worden. De GGD heeft continuering van $\mathrm{H}$ artslag Limburg door de jaren heen steeds geagendeerd. Begin 2003, bij opname in de conceptnota's, bestaat er geen bezwaar (zie 8.3.2). H et is dus de vraag hoe zuiver deze kritiek was.

D e visie van de gemeenten op 'projecten' komt behalve in verslagen van bestuursvergaderingen ook naar voren in de interpretatie van regelgeving van het G rote Stedenbeleid. Waar H artslag Limburg in de periode 1997-2003 nog gefinancierd werd uit GSB-gelden met een expliciet kenmerk dit te continueren, blijkt in $2003 \mathrm{H}$ artslag ineens afgevoerd van de lijst 'te continueren projecten', en wordt plots een tegengesteld principe als argument gehanteerd. H ier lijkt eerder sprake van een belangenstrijd (zie 6.4.4).

D e eindigheid van projecten kan ook in een breder kader worden geplaatst. D it betreft de uitspraak van de interim-directeur van de GGD "dat het bestuur het overzicht over de veelheid aan G GD -projecten kwijt was" (D 139). D eze uitspraak spoort met een eerder signaal van gemeenten. Als eind 2002 de GGD opnieuw landelijke subsidie voor een groot project verwerft (SchoolSlag), spreken de gemeenten uit te vrezen voor toekomstige kosten bij continuering van dit project (D 29). H ierbij wordt verwezen naar de situatie van $\mathrm{H}$ artslag in de periode 2000/2001 (zie hfdst. 2.5.4), waarvan enkele portefeuillehouders vinden dat zij destijds tegen hun zin akkoord zijn gegaan met verlenging van de financiering.

$\mathrm{H}$ ier komt een algemener organisatorisch probleem boven tafel, dat te maken heeft met zowel bedrijfsvoering, als met een belangenstrijd tussen actoren, en ook met leiderschap. Namelijk, hoe kan het ondernemerschap dat in een GGD opbloeit, tot een veelheid aan projecten leidt en een groeiende claim legt op algemene middelen in goede banen worden geleid. $H$ et belang van professionals 
die betere kwaliteit nastreven botst met dat van bestuurders die de financiën moeten bewaken. Leiderschap vanuit de directie van de GGD is vereist om die belangen in balans te houden. $G$ een gemakkelijke taak, maar het volgende citaat duidt er op dat de directie van de GGD mogelijk kansen heeft laten liggen.

$>$ "En daar speelde ook nog het probleempje dat de financiering van Hartslag Limburg in de begroting van de gemeente ook heel nadrukkelijk als een projectfinanciering stond. I had een bedrag structureel WCPV en daarnaast een projectfinanciering Hartslag Limburg; (...). In zijn directe relatie, ook gezien de grote van de bedragen, is Hartslag Limburg eigenlijk dubbel gepakt." (81;15.07.2004) (zie ook 5.3.2)

Samenvattend kan geconcludeerd worden dat een belangrijk uitgangspunt van $\mathrm{H}$ artslag Limburg, de continuering bij succes, botste met het thema 'eindigheid van projecten'. Dit thema speelde een rol zowel in de visie van enkele portefeuillehouders, als in regelgeving binnen het GSB, als door de ambitie van de GGD om tegelijkertijd meerdere grote projecten te realiseren.

In een eerdere fase van $\mathrm{H}$ artslag Limburg (periode 2000-2001) werden de eerste twee van deze drempels overwonnen (zie 2.5.4). In de periode 2003-2004 stak het thema eindigheid van projecten echter opnieuw de kop op en droeg bij aan een negatief klimaat voor verankering.

\subsubsection{Kenmerken van bedrijfsvoering: fusie en het duale stelsel}

Vanaf medio 2002 krijgt het idee van een fusie tussen de drie Zuid-Limburgse GGD 'en steeds concreter vorm. Begin 2003 is een bestuurlijk visiedocument opgesteld en medio 2003 krijgt de interim-directeur van de GGD expliciet de opdracht prioriteit te geven aan het realiseren van de fusie. In februari 2004 gaan werkgroepen op professioneel en management niveau aan de slag om te komen tot voorstellen voor geïntegreerde werkwijzen.

O 2 oktober2003, als plots duidelijk is geworden dat de gemeente $M$ aastricht $€ 91.000$ bezuinigt op $\mathrm{H}$ artslag Limburg via de begroting van het welzijnswerk, verwerpt de GGD -directeur het advies van de projectleider om gezamenlijk met het welzijnswerk actie te ondernemen tegen dit besluit. Als reden hiervoor wordt 0.a. de fusie genoemd (D 97).

0 p 21 juni 2004 bespreekt het D B de resultaten van het eerste kwartaal. De directeur GGD geeft aan dat het hem en het M T ontbreekt aan voldoende sturingsmiddelen om aan de opgelegde taakstellingen te voldoen en de begrotings- 
tekorten op te lossen. D e GGD staat onder druk haar tekorten versneld op te lossen omdat "een toezegging gedaan zal moeten worden aan de fusiepartners dat de GGD haar eigen problemen zal oplossen" (D 173). De directeur stelt voor een overbruggingsplan te maken tot aan de fusiedatum, met een extra beroep op de gemeenten voor een "overgangsbijdrage". D e bestuurders reageren negatief op dit voorstel: "Verwacht wordt dat de gemeenten er waarschijnlijk niet aan willen een saneringsbijdrage te leveren aan de GGD op de drempel van de fusie. $O$ verigens merkt één van de portefeuillehouders op dat de vorige directeur het bestuur een aantal malen heeft gewaarschuwd."( D 173).

O p 1 juli 2004 bespreekt het AB uitgebreid de stand van zaken rond de begroting 2005 en de fusie. M en verwacht "zwaar weer op komst, wat ongunstig is voor de positie van de GGD binnen het fusieproject" en "het traject 'aanhalen van de broekriem' is begonnen". "D oor de extra belasting van de fusie zal er wellicht op inhoudelijke taken ingeboet moeten worden", want per saldo willen de gemeente slechts minimaal aanvullend subsidiëren. $0 p$ de vraag van meerdere van de aanwezigen "hoe het dan zo ver heeft kunnen komen" en "of de gemeenten wel voldoende betaald hebben" wordt door een collega bestuurder gezegd "dat de vorige directeur gesteld heeft dat de financiële opvattingen van gemeenten 'dodelijk' zijn voor de continuïteit van de GGD". Toegevoegd wordt "dat de GGD inhoudelijk een uitstekende reputatie heeft landelijk gezien, er is goed inhoudelijk werk verricht" (D 175).

D rie weken later, op 22 juli, wordt een somber beeld gepresenteerd aan het voltallige GGD -personeel. D oor verschillende problemen worstelt de GGD met een tekort van acht ton (zie 6.3.1). H et beleid wordt gericht op "gezond de fusie ingaan". "H et D B heeft de GG D opgedragen om terug te gaan naar de kerntaken en een traject van versobering in te zetten. $H$ et $D B$ heeft aangegeven dat hiermee de wettelijke eisen niet in gevaar mogen komen. $\mathrm{H}$ ieronder vallen deJGZ, GVO (...)." (D 178).

Enerzijds wordt ook in het fusietraject door gemeenten erkend dat $\mathrm{H}$ artslag Limburg binnen het verplichte taakdeel dient te vallen, maar het 'niet in gevaar komen' wordt over gelaten aan de GGD. Ten aanzien van de fusie stelt het $D B$ vast: "D e kosten hoopt men via inverdieneffecten te verhalen. $\mathrm{H}$ et is niet de bedoeling de lopende begrotingen van de fuserende partners te belasten. (..) H et budget van de nieuwe organisatie mag niet meer bedragen dan de som van de budgetten van de fuserende partners" (D 177). H et opgelegde versoberingstraject brengt het GGD management er toe om voor nog eens bijna een ton te bezuinigen op $\mathrm{H}$ artslag Limburg.

H ier komt naar voren dat het fusieproces aanleiding was voor grotere financiële transparantie en het op korte termijn saneren van tekorten en lopende financiële risico's. D eze lokale context heeft de speel ruimte voor verandermanagement 
vanuit de GGD ongetwijfeld beperkt. Wat de GGD hier zelf aan gedaan heeft of had kunnen doen komt aan bod in hoofdstuk 8.3.4.

D at gemeentelijke bestuurders weinig geneigd zijn om de GGD bij de fusie financieel te helpen moet natuurlijk ook geplaatst worden in het licht van de bezuinigingen die $\mathrm{D}$ en $\mathrm{H}$ aag hen had opgelegd (zie 5.3). Verder dient nog één ander aspect vermeld te worden: het in 2002 in de gemeenteraad ingevoerde duale stelsel. Kern van de nieuwe verhoudingen betreft de scherpere scheiding tussen de uitvoerende rol van $B \& W$ en de controlerende rol van de gemeenteraad. In sommige gemeenteraden lijkt dit te leiden tot een veel kritischer optreden van raadsleden. Feit is dat medio 2004 twee van de vijf portefeuillehouders na flinke kritiek van hun raad, onvrijwillig zijn opgestapt; amper de helft van hun termijn volmakend. H oewel in de lokale pers kritiek op het professioneel functioneren van deze wethouders de boventoon voerde (zie 6.2.1), kan moeilijk uitgesloten worden dat het recent ingevoerde duale stelsel bijgedragen heeft aan een klimaat waarin misstappen harder worden afgestraft en bestuurders dus minder risico willen nemen.

Triangulatie met interviews laat vooral opmerkelijke verschillen zien in de uitspraken van gemeentelijke bestuurders over de invloed van de fusie.

$>$ "Laat ik zeggen: de fusies hebben op geen enkele wijze invloed gehad richting Hartslag Limburg" (81;15.07.2004)

“Ja, nu zijn er andere impulsen gekomen, maar niet meer zozeer vanuit Hartslag Limburg, nu is gewoon dat fusieproces bepalender dan Hartslag Limburg, dat weegt zwaarder. (57;19.10.2004)

Geconcludeerd kan worden dat het fusietraject, in combinatie met het daardoor boven tafel komen van serieuze tekorten op meerdere bedrijfsonderdelen, in belangrijke mate bijgedragen heeft aan een klimaat waarin nauwelijks nog ruimte is voor een innovatiebudget. $H$ et gemeentelijke uitgangspunt van een financieel neutraal verlopende fusie weegt zwaarder dan het streven naar verankering van $\mathrm{H}$ artslag Limburg. $\mathrm{D}$ aarnaast is het mogelijk dat de introductie van het duale stelsel bestuurders nog voorzichtiger heeft gemaakt. In elk geval is aannemelijk dat het thema fusie, en in mindere mate het duale stelsel, bijgedragen hebben aan een negatief klimaat voor verankering. 


\subsubsection{Kenmerken van bedrijfsvoering: conclusie}

In paragraaf 6.3 is de factor bedrijfsvoering van de dimensie lokale context uitgediept op een viertal thema's die de relatie GGD - gemeenten betreft: financiële transparantie, de eindigheid van projecten, en het fusietraject tussen de drie ZuidLimburgse GGD 'en en het duale stelsel. D e toegepaste triangulatie heeft het beeld uit de feitenbeschrijving vooral ten aanzien van de eerste drie factoren bevestigd en in zijn onderlinge samenhang aangescherpt. Er was een langslepend traject waarin de GGD moest omschakelen van input- naar outputbegroting, kritiek op de GGD vanwege gebrek aan financiële transparantie, beschuldigingen van de GGD directeur richting gemeenten over een jarenlange onredelijke financiële koers door ge meenten, en verschil in visie op de eindigheid van projecten samenhangend met een eenzijdig door de gemeente $M$ aastricht herziene interpretatie van GSB-regelgeving. Verder kwamen in 2004 forse tekorten op meerdere bedrijfsonderdelen boven tafel, op een moment dat bestuurders besloten dat de fusie voor de gemeenten niks extra mocht kosten. Geconcludeerd moet worden dat deze kenmerken van bedrijfsvoering een aanmerkelijk beperkende invloed uitgeoefend hebben op het klimaat rond de verankering van $\mathrm{H}$ artslag Limburg. D e toegenomen financiële druk vormde een centraal element in het proces waarin de GGD uiteindelijk werd opgezadeld met een schier onmogelijke opdracht: strikt bezuinigen en tegelijkertijd de 'wettelijke eisen', inclusief H artslag Limburg, overeind houden. D e volgende paragraaf be kijkt het verankeringsproces vanuit de tegenstrijdigheid aan belangen die in de lokale context speelden.

\subsection{Belangenstrijd actoren}

\subsubsection{Belangenstrijd actoren: inleiding}

1c. Belangenstrijd actoren
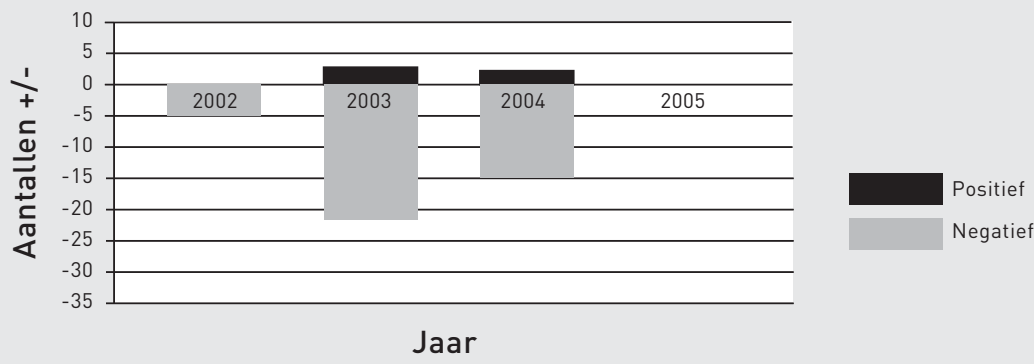

Figuur 6.4 Aantal gebeurtenissen van de factor Belangenstrijd actoren 
In deze paragraaf wordt de factor Belangenstrijd actoren nader geanalyseerd. D e analyse is gebaseerd op feitenbeschrijving en interviews. Bij de triangulatie kon geen gebruik gemaakt worden van data uit de enquêtes omdat deze factor pas toegevoegd is aan het model nà afname van de enquêtes (zie 3.4.5).

In figuur 6.4 zijn de resultaten van de feitenbeschrijving weergegeven van de factor 'belangenstrijd actoren', de derde factor binnen de dimensie lokale context. Wat opvalt zijn de hoge negatieve scores in 2003 en 2004. Blijkbaar valt in een groot aantal gebeurtenissen een belangenstrijd te herkennen. Alle negatieve scores blijken bovendien betrekking te hebben op de actoren van GGD en gemeenten. D e positieve scores in de figuur betreffen een klein aantal gebeurtenissen waar actoren een potentiële belangenstrijd wisten om te buigen in een positieve gebeurtenis (samenwerking van G GD , azM , U M en gemeenten rondom het beoogde ' $O$ ntwikkelcentrum $O$ penbare G ezondheidszorg', en samenwerking gemeenten - GGD in het kader van het fusietraject en het convenant met het N IGZ).

O $\mathrm{m}$ inzicht te krijgen in de aard van de belangenstrijd zijn de negatief gelabelde gebeurtenissen gegroepeerd naar een aantal thema's. 0 p deze manier zijn vijf thema's van belangenstrijd geïdentificeerd:

1. De (interne) concurrentie tussen $\mathrm{H}$ artslag Limburg en andere beleidsprioriteiten van de GGD.

2. $\mathrm{H}$ et belang om te investeren in gezondheidsbevordering versus het belang van kostenbeheersing.

3. Complexiteit accepteren vanwege bijdragen door andere sectoren (welzijnswerk) aan gezondheid versus het handhaven van een simpele organisati estructuur (scheiding van 'welzijn' en 'gezondheid').

4. Lokale (gemeentelijke) belangen versus regi onale (intergemeentelijke) belangen.

5. D e dubbele petten problematiek: bestuurders die zowel het GGD -belang als het gemeentelijke belang moeten behartigen komen in de knel: als bestuurder van de GGD kan iemand vóór een bepaald initiatief zijn, terwijl hij vanuit de gemeentelijke bestuursrol tegen moet zijn.

D e gemeenschappelijke noemer van deze thema's is: geld. D e middelen zijn schaars, en in deze casus zelfs krimpend, en dus worden op allerlei niveaus belangen tegen elkaar afgewogen om de benodigde keuzes te kunnen legitimeren.

\subsubsection{Belangenstrijd actoren: concurrentie om beleidsprioriteit}

Een van eerste drempels waar GGD medewerkers begin 2003 tegenop lopen, is het realiseren van een duurzaam plaats van $\mathrm{H}$ artslag Limburg in het in opbouw 
zijnde Productenboek van de GGD . In dit productenboek zijn als eerste de reguliere activiteiten uit de GGD -begroting opgenomen. $\mathrm{N}$ ieuwe activiteiten worden als apart inkoopbare 'plusproducten' opgenomen. D it laatste maakt een product rijp voor bezuiniging, getuige deze uitspraak van een portefeuillehouder.

$>$ "Als je het als lokaal en apart inkoop product moet zien, dan weet u met mij dat dan op dat moment de vergelijking gemaakt gaat worden met het achterstallig onderhoud van wegen. En dat is het voor mij eigenlijk niet waard, het zou eigenlijk zo moeten verdisconteerd zijn dat ik die discussie niet hoef te voeren." (81;17.09.2003)

O ok binnen de GGD is er weerstand te overwinnen: traditioneel 'erkende' producten als epidemiologie en publieksvoorlichting wensen geen concurrentie van het product $\mathrm{H}$ artslag binnen de categorie 'basis'. (D 43;D 141)

Bij enkele bestuurders leidt dit beeld medio 2003 tot weerstand. D e verwoording van deze weerstand in het D B leidt tot actie van de GGD (gesprek op 13.10.2003; zie 4.3.3 en 8.2.5).

$>$ "Wat mij stoort is dat men eigenlijk heel veel licht richt op Hartslag Limburg, alsof dat de alleszaligmakende activiteit is, terwijl er heel veel meer is waar de gemeente, in het kader van die wetgeving, mee bezig moet zijn. Nou, Schoolslag is daarbij eigenlijk aangeschoven hè, Breedte-sport-impuls is daarbij aangeschoven en wat mij een beetje bezorgd maakt is dat we straks een beetje een onbeheersbaar brede activiteit hebben waar we geen geld voor hebben, want dat is nu toch een beetje aan de orde.(22;22.09.2003)

In de feitenbeschrijving komen meerdere signalen langs die te interpreteren zijn als concurrentie om beleidsprioriteit binnen het inhoudelijke domein van de publieke gezondheid. Ambtenaren noemen 0.a. het Schoolslag-project, het AED -project (het installeren in wijken van reanimatieapparaten), de samenwerking met azM en $U M$ in een nieuw op te richten centrum ( $O$ ntwikkelcentrum 0 penbare G ezondheid) en de daarmee samenhangende plannen voor nieuwbouw. De Inspectie vult dit aan met haar waarschuwing dat "markttaken afleiden van de hoofdtaak" (D 114), D eze brief krijgt extra gewicht door de verklaring van juli 2004 van het GGD -bestuur dat de forse tekorten van de GGD mede aan deze markttaken te wijten zijn (D 178), 
In hoofdstuk 8.3.4 komt aan de orde hoe binnen de GGD in 2004 bij stijgende tekorten uiteindelijk het cluster gezondheidsbevordering de laagste prioriteit krijgt.

\subsubsection{Belangenstrijd actoren: investeren of bezuinigen}

Een hele reeks scores op de factor belangenstrijd in de feitenbeschrijving is te herleiden tot het spanningsveld tussen 'de wens om te innoveren' enerzijds en 'de noodzaak tot bezuinigen' anderzijds. H et eerste is vooral een belang van de $G G D$, het tweede van de gemeenten. Die tegenstelling komt mede voort uit het feit dat gemeenten jarenlang weinig inhoudelijke belangstelling hadden voor de publieke gezondheidszorg. Pas sinds de verplichting een nota te maken is er meer aandacht gekomen.

$>$ Nou, in zijn algemeenheid, dat is gewoon bekend, de publieke gezondheidszorg, waar de GGD onder valt, kan niet rekenen op een brede belangstelling, en ook niet op een breed inzicht over wat zij doet, noch bij de bevolking, noch bij de gemeenteraadsleden. (..)En op een gegeven moment was het idee gegroeid van: dat zal wel nodig zijn. (..) Maar vervolgens had men dan ook het idee: nou, dat dóen ze bij de GGD goed, dat is in goede handen, wij maken het geld over, en laten hen hun werk ongestoord doen. En verder bemoeide niemand zich ermee, tot en met de portefeuillehouder. Maar nu begint dat, nu wel, het heeft wat meer aandacht gekregen, integratie enzovoorts. Hartslag Limburg is ermee naar buiten gekomen, en de GGD zelf. (..) Maar tot een jaar of twee geleden leefde dat helemaal niet. (57.19.10.2004)

In de geturfde gebeurtenissen vallen er een aantal op. In juli 2003, kort na accordering van de $\mathrm{M}$ aastrichtse nota waarin $\mathrm{H}$ artslag Limburg is opgenomen, zegt de bestuursvoorzitter toe de besluitvorming over continuering van $\mathrm{H}$ artslag Limburg te koppelen aan de resultaten van de evaluatiestudies (D 82). D eze toe zegging wordt niet nagekomen. Al op 29 september 2003 wordt namens deze portefeuillehouder een cruciaal bezuinigingsvoorstel ter grootte van € 91.000 in de raadscommissie van de gemeente $M$ aastricht aangenomen (D 95, D 97). $\mathrm{H}$ artslag Limburg wordt, zonder overleg met GGD en in tegenstelling tot eerdere verlenging, geschrapt van de lijst 'doorlopende GSB-projecten' waardoor financiering van de samenwerking met het welzijnswerk wegvalt. In dezelfde periode concluderen gemeenten dat projecten buiten de reguliere GGD -begroting vallen en dus ook buiten de toezegging om niet op het GGD -budget te bezuinigen. In een interview zegt de betrokken bestuurder: 
$>$ "Het mooiste voorbeeld is nu, in tijden van recessie of als het economisch wat minder gaat, dan moet je kijken waar er bezuinigd gaat worden en daar wordt niet gekeken naar effecten of wat dan ook, dat is gewoon heel plat, zo van waar kan ik dat weghalen?' Zonder dat je dan teveel oppositie creëert bij de mensen waar het dan om gaat." (43;27.08.2003)

Geconfronteerd met deze gang van zaken spreekt de directeur van het welzijnswerk zich uit: " $D$ it is onbehoorlijk bestuur als het gaat om het vaststellen van gemeentelijk gezondheidsbeleid en enkele maanden later weghalen van de benodigde financiën. Behalve bestuurlijk vind ik bedist dat dit traject ook ambtelijk niet goed is voorbereid". D e aanwezige ambtenaren geven aan "geen grip te hebben op de bezuinigingsprocessen; die bezuiniging van 91 mille had eigenlijk niet gemogen" (D 127). $\mathrm{H}$ et conflict tussen investeren of bezuinigen blijft de hele onderzoeksperiode aanwezig. Pogingen van de directeur om $\mathrm{H}$ artslag elementen een prominentere rol in het Productenboek te geven zouden zijn stukgelopen op de houding van ambtenaar en wethouder $M$ aastricht. $O$ nduidelijk is waar het conflict precies om draait. Duidelijk is wel dat het opstellen van de begroting 2005 zeer moeizaam verloopt (D 151). Zoals in paragraaf 6.3 al aangeven is de bottum line: fusie en financiële zorgen zijn belangrijker dan $\mathrm{H}$ artslag Limburg. Wanneer het er op aankomt kiezen de gemeenten niet echt: de GGD moet bezuinigen en tegelijkertijd de "wettelijke eisen", inclusief H artslag Limburg, overeind houden. Zoals in paragraaf 6.3.1 al beschreven maken de gemeenten het de GGD niet makkelijker doordat de financiële spelregels het de GGD onmogelijk maken om voldoende reserves aan te leggen. De manoeuvreerruimte van de GGD is daarmee sterk beperkt.

Los van eventueel aanwezige reserves is het ook een vraag, of de tegenstelling 'bezuinigen of investeren' altijd een tegenstelling moet zijn. Als de maatschappelijke opgaven om nieuwe oplossingen vragen kan het wijzer zijn om ondanks bezuinigingsdruk toch ook te investeren. O pvallend voorbeeld in hiervan is te vinden in de feitenbeschrijving van de samenwerking tussen GGD en azM . In deze databron zijn nauwelijks aanwijzingen voor concurrentie om beleidsprioriteit of het dilemma 'investeren versus bezuinigen' te vinden. En dat terwijl het ziekenhuis toch evenzeer fors moet bezuinigen. D e meest voor de hand liggende verklaring hiervoor is dat a) de samenwerking is opgenomen in de azM plannen voor vernieuwing, en $b$ ) de raad van bestuur van het azM er voor kiest om deze vernieuwing te vrijwaren van de noodzakelijke bezuinigingen (D 106).

H et beeld dat op dit thema boven komt is dat gemeenten anno 2003/2004 zich pas recent zijn gaan interesseren voor de inhoud van de publieke gezondheid. 
D aarvóór gold het primair als kostenpost. Een uitgewerkte visie op gedragsgerelateerde gezondheidsbevordering met een bijpassend (innovatie)budget ontbreekt in de lokale nota's. D e ruimte van de GGD om hierin zelfstandig beleid te ontwikkelen wordt bovendien beperkt door een gemeentelijk verbod op de aanleg van adequate reserves. In contrast hiermee heeft het azM wel een duidelijk inhoudelijke toekomstvisie, en reserveert daarvoor ook innovatiegeld.

\subsubsection{Belangenstrijd actoren: welzijn ò gezondheid}

Een derde thema in de belangenstrijd betreft de scheiding tussen 'welzijn' en 'gezondheid' in de gemeentelijke begrotingssystematiek. Bij de opbouw van $\mathrm{H}$ artslag Limburg is uitgegaan van het principe 'elke partner draagt bij uit eigen middelen' (paragraaf 2.4). D it principe werd mede gekozen om te bevorderen dat samenwerking daadwerkelijk zou aansluiten bij bestaande activiteiten van de partner. In de samenwerking tussen G GD en welzijnswerk resulteerde dit in een meerjaren afspraak dat de helft van de inzet van het welzijnswerk voor $\mathrm{H}$ artslag Limburg gefinancierd werd uit het reguliere welzijnsbudget voor wijkactiviteiten (paragraaf 2.5.2). Argument hiervoor was dat deze activiteiten zowel een gezondheidsbevorderend als een sociaal doel dienden. $\mathrm{N}$ a verloop van jaren kreeg deze post in de begroting van het welzijnswerk de titel 'bijdrage aan $\mathrm{H}$ artslag Limburg'. Bij de behandeling van het bezuinigingsvoorstel (€91.000 uit het GSBbudget) op 14 oktober 2003 in de raad van M aastricht luidt de argumentatie van de wethouder dat "dit gezondheidsbeleid betreft en dus thuishoort binnen de G GD -begroting". Verder wordt zelfs gesteld dat de GGD dit werk goedkoper zou kunnen doen, omdat het gezondheidsbevordering betreft (D 102). D e raad gaat uiteindelijk met deze argumentatie akkoord, en de portefeuillehouder vertaalt dit richting GGD als: de GGD moet deze taken overnemen, zonder de bijbehorende middelen. Hoe de GGD hier op reageert komt aan bod in paragraaf 8.3.4. Waar het hier om gaat is het botsen van twee visies, twee belangen. De argumentatie van de gemeente voor de bezuiniging is gericht op helderheid: middelen voor gezondheidsbevordering horen op de begroting van de GGD; als die daarvoor tevens welzijnswerk wil inschakelen, dan moet de GGD hen inhuren. $0 p$ zich is er niks mis met deze gedachte. Alleen, waar eerst samenwerking op basis van twee doelen (welzijn én gezondheid) gerealiseerd werd, wordt nu alles onder één doel, gezondheid, gelabeld. D an blijkt die inzet dus twee keer zo duur. Ergo: er kan zonder schade bezuinigd worden. D e portefeuillehouder verwoordt het helder: 
$>$ Ja, zoals ik er tegenaan kijk denk ik dat je bij deze projecten ook vooral moet kijken naar de substitutie die plaatsvindt. Ook in de immateriële zin. Hartslag Limburg als voorbeeld heeft een integrale denk- en werkwijze wat moet leiden tot de verbetering van zus en zo. Nou, al die partners doen op dat terrein al wat. Dan heb je het met elkaar mooi geformuleerd, en dan zeg ik, kijk nou eens naar wat als gevolg van dit project wat minder kan of kan wegvallen in de huidige manier omdat dit vervangt. En dat is wat te weinig gebeurt.(...) Er zit een dubbeling. Als het gaat om support, vanuit de plek waar je als bestuurder en gemeente zit, dat is dan vaak van 'oh, dus dat, en wat vervalt er nou?' (43;27.08.2003)

O pnieuw blijkt hier dat de gemeente kiest voor het substitutie-principe in plaats van het investeringsprincipe. D e gedachte dat effectieve gezondheidsbevordering het bundelen van welzijns- én GGD -activiteiten, en dus extra investeringen nodig heeft, wordt niet overgenomen.

\subsubsection{Belangenstrijd actoren: lokaal of regionaal}

Een vierde thema in de belangenstrijd tussen actoren binnen de lokale context betreft de verhouding tussen gemeenten onderling. De GGD werkt voor vijf gemeenten, maar die willen niet altijd hetzelfde. Een eerste voorbeeld uit de feitenbeschrijving betreft het niveau van verantwoording afleggen. Voor professionals van GGD en U M kan dit het beste op regionaal niveau, maar gemeenten willen elk apart de waarde van $\mathrm{H}$ artslag Limburg beoordelen voor de eigen gemeente. D e GGD komt hier aan tegemoet: de procesresultaten kunnen per gemeente gepresenteerd worden, voor de effectmaten is het gemeentelijk niveau echter te klein.

$\mathrm{H}$ et belangrijkste aspect van dit thema betreft echter ook hier de financiën. $M$ aastricht heeft in de gemeenschappelijke regeling tussen de gemeenten als grote stad een dominante rol. D it is logisch gezien de getal smatige verhoudingen (120.000 van de 185.000 inwoners) en wordt weerspiegeld in de bestuurlijke verhoudingen (in het $A B$ heeft elke gemeente drie leden, alleen de leden van $M$ aastricht hebben elk drie stemmen). Bezuinigingen door $M$ aastricht heeft naar de andere gemeenten toe al gauw een sneeuwbaleffect. Als de gemeente $M$ aastricht aangeeft "minder geld beschikbaar zal hebben voor de GGD als geheel", reageren de anderen onmiddellijk. "D e kleinere gemeenten vrezen dat zij de consequenties van het eenzijdige besluit van de gemeente $M$ aastricht zullen moeten dragen" (D 82). D it patroon herhaald zich nog twee keer. Als na M aastricht in december ook Valkenburg aangeeft op de GGD (en op H artslag Limburg) te wil- 
Ien bezuinigen, reageert een paar maanden later de gemeente Eijsden met een brief aan het $D B$ van de GGD. C itaat:

$>$ "Nu een aantal gemeenten te kennen heeft gegeven geen (Maastricht) of een veel geringere (Margraten en Valkenburg a/d/Geul) bijdrage te willen verlenen ten behoeve van Hartslag kan het niet zo zijn dat Meerssen en Eijsden hierin buitenproportioneel gaan bijdragen." (D148)

Als een maand later de gemeente $M$ argraten door verandermanagement van de GGD instemt met continuering en zelfs uitbreiding van $\mathrm{H}$ artslag Limburg, een raadsbesluit van 11 mei 2004, is die stap maar van korte duur. M argraten wil aan de GGD als geheel niet meer uitgeven dan proportioneel passend is. Eén van de bestuurders weet dit treffend te verwoorden:

$>$ "De relatie tussen gemeente en GGD is sterk afhankelijk van de grootte van de gemeente: kleine gemeenten hebben geen capaciteit, noch deskundigheid. Daarom willen we op de GGD vertrouwen, daar zitten de professionals. De grote gemeente Maastricht heeft dominante rol in de gemeenschappelijke regeling, dat botst wel eens. Het risico is dat daardoor de kleine gemeenten voor een 'fait accomplit' gezet worden. Daarnaast speelt de ontwikkeling van het

Productenboek: dit kan leiden tot verschillen tussen gemeenten in afname van producten, wat nadelig is voor gemeenten die wél iets willen afnemen. Dit is in mijn ogen nadrukkelijk strijdig met de gemeenschappelijke regeling."

(57; 13.08.2003)

D e resultante is opnieuw een mechanisme, te typeren als 'regressie naar het laagste gemiddelde': gemeenten die een product willen afnemen, komen op dit besluit terug als blijkt dat anderen gemeenten uit de regio dit niet doen. Dit werkt vooral voor producten die de gemeentegrens overstijgen: producten met een massamediale component en 'innovatie'. Zo draagt de belangenstrijd op regionaal niveau ertoe bij dat investeren in innovatie wordt belemmerd.

\subsubsection{Belangenstrijd actoren: de dubbele pet}

Tot slot een vijfde aspect van belangenstrijd tussen actoren: de dubbelfunctie van een portefeuillehouder (wethouder of burgemeester) die tegelijkertijd 
bestuurder is van de GGD . In paragraaf 6.2 (Bestaande samenwerkingsrelaties) kwam al aan bod dat dit aspect druk kan leggen op de relatie tussen bestuurder en directie. D esalniettemin: bij de meeste GG $\mathrm{D}$ 'en is deze constructie standaard. Als sterke kant van dit model wordt genoemd dat de GGD via haar bestuurders ambassadeurs heeft in de lokale colleges of raden (V N G, 2004). Als nadeel geldt echter het pettenprobleem: als bestuurder van de GGD kan iemand vóór een bepaald initiatief zijn, terwijl hij vanuit de gemeentelijke bestuursrol tegen moet zijn. Bovendien, zo wordt gesignaleerd, houdt dit model in dat het beleid vooral op het niveau van het GGD-bestuur wordt bepaald, wat remmend werkt op de gemeentelijke organisatie om zelf aan de slag te gaan met publieke gezondheidszorg. De scores op dit thema in de feitenbeschrijving hebben (opnieuw) vooral te maken met financiën:

$>$ "Hoe kan het dat de wethouder van Maastricht juicht' over de successen van Hartslag Limburg terwijl in de begroting van de GGD blijkt dat juist Maastricht haar bijdrage reduceert tot nul?" (kritiek van het CDA tijdens de raadscommissie Welzijn van Margraten, 21.04.2004, kort na het bekend worden van conclusies van het RIVM; D165)

Een ander voorbeeld dat voortkomt uit de dubbele pet constructie is het verbod dat de gemeenten via het bestuur de GGD oplegde om reserves op te bouwen voor risico-afdekking van projecten en markttaken (D 5, D 178) (zie 6.3.1). Argument achter dit verbod is dat overschotten en verliezen jaarlijks met de gemeenten worden verrekend (V N G , 2004). Echter, in tijd van bezuiniging staan gemeenten niet klaar om een oplopend tekort op te vangen; de keuze wordt dus inkrimping van projecten, waaronder $\mathrm{H}$ artslag Limburg. $\mathrm{H}$ et pettenprobleem wordt door bestuurders in de interviews spontaan erkend:

$>$ "Kijk, gemeenten zitten in een moeilijk parket, we zijn opdrachtgever en we zijn afnemer en dat maakt het voor gemeenten moeilijk. Daarnaast is het zo dat wij ook in een bestuur zitten, dus ik zit af en toe met twee petten daar: enerzijds je verantwoordelijkheid als dagelijks bestuurslid om absoluut door te pakken op dat terrein van volksgezondheid en van de andere kant wordt ik ambtelijk teruggehouden van hé, ho, wacht eens effen. Dus dat is een heel moeilijk proces, waarin je communicatief met elkaar wel door een deur moet kunnen en daar heeft het wel eens wat aan ontbroken." (81;15.07.2004) 
$>$ "Bestuurlijk is er een heel groot verschil, de GGD heeft een gemeenschappelijke regeling en daar heb je dan een heel andere rol in. Ik heb dat zelf nog eens een keer omdat ik voorzitter ben van dat bestuur, dan heb je ook veel meer contacten met de directie van de organisatie, dat ligt in de contactuele zin heel anders. Dit geeft toch een ander accent in de relaties. Dit is niet specifiek voor Maastricht. Naar de toekomst gekeken, als je het hebt over wenselijkheid, dan zou ik het prettig vinden als bestuurder, kijkende naar de GGD, daar wat verder van af moet staan, want volgens mij heb je daar beiden last van." (43;27.08.2003)

G econcludeerd moet worden dat de erkenning van de dubbele pettenproblematiek door de direct betrokkenen niet heeft geleid tot een verdere analyse of actie. $M$ en benoemt het probleem en gaat over tot de orde van de dag.

\subsubsection{Belangenstrijd actoren: conclusie}

Paragraaf 6.4 is ingeluid met de constatering dat in de feitenbeschrijving van de dimensie lokale context opvallend veel scores gelabeld zijn op de factor 'belangenstrijd tussen actoren'. N agenoeg alle scores betreffen de relatie GGD - ge meenten. In deel paragrafen is dit via triangulatie met interviews uitgediept op vijf thema's: concurrentie om beleidsprioriteit binnen de G GD -taken, 'investeren of bezuinigen', 'welzijn òf gezondheid', 'Iokaal of regionaal' en 'de dubbele pet'.

U it deze beschrijving komt naar voren dat er in de samenwerking tussen GGD en gemeenten op meerdere niveaus belangenstrijd geleverd wordt. Bovendien hebben de thema's voor belangenstrijd gemeenschappelijk dat zij het investeren in innovatie remmen. D e landelijke prioriteit uit de VTV, "investeer in gezondheidsbevordering", wordt onvoldoende serieus afgewogen tegen andere beleidsdoelen.

In het contrast met de samenwerking tussen GGD en azM valt op dat het azM bestuur in staat is om een krachtige visie op innovatie te verwoorden en daarop te sturen, zowel inhoudelijk als financieel, ook in tijd van serieuze bezuinigingen. $D$ it contrast leidt tot de vraag wat nu bepalend is voor het verschil tussen samenwerking GGD -gemeenten enerzijds en GGD -azM anderzijds. M eerdere factoren kunnen hier een rol gespeeld hebben, maar als grootste gemene deler over de vijf genoemde thema's is toch een gebrekkige regierol door gemeenten aan te wijzen. In elk van de vijf beschreven thema's van belangenstrijd tussen GGD en gemeenten gaat het in essentie om duidelijke keuzes over lokale beleidsdoelen en het toekennen van de daarvoor benodigde middelen. $D$ at is in 
essentie de regierol van de gemeente(n). H et contrast met het azM laat zien dat gemeenten die regierol veel gebrekkiger weten in te vullen. Eén van de redenen hiervoor is te vinden in de dubbele pet constructie. $\mathrm{H}$ et is immers moeilijk om als GGD -bestuurder krachtig voor investeren in innovatie te pleiten als je tegelijkertijd geacht wordt om vooral de gemeentelijke uitgaven te beperken. $M$ aar alleen verklaren is onvoldoende. Dit is een belangrijk nieuw inzicht. D e geconstateerde belangenstrijd in de lokale context duidt op een gebrekkige invulling van de regierol door gemeenten. Binnen de lokale context is dit dus een factor van betekenis; een factor die bepaalt binnen welke ruimte het verandermanagement vanuit de GGD vormgegeven kan worden. H iermee komen drie factoren op een rij te staan: leiderschap in de vorm van de regierol van gemeenten, en verandermanagement en leiderschap vanuit de G GD. In het volgende hoofdstuk wordt de relatie tussen deze drie verder uitgewerkt.

\subsection{Lokale context: conclusie}

In dit hoofdstuk is de dimensie 'lokale context' geanalyseerd. D e uitgevoerde triangulatie levert de volgende resultaten op ten aanzien van de drie factoren die binnen de dimensie worden onderscheiden.

Ten eerste wordt in paragraaf 6.2 geconcludeerd dat er in de bestaande samenwerkingsrelaties tussen G GD en gemeenten sprake is geweest van een "stroeve relatie", tekortkomingen in de communicatie tussen GGD -directeur en de bestuursvoorzitter van de gemeente M aastricht in de periode 2002 tot medio 2003, en "spanningen" in bredere zin. De gesignaleerde spanning hangt naar alle waarschijnlijkheid in belangrijke mate samen met de andere twee factoren binnen deze dimensie.

Ten tweede laat paragraaf 6.3 zien dat drie kenmerken van bedrijfsvoering een aanmerkelijk belemmerende invloed uitgeoefend hebben op de verankering van het community-deel van $\mathrm{H}$ artslag Limburg (samenwerking gemeenten, GGD en welzijnswerk): financiële transparantie, eindigheid van projecten en fusie. In 2003 gold dit met name een langslepend traject waarin de G GD moest omschakelen van input- naar outputbegroting, kritiek op de GGD vanwege gebrek aan financiële transparantie, beschuldigingen van de toenmalige GGD -directeur richting gemeenten over een jarenlange onredelijke financiële koers door gemeenten, en verschil in visie op de eindigheid van projecten samenhangend met een eenzijdig door de gemeente $M$ aastricht herziene interpretatie van GSB-regel geving. Verder kwamen in 2004 forse tekorten op meerdere bedrijfsonderdelen boven tafel, op een moment dat bestuurders besloten dat de fusie voor de gemeenten niks extra mocht kosten. Resultante was dat de GGD werd opgezadeld met een schier onmogelijke opdracht: strikt bezuinigen op het reguliere 
budget, plus de bezuiniging op de welzijnscomponent van $\mathrm{H}$ artslag Limburg intern opvangen, en tegelijkertijd de volledige samenwerkingsstructuur van $\mathrm{H}$ artslag Limburg overeind houden.

Ten derde wordt in paragraaf 6.4 geconcludeerd dat er in de samenwerking tussen GGD en gemeenten op vijf thema's belangenstrijd geleverd wordt. Die belangenstrijd leidt er onder andere toe dat er niet geïnvesteerd wordt in innovatie. Als grootste gemene deler over de vijf thema's van belangenstrijd is een gebrekkige regierol door gemeenten aan te wijzen. $D$ at is een belangrijk inzicht dat hierna uitgewerkt moet worden in relatie tot het verandermanagement en leiderschap vanuit de GGD .

D e drie factoren samenvattend wordt geconcludeerd dat de dimensie 'lokale context' ongunstig is geweest voor de bestuurlijke verankering van het community-deel van $\mathrm{H}$ artslag Limburg. D e zich opstapelende belemmeringen, bijna allemaal samenhangend met gebrek aan geld, speelden zowel in 2003 als in 2004, waardoor de druk in de tijd alleen maar toenam. De belemmeringen gelden zowel incidentele factoren (samenwerkingsrelatie, bedrijfsvoering) als structurele factoren (belangenstrijd).

D e aard van de lokale context, samen met de in hoofdstuk 5 beschreven aard van de externe factoren, laat zien dat het GGD verandermanagement in een ongunstig klimaat moest opereren. 


\section{Hoofdstuk 7 Leiderschap, regierol en verandermanagement?}

\subsection{Inleiding}

In de twee voorafgaande hoofdstukken is beschreven hoe zowel externe factoren als de lokale context ongunstig waren voor de bestuurlijke verankering van $\mathrm{H}$ artslag Limburg, met name wat betreft de samenwerking GGD, gemeenten en het welzijnswerk. Ten aanzien van de lokale context is geconcludeerd dat gemeenten tekortschoten in hun regierol. $D$ at is een belangrijk inzicht, want die regierol kan niet los gezien worden van de ruimte waarbinnen, vanuit de GGD, verandermanagement vormgegeven wordt. In hoofdstuk 3 is al geconstateerd dat aan de dimensie verandermanagement de factor leiderschap toegevoegd moet worden (zie 3.4.5). Voordat de dimensie verandermanagement nader geanalyseerd kan worden, moet dus helder gemaakt worden hoe regierol, verandermanagement en leiderschap zich tot elkaar verhouden. $\mathrm{H}$ oe is de regierol van gemeenten precies gedefinieerd? In hoeverre is er in die rol sprake van leiderschap en wat betekent dat voor de overige rollen waarbinnen leiderschap een element is? Anders gezegd, wat is de leiderschapsrol van respectievelijk de portefeuillehouder, de GGD -bestuurder, de GGD -directie en de GGD -professional? En wat voor de het 'operationele' verandermanagement vanuit de GGD?

$D$ it hoofdstuk gaat nader in op het definiëren van de begrippen regierol gemeenten, leiderschap en verandermanagement. Eigenlijk gaat het in al deze begrippen om vormen van sturing geven, in de internationale literatuur gebundeld in de algemene term 'leiderschap'. D e opbouw van dit hoofdstuk is daarom als volgt. In paragraaf 7.2 wordt eerst kort ingegaan op de verschillende theoretische visies op het begrip 'leiderschap'. In paragraaf 7.3 wordt dit uitgewerkt tot een algemene definitie. Vanuit deze definitie wordt in paragraaf 7.4 het begrip regierol gemeenten gedefinieerd. In paragraaf 7.5 worden vervolgens de begrippen verandermanagement en leiderschap vanuit de GGD gepreciseerd. Paragraaf 7.6 sluit af met een conclusie.

\subsection{Theorieën over leiderschap}

Zowel in de politiek als in het bedrijfsleven wordt al heel lang erkend dat leiderschap een belangrijke voorwaarde is voor het behalen van succes. H et thema leiderschap is tegenwoordig ook in allerlei andere sectoren van onze samenleving actueel en het onderwerp is al vele decennia onderwerp van studie. U it de litera- 
tuur blijkt dat het fenomeen leiderschap voor wetenschappers nog altijd moeilijk is te vangen in een eenduidige definitie. D eze worsteling heeft alles te maken met hoe het denken over leiderschap zich in de afgelopen decennia heeft ontwikkeld. Grofweg zijn er vier stromingen van het theoretisch denken te onderscheiden. 0 orspronkelijk werd vooral gekeken naar de karaktertrekken die 'grote' leiders zo capabel zouden maken om anderen te beïnvloeden. Vanaf de jaren veertig van de vorige eeuw werd het accent meer gelegd op het type gedrag dat effectief is in het aansturen van organisaties (Tannenbaum 1958; Likert 1961,1967). Toen bleek dat er geen universeel effectieve leiderschapsstijl aangetoond kon worden werd er vanaf de jaren zestig tevens nadruk gelegd op de relatie tussen leiderschap en omgeving, waarbij met dit laatste geduid wordt op zowel kenmerken van de medestanders (motivatie, capaciteiten) als de aard van taken en structuren (waaronder de machtsverhouding) (Situationele of contingency theorieen, Fiedler 1964). D e vierde stroom theorieen tenslotte betrekt aspecten van charisma, identificatieprocessen, waarden die leider en medestanders met elkaar delen, emoties en empowerment, in het functioneren van leiderschap (charismatisch leiderschap, Conger 1987, Shamir 1993; transformationeel leiderschap, Burns 1978, Bass \& Stogdil 1990, Yukl 1998). M et name deze laatste stroming, voortkomend uit onderzoek naar politiek leiderschap, is interessant omdat de onderzoeksresultaten uit metastudies vrij consistent lijken (Yukl, 1998). Kenmerken van succesvolle leiders ( o.a. het overbrengen van een inspirerende visie, anderen helpen bij het overwinnen van obstakels, zelf het voorbeeld geven en anderen laten delen in succes) blijken te corresponderen met de definitie van transformationeel leiderschap (het kunnen 'transformeren' c.q. inspireren en motiveren van derden). Aardig is dat in deze theorie positieve en negatieve elementen van leiderschap onderscheiden worden. Succesvol transformationeel leiderschap wordt daarbij geassocieerd met positieve kwaliteiten als gerichtheid op verandering, luisterend naar noden van mensen, in staat om kernwaarden te formuleren en te demonstreren in voorbeeldgedrag, en in staat tot zorgvuldige probleemanalyse (Tichy \& D evanna, 1986). Als onsuccesvol leiderschap wordt het zogenoemde 'laisser faire' of 'avoidance' leiderschap getypeerd: het vermijden van actie en besluitvorming, het negeren van verantwoordelijkheid en het ongebruikt laten van autoriteit (Burns 1978; Bass \& Stogdil 1990).

\subsection{Een definitie van leiderschap}

In de verscheidenheid aan definities van leiderschap zijn de elementen uit de verschillende theoretische invalshoeken herkenbaar. C entraal staat veelal: het aangeven van de koers en het beïnvloeden van individuen of groepen in de rich- 
ting van een doel, liefst een gemeenschappelijk doel, dat te maken heeft met belangrijke waarden.

$>$ "The process of influencing the behavior of an individual or a group of people toward the achievement of goals" (Hosking \& Morley 1991, p. 240)

"Leadership involves persuading other people to set aside for a period of time their individual concerns and to pursue a common goal that is important for the responsibilities and welfare of a group." (Hogan 1994, p. 493)

Tegelijkertijd wordt leiderschap over het algemeen gezien als iets dat onderscheiden dient te worden van 'management'. Waar bij management het accent gelegd wordt op hoe doelen bereikt kunnen worden, heeft leiderschap meer te maken welke doelen gekozen moeten worden. Voor management is het essentieel dat die doelen ook gehaald worden, voor leiderschap niet. Belangrijker bij leiderschap is dat consistent gestreefd wordt naar verandering en dat daarbij de relatie tussen de leider en zijn medestanders blijft bestaan (Rost, 1993, p. 116). H ier tellen vooral de eigenschappen van de leider zoals verwoord in het concept van transformationele leiderschap. Commitment, betrouwbaarheid en het ondernemen van een gezamenlijke actie zijn even belangrijk als het resultaat (Gini 1995, p. 148). D ie gezamenlijkheid moet niet voortkomen uit macht maar uit gezag, uit het inspireren en engageren van medestanders.

Vanuit deze visie wordt leiderschap ook wel gezien als een kwaliteit van management. Immers, om effectief te zijn moet een manager ook over leiderschap beschikken. $\mathrm{H}$ et is echter helderder om leiderschap en management te zien als aparte vaardigheden die vaak beide vereist zijn in een leidinggevende rol.

Een definitie die goed lijkt aan te sluiten bij de essentie uit de vier theoretische stromingen is de definitie die door Rost wordt gehanteerd:

$>$ "Leadership is an influence relationship among leaders and followers who intend real changes that reflect their mutual purposes." (Rost 1993, p. 102)

Rost licht daarbij toe dat de relatie tussen leider en medestanders mede bepaald wordt door de behoeften en mogelijkheden in een bepaalde omgeving in een bepaalde tijdsperiode (Gini, p. 147).

Voor het doel van deze paragraaf, het definiëren van leiderschap ten behoeve van de analyse van de $\mathrm{H}$ artslag Limburg casus, is het belangrijk om een keuze te 
maken die past bij de setting van de casus. D e op een uitgebreide meta-analyse gebaseerde definitie van Rost bevat duidelijk veel bruikbare elementen: oog voor 'koersen op echte verandering', 'passend binnen gedeelde gemeenschappelijke doelen' en de visie op leiderschap als een 'wederkerige relatie'. Verder is het concept van tranfformationed versus avoidance leiderschap bruikbaar omdat dit positieve en negatieve elementen omvat in relatie tot het al dan niet kunnen transformeren' (inspireren en motiveren) van derden; dit ligt heel dicht aan tegen het creëren van draagvlak, en gaat zelfs iets verder.

Voor de casus wordt de aanwezigheid of afwezigheid van leiderschap daarom als volgt gedefinieerd:

$>$ Leiderschap is een wederzijds beïnvloedende relatie tussen een leider en zijn volgers, gericht op het bereiken van tastbare resultaten die passen binnen de gedeelde gemeenschappelijke doelen. De aanwezigheid van leiderschap wordt gekenmerkt door het formuleren van doelen en daarvoor benodigde tussenstappen en het consequent inzetten van de eigen autoriteit in de richting van de uitgezette koers. Daarentegen wordt gebrek aan leiderschap gekenmerkt door het vermijden van actie en besluitvorming, het negeren van verantwoordelijkheid en het ongebruikt laten van autoriteit.

Een element uit de definitie van Rost dat specifiek past in de relatie gemeente GGD, in tegenstelling tot de overige relaties in de casus, is de betiteling van 'volgers' ("followers"). Binnen het veld van de openbare gezondheidszorg is er alleen in de relatie gemeente - GGD sprake van hiërarchie. En ook daar is nog het nodige over te nuanceren: wie leidt nu precies wie op welke niveau's? D it punt wijst daarom op de noodzaak om vanuit deze algemene definitie eerst de regierol van de gemeenten nader te definiëren, alvorens verder ingegaan kan worden op de rol van leiderschap vanuit de GGD.

\subsection{Definitie van de regierol van gemeenten}

D e basis voor de taken en verantwoordelijkheden van de gemeente op het terrein van de gezondheidsbevordering is vastgelegd is in de W et collectieve preventie volksgezondheid (W CPV). In die wet is de rol van de gemeente als volgt in een drietal artikelen verwoord:

- De gemeenteraad bevordert de totstandkoming en de continuïteit van en de samenhang binnen collectieve preventie alsmede de onderlinge afstemming tussen deze collectieve preventie en de curatieve gezondheidszorg. 
- Ter verwezenlijking hiervan draagt de gemeenteraad in ieder geval zorg voor het bijdragen aan opzet, uitvoering en afstemming van preventieprogramma's, met inbegrip van gezondheidsvoorlichting en -opvoeding.

- Ter uitvoering van bij of krachtens deze wet opgedragen taken dragen de gemeenteraden zorg voor de instelling en instandhouding van gemeentelijke gezondheidsdiensten. (Staatsblad, 2002a)

D e opdracht uit de W CPV aan gemeenten om "sturing te geven aan afstemming en samenwerking tussen de vele betrokken partijen" wordt door de VN G samengevat als "regisseur zijn in het lokal e gezondheidsbeleid" (V N G, 2006a en 2006c). $0 \mathrm{~m}$ dit concreet te maken is de gemeente op basis van de W CPV sinds 2003 verplicht om haar beleid vierjaarlijks vast te leggen in een nota Gezondheidsbeleid.

Tegelijkertijd beschrijft de VN G de regierol van gemeenten in algemene zin als een "containerbegrip" (V N G, 2002). D e VN G geeft aan dat de invulling van de regierol verschilt afhankelijk van lokale omstandigheden: 0.a. de aard van de problematiek, aantal betrokken partijen, hoe groot is de kracht van gemeente en andere actoren, en waar houdt het stellen van kaders door gemeenten op en moet ruimte gegeven worden aan burgers of marktpartijen. D esal niettemin beschrijft de VNG de regierol als:

\footnotetext{
$>$ "een belangrijke rol spelen in het ondersteunen van initiatieven, het doorvertalen naar beleid en het formuleren van randvoorwaarden". Daar wordt nog aan toegevoegd "dat er met de betrokken partijen overeenstemming moet zijn over de urgentie en noodzaak van ingrepen". (VNG, 2002)
}

In de visie van de Raad voor het O penbaar Bestuur heeft de regiefunctie van gemeenten betrekking op situaties waarin het lokale bestuur op grond van hoge re regelgeving of eigen politieke taakstellingen de verantwoordelijkheid heeft voor de totstandkoming van beleid, maar daarbij in sterke mate afhankelijk is van de medewerking van anderen (burgers, intermediaire organisaties en andere overheden)(Raad voor het O penbaar Bestuur, 1999).

$U$ it deze beschrijvingen wordt duidelijk dat de regierol van gemeenten verschillende interpretaties kent, mede ingegeven door de inhoudelijke en lokale context. $D$ aarnaast blijkt de regierol van gemeenten mede afhankelijk van de kaders die de rijksoverheid daarvoor stelt. (V N G, 2002; M inisterie van Binnenlandse Zaken, 2006) Een vrij recent overzicht van de verschillende inzichten uit onderzoek betreffende de regierol van gemeenten definieert het begrip regie als volgt: 
$>$ "Een bijzondere vorm van sturen die is gericht op de afstemming van actoren, hun doelen en handelingen tot een meer samenhangend geheel, met het oog op een bepaald resultaat." (Min. BiZa, 2006, p.9)

In dit overzicht wordt een onderscheid gemaakt tussen drie niveaus van regievoering door gemeenten: het bestuurlijke niveau, de interne regie en het uitvoe ringsniveau.( $\mathrm{M}$ in. BiZa, 2006, p.13) In de toelichting op deze niveaus wordt een duidelijke koppeling gelegd tussen de bestuurlijk en interne regie.

"Regievoering is alleen mogelijk op basis van een duidelijke visie, lokale ambitie en mogelijkheden. Zonder deze ambitie weten partners niet waar ze aan toe zijn (... ). D aarom moet een gemeente haar ambitie vertalen in een politiek-bestuurlijke en ambtelijke prioriteitstelling. (...) Regie begint met bevlogenheid en durf van een wethouder of burgemeester. (... ) D it betekent dus dat er draagvlak gecreëerd moet worden bij het bestuur en het ambtelijk apparaat." ( $M$ in. BiZa, 2006, p.31) Als al gemene voorwaarde voor de uitvoerende regie wordt 0.a. genoemd het maken van concrete afspraken met alle partijen (over het gezamenlijk resultaat, het primair proces en de capaciteit inclusief tijd en kwaliteit die wordt geleverd) en het respecteren van de competenties van partners. $0 p$ het terrein van het gezondheidsbeleid wordt aangegeven dat de uitvoerende regie grotendeels ondergebracht is bij de GGD, met dien verstande dat de beleidsformatie hierbinnen zowel bij gemeenten als ook soms bij GGD'en is ondergebracht. (V N G, 2006c, p. 9-12)

$\mathrm{N}$ aast het onderscheid in drie niveaus wordt in dit document gewezen op een onderscheid in twee belangrijke kenmerken van regie, namelijk 'doorzettingsmacht' en 'eigen script'. D oorzettingsmacht betreft de mate waarin de regisseur andere partijen zijn wil op kan leggen en eigen script betreft de mate waarin de regisseur zijn eigen koers kan bepalen. Waneer beide kenmerken sterk aanwezig zijn kan de regierol een meer sturend en beheersmatig karakter krijgen; bij afwezigheid van beide kenmerken ligt een meer visionaire en faciliterende regierol voor de hand.

Vertalen we dit naar het terrein van de publieke gezondheid, specifiek het deelterrein gezondheidsbevordering, dan is duidelijk dat doorzettingsmacht en eigen script daar slechts zeer beperkt aanwezig zijn. Er is weinig afdwingbare wet- en regelgeving en lokale partijen dienen vooral 'verleid' te worden tot een gezamenlijk script. $D$ e regierol van de gemeente zal in deze dan ook een meer faciliterend karakter moeten hebben. D ie positionering wordt door de tekst van de W CPV bevestigd, aangezien gekozen is voor de bewoordingen: "de gemeente bevordert de totstandkoming ... (etc.)" en "Ter verwezenlijking hiervan draagt de gemeenteraad zorg voor het bijdragen aan opzet ... (etc.)" (Staatsblad, 2002. 
WCPV, paragraaf 2, resp. artikel 2.1 en 2.2c). D eze formuleringen laten evident ruimte aan andere partijen om een eigen bijdrage aan het script te leveren. $\mathrm{H}$ et laat tevens ruimte aan de professionele organisatie aan wie de gemeenteraden krachtens artikel 5.1 de uitvoering hebben opgedragen, om haar professionele bijdrage aan het script te leveren.

$0 p$ basis van het bovenstaande en de eerdere al gemene definitie van leiderschap komen we tot een definitie van een meer faciliterende regierol van gemeenten in het kader van lokaal gezondheidsbeleid:

$>$ De regierol van gemeenten betreft een bijzondere vorm van sturen die is gericht op de afstemming van actoren, hun doelen en handelingen tot een meer samenhangend geheel, met het oog op een bepaald resultaat. Deze regievoering vereist een duidelijke gemeentelijke visie, die vertaald wordt in een politiek-bestuurlijke en ambtelijke prioriteitstelling, evenals het vaststellen van de daarvoor benodigde en beschikbare gemeentelijke middelen.

Daarentegen wordt gebrek aan regierol gekenmerkt door het vermijden van besluitvorming over politiek-bestuurlijke en ambtelijke prioriteiten, het negeren van verantwoordelijkheid voor het vaststellen van benodigde middelen en het ongebruikt laten van autoriteit.

D eze definitie is van toepassing op de gemeenten in de casus $\mathrm{H}$ artslag Limburg, en daarmee op de portefeuillehouders en raadsleden die betrokken zijn bij het thema gezondheid. O verigens zijn het merendeels deze zelfde portefeuillehouders en raadsleden die gezamenlijk het $A B$ en $D B$ van de GGD -zzl vormen. De directeur van de GGD -zzl is geen lid van het bestuur, maar is formeel haar ambtelijk secretaris. ${ }^{11}$

D e definitie vertoont overeenkomsten met de definitie van leiderschap uit de vorige paragraaf, maar verschaft wel specifieke detaillering en daarmee een beter

1) “Aan het bestuur (AB) van de GGD-zzl worden ten behoeve van de behartiging van de aan de dienst opgedragen taken dezelfde bevoegdheden toegekend als de besturen van de gemeenten terzake hebben."

"De ambtelijk secretaris van het Algemeen en Dagelijks Bestuur is hij die de functie van directeur bekleedt, als bedoeld in artikel 25."

“De ambtelijk secretaris woont de vergaderingen van het Algemeen en Dagelijks Bestuur bij en heeft daarin een adviserende, raadgevende stem." (D213) 
onderscheid. De hier gedefinieerde regierol betreft vooral het bestuurlijke en interne niveau waarop beleidsdoelen en middelen vastgesteld worden. $\mathrm{H}$ et in de literatuur onderscheiden uitvoeringsniveau van regie wordt hier bewust niet opgenomen in de definitie. Dit laat ruimte aan andere actoren, inclusief de GGD, om leiderschap te tonen bij het invullen van de door gemeenten vast te stellen kaders. D it past bij zowel de literatuur als de praktijk in de onderhavige casus waarin de samenwerking vanuit de GGD al vanaf 1994 werd opgebouwd en onderhouden.

\subsection{Definitie van verandermanagement en leiderschap vanuit de GGD}

In de vorige paragraaf is de regierol van gemeenten onderbouwd en gedefinieerd. In lijn met artikel 5.1 van de W CPV (zie 7.4) laat deze definitie ruimte voor invulling van uitvoerende taken en uitvoerende regie aan de GGD. In deze paragraaf wordt de rol van de GGD uitgewerkt.

In het WIZ-model dient de regierol van gemeenten geplaatst te worden binnen de dimensie lokale context. $D$ it is inherent aan de centrale vraagstelling, waarbij de dimensie verandermanagement is gedefinieerd als de acties die vanuit de GGD worden ondernomen om de verankering van $\mathrm{H}$ artslag Limburg te bevorderen (zie 3.2). Als actoren binnen de dimensie verandermanagement zijn alle GGD medewerkers gedefinieerd die in de geregistreerde gebeurtenissen actief hebben bijgedragen aan veranderacties: de directeur, een senior staflid, het afdelingshoofd, de clustercoördinator, de projectleider en een senior G VO -er. D eze definitie van verandermanagement overlapt daarmee grotendeels met het in de vorige paragraaf genoemde derde niveau van regievoering door gemeenten: de uitvoerende regi erol. In de casus $\mathrm{H}$ artslag Limburg gaat het vanuit het GGD -perspectief vooral om het creëren van draagvlak bij bestuurders van $D B$ en $A B$ voor het belang van gezondheidsbevordering. De uitvoerende regie krijgt hier de vorm van een professionele motivatie om de andere regieniveaus (bestuurlijk niveau en intern gemeentelijk niveau) te beïnvloeden. D eze beïnvloedingscomponent van de uitvoerende regierol noemen we hier 'verandermanagement'.

$0 \mathrm{~m}$ het verandermanagement vanuit de GGD grijpbaar te maken wordt er onderscheid gemaakt in verschillende typen van acties. $D$ it onderscheid is beschreven in termen van vijf factoren binnen de dimensie verandermanagement: 'visie', 'sociaal ondernemerschap', 'beïnvloedingsstrategieën', 'netwerkontwikkeling' en 'leiderschap'. D e factor leiderschap is toegevoegd op basis van validering van het model met een expertpanel (zie 3.4.5 en figuur 3.3). Verder is relevant dat niet elke factor door bovengenoemde actoren in gelijke mate uitgevoerd 
wordt. $\mathrm{H}$ et is duidelijk dat van de GGD -actoren, het met name de directeur van de GGD is die de contacten met de partners op bestuurlijk niveau vorm geeft. $D$ it is het niveau waarop het leiderschap vanuit de GGD in ieder geval bepaald moet worden. D e realisatie van de overige vier factoren, - visie, sociaal ondernemerschap, beïnvloedings-strategieën en netwerkontwikkeling - zijn daarnaast samen te vatten als het 'operationele' verandermanagement. Alle GGD actoren dragen hier aan bij, zij het dat voor de niet-direcieleden het accent ligt bij het operationele niveau. Voor de directeur ligt het accent op het leiderschap. $D$ e analyse van de factor leiderschap binnen de dimensie verandermanagement wordt daarom gefocust op de rol van de directeur.

Voor de casus wordt de aanwezigheid of afwezigheid van leiderschap vanuit de GGD daarom als volgt gedefinieerd:

$>$ Leiderschap vanuit de $G G D$ is een wederzijds beinvloedende relatie tussen de directeur en andere actoren, gericht op het bereiken van tastbare resultaten die passen binnen de met gemeenten en derden gedeelde gemeenschappelijke doelen. De aanwezigheid van leiderschap wordt gekenmerkt door het formuleren van doelen en daarvoor benodigde tussenstappen en het consequent inzetten van de eigen autoriteit in de richting van de uitgezette koers. Daarentegen wordt gebrek aan leiderschap gekenmerkt door het vermijden van actie en besluitvorming, het negeren van verantwoordelijkheid en het ongebruikt laten van de professionele autoriteit.

Kern van de gekozen definitie is de focus op de rol van de directeur van de GGD bij het formuleren van doelen en de mate van inzet van de eigen autoriteit om die doelen te bereiken, ondanks eventuele tegenwind.

\subsection{Conclusie}

In de vorige paragrafen is ingegaan op algemene theorieën over leiderschap en is een specifieke uitwerking geformuleerd ten aanzien van de regierol van gemeenten en de rol van leiderschap en verandermanagement vanuit de GGD . $\mathrm{G}$ econcludeerd is dat de regierol van gemeenten focust op zowel het bestuurlijke niveau waarop beleidsdoelen en middelen vastgesteld worden, als op het ambtelijke niveau waarop de interne regie vorm moet krijgen. H et uitvoerende niveau van de regierol heeft de gemeente in belangrijke mate ondergebracht bij de GGD.

Kern van de gekozen definitie voor leiderschap vanuit de GGD is de focus op 
de strategische rol van de directeur van de GGD bij het formuleren van (uitvoerende) doelen en de mate van inzet van de eigen autoriteit om die doelen te bereiken; dit ondanks de tegenwind die voortkomt uit de in hoofdstuk 6 beschreven belangenstrijd tussen GGD en gemeente.

D e consequenties van deze definities voor het W IZ-model zijn weergegeven in figuur 7.1. In de figuur is de regierol van gemeenten als factor opgenomen in de lokale context. D e nauwe relatie tussen verandermanagement en leiderschap vanuit de GGD enerzijds en de regierol van gemeenten anderzijds is weergegeven door de toevoeging van een dubbele pijl. Complementair aan de factor leiderschap worden de overige factoren binnen de dimensie verandermanagement gebundeld onder de noemer 'operationeel verandermanagement'.

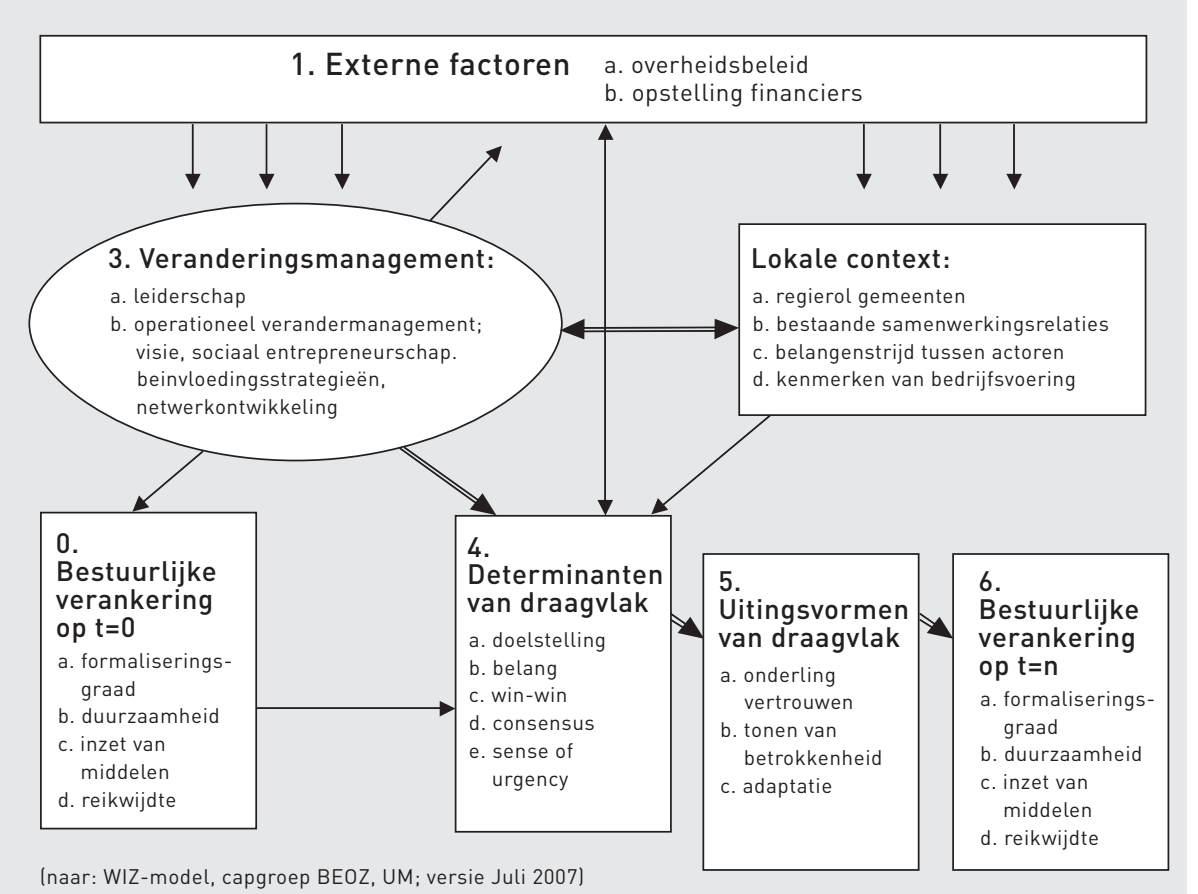

Figuur 7.1 WIZ-model voor bestuurlijke verankering van samenwerking tussen de GGD en haar omgeving. Versie na analyse dimensie lokale context ljuli 2007); toegevoegd is de factor 'regierol gemeenten'. 


\section{Hoofdstuk 8 Verandermanagement en leiderschap}

\subsection{Inleiding}

In de hoofdstukken 5 en 6 is beschreven hoe zowel externe factoren als de lokale context ongunstig werkten op de bestuurlijke verankering van $\mathrm{H}$ artslag Limburg, met name wat betreft de samenwerking G GD, gemeenten en het welzijnswerk. In hoofdstuk 7 zijn de begrippen regierol gemeenten als onderdeel van lokale context en leiderschap als onderdeel van verandermanagement nader uitgewerkt en geplaatst binnen het W IZ-model. $0 p$ basis van deze definiëring kan in dit hoofdstuk de analyse van de dimensie verandermanagement beschreven worden.

'Verandermanagement' is gedefinieerd als de acties die vanuit de GGD werden ondernomen om de verankering van $\mathrm{H}$ artslag Limburg te bevorderen. Binnen de dimensie worden vijf factoren onderscheiden: 'visie', 'sociaal ondernemerschap', 'beïnvloedingsstrategieën', 'netwerkontwikkeling' en 'leiderschap'. De eerste vier factoren worden samengevat onder de noemer 'operationeel verandermanagement'. Als actoren binnen de dimensie zijn alle GGD medewerkers gedefinieerd die actief hebben bijgedragen aan veranderacties: de directeur, een senior staflid, een clustercoördinator, de projectleider en een senior GVO -er. De factor leiderschap betreft als actor specifiek de rol van de directeur (zie 7.5). Bij de validering van het model is geconstateerd dat het onderscheid tussen de deelfactoren van verandermanagement soms lastig te trekken is (zie 3.4.5). D it heeft gevolgen voor de analyse. Een aanpak waarbij elke 'factor' apart geanalyseerd wordt, analoog aan hoofdstuk 5 en 6 , is niet voldoende. D e beschrijving en beoordeling van de verandermanagementacties, kortweg veranderacties, moet uiteindelijk plaatsvinden tegen de achtergrond van de situatie. Een opsomming van aantallen en soorten acties leidt immers nog niet tot inzicht in hoeverre de acties adequaat waren, dat wil zeggen bijdroegen aan draagvlak en bestuurlijke verankering (zie deelvraagstellingen 5 en 7, paragraaf 3.3). Voor dat inzicht zijn context, timing en eventuele effecten op draagvlak en verankering essentieel. $0 \mathrm{~m}$ die reden is in dit hoofdstuk gekozen voor een iets aangepaste werkwijze. Paragraaf 8.2 geeft een overzicht op de aantallen gebeurtenissen per factor uit de feitenbeschrijving, als opmaat voor 8.3. Paragraaf 8.3 brengt hier meer betekenis in aan door een chronologische beschrijving van de belangrijkste veranderacties per jaartal. In deze paragraaf wordt de tijdreeksanalyse gecompleteerd door triangulatie met data uit interviews en enquêtes; bij deze triangulatie wordt tevens bekeken in hoeverre de veranderacties effect sorteerden op draagvlak en veran- 
kering. Paragraaf 8.4 sluit af met een discussie over de gevonden resultaten en een conclusie.

\subsection{De feitenbeschrijving: een overzicht van de scores}

$0 p$ basis van de feitenbeschrijving is in figuur 8.1 het totaal aantal gebeurtenissen binnen de dimensie verandermanagement weergegeven. In de figuren 8.2 $\mathrm{t} / \mathrm{m} 8.6$ is dit opgesplitst naar de vijf factoren. Zoals toegelicht in paragraaf 3.4.3 komen de totaal scores van de aantallen gebeurtenissen van de figuren 8.2 t/m 8.6 bij elkaar opgeteld iets hoger uit dan de totaalscore van 8.1 (118 resp. 101); dit omdat gebeurtenissen soms in twee of meer categorieën zijn meegeteld.

Aan figuur 8.1 valt op dat een groot aantal acties van de G GD plaats vond in 2003, en een stuk minder in 2004 en 2005. Blijkbaar was 2003 een cruciaal jaar. Kijkend naar de vijf deelfactoren blijkt dat de hoge scores vooral de factor sociaal ondernemerschap en beïnvloedingsstrategieën betreffen (resp. 26 en 15 positieve scores in 2003). Blijkbaar zijn deze factoren van verandermanagement door de GGD veelvuldig ingezet. In algemene zin valt verder op dat de meeste gebeurtenissen zijn beoordeeld als bevorderend. $0 \mathrm{p}$ de achtergronden van de negatieve scores wordt hieronder apart ingegaan. In zijn algemeenheid kan ten aanzien van negatieve scores gezegd worden dat acties van het management van de GGD (directeur, clustercoördinator) meerdere belangen moeten dienen, en dus soms als negatief voor de verankering van $\mathrm{H}$ artslag Limburg zijn beoordeeld.

\subsubsection{Visie}

Figuur 8.2 laat de scores zien op de factor visie: het aantal gebeurtenissen waarbij het aanreiken van informatie over belang en opzet van de samenwerking centraal stond. De positieve scores, negen in totaal, betreffen bijeenkomsten met derden (enerzijds ambtenaren, portefeuillehouders en raadsleden, anderzijds medewerkers van zorgverzekeraar, huisartsen, specialisten) waar besproken wordt hoe $\mathrm{H}$ artslag Limburg kan passen binnen de mogelijkheden voor lokaal beleid, respectievelijk het eerstelijns beleid en het ziekenhuis beleid. D e scores op deze factor overlappen deels met die van 'sociaal ondernemerschap', waar het accent meer ligt op het identificeren van zichtbare en onzichtbare actoren of meningen. Wel specifiek voor de factor visie is de score betreffende een beleidsnotitie die door GGD en afdeling Cardiologie gezamenlijk wordt geschreven. D eze notitie vervult een cruciale rol in het verdere verankeringsproces (zie 8.3.2). D e 
negatieve scores op de factor visie in 2003 en 2004 staan voor gebeurtenissen waarin er door de GGD, onder druk van financiële tekorten, ingeleverd wordt op de oorspronkelijke visie.

\subsubsection{Sociaal ondernemerschap}

D e factor sociaal ondernemerschap staat voor bijeenkomsten die de G GD belegde voor overleg met partners, specifiek met als doel om zichtbare en onzichtbare actoren en meningen te identificeren en eventueel te lobbyen voor kansrijke alternatieven (zie bijlage 1 en paragraaf 3.2).

\section{Verandermanagement}

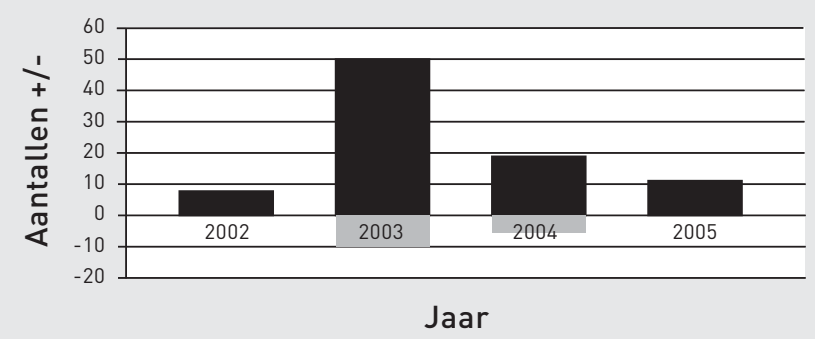

Positief

Negatief

Figuur 8.1 Totaal aantal gebeurtenissen Verandermanagement van de feitenbeschrijving

3a. Visie

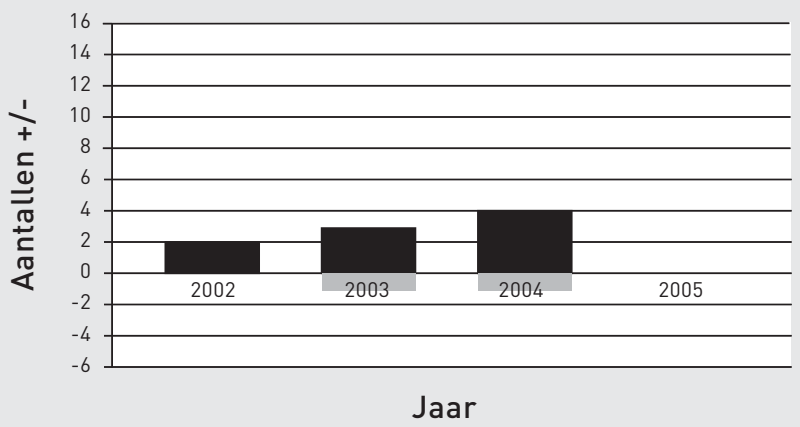

Positief

Negatief

Figuur 8.2 Aantal gebeurtenissen van de factor Visie 


\section{3b. Sociaal ondernemerschap}

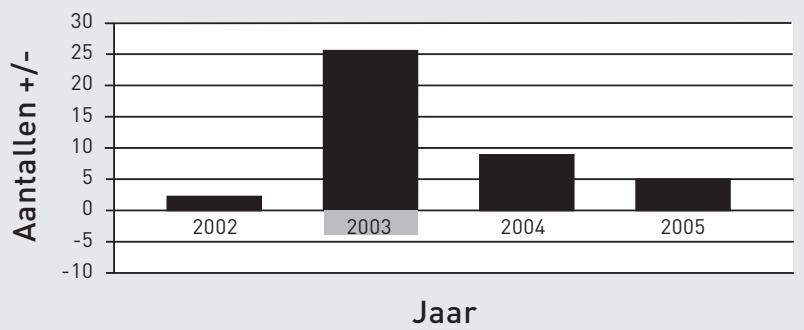

Positief

Figuur 8.3 Aantal gebeurtenissen van de factor Sociaal ondernemerschap

\section{3c. Beïnvloedingsstrategieën}

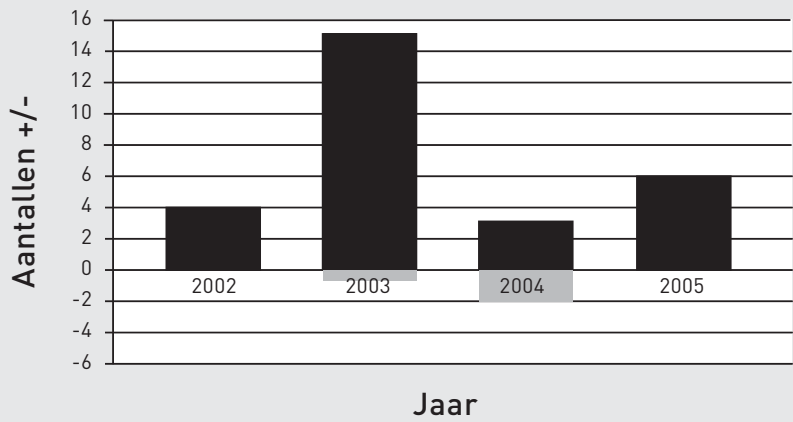

Positief

Negatief

Figuur 8.4 Aantal gebeurtenissen van de factor Beïnvloedingsstrategieën

\section{3d. Netwerkontwikkeling}

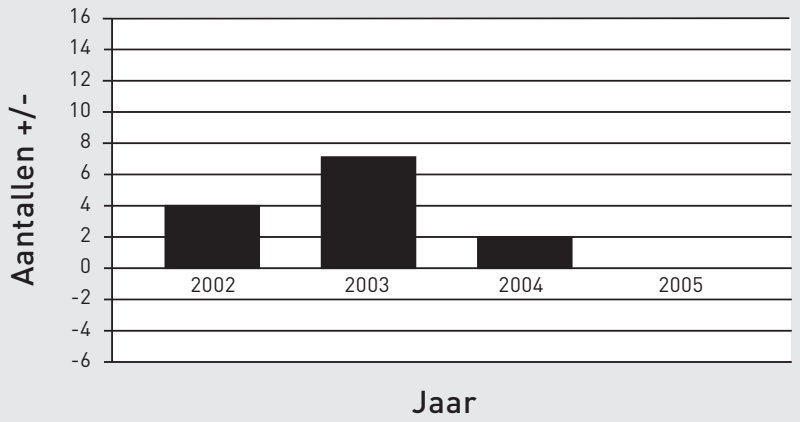

Positief

Negatief

Figuur 8.5

Aantal gebeurtenissen van de factor Netwerkontwikkeling 
3e. Leiderschap

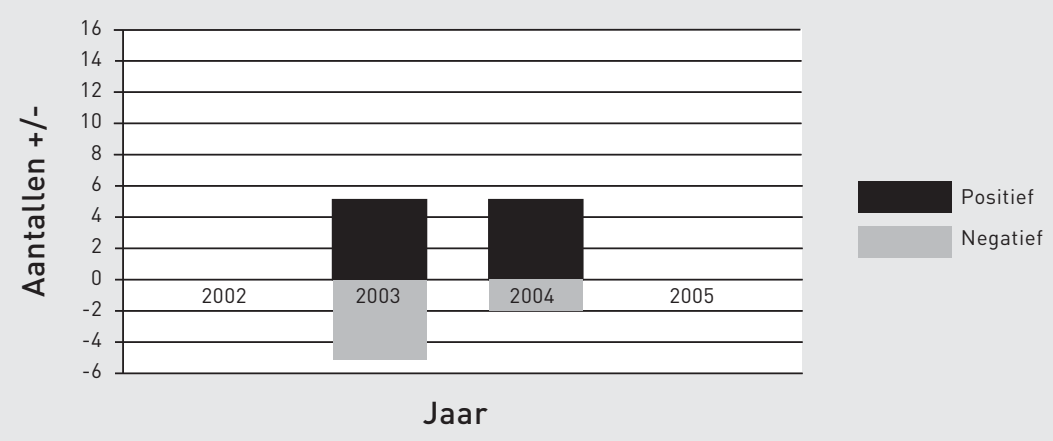

Figuur 8.6 Aantal gebeurtenissen van de factor Leiderschap

Figuur 8.3 laat zien dat ruim veertig van dit type gebeurtenissen is gedocumenteerd. Vooral in 2003 vond dit veelvuldig plaats zowel intern binnen de GGD, als bij partners in de regio, en zelfs bij landelijke actoren. $\mathrm{H}$ ieronder vallen 0.a. acties om dreigende negatieve beeldvorming te pareren, als ook een aantal grote bijeenkomsten op de GGD (30 - 90 deelnemers). De als negatief gescoorde gebeurtenissen betreffen het stopzetten van acties om de samenwerking met huisartsen te continueren, pogingen in september 2003 om coalitie te sluiten met afdeling Sportzaken van de gemeente $M$ aastricht (resultaat in de nota Sport is minimaal), en een gemiste kans om de raadscommissie van $M$ aastricht bij te wonen (brief ligt ongeopend op directiesecretariaat van de GGD).

\subsubsection{Beïnvloedingsstrategieën}

Figuur 8.4 geeft een beeld van gehanteerde beïnvloedingstrategieën: de positieve scores, achtentwintig in totaal, betreffen presentaties van resultaten aan raadscommissies, productie van voortgangsrapportages en nieuwsbrieven, gereal iseerde artikelen in kranten en in bladen van partnerorganisaties, het winnen van een landelijke prijs, vermelding in landelijke nota's, presentaties op congressen. D e negatieve score in 2003 betreft foutieve informatie die door de afdeling financiën van de GGD verstrekt wordt aan gemeenten waardoor een beeld ontstaat van steeds groeiende financiële claims vanuit $\mathrm{H}$ artslag naar de gemeente (dit beeld wordt overigens succesvol gecorrigeerd). D e negatieve score in 2004 betreft 0.a. de conclusie van de directeur van het welzijnswerk dat de GGD "niet in staat is om diensten van het welzijnswerk in te kopen". 


\subsubsection{Netwerkontwikkeling}

Figuur 8.5 betreft de netwerkontwikkeling op operationeel niveau: het benutten van vaak bilaterale contacten tussen professionals, managers, ambtenaren en raadsleden. $\mathrm{H}$ et zijn juist deze contacten die er in 2003 voor zorgen dat $\mathrm{H}$ artslag Limburg opgenomen wordt in de gemeentelijke (concept)nota's. D e positieve scores betreffen verder 0. .a. de gemeente $M$ argraten waar met verschillende ambtenaren en raadsleden nauw wordt overlegd en samengewerkt. $D$ ankzij dit netwerk kan de GGD in samenwerking met de ambtenaar, maximaal anticiperen op kritische vragen vanuit de raadscommissie. D e ambtenaar vervult daarin het knooppunt tussen de verschillende netwerken.

\subsubsection{Leiderschap}

In figuur 8.6 zijn de scores op de factor leiderschap weergegeven. D eze factor is pas later in de studie toegevoegd (zie 3.4.5). Kern van de gehanteerde definitie betreft het formuleren van doelen, tussenstappen en het consequent inzetten van de eigen autoriteit, als onderdeel van het verandermanagement vanuit de GGD (zie 7.3). Een niet-optreden op momenten dat dit aannemelijk lijkt of gevraagd wordt, is als negatieve score geteld. O pvallend in de figuur is het relatief grote aantal negatief beoordeelde gebeurtenissen. Als enige factor binnen de dimensie verandermanagement zijn de negatieve scores hier bijna even tal rijk als de positieve.

D e scores van 2003 betreffen het cruciale laatste kwartaal. Positief gescoord is een succesvol spoedoverleg van directeur en projectleider met een opponerende portefeuillehouder om misverstanden uit de weg te ruimen (D 101; zie 4.3.3 en 6.4.2), de bijeenkomst voor bestuursleden en raadsleden waarop de directeur $H$ artslag Limburg presenteert als nieuwe standaard binnen de wettelijke GGD taken (D 104), en de 'brandbrieven' die verstuurd worden naar gemeente M aastricht en Valkenburg (D 119, D 124). N egatief is gescoord: besluiten van de directeur om a) geen coalitie samen met het welzijnswerk te initiëren ter bestrijding van de bezuiniging op de GSB-subsidie (D 97), en om b) geen nieuwsbrief over $\mathrm{H}$ artslag Limburg uit te brengen (D 99). Verder zijn negatief gescoord de kritiek van een portefeuillehouder dat de GGD onvoldoende zorg droeg voor inbedding van $\mathrm{H}$ artslag Limburg in het reguliere GGD -beleid (D 101), en de uitspraak van de Inspectie dat het de taak van de GGD is om bestuurders te overtuigen (D 114).

D e scores van 2004 betreffen in positieve zin de kritiek van de directeur dat gemeenten geen duidelijke keuzes maken, en het daarop volgende initiatief van de directeur om de belangrijkste actoren bij elkaar te krijgen (D 123, D 127). 
N egatief scoort in 2004 dat de G GD directeur geen actie onderneemt wanneer dit initiatief plots door de bestuursvoorzitter wordt afgeblazen (D 146). Positief scoort verder het vasthoudende optreden van de G GD in M argraten (D 149, D 153, D 155, D 158, D 163, D 169).

Geconcludeerd wordt dat de GGD acties heeft ondernomen op alle factoren die binnen de dimensie verandermanagement worden onderscheiden. $M$ et name in 2003 is de GGD zeer actief in sociaal ondernemerschap (het bij elkaar brengen van actoren en zoeken naar oplossingen) en de toepassing van allerlei beïnvloedingsstrategieën. D e factor leiderschap springt er uit vanwege negatieve scores in 2003 en 2004.

$M$ et deze beschrijving is een eerste indruk gegeven. $D$ e volgende paragraaf plaatst de belangrijkste veranderacties nadrukkelijker in hun context.

\subsection{De belangrijkste veranderacties: de resultaten per jaartal}

\subsubsection{De belangrijkste veranderacties in 2002}

D e feitenbeschrijving laat zien dat er in 2002 zeven gebeurtenissen zijn gescoord (figuur 8.1). D e gebeurtenissen betreffen contacten tussen GGD en medewerkers van VWS, overleg tussen GGD en gemeente ambtenaren en een bijeenkomst voor raadsleden op de GGD. O ok geteld zijn de artikelen in de Volkskrant en Dagblad D e Limburger over $\mathrm{H}$ artslag Limburg in relatie tot de pas verschenen VTV 2002. D oel van de contacten met VW S is om via het ministerie de gemeenten te bereiken. De basis hiervoor is al eerder gelegd, o.a. door eerdere publicaties over H artslag Limburg (Jansen et al., 2002). Een jaar later, oktober 2003, blijkt het resultaat positief: $\mathrm{H}$ artslag Limburg wordt ook in de preventienota van VW S aangehaald. D e timing van de veranderacties lijkt goed: 15 november verschijnt de VTV-2002, de krantenartikelen volgen kort daarop (22 en 25 november) en vallen samen met de bijeenkomst voor raadsleden ( 25 november). D e impact van de acties op de aanwezig wethouders en raadsleden blijft echter moeilijk in te schatten, 0.a. vanwege een hoge non-respons op de evaluatievragen (zie 4.3.1). Een impact wordt wel geregistreerd van het werkoverleg met ambtenaren van de gemeente Eijsden. D aar lijkt het draagvlak toe genomen getuige de conclusie dat $\mathrm{H}$ artslag Limburg "een goede 'fit' heeft met het lokale beleid". 0 ok het gezamenlijk bespreken van mogelijkheden voor financiering voor 2004 bevestigt de positieve houding van de ambtenaren (D 28). 
Samenvattend: inhoud, vorm en timing van de veranderacties in het laatste kwartaal van 2002 worden beoordeeld als adequaat. D it omdat in korte tijd veel kansen zijn gecreëerd om raadsleden, ambtenaren en wethouders te informeren en alle beschikbare kansen succesvol zijn benut.

\subsubsection{De belangrijkste veranderacties in eerste helft 2003}

In 2003 zijn in totaal 60 gebeurtenissen gescoord, waarvan 50 positief en 10 negatief (figuur 8.1). $\mathrm{N}$ egen van de tien negatieve gebeurtenissen betreffen de tweede helft van 2003 (paragraaf 8.3.3). Begin 2003 betreffen de positieve scores vooral contacten met ambtenaren, artikelen in landelijke en lokale pers, presentaties voor raadscommissies en de lobby binnen het azM .

Resultaat van de ambtelijke contacten is dat de GGD advies krijgt op welke manier $\mathrm{H}$ artslag Limburg gecontinueerd zou kunnen worden ondanks de dreigende gemeentelijke bezuinigingen. Q ua veranderactie betekent dit dat het project $\mathrm{H}$ artslag Limburg een product moet worden, en verschoven wordt van de kolom 'facultatief' naar de kolom 'wettelijk verplicht' (D 39). In korte tijd wordt het management van de GGD hiervan overtuigd; beargumenteerd wordt dat de nieuwe W CPV gemeenten verplicht om GVO vorm te geven, en dat $\mathrm{H}$ artslag Limburg daar op wetenschappelijk verantwoorde wijze invulling aan geeft (D 43). Vanaf maart wordt $\mathrm{H}$ artslag Limburg inderdaad opgenomen als wettelijk verplicht product in het concept 'Productenboek 2004' van de G GD. H iermee is een eerste stap in het verankeringsproces gezet. $D$ e te nemen vervolgstappen zijn: opname van het product in de gemeentelijke (concept)nota's, accordering van die nota's door de gemeenten en accordering van het GGD -Productenboek door $D B$ en $A B$. Wat opvalt aan deze procedure is dat pas in de laatste fase doelen en producten gekoppeld worden aan de beschikbare financiering (!).

O m het draagvlak te vergroten stuurt de G GD eind maart een voortgangsrapportage over $\mathrm{H}$ artslag Limburg naar alle betrokkenen (D 53, D 54). H et rapport laat zien dat het project door de jaren volgens plan is verlopen, dat er samen met derden veel activiteiten zijn gerealiseerd met een goede waardering door de deelnemers, en dat er bij een tussenmeting in 2001 een klein effect op populatieniveau is gevonden (een significante daling in de vetconsumptie onder de jongere helft van respondenten ( $<49$ jaar) ten opzichte van controle regio (Ronda, 2004). 0 p 10 april is er een mini-conferentie in samenwerking met de eindredacteur van de VT V-2002 van het RIV M . O m het draagvlak onder bestuurders en raadsleden verder te vergroten neemt de GGD het initiatief om de resultaten van $\mathrm{H}$ artslag Limburg in alle raadscommissies te presenteren; ter voorbereiding van deze presentaties wordt met ambtenaren en portefeuillehou- 
ders overlegd. Illustratief voor het draagvlak zijn de volgende uitspraken van een portefeuillehouder: "D e aanpak is nog helemaal niet bewezen effectief. Wel kijken we er positief tegenaan vanwege de brede participatie op lokaal niveau. $M$ aar ja, continuering is wel afhankelijk van nadere prioritering binnen de nieuwe nota." (D 41). D e GGD polst daarom de mogelijkheid van alternatieve financieringsbronnen, bijvoorbeeld uit de zgn. landelijke Breedtesportimpuls. $M$ aar dit blijkt niet haalbaar vanwege de lopende belangenstrijd tussen lokale sportclubs en de gemeente (D 41, D 87, D 96). Een andere barrière betreft de wens van alle gemeenten om specifiek de resultaten van de eigen gemeente te vernemen ( $D$ 53; zie ook 6.4.5). D eze wens is slecht verenigbaar met de opzet van de wetenschappelijke effectmeting (te kleine schaalgrootte), maar de GGD spant zich in om zoveel mogelijk gegevens over concrete activiteiten per gemeente uit te splitsen. D e resultaten van deze inspanning worden in de raadscommissies gepresenteerd, evenals tijdens een regionale miniconferentie op de GGD die op 10 april wordt gehouden (D 57). O p deze bijeenkomst is het RIVM aanwezig om de boodschap kracht bij te zetten.

D e ingezette veranderacties vanuit GGD richting gemeenten resulteren in de loop van het voorjaar in de opname van $\mathrm{H}$ artslag Limburg in de conceptnota van de gemeente $M$ aastricht (D 50). D eze nota staat tevens model voor de nota's van de andere gemeenten. 0 p 25 juni wordt de M aastrichtse nota goedgekeurd, waarmee geaccordeerd is dat $\mathrm{H}$ artslag L imburg ondergebracht dient te worden in de reguliere taken van de GGD (D 61). Zoals gezegd: in dit besluit is géén financiële paragraaf opgenomen.

In het azM doorlopen de veranderacties een analoog traject: vanaf maart wordt er door medewerkers van GGD, azM en UM een beleidsnota gemaakt. $0 p 22$ mei wordt dit beleidsplan in het azM gepresenteerd en verkrijgt de steun van de cardiologen (D 66). Vervolgens wordt dit plan tot onderdeel gemaakt van een veelomvattender plan voor oprichting van een nieuw $\mathrm{H}$ artVaatC entrum, en wordt cofinanciering aangevraagd bij het O GZ fonds. D e oorspronkelijk $\mathrm{H}$ artslag-aanpak wordt aangepast aan de nieuwe context ("reïnvented", $\mathrm{H}$ arting, 2005a, 2005b). Resultaat begin juli is een breed gedragen visie, passend bij een van de belangrijkste beleidsprioriteiten van het azM , plus een werkgroep waarin ook de Interne G eneeskunde en de Vaatchirurgie participeren (D 81). Een stap vooruit in de richting van verankering.

M edio 2003 vindt de eerste ronde met interviews en enquêtes plaats. Triangulatie met deze databronnen levert het volgende beeld op dat respondenten hebben van veranderacties van de GGD (zie ook tabel $8.1 \mathrm{t} / \mathrm{m} \mathrm{8.3)}$.

$0 p$ een enkeling na zijn is het merendeel van bestuurders en overige respondenten positief over de inhoud en de vorm van de door de GGD aangereikte informatie. 
$>$ "Ik vind dat zij het werk en het project in algemene goed promoten op alle manieren, en ons ook heel erg ons meenemen in de promoting, dat doen ze heel erg goed, daar ben ik heel lovend over." (81;17.09.2003)

\begin{tabular}{|l|l|l|}
\hline Beïnvloedingsstrategieën: communicatie & \multicolumn{2}{l|}{2003} \\
\hline Item uit vragenlijst & Percentage 'ja' & totaal (n) \\
\hline Informatie over Hartslag Limburg heb ik gekregen via & & \\
de volgende kanalen: & & \\
\hline - voorlichtingsmateriaal van Hartslag Limburg & 65 & $100(78)$ \\
- Hartslag Limburg Nieuwsbrief & 63 & $100(78)$ \\
- de krant (regionaal, wijkkrant of landelijk dagblad) & 55 & $100(78)$ \\
- informatie vanuit de GGD & 54 & $100(78)$ \\
- persoonlijke contacten en overleggen & 51 & $100(78)$ \\
- informatie vanuit de eigen gemeente & 36 & $100(78)$ \\
- via radio of TV & 35 & $100(78)$ \\
- via mondelinge presentatie voor de raadscommissie & 26 & $100(78)$ \\
- ik heb geen informatie over Hartslag Limburg gezien & 0 & $100(78)$ \\
\hline
\end{tabular}

Tabel 8.1 Verandermanagement: factor beïnvloedingsstrategieën; bereik van communicatiemiddelen (percentages van het totaal), in 2003. 


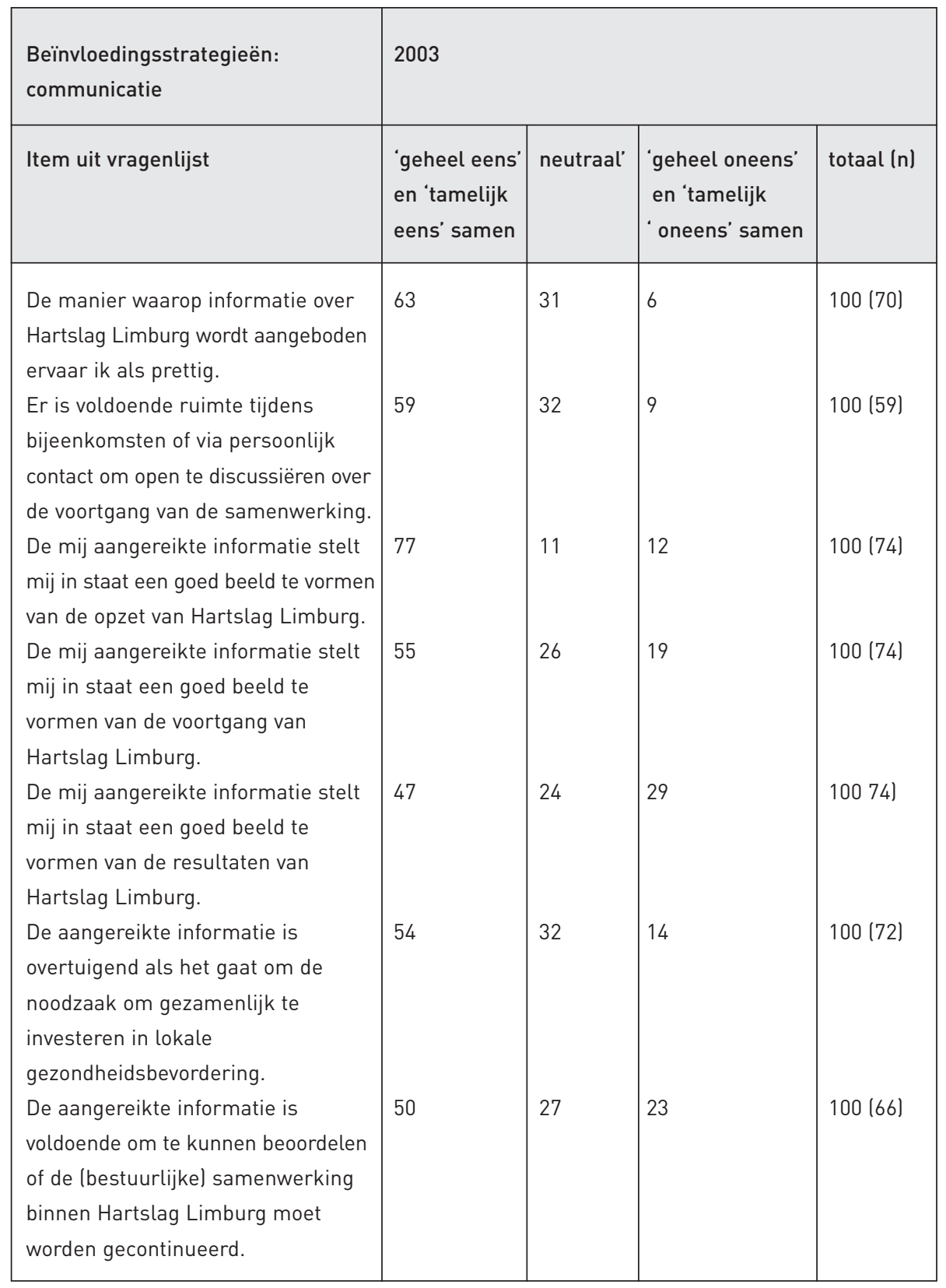

Tabel 8.2 Verandermanagement: factor beïnvloedingsstrategieën, oordeel over communicatie (percentages van het totaal) in 2003. 


\begin{tabular}{|c|c|c|c|c|}
\hline \multirow{2}{*}{$\begin{array}{l}\text { Beïnvloedingsstrategieën: info } \\
\text { over doelbereiking }\end{array}$} & \multicolumn{4}{|l|}{2003} \\
\hline & 'eens' & 'oneens' & 'geen mening' & totaal (n) \\
\hline $\begin{array}{l}\text { Hartslag Limburg heeft een duidelijk } \\
\text { herkenbare plaats verworven bij het } \\
\text { algemene publiek. }\end{array}$ & 62 & 18 & 19 & $100(77)$ \\
\hline $\begin{array}{l}\text { Door Hartslag Limburg zijn meer } \\
\text { organisaties een eigen bijdrage gaan } \\
\text { leveren aan gezondheidsbevorderende } \\
\text { activiteiten. }\end{array}$ & 59 & 5 & 36 & $100(78)$ \\
\hline $\begin{array}{l}\text { Hartslag Limburg heeft door een groot } \\
\text { aantal activiteiten inhoud gegeven aan } \\
\text { het bevorderen van 'gezond leven' in } \\
\text { onze regio. }\end{array}$ & 80 & 8 & 12 & $100(78)$ \\
\hline $\begin{array}{l}\text { Hartslag Limburg draagt merkbaar bij } \\
\text { aan een betere samenwerking op het } \\
\text { terrein van gezondheidsbevordering. }\end{array}$ & 58 & 11 & 31 & $100(78)$ \\
\hline $\begin{array}{l}\text { Door Hartslag Limburg is het onderwerp } \\
\text { 'gezondheidsbevordering' hoger op de } \\
\text { politieke agenda van mijn gemeente } \\
\text { gekomen. }\end{array}$ & 50 & 16 & 34 & $100(78)$ \\
\hline Meer mensen zijn gezonder gaan leven. & 39 & 19 & 43 & $100(78)$ \\
\hline
\end{tabular}

Tabel 8.3 Verandermanagement: factor beïnvloedingsstrategieën, oordeel over doelbereiking (percentages van het totaal), in 2003.

Tabel 8.1 laat zien dat informatie via vele kanalen is ontvangen, waarbij zowel voorlichtingsmateriaal als de $\mathrm{H}$ artslag Limburg $\mathrm{N}$ ieuwsbrief door ruim $60 \%$ van de respondenten aangehaald worden. G een van de respondenten blijkt niet geïnformeerd. D e aangeboden informatie wordt merendeels als 'prettig' ervaren, ruim driekwart vindt de informatie een goed beeld geven van de opzet van $\mathrm{H}$ artslag Limburg (tabel 8.2). Wat betreft de overtuigingskracht van de aangereikte informatie ten aanzien van resultaten, de noodzaak om gezamenlijk te investeren en de samenwerking te continueren (tabel 8.2), geeft ongeveer de helft een positieve reactie, een kwart is neutraal en een kwart is negatief. $D$ it duidt op een nog kwetsbaar draagvlak. Tabel 8.3 laat vervolgens zien dat de meningen over de doelbereiking nog tamelijk verdeeld zijn. H oewel een ruime meerderheid positief is over de ontplooide activiteiten, blijkt slechts de helft van de respon- 
denten van mening dat het onderwerp hoger op de politieke agenda is gekomen. Verder valt op dat er in 2003 kritisch wordt gedacht over welke informatie nodig is om het bestuurlijk draagvlak te vergroten. Enkele bestuurders uiten in de interviews dat er behoefte is aan "meer zichtbare resultaten en inbedding in landelijk beleid", anderen realiseren zich dat zij daar ook zelf een rol in hebben.

$>$ "Het zou beter uitgelegd moeten worden en tijdig. De politiek beslist, maar nu met het duale stelsel ligt de verantwoording toch meer bij raadscommissies, dat zou ik doen. Ik denk dus vooral de commissies en de portefeuillehouder is degene die verantwoordelijk voor het feit dat het in het college aandacht krijgt." $(43 ; 27.08 .2003)$

Tegelijkertijd signaleren de meeste bestuurders dat voor het voor hen belangrijk is dat "gezien het tijdsbeeld met de financiën" de kosten omlaag gebracht kunnen worden. De GGD komt hieraan (deels) tegemoet in de vorm van verschillende 'goedkopere' versies van het product $\mathrm{H}$ artslag Limburg (later Lokale Gezondheidsbevordering genoemd, zie tabel 4.1, paragraaf 4.2) in het concept Productenboek 2004.

U it zowel interviews als enquête blijkt dat men meer zicht wil op wat $\mathrm{H}$ artslag Limburg qua resultaten feitelijk oplevert (tabel 8.2 en 8.3). Sommigen zijn tevreden over de tussentijdse procesresultaten (brede participatie, wetenschappelijke basis, opgebouwde samenwerkingsstructuur), anderen betwijfelen of de moeilijkste doelgroepen daadwerkelijk bereikt worden en of dit wel gezondheidswinst zal opleveren. O p dit laatste punt kan de GGD niet anders dan melden dat er in de tussenmeting van 2001 een klein effectje gevonden is en dat verdere effectresultaten pas in de loop van 2004 verwacht worden (D 54, D 75).

Samenvattend is het beeld dat de veranderacties in de eerste helft van 2003 redelijk adequaat waren, maar dat daarmee nog niet gezegd is dat het draagvlak voldoende versterkt is. In het proces naar verankering zijn concrete stappen bereikt, bij zowel gemeenten als in het ziekenhuis. $\mathrm{H}$ et draagvlak lijkt positief voor zowel het community-deel als het hoogrisico-deel in het azM , mits de financiering voor gemeenten (en azM) haalbaar blijft en de te verwachten effectresultaten niet teleurstellend blijken. In hoofdstuk 10 komen deze nuances in draagvlak uitgebreid aan bod. 


\subsubsection{De belangrijkste veranderacties in tweede helft 2003}

D e tweede helft van 2003 is een cruciale periode (zie paragraaf 4.3.3). Tekenend hiervoor is ook het relatief grote aantal negatieve gebeurtenissen in de feitenbeschrijving over deze periode.

Terwijl begin juli een $\mathrm{N}$ ieuwsbrief over $\mathrm{H}$ artslag Limburg breed verspreidt wordt, dringt bij de GGD het besef door dat het ontbreekt aan capaciteit om zowel het gemeentelijke deel als het eerste en tweedelijns deel van $\mathrm{H}$ artslag Limburg in de lucht te houden. Besloten wordt om het huisartsendeel te laten vallen.

Begin juli is de gemeente $M$ aastricht al bezig met de aankomende G SB-bezuiniging, zoals beschreven in paragraaf 4.3.3. $\mathrm{H}$ et is curieus te noemen dat hierover met de GGD amper wordt gecommuniceerd; mogelijk is de GGD zelfs foutief geïnformeerd. In elk geval luidt het emailbericht van 4 juli aan het management: " $\mathrm{H}$ artslag moet ingebed worden in het reguliere beleid. $\mathrm{H}$ et budget dat het welzijnswerk van de gemeente krijgt voor $\mathrm{H}$ artslag zijnde $€ 91.000$ wordt naar de GGD gesluisd" (D 79). De GGD checkt de informatie niet, en onderneemt dus ook geen directe actie. M ogelijk speelde eerdere toezeggingen om de GGD te ontzien hierin mee. Pas op 2 oktober dringt de werkelijkheid van een harde bezuiniging tot de GGD door (plus de argumentatie dat 'projecten' niet onder die eerdere toezegging vallen). Achteraf waarschijnlijk een gemiste kans om in een vroege fase de gemeente $M$ aastricht al snog te overtuigen van de nadelen van de voorgenomen bezuiniging. Zoals blijkt uit de verdere procesbeschrijving kan de opgelegde bezuiniging later niet meer teruggedraaid worden. $M$ instens even curieus is dat op 11 juli de portefeuillehouder van $M$ aastricht in het D B meldt dat de gemeente "minder geld beschikbaar zal hebben voor de GGD als geheel". Later blijkt dat het hier gaat om 91 mille GSB-subsidie voor het welzijnswerk plus 70 mille voor de GGD, kortingen vanwege "eindigheid van projecten" en dus niet vallend onder eerdere toezeggingen om het GGD budget te ontzien. Volgens de notulen wordt er in dit D B met geen woord gesproken over de voorgenomen GSB-bezuiniging, noch over de precieze omvang van de dreigende bezuiniging die op 9 juli in de gecombineerde raadscommissie Algemene Zaken/M iddelen zijn behandeld (D 78). De GGD directeur pleit voor "regelmatig en structureel overleg" en de portefeuillehouder van M aastricht zegt toe "de beslissing nogmaals te bezien" (D 82). Echter, zoals toegelicht in paragraaf 6.4.4 blijkt uit data (notulen, interview) dat er bij de portefeuillehouder een visie bestaat die strijdig is met de afgesproken uitgangsprincipes van $\mathrm{H}$ artslag Limburg. D e portefeuillehouder ziet een "dubbeling" (dus rijp voor bezuiniging) waar de $\mathrm{H}$ artslagpartners feitelijk al jaren een complementaire samenwerking hebben. Geconstateerd moet worden dat GGD en gemeente onvoldoende met elkaar hebben gecommuniceerd over dit verschil in visie dat de basis vormt voor de bezuiniging die een cruciale impact had. 
Waarschijnlijk heeft hierbij meegespeeld dat bij de omzetting van $\mathrm{H}$ artslag Limburg van project naar regulier GGD-product geruisloos ook de functie van de Stuurgroep (zie 2.5) verviel. De 'nieuwe' wethouders zagen dit als een overbodige structuur, maar hiermee verviel een directe invloed van de partners azM , U M en welzijnswerk op de verankering. $H$ ier is dus sprake van een door de GGD gemiste kans om een nieuwe vorm te vinden voor 'coalition building'. D oor het missen van die kans kwam de hele verantwoordelijkheid voor pleitbezorging te liggen bij één persoon: de GGD -directeur.

Een volgende kritische noot over de veranderacties vanuit de GGD betreft besluiten van de GGD directeur op 2 en 10 oktober om geen signaal over de bezuiniging af te geven, geen gezamenlijke actie met de $\mathrm{H}$ artslagpartners te organiseren en geen (reguliere) nieuwsbrief uit te brengen. 0 ok de toezeggingen van $M$ aastricht van 11 juli in het D B dat "er tussentijdse evaluaties gedaan worden, op basis waarvan besloten kan worden deze projecten al dan niet te continueren", en de uitspraak "de beslissing nogmaals te bezien" worden door de directeur niet aangegrepen om actie te ondernemen. Althans niet in een vorm die in de data is terug te vinden. De verklaring hiervoor is simpel: de directeur acht de relatie met de gemeente $M$ aastricht te gespannen vanwege een tweetal belangrijkere dossiers: de fusie en de nieuwe tariefstructuur (D 97)(zie 6.3.3., resp. 6.3.1). U it triangulatie met interviews blijkt dat het uitblijven van publiciteit in periode tot april 2004 door enkele bestuurders wordt gekwalificeerd als "karig". K ritiek op de rol van de GGD is er verder nog van twee kanten: één van de portefeuillehouders meent dat de inbedding van $\mathrm{H}$ artslag Limburg in het reguliere G GD -beleid te laat opgang gekomen is (D 101), en de Inspectie schrijft ten aanzien van "de uitzonderlijk goed ontwikkelde GVO -functie" dat het een "taak is voor de GGD om de bestuurders op een politiek sensitieve manier duidelijk te maken wat het belang is van de activiteiten van de GGD." (D 114). Inhoudelijk positief is de veranderactie van de GGD op 15 oktober om speciaal voor bestuursleden en raadsleden het definitieve concept Productenboek 2004 te presenteren. In de presentaties van directeur en projectleider wordt uitgebreid ingegaan op de motivatie voor het product $H$ artslag Limburg. G oedkeuring van de bijbehorende begroting staat echter gepland voor december, en er gaapt nog altijd een gat tussen wat de GGD vraagt en wat gemeenten bereid zijn te geven. $N$ iettemin lijkt de veranderactie redelijk adequaat, en lijkt er draagvlak voor de positionering in het verplichte deel van het productenboek. Een portefeuillehouder: "H artslag Limburg moet gewoon doorgaan. D e inhoud is prima." (D 101). Of dat draagvlak er op dat moment echt is blijft echter twijfelachtig, getuige het D B-besluit van 11 december (zie onder) en kritiek die ruim een half jaar later nog doorklinkt in interviews. 
$>$ Ja, daar over gaat de discussie, of het verwijt denk ik van sommigen naar de GGD toe, van kijk, gaat het niet linksom dan probeert men het rechtsom. Krijgen we het niet als project gefinancierd dan gaat men het inbrengen in het productenboek en proberen ze het via die weg om het project boven water te houden. Maar van de andere kant, zit er sowieso druk op de begroting, dus in feite blijft dit onderdeel toch om een of andere reden altijd een punt van discussie.

(55;28.07.2004)

O p 28 november worden er op aandringen van de projectleider alsnog twee brandbrieven verstuurd (één vanuit de GGD en één vanuit partners van UM en azM ). $H$ et resultaat van deze veranderactie is dat op 11 december het $D B$ besluit tot het instellen van een werkgroep die de bezuinigingen rond $\mathrm{H}$ artslag Limburg in kaart moet brengen. 0 pvallend echter is de uitspraak van de GGD directeur de week ervoor "dat de wethouder M aastricht niet terug zal willen komen op de gemeentelijke begroting die half oktober door de Raad is vastgesteld. O plossingen kunnen alleen nog binnen dat kader gezocht worden." (D 121) Relevant in dit kader is dat deze wethouder tegelijkertijd een zeer gespannen relatie met de gemeenteraad heeft op meerdere dossiers: de wethouder kan zich inmiddels geen misstap meer veroorloven (zie 6.2.1).

Samenvattend kan gezegd worden dat de veranderacties van de GGD in de tweede helft van 2003 inadequaat waren gegeven de context van een (per definitie) ondoorzichtig gemeentelijk en intergemeentelijk besluitvormingstraject. Zo kon het dat de volgende elementen gemist of onderschat werden. D e M aastrichtse nota bestaat uit doelen zonder financieringsparagraaf, de wethouder ontwikkelt zelfstandig een afwijkende visie waarover niet wordt gediscussieerd, er loopt een parallel bezuinigingstraject waarover de gemeente $M$ aastricht de GGD inadequaat informeert (zie 6.4.3), en dat traject heeft tevens impact op de belangrijkste uitvoerende samenwerkingspartner (welzijnswerk) (zie 6.4.4). D e GGD mist de kans om de Stuurgroep om te vormen en de directeur kiest er bewust voor om geen actie samen met partnerorganisaties te ondernemen. $\mathrm{H}$ et feit dat bijvoorbeeld het welzijnswerk, anders dan de GGD , een zelfstandig bestuur had (dus niet direct door een wethouder aangestuurd), maakt het in de ogen van de GGD -directeur ongepast om gezamenlijk actie te ondernemen tegen de gemeentelijke bezuinigingen.

In dit moeilijke besluitvormingstraject hoopt de GGD gemeentelijke financiering van $\mathrm{H}$ artslag Limburg al snog rond te krijgen op grond van opname van het product in het verplichte 'basispakket'. Triangulatie laat zien dat sommige bestuurders dit zien als een truc. D e uitkomst wordt dat gemeenten het verplichte 
karakter wel accepteren, maar de bijbehorende begroting niet. $D$ at knelpunt wordt in eerste instantie als een opdracht teruggelegd bij de GGD: die moet het product realiseren ondanks de opgelegde bezuiniging. D e GGD directeur accepteert dit in eerste instantie, onder verwijzing naar de M aastrichtse begroting die half oktober door de gemeenteraad is vastgesteld. $\mathrm{H}$ et centrale beeld is dat de GGD kansen voor coalition building en leiderschap laat liggen.

\subsubsection{De belangrijkste veranderacties in 2004}

In 2004 zijn in totaal 23 gebeurtenissen gescoord, waarvan 18 positief en 5 negatief. $\mathrm{H}$ et overgrote deel van de scores betreft het eerste half jaar.

Een belangrijke actie betreft het bijeenkomen begin januari van de werkgroep die de bezuinigingen (van $\mathrm{M}$ aastricht en inmiddels ook Valkenburg, totaal inmiddels 180 mille) moet inventariseren en moet zoeken naar oplossingen (D 127). De GGD stelt een compromis voor waarin 65 van 160 mille aan M aastrichtse bezuiniging opgevangen wordt. D e gemeenten zijn in de werkgroep vertegenwoordigd door de ambtenaren volksgezondheid; zij zeggen toe intern te zullen zoeken naar middelen om het gat te overbruggen. D eze ambtenaren vormen echter het laagste niveau in de ambtelijke hiërarchie. $\mathrm{H}$ et mag dus niet verbazen dat zij een maand later rapporteren geen middelen gevonden te hebben. $\mathrm{N} \mathrm{u}$ onderneemt de GGD -directeur zelf actie, en spreekt af met de wethouder dat er op 1 april opnieuw overlegt wordt. Inzet van directeur en ambtenaar is om voor de begroting 2005 als eerste het product $\mathrm{H}$ artslag Limburg te regelen (D 136, D 145). Zonder opgaaf van redenen blaast de wethouder dit initiatief op 16 maart af. D e GGD schikt zich (D 146). Een intern verslag vermeldt dat de inzet van de directeur is stukgelopen op de houding van ambtenaar en portefeuillehouder van $\mathrm{M}$ aastricht, mede in het licht dat de gesprekken over de begroting van 2005 bijzonder moeilijk verlopen (D 151).

Tegelijkertijd doet de GGD haar best om het draagvlak in de andere gemeenten overeind te houden. $\mathrm{M}$ et name in $\mathrm{M}$ argraten komt $\mathrm{H}$ artslag Limburg meerdere keren op de agenda van de raadscommissie: raadsleden willen veel gedetailleerdere informatie over activiteiten, kosten, deelnemers en effecten, en met name het CD A is zeer kritisch over de inschaling als verplichte basistaak (D 67, D 73, D 143, D 149, D 158, D 163, D 165, D 169). D ie informatie wordt in nauwe samenwerking tussen GGD en ambtenaren geleverd, maar wat minstens zo belangrijk blijkt, is dat de begroting anders wordt opgezet. H et accent komt te liggen op de feitelijke uitvoerende activiteiten in de eigen gemeente, in plaats van uren en een ongedifferentieerd activiteitenbudget voor de GGD. Op aandringen van de wethouder krijgt de GGD nog eens extra spreektijd voor de raadscommissie. En dit keer is de timing bijzonder goed: de commissie vergadert op 21 
april, net een week na publicatie van gunstige effectcijfers op de voorpagina van de Volkskrant.

D eze publicatie is mogelijk gemaakt door een actief ontwikkelde relatie tussen de projectleider van $\mathrm{H}$ artslag Limburg en een redacteur van de krant naar aanleiding van eerdere berichtgevingen. D e veranderactie betrof hier het 'managen' van de berichtgeving: de resultaten worden voor het eerst gepresenteerd op het $\mathrm{N}$ ationale $\mathrm{C}$ ongres Volksgezondheid, en de primeur wordt gegund aan de Volkskrant, in de wetenschap dat deze timing maximale invloed zal hebben op zowel congresgangers als op de Limburgse pers en de lokale bestuurders (D 157, D 159). In de commissievergadering in $\mathrm{M}$ argraten van 21 april worden alle ingezette veranderacties uiteindelijk beloond. $\mathrm{N}$ a een felle discussie verwoordt het CD A alsnog overtuigd te zijn door de aangeleverde informatie en de commissie accordeert de nota lokaal gezondheidsbeleid 2003-2007, inclusief het volledige voor $\mathrm{H}$ artslag Limburg gevraagde bedrag.

0 ok in andere gemeenten heeft de publicatie van effectresultaten een impact, echter het belang ervan wordt door portefeuillehouders deels pas later erkend.

$>$ En daar vind ik dat we met het nieuwe lokale gezondheidsbeleid, dat we zouden moeten formuleren: wat is dan nu nodig aan inzet van onze middelen. Zodat ik straks kan zeggen: in 2004 waren we hier in situatie nul en in 2008 zijn we in situatie één. Nou, ik vind wel dat we vele malen meer die kant op moeten gaan en er is één elementje die bewezen heeft dat ook te kunnen en dat is Hartslag Limburg geweest. Die hebben gezegd: dit is de nulsituatie, en na vijf jaar kwamen ook de eerste resultaten." (81;15.07.2004)

D e volgende uitdaging voor de GGD in 2004 ligt nu in de scheve verdeling van gemeentelijke bijdragen, geformuleerd in een brief van de gemeente Eijsden aan het DB van de GGD: “... het kan niet zo zijn dat M eerssen en Eijsden buitenproportioneel gaan bijdragen" (zie 6.4.5). Eind april 2004 zijn M eerssen, Eijsden en $\mathrm{M}$ argraten bereid $\mathrm{H}$ artslag Limburg te financieren, maar zij vormen een relatieve minderheid. H oewel het de GGD lukt om een product Lokale Gezondheidsbevordering opgenomen te krijgen in de fusieplannen, slepen de onderhandelingen over de begroting 2005 zich moeizaam voort. M edio juli wordt de reden hiervan duidelijk: er blijken nog veel meer financiële knelpunten, in totaal oplopend tot een tekort van acht ton euro. O ok al is een deel van dit tekort te wijten aan eerder beleid van de gemeenten (verbod op reserve opbouw, risico markttaken, gebrekkig zicht op consequenties innovatieve projecten; zie 6.3), toch kiezen de bestuurders ervoor om geen extra middelen beschikbaar te stelIen. D it blijkt uit de notulen over de fusie (zie 6.3.3): “D e kosten hoopt men 
via inverdieneffecten te verhalen. $\mathrm{H}$ et is niet de bedoeling de lopende begrotingen van de fuserende partners te belasten. (..) $\mathrm{H}$ et budget van de nieuwe organisatie mag niet meer bedragen dan de som van de budgetten van de fuserende partners" (D 178).

$H$ et verandermanagement van de GGD bestaat vervolgens uit niet veel anders dan zich te schikken. D e kerntaken JGZ en infectieziektebestrijding moeten overeind blijven, dus binnen de GVO moeten de klappen worden opgevangen. $\mathrm{H}$ oe hoog de nood is blijkt uit notulen van het D B:

$>$ Alle saneringsvoorstellen worden op maximale haalbaarheid besproken. Een lange rij van per acuut in te voeren maatregelen wordt aanbevolen, waaronder de maatregel dat "alle offertes of rekeningen boven de 100 euro aan de directeur voorgelegd dienen te worden. (..) De directeur merkt op dat de meeste aanbevelingen al aan de orde zijn." (D180)

Als uiteindelijk geen extra middelen beschikbaar komen wordt het knelpunt doorgesluisd naar het cluster gezondheidsbevordering. $\mathrm{H}$ oewel het $\mathrm{DB}$ aangeeft dat "met het traject van versobering de wettelijke eisen ten aanzien van JGZ, GVO en infectieziektebestrijding (IB) niet in gevaar mogen komen" (D 178), vindt er binnen het M T van de GGD geen principiële discussie plaats over de verdeling van de lasten tussen de drie prioriteiten. $\mathrm{H}$ ierin kan meegespeeld hebben dat voor de JGZ en de IB de wettelijke eisen veel gedetailleerder vastliggen dan voor de GVO. Resultante is dat het cluster gezondheidsbevordering zelf haar problemen moet oplossen en geen enkele vrijkomende vacature wordt nog ingevuld. Zo wordt voor nog eens bijna een ton euro bezuinigd.

Achteraf kijkend naar dit proces valt op dat in de fase waarin binnen de GGD moeilijke keuzes gemaakt moeten worden, er niets terug te vinden is dat duidt op een gerichte sturing op ' $G$ VO '-doelen, tussenstappen en inzet van eigen autoriteit (zie definitie leiderschap, paragraaf 7.5) vanuit de directie. $D$ at het cluster gezondheidsbevordering zelf alle financiële tekorten moet oplossen duidt op een proces dat verloopt in de richting van de minste weerstand. Beoordeeld vanuit de optiek van leiderschap betekent dit wel een tekortschietend leiderschap.

Resultante wordt het ineenschuiven van $\mathrm{H}$ artslag Limburg en andere onderdelen tot een sober product Lokale G ezondheids-bevordering waarin het oorspronkelijke $\mathrm{H}$ artslag Limburg ongeveer gehalveerd is (zie 4.2). Enkele bestuurders ventileren hierover enige (zelf)kritiek: 
$>$ "Wat ik me dus nu ook realiseer is dat wij over dit soort ontwikkelingen ook te weinig communiceren met verantwoordelijke bestuurders en dat zou wellicht nog eens een uitdaging voor de toekomst zijn. (...) In zijn directe relatie, ook gezien de grote van de bedragen, is Hartslag Limburg eigenlijk dubbel gepakt." $(81 ; 15.07 .2004)$

M edio 2004 vindt de tweede ronde met interviews en enquêtes plaats. Triangulatie met deze databronnen levert aanvullend aan het bovenstaande een wisselend beeld op dat respondenten hebben van veranderacties van de GGD over de periode medio 2003 tot medio 2004.

U it de analyse van de enquête van 2004 komt naar voren dat het beeld ten opzichte van 2003 nauwelijks gewijzigd is (tabel $8.4 \mathrm{t} / \mathrm{m} \mathrm{8.6)}$ ). H et percentage respondenten dat het eens is met de uitspraak 'dat meer mensen gezonder zijn gaan leven' is gestegen van 39 naar $58 \%$, en het percentage dat vindt dat het onderwerp hoger op gemeentelijke agenda is gekomen stijgt van 50 naar $67 \%$ (tabel 8.6). Voor het overige blijkt het meningenlandschap nagenoeg onveranderd. $D$ it is opvallend te noemen, want slechts enkele maanden ervoor zijn de positieve cijfers van het RIVM bekend geworden. Geconcludeerd moet worden dat deze effectresultaten kennelijk een beperkte impact hadden bij de respondenten.

Aanvullend komt uit interviews met bestuurders naar voren dat de door de GGD aangereikte informatie wordt beoordeeld van uitgesproken positief ( $M$ argraten) tot 'karig'. Bij deze laatste uitspraak wordt gerefereerd aan het uitblijven van nieuwsbrieven over de periode medio 2003 tot april 2004. O ok klinkt een deel van oude ressentimenten door: enkele bestuurders voelen zich voor het blok gezet ("zo was het nooit bedoeld, een project is eindig") of geven aan dat ze de gepresenteerde effectresultaten weinig overtuigend vinden ("D it heeft met GVO te maken, en dat is dus één van de meest vage aspecten van de GGD.") Tot slot is ook nog steeds kritiek van sommigen op het positioneren door de GGD van $\mathrm{H}$ artslag Limburg binnen het basispakket ("Gaat het niet linksom dan probeert men het rechtsom."). 


\begin{tabular}{|c|c|c|c|c|}
\hline Beïnvloedingsstrategieën: communicatie & \multicolumn{2}{|l|}{2003} & \multicolumn{2}{|l|}{2004} \\
\hline Item uit vragenlijst & $\begin{array}{l}\text { Percentage } \\
\text { 'ja' }\end{array}$ & $\begin{array}{l}\text { totaal } \\
\text { (n) }\end{array}$ & $\begin{array}{l}\text { Percentage } \\
\text { 'ja' }\end{array}$ & $\begin{array}{l}\text { totaal } \\
\text { (n) }\end{array}$ \\
\hline $\begin{array}{l}\text { Informatie over Hartslag Limburg heb ik } \\
\text { gekregen via de volgende kanalen: }\end{array}$ & & & & \\
\hline $\begin{array}{l}\text { - voorlichtingsmateriaal van Hartslag } \\
\text { Limburg }\end{array}$ & 65 & $100(78)$ & 54 & $100(52)$ \\
\hline - Hartslag Limburg Nieuwsbrief & 63 & $100(78)$ & 75 & $100(52)$ \\
\hline $\begin{array}{l}\text { - de krant (regionaal, wijkkrant of } \\
\text { landelijk dagblad) }\end{array}$ & 55 & $100(78)$ & 60 & $100(52)$ \\
\hline - informatie vanuit de GGD & 54 & $100(78)$ & 46 & $100(52)$ \\
\hline - persoonlijke contacten en overleggen & 51 & $100(78)$ & 54 & $100(52)$ \\
\hline - informatie vanuit de eigen gemeente & 36 & $100(78)$ & 42 & $100(52)$ \\
\hline - via radio of TV & 35 & $100(78)$ & 21 & $100(52)$ \\
\hline $\begin{array}{l}\text { - via mondelinge presentatie voor de } \\
\text { raadscommissie }\end{array}$ & 26 & $100(78)$ & 35 & 100 (52) \\
\hline $\begin{array}{l}\text { - ik heb geen informatie over Hartslag } \\
\text { Limburg gezien }\end{array}$ & 0 & $100(78)$ & 0 & $100(51)$ \\
\hline
\end{tabular}

Tabel 8.4 Verandermanagement: factor beïnvloedingsstrategieën; bereik van communicatiemiddelen (percentages van het totaal), in 2003 en 2004. 
Beïnvloedingsstrategieën: communicatie

\begin{tabular}{|c|c|c|c|c|c|c|c|c|}
\hline \multirow[t]{2}{*}{ Item uit vragenlijst } & \multicolumn{2}{|c|}{$\begin{array}{l}\text { 'geheel eens' } \\
\text { en 'tamelijk } \\
\text { eens' }\end{array}$} & \multicolumn{2}{|c|}{ 'neutraal' } & \multicolumn{2}{|c|}{$\begin{array}{l}\text { 'geheel oneens' } \\
\text { en 'tamelijk } \\
\text { oneens' }\end{array}$} & \multicolumn{2}{|l|}{ totaal (n) } \\
\hline & 2003 & 2004 & 2003 & 2004 & 2003 & 2004 & 2003 & 2004 \\
\hline $\begin{array}{l}\text { De manier waarop informatie over Hartslag Limburg } \\
\text { wordt aangeboden ervaar ik als prettig. }\end{array}$ & 63 & 71 & 31 & 28 & 6 & 2 & $100(70)$ & $100(51)$ \\
\hline $\begin{array}{l}\text { Er is voldoende ruimte tijdens bijeenkomsten of via } \\
\text { persoonlijk contact om open te discussiëren over } \\
\text { de voortgang van de samenwerking. }\end{array}$ & 59 & 59 & 32 & 30 & 9 & 11 & 100 (59) & $100(44)$ \\
\hline $\begin{array}{l}\text { De mij aangereikte informatie stelt mij in staat een goed } \\
\text { beeld te vormen van de opzet van Hartslag Limburg. }\end{array}$ & 77 & 67 & 11 & 19 & 12 & 13 & $100(74)$ & $100(52)$ \\
\hline $\begin{array}{l}\text { De mij aangereikte informatie stelt mij in staat een goed } \\
\text { beeld te vormen van de voortgang van Hartslag Limburg. }\end{array}$ & 55 & 52 & 26 & 32 & 19 & 16 & $100(74)$ & $100(50)$ \\
\hline $\begin{array}{l}\text { De mij aangereikte informatie stelt mij in staat een goed } \\
\text { beeld te vormen van de resultaten van Hartslag Limburg. }\end{array}$ & 47 & 28 & 24 & 28 & 29 & 24 & $100(74)$ & $100(50)$ \\
\hline $\begin{array}{l}\text { De aangereikte informatie is overtuigend als het gaat om } \\
\text { de noodzaak om gezamenlijk te investeren in lokale } \\
\text { gezondheidsbevordering. }\end{array}$ & 54 & 49 & 32 & 32 & 14 & 19 & $100(72)$ & $100(47)$ \\
\hline $\begin{array}{l}\text { De aangereikte informatie is voldoende om te kunnen } \\
\text { beoordelen of de (bestuurlijke) samenwerking binnen } \\
\text { Hartslag Limburg moet worden gecontinueerd. }\end{array}$ & 50 & 44 & 27 & 30 & 23 & 26 & $100(66)$ & $100(43)$ \\
\hline
\end{tabular}

Tabel 8.5 Verandermanagement: factor beïnvloedingsstrategieën, oordeel over communicatie (percentages van het totaal), in 2003 en 2004. 


\begin{tabular}{|c|c|c|c|c|c|c|c|c|}
\hline \multicolumn{9}{|l|}{ Beïnvloedingsstrategieën: info over doelbereiking } \\
\hline \multirow[t]{2}{*}{ Item uit vragenlijst } & \multicolumn{2}{|l|}{ eens } & \multicolumn{2}{|c|}{ oneens } & \multicolumn{2}{|c|}{ geen mening } & \multicolumn{2}{|l|}{ totaal $(n)$} \\
\hline & 2003 & 2004 & 2003 & 2004 & 2003 & 2004 & 2003 & 2004 \\
\hline $\begin{array}{l}\text { Hartslag Limburg heeft een duidelijk herkenbare plaats } \\
\text { verworven bij het algemene publiek. }\end{array}$ & 63 & 64 & 18 & 8 & 19 & 29 & $100(77)$ & $100(52)$ \\
\hline $\begin{array}{l}\text { Door Hartslag Limburg zijn meer organisaties een eigen } \\
\text { bijdrage gaan leveren aan gezondheidsbevorderende } \\
\text { activiteiten. }\end{array}$ & 59 & 67 & 5 & 8 & 36 & 25 & $100(78)$ & $100(52)$ \\
\hline $\begin{array}{l}\text { Hartslag Limburg heeft door een groot aantal activiteiten } \\
\text { inhoud gegeven aan het bevorderen van 'gezond leven' in } \\
\text { onze regio. }\end{array}$ & 80 & 89 & 8 & 4 & 12 & 8 & $100(78)$ & $100(52)$ \\
\hline $\begin{array}{l}\text { Hartslag Limburg draagt merkbaar bij aan een betere } \\
\text { samenwerking op het terrein van gezondheidsbevordering. }\end{array}$ & 58 & 64 & 11 & 10 & 31 & 27 & 100 (78) & $100(52)$ \\
\hline $\begin{array}{l}\text { Door Hartslag Limburg is het onderwerp 'gezondheids- } \\
\text { bevordering' hoger op de politieke agenda van mijn } \\
\text { gemeente gekomen. }\end{array}$ & 50 & 67 & 16 & 10 & 34 & 23 & $100(78)$ & $100(52)$ \\
\hline Meer mensen zijn gezonder gaan leven. & 39 & 58 & 19 & 12 & 43 & 31 & $100(78)$ & $100(52)$ \\
\hline
\end{tabular}

Tabel 8.6 Verandermanagement: factor beïnvloedingsstrategieën, oordeel over doelbereiking (percentages van het totaal), in 2003 en 2004. 
Samenvattend is het beeld over 2004 dat de veranderacties richting M aastricht en Valkenburg weinig opleverden voor zowel de begroting van 2004 als die van 2005. H et door deze gemeenten uitgesproken draagvlak contrasteert met het feit dat zij het nalaten om een hoger niveau ambtenaar te belasten met het zoeken naar oplossingen. Dit teken van een nogal wankel draagvlak past bij het beeld uit de enquête van 2004: de meningen over de veranderacties en de resultaten van $\mathrm{H}$ artslag Limburg zijn ten opzichte van 2003 nagenoeg onveranderd. K rap de helft van de respondenten vindt de informatie voldoende om de resultaten te kunnen beoordelen. D it past bij de conclusie dat inzet van alléén operationeel verandermanagement onvoldoende is.

Tegelijkertijd laat de gang van zaken in de gemeente $M$ argraten wel een succesvol verloop zien. Kenmerkend verschil met $M$ aastricht betreft de randvoorwaarden waarbinnen deze veranderactie verloopt: portefeuillehouder en ambtenaar vervullen beiden een sterke (regie)rol, communiceren beiden open en flexibel met de GGD , weten ondanks de bezuinigingsdruk op creatieve manier de begroting overeind te houden en de timing van het bekend worden van effectresultaten vlak voor het moment van besluitvorming is bijzonder gunstig.

$\mathrm{H}$ et draagvlak en de bereidheid tot financiering van drie kleine gemeenten conflicteert echter met de bezuiniging van $M$ aastricht (en in mindere mate Valkenburg). D e mogelijkheid om hier nog verandering in te brengen vanuit de GGD zijn klein, met name vanwege de fusie.

D e bezuinigingsdruk leidt bij de GGD intern echter niet tot een principiële discussie over prioriteiten in de verhouding JGZ, IB en GVO. Hoewel het D B aangeeft alle drie te vatten onder de wettelijke eisen, neemt de GGD directeur geen initiatief om dit intern te vertalen naar een discussie op M T-niveau. Achteraf alles afwegend tegen de eerder beschreven externe en contextuele factoren moet er begrip opgebracht worden voor de moeilijke omstandigheden waarin geopereerd moest worden. D esalniettemin kan de conclusie niet anders zijn dat leiderschap juist in deze situaties zichtbaar moet worden. D aar is in deze casus onvoldoende van gebleken.

\subsubsection{De belangrijkste veranderacties in 2005}

In 2005 zijn elf gebeurtenissen gescoord. De inzet vanuit de G GD betreft vooral presentaties van resultaten, zowel lokaal als nationaal. Begin april komt de U M met de eerste gunstige uitkomsten van de kosteneffectiviteitanalyse. D eze resultaten worden op 12 april in het AB gepresenteerd (D 197). Bestuurders van M aastricht en Valkenburg geven aan "het jammer te vinden dat nu slechts zo beperkt vorm gegeven wordt aan gezondheidsbevordering". D e fuserende GGD geeft aan vooral werk te willen maken van participatie in het landelijke convenant tussen 
VN G, GGD N ederland en N IGZ om zo alsnog werk te maken van de erfenis van $\mathrm{H}$ artslag Limburg (D 208). Verder wordt de samenwerking gemeente, GGD, en UM nieuw leven ingeblazen via de oprichting van een academische werkplaats public health, waar gezondheidsbevordering een prominente plaats inneemt. De honorering van deze academische werkplaats eind 2005 kan gezien worden als vorm van verankering van de samenwerking vanuit $\mathrm{H}$ artslag Limburg. Een cruciale bevorderende factor is daarbij opnieuw: externe financiering.

\subsection{Discussie en conclusie}

\subsubsection{Betrouwbaarheid van de resultaten}

Kern van de analyse betreft de triangulatie van data uit drie bronnen: feitenbeschrijving, interviews en enquêtes. Van deze drie is de feitenbeschrijving de belangrijkste omdat hier de feitelijke gebeurtenissen in zijn gedocumenteerd.

K ritiek hierop is mogelijk. Er kan sprake zijn van selectiebias, doordat relevante gebeurtenissen gemist kunnen zijn. D it geldt met name voor gebeurtenissen die buiten de scope van de onderzoeker zijn gebleven, zoals bijvoorbeeld gebeurtenissen binnen de gemeentelijke organisaties zelf. Wat hier tegenover gezet wordt in dit onderzoek is de triangulatie: feitelijke gebeurtenissen én meningen zijn zowel in verschillende documenten binnen de feitenbeschrijving gevonden (notulen, dagboek, andere documenten), als in interviews en via enquêtes naar voren gekomen en onderling vergeleken. $0 p$ die wederzijdse bevestiging is de argumentatie gestoeld.

\subsubsection{Gevonden resultaten}

U it de analyse van de dimensie verandermanagement komt naar voren dat de GGD vele veranderacties uitvoerde, met een piek in 2003. H et zwaartepunt van deze acties lag op de factor sociaal ondernemerschap en beïnvloedingsstrategieën. $D$ it laatste betrof met name presentaties van resultaten aan raadscommissies, productie van voortgangsrapportages en nieuwsbrieven en 'free publicity'.

Verder valt op de relatief lage en relatief negatieve score op de factor leiderschap. $U$ it de triangulatie blijkt in algemene zin dat de acties met een informerend karakter door bestuurders en andere actoren als overwegend positief zijn beoordeeld. Wel lijkt het effect van die acties op het draagvlak in 2004 minder dan in 2003: sommige bestuurders en raadsleden blijken niet snel overtuigd door de gevonden effectresultaten (zie ook 10.4). D aarnaast is er bij enkele bestuurders kritiek op de methode (plaatsen in het wettelijk verplichte basispakket): zij vin- 
den dat de GGD hiermee financiering probeert af te dwingen.

$D$ e chronologische analyse levert een aanvullend beeld op. De veranderacties in 2002 en de eerste helft van 2003 waren redelijk adequaat en leidden tot opname van $\mathrm{H}$ artslag Limburg in gemeentelijke concept nota's. Echter, de voorbereiding van bezuinigingsvoorstellen door de gemeente $M$ aastricht blijft buiten de waarneming van de GGD. G egeven de context van een ondoorzichtig gemeentelijk besluitvormingstraject, blijken de veranderacties in de tweede helft van 2003 inadequaat. In deze moeilijke situatie schiet het leiderschap vanuit de GGD tekort: een gecoördineerd beleid om de bezuiniging te pareren komt onvoldoende en te laat van de grond. M et het inhoudelijke gelijk aan haar zijde (nota, wettelijk basispakket), lukt het de GGD en haar gemeentelijke bestuurders niet om de bijbehorende (M aastrichtse) financiering rond te krijgen. H et jaar 2004 start met aanhoudende pogingen om $\mathrm{M}$ aastricht en Valkenburg alsnog te overtuigen om mee te financieren, is het niet voor 2004, dan tenminste voor 2005. Echter, geconstateerd wordt dat de GGD de terughoudende inzet van deze twee gemeenten en daaruit voortvloeiende afkalving van $\mathrm{H}$ artslag Limburg te veel heeft laten gebeuren. H et leiderschap, dat aan de kaak stelt dat de opdracht tot continuering van $\mathrm{H}$ artslag Limburg onverenigbaar is met een gelijktijdige dubbele bezuiniging, is onvoldoende getoond.

$\mathrm{H}$ et contrast met de casus $\mathrm{M}$ argraten laat zien dat binnen gunstige contextuele omstandigheden het operationele verandermanagement van de GGD wel slaagt. $D$ ie variabelen betreffen met name de regierol van de gemeente en de timing. $H$ et verandermanagement betreft vooral de persoonlijke relaties tussen GGD en gemeente op alle niveaus en het leveren van passende informatie.

Behalve in M argraten wordt ook in het samenwerkingstraject tussen GGD en azM een gunstig verankeringsresultaat geboekt. $D$ it ondanks het feit dat de resultaten uit het effectonderzoek slechts heel beperkt zijn (H arting, 2006c). Succesfactoren zijn hier de regierol van het management en bestuur van het azM in combinatie met de inzet van operationele verandermanagementfactoren: sociaal ondernemerschap, beïnvloedingsstrategieen (o.a. externe subsidie) en netwerkontwikkeling. Blijkbaar waren deze factoren voldoende om de afwezigheid van sterk leiderschap vanuit de GGD te compenseren.

In het voorjaar 2004 blijkt verder dat de GGD niet opgewassen is tegen een belangenconflict tussen gemeenten onderling. Als de financiële tekorten om meerdere redenen oplopen en een dominant deel van de gemeenten niet meer wil of kan financieren, dan is de GGD -directie relatief machteloos en treedt regressie op naar de 'laagste gemene deler'. U iteindelijk is de G GD genoodzaakt om de bezuiniging intern op te lossen. Er volgt echter geen principiële discussie op managementniveau, er is geen leiderschap dat de bezuinigingen verdeeld over alle drie de wettelijke taken (infectieziekten, JGZ en GVO ). D e bezuinigingsdoelen worden binnen de GVO gerealiseerd. 


\subsubsection{Conclusie}

In de voorgaande paragrafen is de dimensie verandermanagement geanalyseerd op geleide van deelvraag 5 en 7: "In hoeverre bestaat er een relatie tussen het toegepaste veranderingsmanagement en de mate van veranderingen in draagvlak en bestuurlijke verankering?". D e gevonden resultaten laten zien dat er een vergelijking gemaakt kan worden tussen drie casussen binnen de casus $\mathrm{H}$ artslag Limburg: het traject tussen G GD en gemeente $M$ aastricht als voorbeeld van tekortschieten van verandermanagement en leiderschap, en de casus $M$ argraten en azM als geslaagde voorbeelden. Een belangrijk deel van de veranderacties van de GGD heeft een gunstig effect gehad. $M$ et name in het begin van het verankeringstraject, in de eerste helft van 2003, hebben sociaal ondernemerschap, beïnvloedingsstrategieën en netwerkontwikkeling bijgedragen aan draagvlak voor stappen in het verankeringstraject.

Echter, vanaf medio 2003 blijken deze factoren onvoldoende en het draagvlak nog wankel. $D$ an blijkt dat het verandermanagement geen grip heeft op deels ondoorzichtige bezuinigingsplannen van de gemeente $M$ aastricht, en tekortschiet op momenten waarop gemeenten geconfronteerd hadden moeten worden met eerdere afspraken. Kansen voor coalition building en het tonen van leiderschap worden gemist.

D e presentatie in april 2004 van aansprekende effectcijfers maakt het operationele verandermanagement nog niet doorslaggevend. Wel blijkt in $\mathrm{M}$ argraten de aanpak effectief dankzij de combinatie met een gunstige lokale context (regierol portefeuillehouder en timing). D eze gunstige combinatie ontbreekt in $M$ aastricht waar de resultaten te laat komen om de bezuinigingen terug te draaien. Binnen de GGD blijken de bezuinigingen merendeels afgewenteld te worden op de GVO -taken.

$H$ et contrast in de casussen laat zien dat als het ontbreekt aan sterk leiderschap vanuit de GGD dat de veranderacties ondersteunt, de kans groot is dat het resultaat mager is. Vooral op het terrein van gezondheidsbevordering, omdat daar de wettelijke eisen veel minder scherp geformuleerd zijn dan op aanpalende GGD -taakvelden. In de casus blijkt daarbij dat de lokale context, met name de regierol van gemeenten, inclusief timing, doorslaggevend is.

In het volgende hoofdstuk wordt de regierol van gemeenten in de casus nader geanalyseerd. 


\section{Hoofdstuk 9 De regierol van gemeenten}

\subsection{Inleiding}

In de vorige hoofdstukken is beschreven hoe het proces van bestuurlijke verankering in de casus $\mathrm{H}$ artslag Limburg is verlopen in de periode oktober 2002 tot oktober 2005. H oofdstuk 6 concludeert dat de belangenstrijd tussen actoren deels te wijten is aan een gebrekkige regie door gemeenten. In hoofdstuk 7 is de regierol van gemeenten gedefinieerd en benoemd als factor in het WIZ-model. $D$ e analyse van de dimensie verandermanagement in hoofdstuk 8 heeft het belang van leiderschap vanuit de GGD naar voren gehaald. Geconcludeerd is dat dit leiderschap alleen lijkt te functioneren als de gemeente haar regierol voldoende weet in te vullen. In dit hoofdstuk wordt de regierol van gemeenten in de casus nader op een rij gezet.

D e regierol van gemeenten in het kader van lokaal gezondheidsbeleid is in paragraaf 7.4 als gedefinieerd:

$>$ De regierol van gemeenten betreft een bijzondere vorm van sturen die is gericht op de afstemming van actoren, hun doelen en handelingen tot een meer samenhangend geheel, met het oog op een bepaald resultaat. Deze regievoering vereist een duidelijke gemeentelijke visie, die vertaald wordt in een politiek-bestuurlijke en ambtelijke prioriteitstelling, evenals het vaststellen van de daarvoor benodigde en beschikbare gemeentelijke middelen.

Daarentegen wordt gebrek aan regierol gekenmerkt door het vermijden van besluitvorming over politiek-bestuurlijke en ambtelijke prioriteiten, het negeren van verantwoordelijkheid voor het vaststellen van benodigde middelen en het ongebruikt laten van autoriteit.

D eze definitie is van toepassing op de gemeenten in de casus $\mathrm{H}$ artslag Limburg, en daarmee ook op het $A B$ en $D B$ van de GGD.

In paragraaf 9.2 worden de data over de regierol van de gemeenten gepresenteerd. Paragraaf 9.3 sluit af met een discussie en conclusie. 


\subsection{Resultaten regierol van gemeenten}

\subsubsection{Regierol van gemeenten: resultaten uit de feitenbeschrijving}

D e belangrijkste data uit de feitenbeschrijving over de regierol van gemeenten zijn de volgende.

Eind juni 2003 accordeert de raad in M aastricht de nota lokaal gezondheidsbe leid; in deze nota staat als doel: "H artslag Limburg inbedden in bestaande structuren". D it houdt in dat $\mathrm{H}$ artslag Limburg omgevormd moet worden tot een regulier G GD -product, maar tevens dat de apart functionerende Stuurgroep wordt opgeheven, zonder dat een alternatief voor overleg met de andere in $\mathrm{H}$ artslag Limburg deelnemende organisaties wordt geambieerd. Erger nog, rond deze datum liggen elders binnen de gemeente voorstellen klaar om op H artslag Limburg voor ruim 160 mille te bezuinigen. D e consequenties van de voorgenomen bezuiniging worden door de gemeente niet helder met de direct betrokkenen, GGD en welzijnswerk, besproken. Integendeel, in februari en maart 2003 wordt gesproken over vernieuwing van GSB-gelden en het ontzien van de GGD bij de al gemene bezuinigingen. Pas later in het jaar blijkt dat deze toezegging niet geldt voor GSB-gelden en projecten. Op 11 juli 2003 wordt in het D B van de GGD in eerste instantie alleen een algemene mededeling gedaan ("de GGD als geheel zal minder geld krijgen"), terwijl al op 9 juli een specifieke bezuiniging aan de orde is een raadscommissie.

Achtergrond en motivatie voor de $M$ aastrichtse bezuiniging behelst een nieuwe visie van de wethouder dat de bijdrage van het welzijnswerk thuishoort onder 'gezondheid'. D e strijdigheid van deze visie met de uitgangspunten van $\mathrm{H}$ artslag Limburg wordt nergens besproken. Tegen eerdere afspraken in (D 82) wordt met de bezuinigingen niet gewacht tot de resultaten van het lopende RIVM -onderzoek bekend zijn.

0 p 14 oktober 2003 verdedigt een plaatsvervangend wethouder in de raadscommissie Welzijn en volksgezondheid de bezuiniging op het welzijnsdeel van $\mathrm{H}$ artslag Limburg met een argument dat haaks staat op de visie en jarenlange werkwijze van $\mathrm{H}$ artslag Limburg, namelijk dat "de GGD -professional de functie van het welzijnswerk even doeltreffend maar goedkoper" zou kunnen vervullen. D eze feitelijk onjuiste argumentatie wordt in de commissie niet weersproken omdat niemand van de GGD op de hoogte was van de agenda.

O p 19 november 2003 wordt op ambtelijk niveau aangegeven dat de bezuinigingen door de gemeente $\mathrm{M}$ aastricht op $\mathrm{H}$ artslag Limburg "eigenlijk niet hadden moeten plaatsvinden" (D 112). De portefeuillehouder lost dit op door de verantwoordelijkheid voor de continuering van $\mathrm{H}$ artslag Limburg af te schuiven op de GGD : de bezuiniging moet niet als gezien worden als een afkeuring van het project en de GGD moet zorgdragen voor continuering binnen de beschik- 
bare middelen. DeGGD krijgt opdracht om intern keuzes te maken. De voorstellen waar de GGD mee komt passen echter niet binnen die opdracht: van $\mathrm{H}$ artslag Limburg blijft minder dan de helft over. D e gemeenten accepteren echter dit compromis. 0 p 12 januari 2004 vat de directeur van het welzijnswerk zijn mening over de regierol van de gemeente $M$ aastricht kernachtig samen: "onbehoorlijk bestuur als het gaat om het vaststellen van gemeentelijk gezondheidsbeleid en enkele maanden later weghalen van de benodigde financiën" (D 127).

In de gemeente $\mathrm{M}$ argaten wordt de regierol anders ingevuld. $\mathrm{H}$ ier voert de portefeuillehouder in 2004 een vasthoudend beleid. Kritische vragen van raadsleden leiden tot een doelgerichte interne regie: ambtenaren maken inhoudelijke aanpassingen, de GGD levert relevante data en het budget blijft overeind (zie 8.3.4). Dit resultaat blijkt echter van korte duur omdat de belangen van gemeenten onderling verbonden zijn. D e bezuiniging van de gemeente $M$ aastricht hebben een grote impact op de kleinere gemeenten: uiteindelijk willen zij in evenre digheid niet méér bijdragen dan M aastricht (D 148). In dit proces, medio 2004, blijken de uitgangspunten van het fusieproces dominant boven eerdere bestuurlijke keuzes: alle kosten moeten "inverdiend" worden, er komt geen geld bij. De gemeenten beslissen dat de drie wettelijke taken, JGZ, infectieziekten en GVO, overeind moeten blijven, maar het bestuur formuleert niet hoe zich dit verhoudt tot de opgelegde bezuinigingen. Tot slot: als er in april 2004 en april 2005 gunstige resultaten op niveau van effecten, respectievelijk kosteneffectiviteit uit onderzoek bekend worden, betreuren de bestuurders de eerdere bezuinigingen, maar concrete actie wordt niet ondernomen.

D eze opsomming uit de feitenbeschrijving laat zien dat het op meerdere momenten ontbrak aan het gericht afstemmen van actoren (beëindigen van Stuurgroep $\mathrm{H}$ artslag Limburg), aan het ontwikkelen van een visie (tegenstrijdig met eerdere afspraken, geen of tekortschietend overleg over welzijnscomponent), aan interne regie (ambtelijke voorbereiding bezuinigingsvoorstellen loopt los van schrijven van nota, gebrekkige communicatie met GGD ), aan besluitvorming over prioriteiten (wel in de nota, maar niet bij het overeind houden van de wettelijke GGD taken) en het vervolgens nemen van verantwoordelijkheid voor het vaststellen van benodigde middelen (bezuinigen op wat in de nota's juist is geprioriteerd). D e conclusie is dat deze elementen uit de definitie wijzen op een gebrekkig uitgevoerde regierol door gemeenten. 


\subsubsection{Regierol van gemeenten: resultaten uit interviews en enquêtes}

H oewel het onderscheid tussen verandermanagement en regierol van gemeenten bij de start van deze studie niet in specifieke vragen is geoperationaliseerd, blijkt het materiaal uit interviews en enquêtes hier toch het nodige over te kunnen aanreiken. U it de analyse van de gehouden interviews in 2003 en 2004 komt het volgende beeld naar voren.

Bij de geïnterviewde bestuurders is er zeker besef van de eigen regierol, zij het dat voor het terrein van de gezondheids-bevordering dit pas recent als zodanig gezien wordt.

$>$ "Het zou beter uitgelegd moeten worden en tijdig. De politiek beslist, maar nu met het duale stelsel ligt de verantwoording toch meer bij raadscommissies, dat zou ik doen. Ik denk dus vooral aan het informeren van de commissies en de portefeuillehouder is degene die verantwoordelijk is voor het feit dat het in het college aandacht krijgt." (43;27.08.2003)

"Maar de laatste grote bijeenkomst die we over Hartslag Limburg hebben gehad, toen is er ook een presentatie geweest van het RIVM, dan schrik ik wel, (..). Dat is ook in de lokale gezondheidsnota veel meer naar voren gebracht dat we ons als gemeente veel meer moeten verdiepen in dat soort gegevens en onderzoeken die komen, dat we dat ook veel meer moeten vertalen naar onze lokale situatie. Dat is denk ik voor de komende jaren de grootste opgave voor de invulling van je regierol. Je ook door dit soort elementen te laten inspireren om tot lokale invulling te komen, naast datgene wat we als basistakenpakket hebben. En traditioneel, dat moet ik er ook bij zeggen, ik zal niet de enige wethouder zijn, ligt de harde realiteit van groen, wegen, straten, pleinen, veiligheid en dergelijke, op een hogere prioriteit dan preventie in de openbare gezondheidszorg. Dat komt ook doordat gemeente dat in het verleden nooit hebben gezien als iets waar je echt voor moet gaan. Maar die regierol heb je." (81;17.09.2003)

Een jaar later is dit beeld wel aangescherpt. De ene portefeuillehouder schat de prioriteit intussen lager in en legt de verantwoordelijkheid buiten zichzelf, terwijl een ander weldegelijk verwijst naar tekortschietende regie door de gemeenten. 
$>$ "Gewoon in het GVO beleid, daar moeten ze het dan maar inbouwen. (...) Maar als je echt naar iedere euro moet kijken, dan verandert de zaak, dan zeg je van: dat kan dus nu niet meer, helaas." (57, 19.10.2004)

"Er zijn communicatief, zowel op ambtelijk als op bestuurlijk niveau, steken laten vallen, dat is niet goed gegaan. (...) In zijn directe relatie, ook gezien de grote van de bedragen, is Hartslag Limburg eigenlijk dubbel gepakt. (...) We hebben recentelijk vernomen dat Hartslag Limburg ook zijn effecten en eerste vruchten begon af te werpen, met de perspublicaties een aantal maanden geleden. En dan gaan wij op dat moment zeggen: ja ik vind het wel goed zo." (81;15.07.2004)

\section{Bij de directeur van het welzijnswerk is er stevige kritiek op de invulling door de gemeenten van de regierol:}

$>$ "Ja, de grote vraag is natuurlijk: zijn gemeenten in staat om die taken die ze op hun bordje krijgen ook goed vorm te geven? En daar hebben we in de afgelopen jaren ervaring mee dat dat niet altijd goed loopt, dat ze niet altijd in staat zijn om goed een regierol te voeren, een goed beleid helder te definiëren, niet alleen op abstractie niveau, maar vooral ook in de concreetheid van doelen en resultaten, daar ontbreekt het heel veel aan vind ik zelf. Gemeenten zijn niet zo goed in staat om hun eigen concrete beleidsdoelen te formuleren, dat merk ik naar Trajekt in algemene zin, maar als je het over beleidsterreinen hebt, waar we elkaar heel veel tegenkomen, daar waar de gemeenten steeds meer de opdracht krijgen om regie te voeren, daar ontbreekt het heel veel aan en dat is heel slecht. (...)

De expertise ontbreekt, de gemeenten werken daarin voor mijn gevoel ook teveel vanuit hun eigen structuur, ze zijn heel erg intern gericht, veelal, in plaats van dat ze met maatschappelijke organisaties aan tafel gaan zitten, zo van dit is de opdracht, dit kunnen we samen oppakken. Ze denken dat ze alles zelf moeten doen en dan gaan ze pas kijken hoe ze de maatschappelijke organisaties erbij betrekken. Dat vind ik nog altijd een manco in de wijze waarop het gaat.(...) Wat kan de gemeente nog anders doen? Prioriteiten stellen. De gemeente moet heldere keuzes maken, wat vindt ze van belang en waar zet ik dus geld op in. Dus, als ze vinden dat gezondheidsbeleid heel belangrijk is dan moeten ze ook durven daar voor te kiezen en geld in te zetten. Dat betekent dan dat ze het ergens anders niet in kunnen zetten en dat is dan een politieke keuze. Maar ik heb de indruk dat een keuze maken een heel lastig iets is voor een gemeente." (126;04.09.2003) 
H et lijkt er op dat deze kritiek door minstens één portefeuillehouder wordt erkend:

Het idee dat ik heb is dat we vanuit de gemeente dus teveel op de stoel gaan zitten van de uitvoerende organisaties. Dan heb ik het over het respecteren van de rollen en de autonomie, dat stuk autonomie wat je gewoon hebt, punt uit. En dat wordt vaak te zeer bekeken vanuit de relatie 'die betaalt, die bepaalt'. Maar dat kan ook zijn omwille van het feit dat we met elkaar, de gemeenten, dat je onvoldoende geduid hebt waar je met je preventieve gezondheidszorg naar toe wilt. (43;27.08.2003)

Een enkele portefeuillehouder durft de lijn uit 2003 door te trekken naar 2004:

$>$ Alleen is het wel zo dat wij als gemeente veel meer de regierol moeten nemen, dat we echt moeten zeggen: tot zover. We moeten ook echt de grenzen gaan aangeven en de openbare gezondheidszorg die ruimte geven waarvan wij denken dat nodig is." (81;17.09.2003)

"Wat ik me dus nu ook realiseer is dat wij over dit soort ontwikkelingen ook te weinig communiceren met verantwoordelijke bestuurders en dat zou wellicht nog eens een uitdaging voor de toekomst zijn. (...) We moeten dus überhaupt ook nog als gemeente wennen om de regie op dat terrein ook heel nadrukkelijk te gaan voeren, maar ook te gaan uitspreken wat we exact willen. Dat is voor ons een groeiproces, en we hebben de GGD nodig om ons daarbij te helpen en daarin te sturen. Hadden we dat wellicht twee of drie jaar eerder met elkaar in de genen gehad, hadden we wellicht al met elkaar bepaald: dan gaan we zeker niet op dat product bezuinigen." (81;15.07.2004)

$\mathrm{H}$ et beeld van een gebrekkige regie uit deze interviews wordt merendeels bevestigd door de resultaten uit enquêtes; dit ondanks het feit dat in de vragenlijst helaas geen specifiek onderscheid gemaakt is tussen bestuurlijke en uitvoerende regie (zie hoofdstuk 7), noch tussen GGD of gemeente als verantwoordelijke regisseur. In 2003 vindt ruim de helft van de respondenten (55\%) dat in de samenwerking binnen $\mathrm{H}$ artslag Limburg er een duidelijke regie is en dat die regie door de juiste partij gevoerd wordt. In 2004 is dit percentage echter gedaald tot ongeveer $41 \%$ van de respondenten: een meerderheid is dan dus neutraal tot negatief over de invulling van de regie (zie ook paragraaf 10.3.4). 


\subsection{Conclusie}

Triangulatie van data over de regierol van gemeenten laat zien dat de regierol van gemeenten op een reeks van cruciale onderdelen tekort schoot. D e gemeentelijke visie, vastgelegd in de nota lokaal gezondheidsbeleid, wordt niet vertaald in een prioriteitstelling, eerdere afspraken met andere actoren worden niet gehonoreerd, afstemming in de tijd met lopend onderzoek wordt beloofd maar niet waargemaakt, de interne regie schiet tekort en benodigde middelen worden in plaats van toegekend onder twee verschillende noemers (bij het welzijnswerk en bij de GGD ) wegbezuinigd. D it tekort aan regie speelt vooral in de dominante gemeente $M$ aastricht, maar uiteindelijk gaan de andere portefeuillehouders mee in de consequenties die dit oplevert. In interviews bevestigen enkele portefeuillehouders dat gemeenten "nog in die regierol moeten groeien".

$\mathrm{D}$ aar waar die regierol wel consequent wordt ingevuld, zoals in de casus $\mathrm{M}$ argraten, en blijkt samen te vallen met andere positieve factoren (verandermanagement en een gunstige timing), wordt ook een positief verankeringsresultaat geboekt, zij het tijdelijk (zie 8.3.4).

D eze resultaten bevestigen het belang en de invloed van de opname van de factor regierol van gemeenten binnen de dimensie lokale context van het W IZ-model (zie 7.6). 


\section{Hoofdstuk 10 Draagvlak}

\subsection{Inleiding}

Als laatste van de dimensies van het WIZ-model komt in dit hoofdstuk de dimensie 'draagvlak' aan bod. In het model wordt feitelijk onderscheid gemaakt tussen twee draagvlak-dimensies: 'determinanten van draagvlak' en 'uitingsvormen van draagvlak' (zie hoofdstuk 3). Binnen de eerste dimensie worden als 'determinanten' van draagvlak onderscheiden: 'doelstelling', 'belang', 'win-win', 'consensus' en 'sense of urgency'. D eze determinanten worden hierna om praktische reden 'factor' genoemd. D e factor sense of urgency, ook wel urgentiebesef genoemd, is in het model opgenomen op advies van het expertpanel (zie 3.4.5). D eze factor ontbreekt in de enquêtes daar deze zijn uitgezet in een eerdere onderzoeksfase; in beide andere databronnen is de factor wel meegenomen in de analyse. Als 'uitingsvormen' van draagvlak worden onderscheiden: 'onderling vertrouwen', 'tonen van betrokkenheid' en 'adaptatie'. In hoofdstuk 3 en bijlage 1 is beschreven hoe de dimensies en hun deelfactoren zijn gedefinieerd.

D e gegevensverzameling over deze twee dimensies en de acht factoren daarbinnen heeft plaatsgevonden via drie databronnen: de feitenbeschrijving, interviews en enquêtes. H ieronder is ervoor gekozen om de data uit deze drie bronnen eerst apart te presenteren (paragraaf $10.2 \mathrm{t} / \mathrm{m}$ 10.4). D aarna volgt de daadwerkelijke tijdreeksanalyse waarin triangulatie tussen de drie bronnen plaatsvindt (paragraaf 10.5).

\subsection{Draagvlak: resultaten uit de feitenbeschrijving}

In de figuren $10.1 \mathrm{t} / \mathrm{m} 10.10$ zijn de aantallen gebeurtenissen van de beide dimensies draagvlak uit de feitenbeschrijving weergegeven. Als eerste valt op dat er relatief weinig gebeurtenissen op deze dimensies gescoord zijn vergeleken bij de andere dimensies. Verklaring hiervoor kan zijn dat draagvlak in zijn determinanten en uitingen meer het karakter heeft van een mening en minder van een gebeurtenis. Anders gezegd: databronnen als interviews en enquêtes lenen zich wellicht beter om deze dimensie te scoren dan een analyse van documenten. Verder valt op dat binnen de dimensie 'determinanten' zowel positieve als negatieve gebeurtenissen zijn gescoord, terwijl bij 'uitingsvormen' van draagvlak vooral positieve gebeurtenissen zijn geregistreerd. D e uitsplitsing in de deelfactoren geeft een aanvullend inzicht. Binnen de dimensie 'determinanten van draagvlak' worden de positieve scores vooral bepaald door gebeurtenissen waar de doelstelling en de win-win van $\mathrm{H}$ artslag Limburg in positieve zin werd ge- 


\section{Determinanten van draagvlak}

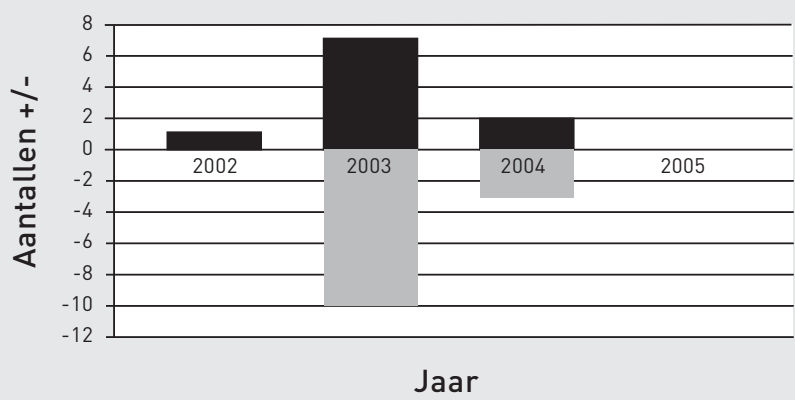

Negatief

Figuur 10.1 Totaal aantal gebeurtenissen Determinanten van draagvlak van de feitenbeschrijving

\section{4a. Doelstelling}

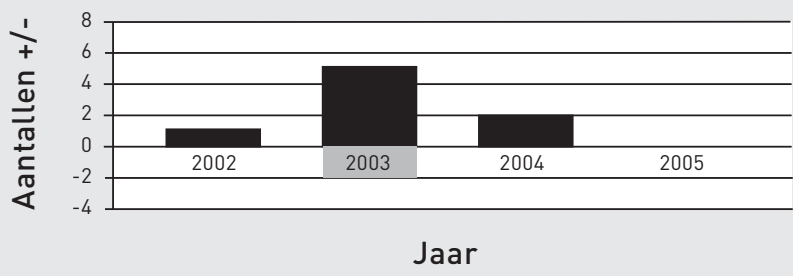

Figuur 10.2 Aantal gebeurtenissen van de factor Doelstelling

\section{4b. Belang}

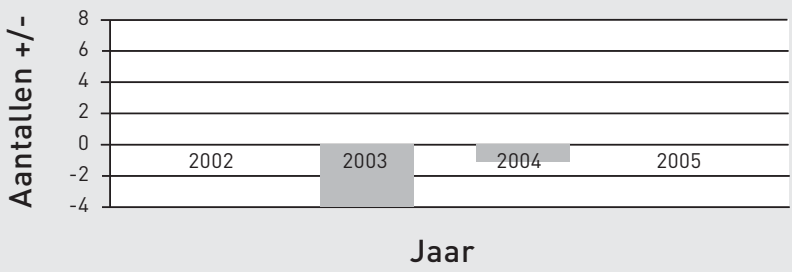

Figuur 10.3 Aantal gebeurtenissen van de factor Belang 


\section{4c. Win-win}

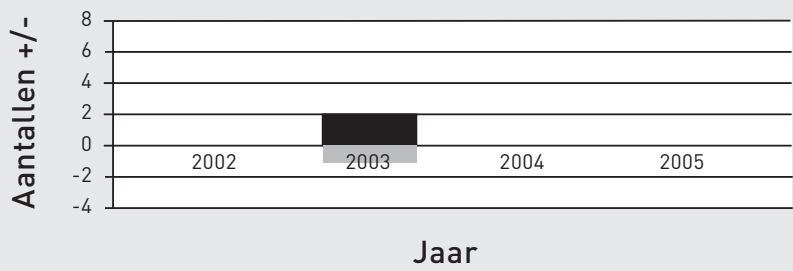

Positief

Negatief

Figuur 10.4 Aantal gebeurtenissen van de factor Win-win

\section{4d. Consensus}

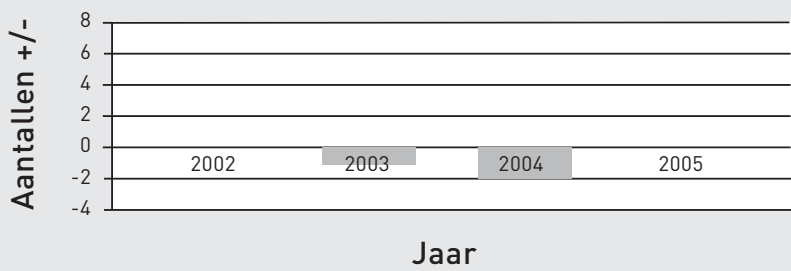

Figuur 10.5 Aantal gebeurtenissen van de factor Consensus

\section{4e. Sense of urgency}

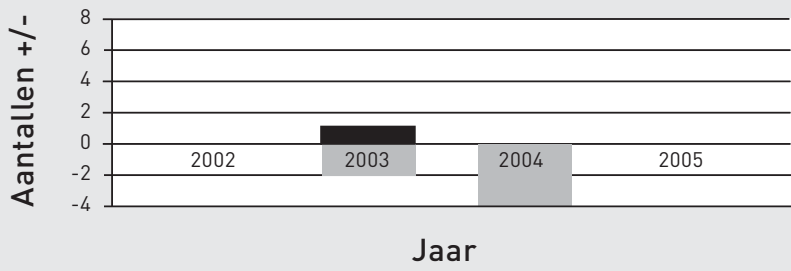

Figuur 10.6 Aantal gebeurtenissen van de factor Sense of urgency 


\section{Uitingsvormen van draagvlak}

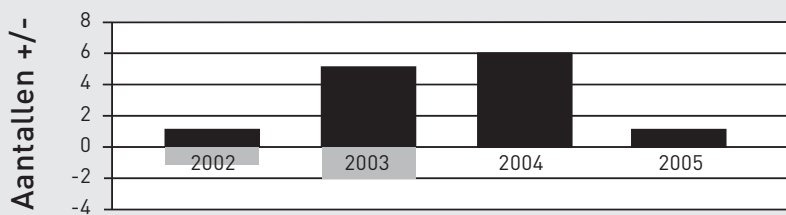

Jaar

Figuur 10.7 Totaal aantal gebeurtenissen van de dimensie Uitingsvormen van draagvlak

\section{5a. Onderling vertrouwen}

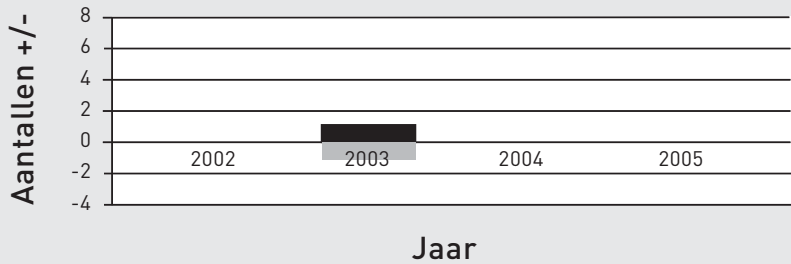

Positief

Negatief

Figuur 10.8 Aantal gebeurtenissen van de factor Onderling vertrouwen

$5 b$. Tonen van betrokkenheid
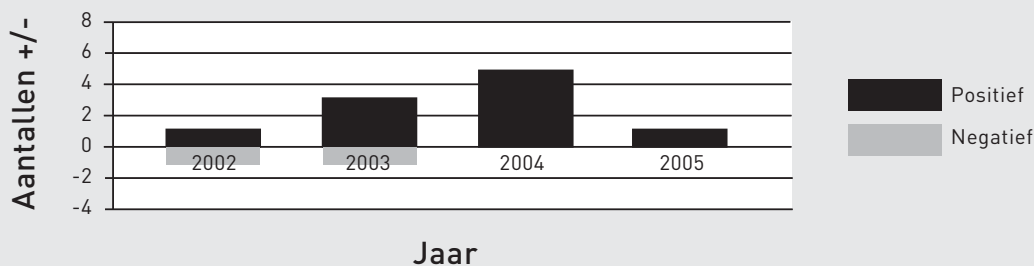

Figuur 10.9 Aantal gebeurtenissen van de factor Tonen van betrokkenheid 


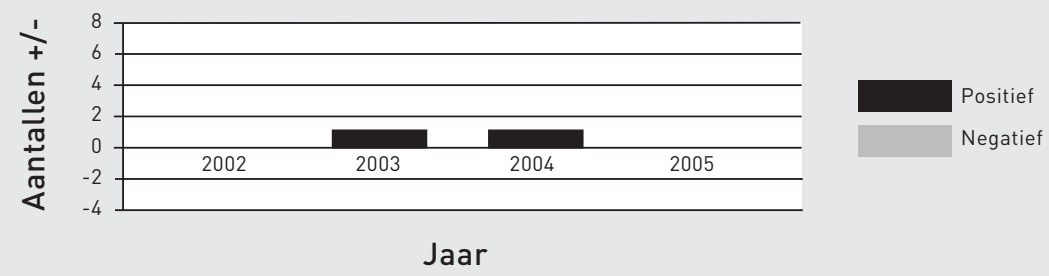

Figuur 10.10 Aantal gebeurtenissen van de factor Adaptatie

ventileerd. Echter, op de factoren belang, consensus en sense of urgency is enkel negatief gescoord. De inhoud van de geregistreerde gebeurtenissen wordt hieronder per factor toegelicht. D e uitsplitsing van factoren binnen de dimensie 'uitingsvormen van draagvlak' laat zien dat er met name gebeurtenissen zijn geregistreerd waarin de betrokkenheid in positieve zin werd getoond (factor $5 b$, figuur 10.9). Dit is opvallend, gelet op de aanwezigheid van veel negatieve scores binnen de dimensie determinanten van draagvlak. D it resultaat kan er wellicht op duiden dat positieve betrokkenheid gemakkelijker publiekelijk wordt getoond dan negatieve betrokkenheid. In de analyse wordt hier verder op ingegaan.

\subsubsection{Doelstelling}

D e factor 'doelstelling' betreft de mate waarin de doelen van $\mathrm{H}$ artslag Limburg belangrijk gevonden worden. In totaal zijn tien gebeurtenissen onder deze factor geregistreerd, waarvan acht positief en twee negatief (figuur 10.2). Positieve gebeurtenissen betreffen genotuleerde uitspraken van ambtenaren van de gemeente Eijsden en $\mathrm{M}$ aastricht dat zij het streven naar verankering ondersteunen gezien "de goede 'fit' met het lokale beleid" (D 28, D 39) en intern willen zoeken naar financiële mogelijkheden (D 127).

Positief beoordeeld zijn uitspraken van portefeuillehouders als "Er positief tegen aan te kijken vanwege de brede participatie op lokaal niveau" (D 41). In dezelfde lijn passen de uitspraken van de portefeuillehouder van Eijsden en M aastricht: "Er is inderdaad een wettelijke basis", en "H artslag Limburg is een duidelijk inhoudelijk verhaal; dat moet gewoon doorgaan" (D 101) en "de kwaliteit van het product is overtuigend" (D 127).

$N$ egatief is 0.a. gescoord waar de portefeuillehouder van M eerssen benadrukt dat de aanpak "nog helemaal niet bewezen effectief is" (D 41). 


\subsubsection{Belang}

D e factor 'belang' betreft een oordeel over het belang van de verankering van $\mathrm{H}$ artslag Limburg, ofwel de prioritering in vergelijking tot andere doelen (figuur 10.3). $\mathrm{H}$ ier is negatief gescoord vanwege meerdere uitspraken "dat er weliswaar een wettelijke basis is maar dat daarin het de gemeenten vrijstaat om hieraan een minimale dan wel een maximale invulling aan te geven" (D 101) en, dat continuering afhankelijk is van "nadere prioritering binnen de nieuwe nota" (D 41, D 101). Typerend zijn verder de negatief beoordeel de uitspraken in de raadscommissie $M$ argraten: " $H$ et CD A zal het ons zeer moeilijk maken. Als het om de GGD gaat kijken zij alleen naar kosten." (D 67); een woordvoerder van het CD A: "Wat is het effect van deze activiteiten? H oezo betreft dit een verplichte basistaak?" (D 165).

\subsubsection{Win-win}

D e factor 'win-win' betreft het oordeel over de balans tussen voor- en nadelen van de verankering van $\mathrm{H}$ artslag Limburg (figuur 10.4). $\mathrm{H}$ ier is negatief gescoord vanwege uitspraken dat een gezamenlijke financiering met Sport (in het kader van de landelijke regeling Breedte Sport Impuls) in M eerssen niet haalbaar zou zijn vanwege de lokale context (belangenstrijd tussen lokale sportclubs en gemeente) (D 41). Positieve scores betreffen 0.a. de afspraak tussen G GD en azM om $\mathrm{H}$ artslag Limburg te incorporeren in de ontwikkeling van het nieuwe $\mathrm{H}$ artVaatC entrum van het ziekenhuis en dit te combineren met een subsidieaanvraag bij het fonds $0 \mathrm{GZ}$ (D 81). 0 ok is positief gescoord de actie van een ambtenaar van de gemeente $\mathrm{M}$ argraten om $\mathrm{H}$ artslag Limburg te koppelen aan sport en zo het budget te verhogen van $€ 36.000$ naar $€ 51.000$ (D 104).

\subsubsection{Consensus}

D e factor 'consensus' (figuur 10.5) betreft zowel domeinconsensus (de overeenstemming over afbakening van taken en rollen) als ideologische consensus (0.a. overeenkomsten in cultuur, visie op samenwerking en op aandacht voor kwetsbare groepen). D e negatief beoordeelde gebeurtenissen betreffen de uitspraak van de portefeuillehouder in de raad van $\mathrm{M}$ aastricht dat " $\mathrm{H}$ artslag Limburg niet thuis hoort in de begroting van het welzijnswerk" (D 102), en uitspraken van de GGD -directeur: 
$>$ "Daarnaast zit er toch een domeinconflict tussen GGD en gemeenten. We zijn een gemeentelijke afdeling, maar de GGD ziet zichzelf toch ook als onafhankelijke professionele organisatie. Wat bij gemeenten weer kan leiden tot afstand en irritatie, en gemeentelijke ambtenaren die zich onvoldoende weten te beperken tot een strikt toezicht houdende taak. Dit laatste heeft de wethouder van Maastricht recentelijk in een DB ook gezegd over haar eigen ambtenaren." (D139)

\subsubsection{Sense of Urgency}

D e factor 'sense of urgency' betreft de aanwezigheid van een bewustzijn dat er snel en doortastend gehandeld dient te worden, in de casus de snelheid waarmee de besluitvorming over bestuurlijke verankering gerealiseerd dient te worden ('urgentiebesef'). D eze factor is na raadpleging van het expertpanel toegevoegd (zie 3.4.5). H ierbij moet vermeld worden dat deze factor wellicht niet zozeer spreekt uit specifieke gebeurtenissen als wel uit het totale verloop van de procesgang tussen GGD en gemeenten. Een proces dat immers ruim anderhalf jaar duurt (begin 2003 tot medio 2004). Bij de analyse van de feitenbeschrijving zijn niettemin zeven gebeurtenissen specifiek op deze factor gescoord, zes daarvan in negatieve zin (figuur 10.6). $\mathrm{H}$ et gaat hier telkens om momenten waarop bestuurders en ambtenaren het belang onderschrijven (bijvoorbeeld bij het vaststellen van de $\mathrm{M}$ aastrichtse nota) maar achterwege laten om de financiële voorwaarden in te vullen (portefeuillehouder in de $M$ aastrichtse raadscommissie: "H et is nog te vroeg om financiële haal baarheid te bepalen" (D 69)). Andere voorbeelden zijn: het overlaten van vinden van middelen januari 2004 aan de laagste ambtenaar, het ambtelijke voorstel begin 2004 om dat jaar de bezuiniging te accepteren en te proberen om voor $2005 \mathrm{H}$ artslag Limburg wel te prioriteren en de wijze waarop in maart/april 2004 noodoverleg over de financiering in het D B wordt afgesproken en vervolgens door de portefeuillehouder van $\mathrm{M}$ aastricht weer wordt afgezegd. 0 ok gescoord is het moeizame onderhandelingstraject om het latere product 'Lokale gezondheidsbevordering' opgenomen te krijgen in de begroting van 2005. D eze negatieve scores sluiten dicht aan bij gebeurtenissen die eerder benoemd zijn als elementen van een gebrekkige regierol door gemeenten (9.2.1) en elementen van tekortschietend leiderschap vanuit de GGD (8.2.5 en 8.3). $\mathrm{H}$ et is duidelijk dat in deze gebeurtenissen de drie genoemde factoren samenkomen. 


\subsubsection{Onderling vertrouwen}

D e factor 'onderling vertrouwen' (figuur 10.8) betreft het oordeel van actoren over mate waarin er sprake is van vertrouwen in de samenwerking of juist een sfeer van concurrentie. $0 p$ deze factor is relatief weinig gescoord in de feitenbeschrijving. D e positief gelabelde gebeurtenis betreft het besluit zomer 2003 van GGD en azM om een gezamenlijke werkgroep in te stellen naar aanleiding van de ontwikkelde gemeen schappelijke visie om de $\mathrm{H}$ artslag werkwijze in het ziekenhuis door te ontwikkelen en te incorporeren in de plannen voor een nieuw $\mathrm{H}$ artVaatC entrum (D 81). D e negatieve score betreft kritiek van de portefeuillehouder van Eijsden op de door de GGD gevoerde lobby voor continuering van $\mathrm{H}$ artslag Limburg (D 88).

\subsubsection{Tonen van betrokkenheid}

D e factor 'tonen van betrokkenheid' (figuur 10.9) betreft gezamenlijke planvorming, het nakomen van afspraken en het nemen van concrete voorbereidingen die nodig zijn om te komen tot inzet van mensen en middelen. De positief gescoorde gebeurtenissen betreffen 0.a. uitspraken van ambtenaren en bestuurders dat $\mathrm{H}$ artslag Limburg in de begroting is opgenomen (D 82), thuishoort in het basispakket van de GGD (D 101), past in de visie van het ziekenhuis (D 106) of past binnen de fusieplannen (D 184). N egatief zijn gelabeld gebeurtenissen waarin raadsleden of bestuurders zich openlijk uiten tegen voorbereidende stappen om financiering mogelijk te maken (o.a. D 67).

\subsubsection{Adaptatie}

D eze factor is slechts twee keer gescoord (figuur 10.10). In 2003 betrof dit aanpassingen in werkwijzen van de kant van de GGD en het azM in het kader van het $\mathrm{H}$ artVaatC entrum. In 2004 betrof dit de herstructurering van de afdeling $A G Z$ van de $G G D$, als bijdrage aan het terugdringen van de gemeentelijke kosten voor de continuering van $\mathrm{H}$ artslag Limburg.

\subsubsection{Conclusie uit de feitenbeschrijving}

Zoals al eerder gezegd: de data uit de feitenbeschrijving geven een kwalitatief beeld, en vanwege mogelijke selectiebias moet de grootte van de aantallen gebeurtenissen per factor met terughoudendheid worden geïnterpreteerd. 
D esalniettemin resteert vervolgens het beeld dat binnen de dimensie determinanten van draagvlak er zowel bevorderende als belemmerende factoren een rol spelen. Echter, de bevorderende gebeurtenissen concentreren zich op de gezamenlijke doelstelling en op win-win, terwijl op de overige determinanten de belemmerende gebeurtenissen duidelijk overheersen. Dit kan duiden op een wankel draagvlak.

D it beeld zet zich niet door in de dimensie uitingsvormen van draagvlak: hier overheersen de positieve gebeurtenissen. Dit wordt zichtbaar in de factor 'tonen van betrokkenheid', waar meerdere positieve stappen gedocumenteerd zijn. Echter, binnen deze factor valt op dat de 'tekenen-van-betrokkenheid-die-noodzakelijk-waren-maar-die-niet-gezet-werden' veel minder expliciet in documenten gevonden zijn, en dus ook niet gescoord zijn. D it is enerzijds een kwestie van een te kort schietende definiëring van de negatieve kant van deze factor, anderzijds wellicht ook van selectiebias. D e negatieve scores op de determinant 'sense of urgency' wijzen in feite al op een gebrek aan betrokkenheid, ook al is dit niet in duidelijke uitingsvormen te vinden. Geconcludeerd kan worden dat hier een valkuil ligt voor het verandermanagement: gebrek aan 'sense of urgency' en gebrek aan 'tonen van betrokkenheid' vallen niet altijd op.

\subsection{Draagvlak: resultaten uit enquêtes}

In de enquêtes is de dimensie determinanten van draagvlak gemeten op de factoren 'doelstelling', 'belang', 'win-win' en 'consensus'. D e dimensie uitingsvormen van draagvlak is gemeten op de factor 'onderling vertrouwen' en 'adaptatie'. De factor 'tonen van betrokkenheid' is niet via de enquêtes gemeten. Wel is in de enquête direct gevraagd naar de mening over verschillende aspecten van verankering van de samenwerking. D e belangrijkste uitkomsten zijn weergegeven in tabel $10.1 \mathrm{t} / \mathrm{m} 10.7$.

D e factoren 'doelstelling', 'belang' en 'consensus' zijn elk geoperationaliseerd met behulp van zes tot acht items. Van deze items zijn vervolgens per factor schalen geconstrueerd zodat van elke factor een score berekend kon worden. Van de factor consensus zijn twee schalen gemaakt om onderscheid te maken tussen domeinconsensus en ideologische consensus. Voor de schalen geldt dat score 1 wijst op goed draagvlak en score 5 wijst op slecht draagvlak. Bij voorbeeld: voor de factor 'doelstelling' is 0.a. gevraagd hoe belangrijk respondenten het vinden dat $\mathrm{H}$ artslag Limburg zich richt op het bevorderen van gezond gedrag, en hoe belangrijk men het acht om daar blijvend gezamenlijk aan te werken. Antwoorden met 'zeer belangrijk' kregen een 1, antwoorden met 'zeer onbelangrijk' kregen een 5 . Voor de factoren 'win-win', 'onderling vertrouwen' en 'adaptatie' zijn geen vijfpuntsschalen gemaakt omdat de individuele items daar- 
voor onderling teveel verschillen, dan wel de factor middels één item is gemeten.

\subsubsection{Doelstelling}

O p de schaal van 1-5 voor het belang dat respondenten hechten aan de doelstellingen van de samenwerking van $\mathrm{H}$ artslag Limburg komt de gemiddelde score in 2003 uit op 1,6 en in 2004 op 1,7. In beide jaren ligt de gemiddelde score dus nabij de ' $2=$ belangrijk'. D e verschillen tussen de sectoren waar respondenten uit afkomstig zijn, gemeenten, welzijnswerk, huisartsen, ziekenhuis, lopen weinig uiteen $(1,4$ tot 1,9$)$, waarbij gemeenten in beide jaren een middenpositie innemen. $0 p$ de individuele items lopen de scores in beide jaren uiteen van minimaal $75 \%$ tot maximaal $92 \%$ van de respondenten die de stellingen belangrijk tot zeer belangrijk vindt (tabel 10.1). D e verschillen tussen 2003 en 2004 zijn klein, en scores zijn in 2004 soms lager soms hoger dan in 2003. O p de vraag hoe belangrijk het is dat de gezamenlijk aanpak een blijvend karakter krijgt, antwoordt in 2003 86\% en in 2004 84\% belangrijk tot zeer belangrijk.

\subsubsection{Belang}

$\mathrm{O} p$ de schaal voor het belang dat respondenten hechten aan $\mathrm{H}$ artslag Limburg zijn items opgenomen als "Ik vind het belangrijk dat mijn gemeente bijdraagt" tot " $\mathrm{H}$ et is noodzakelijk dat we in onze regio het investeringsbedrag van $\mathrm{H}$ artslag Limburg minimaal handhaven". Zowel in 2003 als 2004 komt de gemiddelde score op deze schaal uit op 2,0 (2 = "tamelijk eens"). 


\begin{tabular}{|c|c|c|c|c|c|c|c|c|}
\hline \multirow[t]{2}{*}{ Item uit vragenlijst } & \multicolumn{2}{|c|}{$\begin{array}{l}\text { 'onbelangrijk' } \\
\text { en 'zeer } \\
\text { belangrijk' }\end{array}$} & \multicolumn{2}{|c|}{ neutraal' } & \multicolumn{2}{|c|}{$\begin{array}{l}\text { 'belangrijk' } \\
\text { en 'zeer } \\
\text { belangrijk' }\end{array}$} & \multicolumn{2}{|l|}{ totaal (n) } \\
\hline & 2003 & 2004 & 2003 & 2004 & 2003 & 2004 & 2003 & 2004 \\
\hline $\begin{array}{l}\text { Hoe belangrijk vindt u dat Hartslag Limburg zich richt } \\
\text { op bevorderen gezond gedrag in algemene bevolking? }\end{array}$ & 1 & 10 & 12 & 2 & 87 & 89 & $100(78)$ & $100(52)$ \\
\hline $\begin{array}{l}\text { Hoe belangrijk vindt u het bevorderen van gezond gedrag } \\
\text { groepen met gezondheidsachterstand? }\end{array}$ & 2 & 6 & 8 & 4 & 90 & 90 & $100(78)$ & $100(52)$ \\
\hline $\begin{array}{l}\text { Hoe belangrijk vindt u het bevorderen van gezond gedrag } \\
\text { bij hoogrisicopatiënten? }\end{array}$ & 5 & 10 & 9 & 4 & 86 & 87 & $100(78)$ & $100(52)$ \\
\hline $\begin{array}{l}\text { Hoe belangrijk vindt u het realiseren van transmurale } \\
\text { samenwerking? }\end{array}$ & 5 & 12 & 18 & 12 & 76 & 76 & $100(76)$ & 100 (49) \\
\hline $\begin{array}{l}\text { Hoe belangrijk vindt u het dat partijen gezamenlijk aan } \\
\text { doelen werken? }\end{array}$ & 3 & 4 & 5 & 10 & 92 & 86 & $100(77)$ & $100(51)$ \\
\hline $\begin{array}{l}\text { Hoe belangrijk vindt u het dat de gezamenlijke aanpak } \\
\text { een blijvend karakter krijgt? }\end{array}$ & 1 & 4 & 13 & 12 & 86 & 84 & $100(77)$ & $100(51)$ \\
\hline
\end{tabular}

Tabel 10.1 Draagvlak: factor doelstelling (percentages van het totaal) 


\begin{tabular}{|c|c|c|c|c|c|c|c|c|}
\hline \multirow[t]{2}{*}{ Item uit vragenlijst } & \multicolumn{2}{|c|}{$\begin{array}{l}\text { 'tamelijk oneens' } \\
\text { en 'geheel } \\
\text { oneens' }\end{array}$} & \multicolumn{2}{|c|}{ 'neutraal' } & \multicolumn{2}{|c|}{$\begin{array}{l}\text { 'tamelijk eens' } \\
\text { en 'geheel } \\
\text { eens' }\end{array}$} & \multicolumn{2}{|l|}{ totaal (n) } \\
\hline & 2003 & 2004 & 2003 & 2004 & 2003 & 2004 & 2003 & 2004 \\
\hline $\begin{array}{l}\text { Ik vindt het belangrijk dat gemeenten (c.q. mijn gemeente) } \\
\text { in regio bijdragen aan Hartslag Limburg. }\end{array}$ & 5 & 2 & 13 & 4 & 81 & 94 & $100(75)$ & $100(52)$ \\
\hline $\begin{array}{l}\text { Ik vind dat Hartslag Limburg (c.q. healthcounseling) een } \\
\text { belangrijke bijdrage levert aan realisering van de doelen } \\
\text { van mijn eigen organisatie. }\end{array}$ & 9 & 6 & 15 & 10 & 76 & 85 & $100(78)$ & $100(52)$ \\
\hline $\begin{array}{l}\text { Hartslag Limburg (c.q. healthcounseling) is goed } \\
\text { inpasbaar binnen prioriteiten van het beleid van mijn } \\
\text { eigen organisatie. }\end{array}$ & 7 & 10 & 21 & 18 & 73 & 73 & $100(77)$ & $100(51)$ \\
\hline $\begin{array}{l}\text { De centrale doelen van mijn organisatie zijn ook } \\
\text { haalbaar zonder samenwerking met partners van } \\
\text { Hartslag Limburg. }\end{array}$ & 51 & 57 & 24 & 25 & 24 & 18 & $100(74)$ & 100 (49) \\
\hline $\begin{array}{l}\text { Gezien landelijke trends is het noodzakelijk dat we samen } \\
\text { blijven werken aan gezondheidsbevordering. }\end{array}$ & 3 & 4 & 8 & 10 & 90 & 87 & $100(78)$ & $100(52)$ \\
\hline $\begin{array}{l}\text { Gezien landelijke trends is het noodzakelijk dat het } \\
\text { investeringsbedrag van Hartslag Limburg minimaal } \\
\text { gehandhaafd blijft. }\end{array}$ & 7 & 14 & 12 & 6 & 81 & 80 & $100(74)$ & $100(50)$ \\
\hline
\end{tabular}

Tabel 10.2 Draagvlak: factor belang (percentages van het totaal) 
Verschillen tussen de sectoren zijn in 2004 iets groter $(1,4$ tot 2,2) dan in 2003 $(1,9$ tot 2,3$)$, waarbij de sector gemeenten in beide jaren uitkomt op 1,9. Bij de individuele items valt op dat twee vragen leiden tot en gemiddeld lager percentage 'tamelijk eens tot geheel eens'. O $\mathrm{p}$ de vraag of $\mathrm{H}$ artslag Limburg goed inpasbaar is in het beleid van de eigen organisatie antwoordt $72 \%$ in beide jaren tamelijk tot geheel eens. En op de vraag of de centrale doelen van de eigen organisatie ook haalbaar zijn zonder samenwerking met de partners van $\mathrm{H}$ artslag Limburg antwoordt 51\% (2003) resp. 57\% (2004) 'tamelijk tot geheel oneens'. D it laatste is een bevestiging van de moeilijke positie van gezondheidsbevordering: gezondheidsbevorderaars zijn meer afhankelijk van derden dan dat die partners afhankelijk zijn van hen. Voor een belangrijk deel is de gezondheidsbevordering afhankelijk van goodwill. Tot slot het item over het handhaven van de financiering. $\mathrm{O} p$ de stelling " $\mathrm{H}$ et is noodzakelijk dat in onze regio het investeringsbedrag van $\mathrm{H}$ artslag $\mathrm{Limburg}$ minimaal gehandhaafd blijft" (tabel 10.2) antwoordt $80 \%$ van de respondenten in beide jaren het daar 'tamelijk tot geheel eens' mee te zijn. D eze constatering moet echter wel afgezet worden tegen de positie van de respondenten. $\mathrm{H}$ et is nu eenmaal gemakkelijker om het eens te zijn met het handhaven van een investering wanneer men er niet zelf voor hoeft te betalen. In dit licht is het opvallend dat de scores binnen de sector gemeenten, onder zowel ambtenaren als raadsleden, niet afwijkt van het gemiddelde. Vanuit deze invalshoek bezien lijkt het draagvlak, ook bij gemeenten, weldegelijk redelijk groot.

\subsubsection{Win-win}

D e factor win-win is onderzocht met de vraag of de voordelen voor de eigen organisatie groter zijn dan de nadelen. In 2003 acht 51\% de voordelen groter, in 2004 is dit percentage gestegen tot 60\%. Tegelijkertijd is het percentage respondenten dat de nadelen groter acht gestegen van $8 \%$ in 2003 naar $25 \%$ in 2004. De meningen gaan met de tijd dus sterker verschillen.

0 mgezet in een schaal score ( $1=$ voordeel is groter, $2=$ nadeel is groter) stijgt de win-win iets in de periode 2003 - 2004: van 1,5 naar 1,4. H oewel de verschillen tussen de sectoren klein zijn, valt op dat de gemeenten steeds de hoogste positie inneemt (1,6 en 1,5 in 2003, resp. 2004): daar lijkt de win-win aan meer twijfel onderhevig. 


\begin{tabular}{|c|c|c|c|c|}
\hline Win-win & \multicolumn{2}{|l|}{2003} & \multicolumn{2}{|l|}{2004} \\
\hline Item uit vragenlijst & $\begin{array}{l}\text { percentage } \\
\text { 'ja' }\end{array}$ & $\begin{array}{l}\text { totaal } \\
\text { (n) }\end{array}$ & $\begin{array}{l}\text { percentage } \\
\text { 'ja' }\end{array}$ & $\begin{array}{l}\text { totaal } \\
\text { (n) }\end{array}$ \\
\hline $\begin{array}{l}\text { Als u voor uw organisatie de voor- en } \\
\text { nadelen afweegt, tot welke conclusie } \\
\text { komt u dan? }\end{array}$ & & & & \\
\hline De voordelen zijn groter dan de nadelen & 51 & $100(78)$ & 60 & $100(52)$ \\
\hline De nadelen zijn groter dan de voordelen & 8 & $100(78)$ & 19 & $100(52)$ \\
\hline De voor- en nadelen zijn in evenwicht & 8 & 100 (78) & 25 & $100(52)$ \\
\hline
\end{tabular}

Tabel 10.3 Draagvlak: factor win-win (percentages van het totaal)

\subsubsection{Domeinconsensus}

D omeinconsensus is onderzocht door vijf vragen over respect voor ieders identiteit, overeenstemming over taak en werkterrein en duidelijkheid over de regie. Anders dan bij de factoren doelstelling en belang vinden we hier lagere scores 'enigszins tot geheel eens'. D e gemiddelde schaalscore ligt in 2003 op 2,4, in 2004 op 2,5. O p de individuele items zijn alle scores in 2004 lager dan in 2003. $\mathrm{H}$ et beeld in 2004 is duidelijk ongunstiger. Consensus over taken en regie is afgenomen. Verschillen tussen de sectoren zijn klein in beide jaren, en gemeenten nemen een middenpositie in.

D e individuele items over regie scoren het laagst. $0 p$ de vraag "In de samenwerking met $\mathrm{H}$ artslag Limburg is er een duidelijke regie" antwoordt 55\% (2003) resp. 41\% (2004) met 'enigszins tot geheel eens'. O p de vraag "In de samenwerking met $\mathrm{H}$ artslag Limburg wordt de regie gevoerd door de juiste partij" antwoordt 56\% (2003) resp. 43\% (2004) met 'enigszins tot geheel eens'. D e conclusie is dat domeinconsensus tussen 2003 en 2004 afnam, met name op het punt van de regie. 0 nduidelijkheid over wie nu de regie behoorde te voeren nam toe. 


\begin{tabular}{|c|c|c|c|c|}
\hline Domeinconsensus & 2003 & & & \\
\hline Item uit vragenlijst & $\begin{array}{l}\text { 'enigzins } \\
\text { oneens' en } \\
\text { 'geheel } \\
\text { oneens' }\end{array}$ & neutraal' & $\begin{array}{l}\text { 'enigzins } \\
\text { eens' en } \\
\text { 'geheel } \\
\text { eens' }\end{array}$ & totaal (n) \\
\hline $\begin{array}{l}\text { In de samenwerking in het kader van } \\
\text { Hartslag Limburg ervaar ik dat: } \\
\text { - er duidelijk respect is voor ieders identiteit } \\
\text { - er overeenstemming is over ieders taak } \\
\text { - er overeenstemming is over de afbakening } \\
\text { van ieders werkterrein } \\
\text { - er een duidelijke regie is } \\
\text { de regie wordt gevoerd door de juiste partij }\end{array}$ & $\begin{array}{l}3 \\
11 \\
11 \\
16 \\
12\end{array}$ & $\begin{array}{l}21 \\
26 \\
37 \\
\\
30 \\
32\end{array}$ & $\begin{array}{l}75 \\
63 \\
53 \\
55 \\
56\end{array}$ & $\begin{array}{l}100(61) \\
100(57) \\
100(57) \\
100(64) \\
100(59)\end{array}$ \\
\hline
\end{tabular}

\begin{tabular}{|c|c|c|c|c|}
\hline \multirow{2}{*}{$\begin{array}{l}\text { Domeinconsensus } \\
\text { Item uit vragenlijst }\end{array}$} & \multicolumn{4}{|l|}{2004} \\
\hline & $\begin{array}{l}\text { 'enigzins } \\
\text { oneens' en } \\
\text { 'geheel } \\
\text { oneens' }\end{array}$ & neutraal' & $\begin{array}{l}\text { 'enigzins } \\
\text { eens' en } \\
\text { 'geheel } \\
\text { eens' }\end{array}$ & totaal (n) \\
\hline \multicolumn{5}{|l|}{ In de samenwerking in het kader van } \\
\hline Hartslag Limburg ervaar ik dat: & & & & \\
\hline - er duidelijk respect is voor ieders identiteit & 5 & 32 & 64 & $100(44)$ \\
\hline - er overeenstemming is over ieders taak & 18 & 30 & 52 & $100(44)$ \\
\hline $\begin{array}{l}\text { - er overeenstemming is over de afbakening } \\
\text { van ieders werkterrein }\end{array}$ & 16 & 36 & 48 & $100(44)$ \\
\hline - er een duidelijke regie is & 18 & 41 & 41 & $100(44)$ \\
\hline de regie wordt gevoerd door de juiste partij & 14 & 43 & 43 & $100(42)$ \\
\hline
\end{tabular}

Tabel 10.4 Draagvlak: factor domeinconsensus (percentages van het totaal) 


\subsubsection{Ideologische consensus}

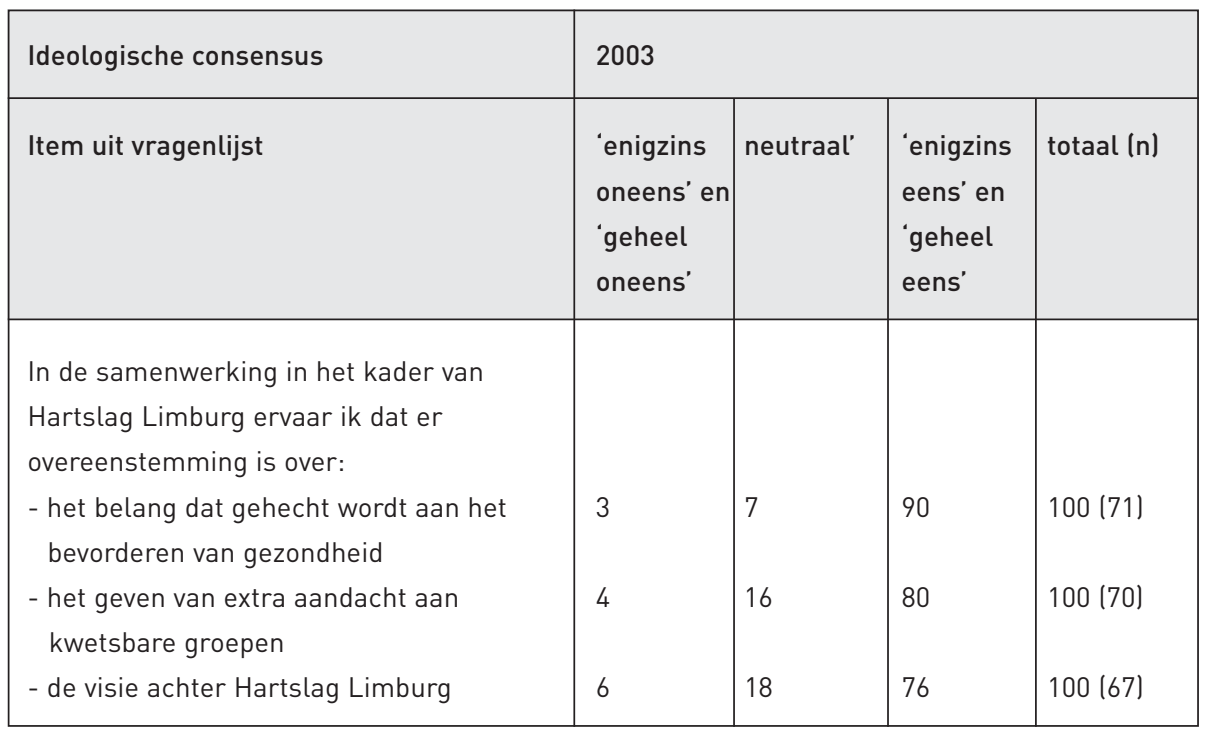

\begin{tabular}{|c|c|c|c|c|}
\hline Ideologische consensus & 2004 & & & \\
\hline Item uit vragenlijst & $\begin{array}{l}\text { 'enigzins } \\
\text { oneens' en } \\
\text { 'geheel } \\
\text { oneens' }\end{array}$ & neutraal' & $\begin{array}{l}\text { 'enigzins } \\
\text { eens' en } \\
\text { 'geheel } \\
\text { eens' }\end{array}$ & totaal (n) \\
\hline $\begin{array}{l}\text { In de samenwerking in het kader van } \\
\text { Hartslag Limburg ervaar ik dat er } \\
\text { overeenstemming is over: } \\
\text { - het belang dat gehecht wordt aan het } \\
\text { bevorderen van gezondheid } \\
\text { - het geven van extra aandacht aan } \\
\text { kwetsbare groepen } \\
\text { - de visie achter Hartslag Limburg }\end{array}$ & 6 & $\begin{array}{l}6 \\
19 \\
17\end{array}$ & $\begin{array}{l}94 \\
77 \\
77\end{array}$ & $\begin{array}{l}100(48) \\
100(48) \\
100(48)\end{array}$ \\
\hline
\end{tabular}

Tabel 10.5 Draagvlak: factor ideologische consensus (percentages van het totaal) 
I deologische consensus is onderzocht met behulp van drie items naar de ervaren overeenstemming over het belang dat gehecht wordt een gezondheidsbevordering, de aandacht voor kwetsbare groepen en de gezamenlijke visie. D e gemiddelde schaal score in 2003 is 1,9, in 2004 1,8 (2=enigszins eens). Er zijn geen opvallende verschillen tussen sectoren. $0 p$ de individuele items zijn de scores relatief hoog: 76 tot $94 \%$ van de respondenten is het enigszins tot geheel eens met de stellingen. Anders gezegd, ruim driekwart van de respondenten ervaart een redelijke mate van ideologische consensus.

\subsubsection{Onderling vertrouwen}

O nderling vertrouwen is onderzocht op basis van vier items. $0 p$ alle individuele items zien we een afname in 2004 ten opzichte van 2003 in de percentages tamelijk tot geheel eens' (bij twee items in termen van 'tamelijk tot geheel oneens' in verband met een negatieve formulering van de vraag). $0 p$ de stelling dat er tussen partners een sfeer van concurrentie heerst, antwoordt in $200365 \%$ van de respondenten het hier tamelijk tot geheel oneens mee te zijn; in 2004 is dit percentage gedaald tot $55 \%$. Analoog hieraan daalt het percentage tamelijk tot geheel oneens op de vraag of partners uit zijn op eigen gewin van $70 \%$ naar $52 \%$, en daalt het percentage tamelijk tot geheel eens met de stelling dat afspraken worden nagekomen van 69\% naar 50\%. D e conclusie luidt dat tussen medio 2003 en medio 2004 het onderling vertrouwen afnam. 


\begin{tabular}{|c|c|c|c|c|}
\hline Onderling vertrouwen & 2003 & & & \\
\hline Item uit vragenlijst & $\begin{array}{l}\text { 'tamelijk } \\
\text { oneens' en } \\
\text { 'geheel } \\
\text { oneens' }\end{array}$ & neutraal' & $\begin{array}{l}\text { 'tamelijk } \\
\text { eens' en } \\
\text { 'geheel } \\
\text { eens' }\end{array}$ & totaal (n) \\
\hline $\begin{array}{l}\text { De samenwerkingspartners binnen Hartslag } \\
\text { Limburg zijn competent voor hun taken. } \\
\text { Onderlinge afspraken worden nagekomen. } \\
\text { De samenwerking met de verschillende } \\
\text { actoren binnen Hartslag Limburg vindt } \\
\text { plaats in een sfeer van concurrentie } \\
\text { De samenwerkingspartners binnen. } \\
\text { Hartslag Limburg zijn uit op eigen gewin. }\end{array}$ & $\begin{array}{l}0 \\
65\end{array}$ & $\begin{array}{l}32 \\
22\end{array}$ & $\begin{array}{l}69 \\
13\end{array}$ & $\begin{array}{l}100(54) \\
100(54)\end{array}$ \\
\hline
\end{tabular}

\begin{tabular}{|c|c|c|c|c|}
\hline Onderling vertrouwen & 2004 & & & \\
\hline Item uit vragenlijst & $\begin{array}{l}\text { 'tamelijk } \\
\text { oneens' en } \\
\text { 'geheel } \\
\text { oneens' }\end{array}$ & neutraal' & $\begin{array}{l}\text { 'tamelijk } \\
\text { eens' en } \\
\text { 'geheel } \\
\text { eens' }\end{array}$ & totaal (n) \\
\hline $\begin{array}{l}\text { De samenwerkingspartners binnen Hartslag } \\
\text { Limburg zijn competent voor hun taken. } \\
\text { Onderlinge afspraken worden nagekomen. } \\
\text { De samenwerking met de verschillende } \\
\text { actoren binnen Hartslag Limburg vindt } \\
\text { plaats in een sfeer van concurrentie } \\
\text { De samenwerkingspartners binnen. } \\
\text { Hartslag Limburg zijn uit op eigen gewin. }\end{array}$ & $\begin{array}{l}9 \\
0 \\
55\end{array}$ & $\begin{array}{l}50 \\
33\end{array}$ & $\begin{array}{l}62 \\
50 \\
12\end{array}$ & $\begin{array}{l}100(47) \\
100(40) \\
100(42)\end{array}$ \\
\hline
\end{tabular}

Tabel 10.6 Draagvlak: factor onderling vertrouwen (percentages van het totaal)

\subsubsection{Adaptatie}

D e factor adaptatie is onderzocht met de vraag of naar aanleiding van de samenwerking binnen $\mathrm{H}$ artslag Limburg aanpassingen van een aantal typen ge 
troffen zijn in de eigen organisatie. In 2003 antwoordt 46\% van de respondenten dat aanpassingen zijn getroffen, in 2004 betreft dit 52\%. D e aanpassingen betreffen merendeels de aanstelling van een vast contactpersoon en/of de aanpassing van de interne werkwijze.

\subsubsection{Draagvlak voor verankering van samenwerking}

D irect gevraagd naar de mening of de samenwerking binnen $\mathrm{H}$ artslag Limburg verankerd dient te worden in het beleid van de deelnemende organisaties antwoord meer dan driekwart van de respondenten 'ja', waarvan ongeveer de helft 'zeker' en de helft 'wellicht' (tabel 10.7). Vooral het percentage 'ja, wellicht' laat zien dat het draagvlak dat er is, toch nog wankelbaar is.

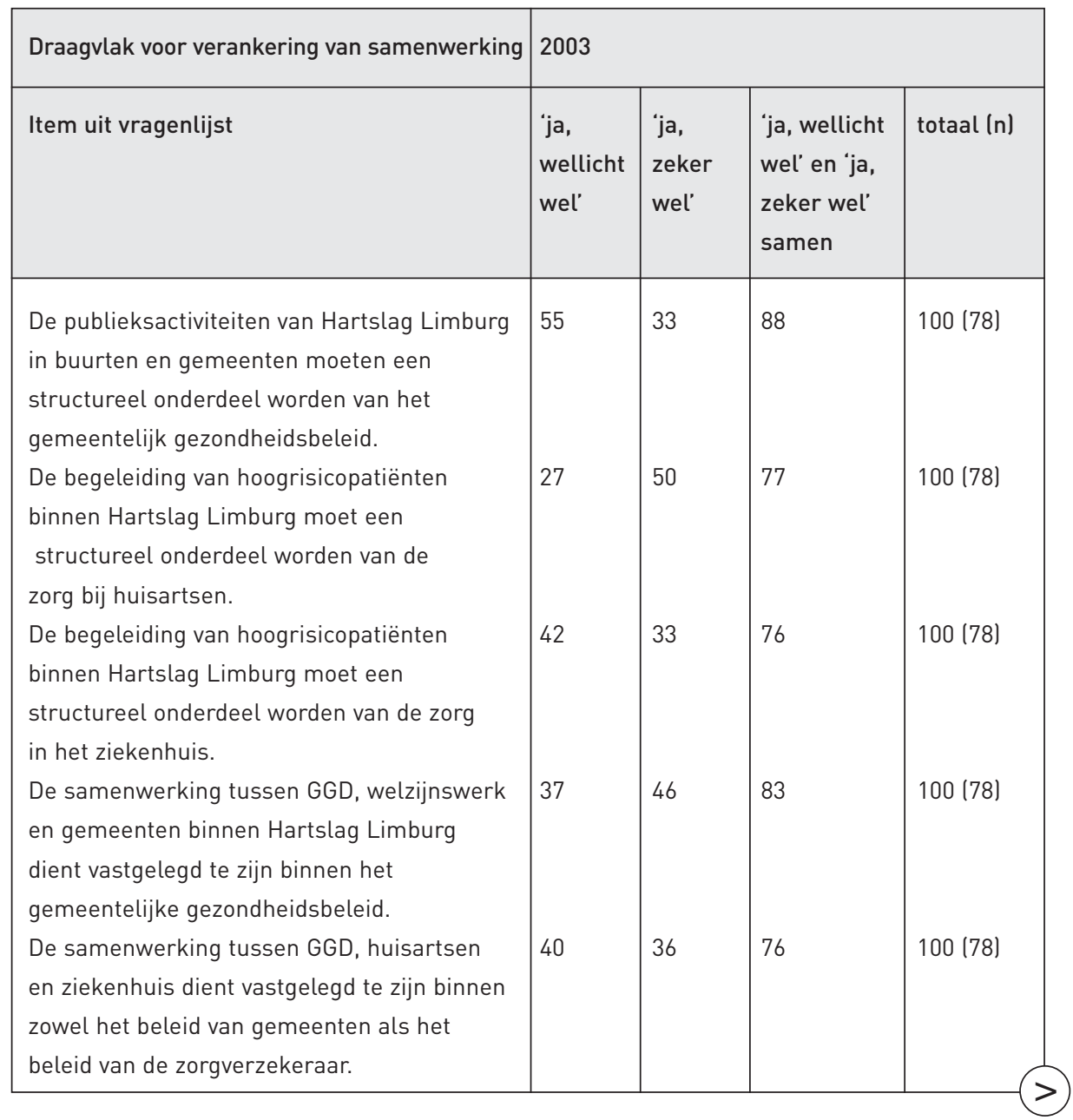




\begin{tabular}{|l|l|l|l|l|}
\hline $\begin{array}{l}\text { Bovengenoemde samenwerkingsafspraken } \\
\text { moeten voor een meerjarige periode worden } \\
\text { vastgelegd. }\end{array}$ & 38 & 47 & 85 & $100(77)$ \\
\hline
\end{tabular}

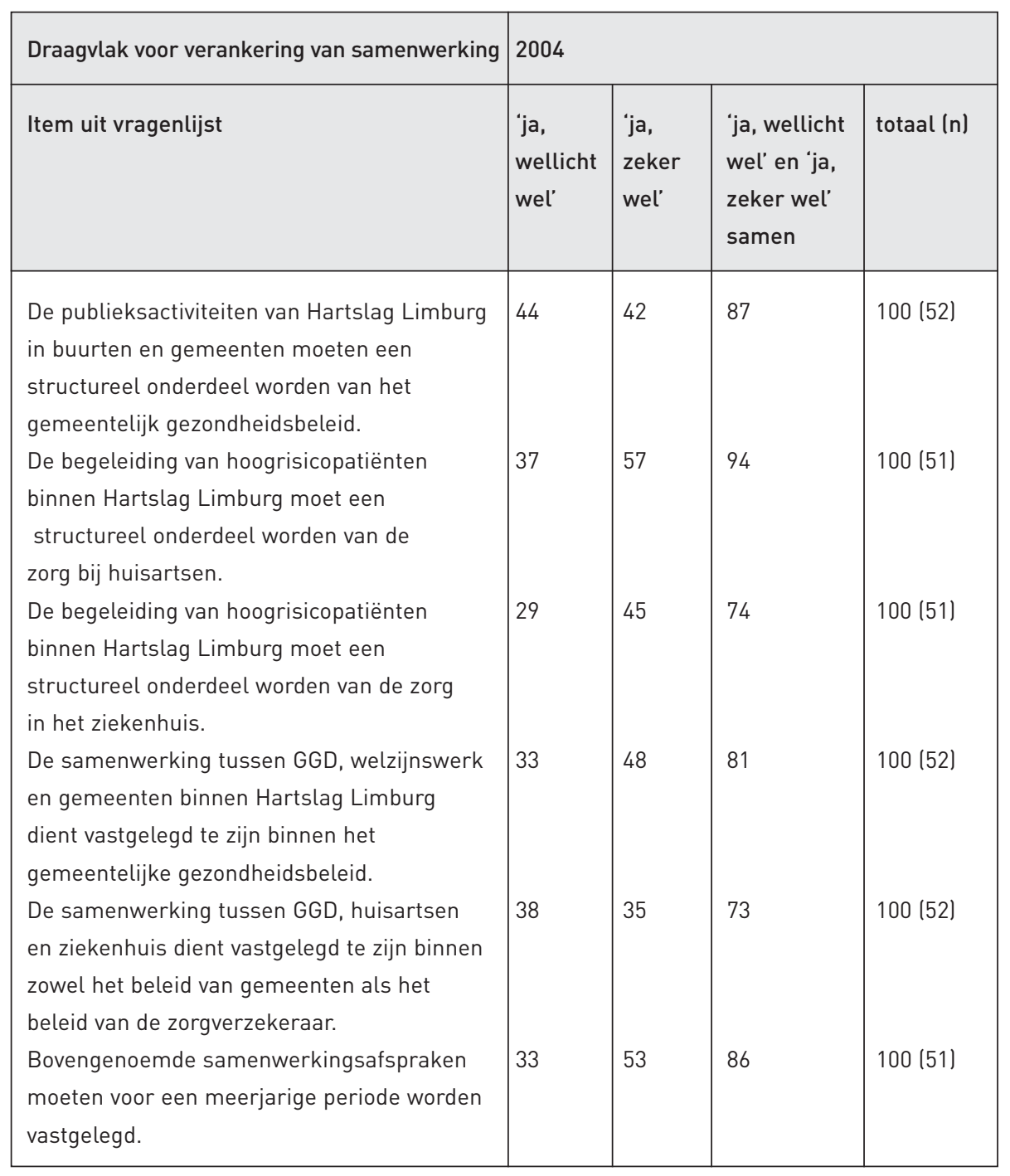

Tabel 10.7 Draagvlak: mening van respondenten over de verankering van samenwerking (percentages van het totaal) 


\subsubsection{Conclusie resultaten enquêtes}

U it de analyse van de resultaten van de enquêtes van 2003 en 2004 komt over het algemeen een redelijk goed draagvlak naar voren. Dit blijkt met name uit de factoren doelstelling, belang en ideologische consensus: ruim driekwart van de respondenten is op deze factoren positief. D e verschillen tussen de sectoren gemeenten, welzijnswerk, huisartsen en ziekenhuis zijn over het algemeen klein. D e nuancering zit hem vooral in de ervaren win-win en de duidelijkheid over de regie (domeinconsensus): deze scores liggen lager en dalen deels in 2004 verder. $D$ it correspondeert vervolgens met lagere scores op de factor onderling vertrouwen (concurrentiesfeer en eigen gewin).

Samengevat is de conclusie over de dimensie draagvlak dat men de belang van het onderwerp qua inhoud deelt, dat een hoog percentage (ook onder ambtenaren en raadsleden) vindt dat het investeringsniveau gehandhaafd moet blijven, maar er treedt toch een polarisatie op ten aanzien van de ervaren win-win en ten aanzien van de vraag wie de regie heeft (GGD of gemeente); dit alles gaat samen met een in 2004 dalend niveau van onderling vertrouwen. $\mathrm{H}$ et draagvlak dat er in meerderheid is, is deels tamelijk wankel.

D eze conclusie uit de enquêtes bevestigt de conclusie uit de feitenbeschrijving. 0 ok al zien we op details verschillen tussen beide bronnen, de algemene teneur is dat er draagvlak is voor zowel de doelstelling als het belang van de samenwerking. Verder bevestigt deze analyse het domeinconflict tussen gemeenten en GGD, het gebrek aan onderling vertrouwen en de kwetsbaarheid van het aanwezige draagvlak. Kortom: men vindt het doel belangrijk maar is het minder eens over de uitvoering.

\subsection{Draagvlak: resultaten uit interviews}

U it analyse van de interviews met bestuurders komt vooral naar voren het verschil tussen de factor doelstelling en het oordeel over het belang in relatie tot de beperkte middelen. In 2003 wordt er nog verschillend over gedacht, maar de hamvraag naar de benodigde middelen klinkt wel al duidelijk door:

$>$ "Voor mij heeft het een hoge prioriteit, en vind ik dat het een duidelijke plek moet krijgen binnen lokaal beleid." (55;14.08.2003)

"Ik denk dat het vooral gecontinueerd moet worden" (43;27.08.2003)

"Ik vind dat het absoluut doorgezet moet worden, want het is volksziekte nummer één, alleen moeten wij beoordelen qua financiële impact, hoe wij dat inbouwen in ons basistakenpakket." (81;17.09.2003) 
$>$ "Het zou eigenlijk wel binnen het gemeentelijk beleid vastgelegd moeten worden, maar het is wel afhankelijk van het geld. (...) Maar ja, het is geen onderwerp waar snel om gevraagd wordt. Op het totaal van gemeentelijke prioriteiten scoort gezondheid uiteindelijk toch niet erg hoog. (..) Als er later dit jaar toch forse bezuinigingen op ons afkomen dan zal Hartslag Limburg op de lijst van afvallers komen te staan." Even verderop: "Te hoge kosten.(.) Als we moeten kiezen tussen geld besteden aan de harmonie of Hartslag, dan kiezen we voor de harmonie, want dat geeft het minste gezeur. De afwegingen in de lokale politiek gaan nu eenmaal niet altijd op inhoudelijke gronden." (57;13.08.2003)

"Het mooiste voorbeeld is nu, in tijden van recessie of als het economisch wat minder gaat, dan moet je kijken waar er bezuinigd gaat worden en daar wordt niet gekeken naar effecten of wat dan ook, dat is gewoon heel plat, zo van waar kan ik dat weghalen?' Zonder dat je dan teveel oppositie creëert bij de mensen waar het dan om gaat." (43;27.08.2003)

Toch weet een enkele bestuurder het gewicht van de totale kosten te relativeren:

$>$ Ja, men kijkt ook naar de enorme bedragen die met dit soort projecten gemoeid gaan. Men vergeet die bedragen te relativeren in die zin, dat als men ze zou vertalen naar een bedrag per inwoner, of het afzetten tegen andere projecten, dan is het natuurlijk maar een spotprijsje. Maar het bedrag in absolute zin, daar wordt tegenop gekeken. (55;14.08.2003)

D e vijfde gemeentelijke bestuurder koppelt de verankering vooral aan landelijke financiering:

$>$ "Je zou het in de WCPV kunnen vastleggen, maar dan moet je er ook een prijskaartje aan hangen. Als je als landelijke overheid zegt dat je dit als een duidelijke preventieve activiteit ziet, dan moet je er natuurlijk ook geld bijleggen. Vanuit de landelijke kaders, gewoon belastinggeld, gemeentefonds, en dat doet men dus helemaal niet." (22;22.09.2003)

$0 p$ de factor win-win worden heel wisselende uitspraken gedaan: sommige bestuurders zien een positieve relatie met andere beleidsterreinen, andere opmerkingen getuigen meer van een gering belang van gezondheidbeleid binnen het gemeentelijke beleid. 
$>$ "Nou, voor de gemeente heeft dat geen voordeel, althans geen direct voordeel. De gemeente is natuurlijk gebaat bij een goede gezondheidstoestand van zijn burgers, maar hoe sterk die rol is, dat blijft altijd de vraag." (55;14.08.2003)

O pvallend is dat de directeur van het welzijnswerk de win-win van de brede samenwerking veel helderder dan de portefeuillehouders weet te verwoorden:

$>$ Het voordeel voor mijn organisatie is eigenlijk de expertise en de onderbouwing, de verwetenschappelijking van de informatiegegevens en de dingen waar je mee bezig bent, dat vind ik een heel groot voordeel van Hartslag Limburg. Dat is één kant, twee is dat in termen van PR en communicatie is het natuurlijk een fantastisch instrument, je merkt toch dat iedereen weet waar het over gaat als je het over Hartslag Limburg hebt. (126;04.09.2003)

Verder is domeinconsensus met name een punt als het gaat om de regierol van gemeenten: de kritiek hierop is in hoofdstuk 9 verwoord.

D aar waar de urgentie ter sprake komt is duidelijk dat bestuurders een echte 'sense of urgency' niet tonen, noch bij anderen aanwezig achten.

$>$ Ik verwacht zelf dat de eerstkomende jaren de financiën de doorslag zullen geven. Dat betekent inleveren, net zoals op alle terreinen ingeleverd zal moeten worden. Op termijn verwacht ik dat het anders zal worden, op het moment dat men het besef krijgt dat het toch wel verschrikkelijk belangrijk is om er iets mee te doen. (55; 14.08.2003)

\section{En opnieuw valt de directeur van het welzijnswerk op in helderheid:}

$>$ Het kan niet meer zo zijn dat instellingen alleen maar met hun eigen thema's bezig zijn. Die tijd is voorbij. Dus thema's moeten in keten- en samenwerkingsverbanden, in partnerships aangepakt worden.(..) I k vind dat er een samenwerkingsovereenkomst moet zijn, heel helder wie wat doet, voor wat verantwoordelijk is. Dit moet voor langere duur en voldoende geld en personeel moet eraan worden gekoppeld. Je moet op elkaar kunnen bouwen, en zeker voor de lange termijn is dit heel belangrijk, zeker bij dit soort projecten. Dit is niet een project wat je maar twee jaar doet. (126;04.09.2003) 
Analyse van de interviews met bestuurders van 2004 geven op individueel niveau een nauwelijks gewijzigd beeld: degenen die sceptisch waren doen vergelijkbare uitspraken, de gematigd positieve bestuurders zien lichtpuntjes:

$>$ "Maar het is wel zo, op dit moment is Hartslag Limburg in de basisvorm een onderdeel geworden van het basistakenpakket, we hebben het onder de wettelijke taken WCPV gebracht, dat is winst." $(81 ; 15.07 .2004)$

$\mathrm{H}$ et is ook deze portefeuillehouder die de continuering van $\mathrm{H}$ artslag Limburg niet langer afschuift op een gebrek aan middelen:

$>$ "Nee, dat denk ik niet. Als gemeenten ruim in het jasje zitten zullen ze hun wettelijke taken oppakken en komen ook andere beleidsvelden met vragen. Dus je zal die verantwoordelijkheid moeten nemen. (..) En daar vind ik dat we met het nieuwe lokale gezondheidsbeleid, dat we redelijk meetbare indicatoren met elkaar zouden moeten formuleren: wat is dan nu nodig aan inzet van onze middelen. Zodat ik straks kan zeggen: in 2004 waren we hier in situatie nul en in 2008 zijn we in situatie één. Nou, ik vind wel dat we vele malen meer die kant op moeten gaan en er is één elementje die bewezen heeft dat ook te kunnen en dat is Hartslag Limburg geweest. Die hebben gezegd: dit is de nul situatie, en na vijf jaar kwamen ook de eerste resultaten." (81;15.07.2004)

M aar zelfs met de positieve resultaten die in april 2004 gepubliceerd worden is het voor sommige bestuurders nog niet gemakkelijk:

$>$ Interviewer: "Hoe wordt er in de gemeente op de resultaten van het RIVM gereageerd?"

Reactie: "Dat heb ik inderdaad gelijk gebruikt, van kijk eens, hier staat het. 'Ja ja ja', zeggen ze dan, 'Dat zal wel'. Ja, daar wordt nog een beetje laconiek op gereageerd. (..) Maar men zegt: 'Ik heb Hartslag Limburg niet nodig om tot die gezondere levensstijl te komen'." (55;28.07.2004)

(Terzijde: juist in deze gemeente, Margraten, gaat de raadscommissie in april 2004 na presentatie en toelichting door de GGD akkoord met continuering van Hartslag Limburg.) 
$\mathrm{H}$ et uiteindelijk resulterende niveau van draagvlak onder bestuurders uit de interviews wordt aardig samengevat in het volgende citaat uit 2003:

$>$ "Ambtelijk is dat draagvlak er wel, bestuurlijk te weinig. Dat zijn zowel de politiek als het college van B\&W, en de Raad. Ik proef gewoon dat men een beetje meewarig blijft kijken, zo van: waar doen we dat nou allemaal voor, heeft dat nou allemaal wel zin? Moeten we daar geld aan besteden?" (55;14.08.2003)

\subsection{Triangulatie en conclusie}

Triangulatie van de drie bronnen op de dimensie draagvlak laat zien dat er een aantal duidelijke overeenkomsten zijn, enkele verschillen, plus een paar specifieke aanvullingen.

U it alle drie de bronnen komt naar voren dat de doelstelling en werkwijze van de samenwerking op een ruim maar deels kwetsbaar draagvlak kan rekenen. Wanneer dit belang afgewogen moet worden tegen andere prioriteiten dan blijken portefeuillehouders echter terughoudender dan de gemiddelde respondent uit de enquêtes, inclusief ambtenaren en raadsleden. Bij de bestuurders lijken de financiën, met name de dreigende bezuinigingen, een zwaardere druk te leggen op het draagvlak. Of dat echt zo is, of dat de bezuinigingen vooral makkelijker zijn af te wentelen op het soort projecten als $\mathrm{H}$ artslag Limburg, kan op basis van meerdere citaten vermoed worden. Bij bezuinigingen telt enerzijds "het minste gezeur", terwijl anderzijds wordt opgemerkt dat "ook bij een ruimer zittend jasje (...) de gemeente haar verantwoordelijkheid moet nemen" en de kosten vergelijkbaar zijn met "een spotprijsje".

In dit spanningsveld tussen deelfactoren binnen de dimensie draagvlak kunnen wellicht de overige factoren de doorslag geven. $D$ an valt op dat win-win wat lager scoort, met name bij gemeenten. Bovendien blijkt dat er tussen GGD en gemeenten onvoldoende domeinconsensus is en dat gemeenten hun regierol gebrekkig invullen. Verder blijkt uit feitenbeschrijving en interviews een gebrek aan 'sense of urgency' bij zowel portefeuillehouders als de GGD -directeur.

Complementair zijn de bronnen als het gaat om de uitingsvormen van draagvlak. U it de enquêtes blijkt dat een in 2004 dalend onderling vertrouwen in termen van 'concurrentiesfeer' en 'eigen gewin' door een relevante minderheid wordt gesignaleerd. $D$ e feitenbeschrijving laat verder zien dat gemeentelijke bestuurders en ambtenaren meermaals hun betrokkenheid toonden ("is opgenomen in de begroting"), echter dit interpreteren als aanwezigheid van draagvlak met een grote kans op verankering, blijkt voorbarig. $H$ et kan alsnog verkeren. 
Een onderzoeksmatige les geldt het definiëren van de factor 'tonen van betrokkenheid'. Belangrijk blijkt het definiëren en meten van de negatieve kant van de factor: het ontbreken van tonen van betrokkenheid op de noodzakelijke momenten. D e negatieve kant van de factor zegt waarschijnlijk meer over het feitelijke draagvlak dan de positieve. D aarnaast kan hieruit voor de praktijk een belangrijke les voor verandermanagers getrokken worden. G ebrek aan 'sense of urgency' en gebrek aan 'tonen van betrokkenheid' vallen niet altijd op. Je moet er zeer alert op zijn. H et toepassen van die alertheid is een factor die hoort bij succesvol leiderschap.

Tot slot: hoewel er uit de enquêtes geen onderscheid blijkt tussen de sectoren, is het beeld na triangulatie met de andere bronnen dat het draagvlak bij gemeentelijke bestuurders geringer was dan bij de overige actoren, inclusief ambtenaren en raadsleden. $D$ at beeld spoort met het in hoofdstuk 4 beschreven uitkomstniveau van verankering. $D$ e vraag in hoeverre er een relatie bestaat tussen de dimensies draagvlak en verankering (onderzoeksdeelvraag 6 en 7) lijkt beantwoordt te kunnen worden door opnieuw te kijken welke factoren in de casus in positieve zin hoog scoren en welke factoren de twijfel in het draagvlak aangeven. Vanuit die inval shoek is de conclusie dat hoge positieve scores op 'doelstelling' en 'tonen van betrokkenheid' alléén onvoldoende relatie laat zien met verankering. D aarnaast laten de negatieve scores op de factoren 'belang', 'sense of urgency' en 'tonen van betrokkenheid' een aantal redenen zien voor de gebrekkig gerealiseerde verankering in de casus. Wellicht mogen we dit ook omdraaien: de kans dat het aanwezige draagvlak zal leiden tot bestuurlijke verankering is vooral groot als bestuurders, naast enthousiasme over de doelstelling, positieve signalen afgeven op de factor 'belang' (in verhouding tot andere prioriteiten), en voldoende urgentiebesef tonen door concrete voorbereidingen voor de inzet van mensen te (laten) treffen. 


\section{Hoofdstuk 11 Conclusies en aanbevelingen}

\subsection{Inleiding}

Voor de beantwoording van de centrale vraagstelling van dit onderzoek is een zogenoemde 'embedded' single case study gedaan naar de casus $\mathrm{H}$ artslag Limburg over de periode oktober 2002 - oktober 2005. Voor de ordening van data, de analyse en het zoeken naar verklaringen is het W IZ-model gebruikt. D e veronderstelling van de gekozen onderzoeksopzet is dat uit de casus inzichten gegenereerd kunnen worden die leiden tot het beantwoorden van de centrale vraagstelling.

Paragraaf 11.2 bevat de conclusie uit de casus en de hierop gebaseerde algemene conclusie die een antwoord biedt op de centrale vraagstelling. In paragraaf 11.3 volgt de discussie wat die al gemene conclusie betekent voor de praktijk. In paragraaf 11.4 volgt een beschouwing op de onderzoeksopzet, waarna paragraaf 11.5 afsluit met de aanbevelingen.

\subsection{Conclusies}

\subsubsection{Conclusies uit de casus Hartslag Limburg}

$0 p$ basis van de in de voorgaande hoofdstukken gepresenteerde resultaten volgt hier een overzicht van de conclusies uit de casus. $N$ et als bij de indeling van de hoofdstukken wordt hierbij het ordeningskader van het W IZ-model gebruikt.

O $\mathrm{m}$ te beginnen bleek uit het onderzoek dat de context waarbinnen de G GD verankering van de bestuurlijke samenwerking van $\mathrm{H}$ artslag Limburg nastreefde ongunstig was. Ten aanzien van deze context is onderscheid gemaakt tussen externe (landelijke) factoren en de lokale context.

\section{Externe factoren}

Externe factoren waren merendeels ongunstig vanwege de discrepantie tussen, enerzijds, het uitbrengen van landelijke richtlijnen en, anderzijds en tegelijkertijd, het ontbreken van landelijke financiering. Vooral de specifieke korting op het $\mathrm{G}$ emeentefonds, een indirect gevolg van de stagnatie van onze nationale economie op dat moment, werkte door in de lokale context. H ierdoor kwam een cascade van ongunstige gebeurtenissen op gang. 


\section{Lokale context}

In de lokale context van de relatie tussen GGD en gemeenten droegen zowel incidentele als structurele factoren bij aan deze cascade van ongunstige gebeurtenissen. Incidentele factoren waren de stroeve samenwerkingsrelatie, de tekortschietende financiële transparantie van de GGD, het verschil in visie op de eindigheid van projecten, en het fusietraject tussen drie Zuid-Limburgse GGD 'en. D e term 'incidenteel' duidt hier op de factoren die specifiek waren voor de casus op dat moment. $D$ it in tegenstelling tot factoren die als structureel, ofwel blijvend en generaliseerbaar, aan te duiden zijn. Een structurele factor is de be langenstrijd tussen GGD en gemeente op vijf thema's. D ie vijf thema's betreffen de concurrentie om beleidsprioriteiten binnen de GGD -taken, de keuze tussen investeren of bezuinigen, de scheiding tussen welzijn en gezondheid (in plaats van een integrale aanpak), de spanning tussen lokaal of regionaal (iedere gemeente voor zich of regionaal afstemmen) en de dubbele-pet-constructie van portefeuillehouders die tevens GGD -bestuurder zijn. De grote gemene deler van de vijf thema's van de belangenstrijd is de strijd om geld. H et gaat om keuzes voor lokale beleidsdoelen en het toekennen van de middelen die daarvoor nodig zijn. In de casus blijkt die belangenstrijd geleid te hebben tot opvallende beleidsinconsistenties. D it duidt op een gebrekkige regierol door gemeenten (zie onder). D e belangenstrijd leidt ertoe dat investeringen in innovatie en ontwikkeling van gezondheidsbevordering uitblijven. $\mathrm{H}$ et thema gezondheidsbevordering verliest de strijd in de concurrentie met de infectieziektebestrijding (IB) en de jeugdgezondheidszorg (JGZ). D e wettelijke en professionele eisen liggen voor de JGZ en de IB veel gedetailleerder vast dan voor de gezondheidsbevordering. Verder gaven bestuurders aan bij bezuinigingen op gezondheidsbevordering weinig maatschappelijk verzet te verwachten.

$\mathrm{N}$ adere analyse op de factor regierol van gemeenten leidt tot de conclusie dat die rol in de casus inderdaad gebrekkig is ingevuld. O ndanks eerdere afspraken was er geen afstemming van het moment van de gemeentelijke besluitvorming over de continuering met de oplevering van resultaten uit wetenschappelijk onderzoek naar processen, effecten en kosteneffectiviteit; duidelijke beleidskeuzes bleven uit, behalve dat projecten 'per definitie' konden worden gestopt; er kwam geen alternatief voor de breed samengestelde Stuurgroep van H artslag Limburg; de uitwerking van de samenhang tussen gezondheids- en welzijnsbeleid liet op zich wachten, de intergemeentelijke regie schoot tekort en de gemeente $M$ aastricht bezuinigde, kort na het vaststellen van de nota, dubbel op de benodigde middelen.

Samenvattend laat de analyse van de dimensies externe factoren en lokale context zien dat het GGD -verandermanagement in de richting van de gemeenten, be halve door externe factoren, ook door lokale factoren in een ronduit ongunstig klimaat moest opereren. 


\section{Verandermanagement}

In deze ongunstige omgeving heeft het verandermanagement van de GGD desalniettemin veel activiteiten ontplooid op operationel niveau. D e analyse maakt duidelijk dat in de eerste helft van 2003 sociaal ondernemerschap, bënvloedingsstrategieën en netwerkontwikkeling hebben bijgedragen aan draagvlak voor stappen in het verankeringstraject, zowel bij gemeenten als in het azM . D e boodschap die in deze periode over het voetlicht kwam, betrof vooral de visie, de procesresultaten en een eerste effectresultaat (een significante daling in de vetconsumptie onder de jongere helft van respondenten ( $<49$ jaar) ten opzichte van controleregio (Ronda et al., 2004). Dit leidde er bij gemeenten toe dat $\mathrm{H}$ artslag Limburg werd opgenomen in (concept)nota's. In het ziekenhuis leidde de inzet tot gezamenlijke planontwikkeling voor inbouw van $\mathrm{H}$ artslag Limburg in een nieuw $\mathrm{H}$ artVaatC entrum. Pas vanaf april 2004 was uitgebreidere communicatie mogelijk over de effectcijfers en later ook over de gunstige kosten effectiviteit van het gemeentelijke deel van $\mathrm{H}$ artslag Limburg (Schuit et al., 2006; Ronckers, 2006b). D e presentatie van de gunstige resultaten kwam te laat voor de besluitvorming in de gemeente $M$ aastricht, was op tijd voor de besluitvorming in de gemeente $\mathrm{M}$ argraten (met een positief verankeringsresultaat als ge volg), maar bleek uiteindelijk onvoldoende om de beoogde bestuurlijke verankering in alle gemeenten te realiseren.

$0 p$ de andere factor van verandermanagement, het tonen van leiderschap op directioneel niveau, was het optreden gebrekkig. Positief was onder meer de standvastigheid ten aanzien van het onderbrengen van $\mathrm{H}$ artslag Limburg binnen het wettelijk verplichte basispakket. M aar confrontatie van gemeenten met eerdere afspraken en benutten van de eigen autoriteit bleef op andere momenten uit. Enerzijds is dit gebrek aan leiderschap te begrijpen gezien de lokale context en andere G GD -belangen die gediend moesten worden, waaronder de urgente financiële tekorten. Anderzijds is de conclusie dat het nodig was geweest sterker leiderschap te tonen. $M$ et name uit de resultaten van de enquêtes blijkt immers dat er onder een grote groep actoren, inclusief raadsleden en ambtenaren, een redelijk tot groot draagvlak bestond voor het continueren van de samenwerking met behoud van het toenmalige investeringsbudget (factor belang van determinanten van draagvlak, tabel 10.2). Directie en portefeuillehouders hebben te lang gedraald. D e regie was zoek, de GGD-directie wilde de brede coal itie van $\mathrm{H}$ artslagpartners, de voormalige Stuurgroep, niet inzetten om gemeenten te overtuigen, en uiteindelijk besliste de GGD intern de bezuinigingen meer dan evenredig af te wentelen op de unit gezondheidsbevordering. Eén van de bestuurders concludeerde achteraf dat $\mathrm{H}$ artslag Limburg door bezuinigingen "dubbel gepakt" is. 


\section{Determinanten van draagvlak}

D e invloed van externe factoren, lokale context en verandermanagement wordt conform het W IZ-model zichtbaar in de 'determinanten van het draagvlak'. D eze laten zien dat het merendeel van de respondenten, inclusief de bestuurders, de doelstelling redelijk tot hoog waarderen. Wanneer zij het belang van die samenwerking moeten afzetten tegen andere prioriteiten, blijken portefeuillehouders echter terughoudender te zijn dan de gemiddelde respondent uit de enquêtes, inclusief ambtenaren en raadsleden. $D$ e financiën, met name de dreigende bezuinigingen, lijken het draagvlak bij de bestuurders zwaarder onder druk te zetten. Verder blijkt de win-win-factor, de mate waarin betrokkenen meer voordeel dan nadeel ervaren, in 2003 bij de helft van de respondenten positief uit te vallen; bij gemeenten scoort deze factor wat lager en het aantal negatief gestemden neemt in 2004 toe. In 2004 blijkt de overeenstemming over de regie (factor consensus) afgenomen te zijn; een andere conclusie is dat het urgentiebesef bij portefeuillehouders en GGD -directie tekortschoot (factor sense of urgency).

\section{Uitingsvormen van draagvlak}

O nder de noemer 'uitingsvormen van draagvlak' signaleert bijna de helft van de respondenten in 2004 een dalend onderling vertrouwen, in termen van concurrentiesfeer en eigen gewin. $\mathrm{D}$ e factor tonen van betrokkenheid betreft gebeurtenissen of uitspraken die leiden tot concrete stappen voor de inzet van mensen en middelen; deze factor komt in de feitenbeschrijving meermaals terug. $M$ aar de interpretatie hiervan is dat het ontbreken van tonen van betrokkenheid op de noodzakelijke momenten waarschijnlijk méér zegt over het feitelijke draagvlak dan de gevonden positieve uitingen. $D$ at leidt tot de conclusie dat een gebrek aan urgenti ebesef en van tonen van betrokkenheid op de daartoe noodzakelijke momenten, belangrijke signalen zijn voor een dreigend gebrek aan draagvlak.

\section{Niveau van bestuurlijke verankering}

Aan het eind van de onderzoeksperiode (oktober 2002 - oktober 2005) blijkt dat de samenwerking in aangepaste vorm opgenomen is in gemeentelijke nota's en als product in de reguliere GGD -begroting staat. $\mathrm{H}$ et niveau van bestuurlijke verankering is in diezelfde periode echter met ongeveer de helft gedaald. De forse gemeentelijke bezuiniging leidt uiteindelijk tot de afbraak van de opgebouwde samenwerkingsstructuur op wijk- en gemeenteniveau. Al eerder, namelijk medio 2003, was de samenwerking met huisartsen gestopt. O pmerkelijk genoeg weten GGD en ziekenhuis hun samenwerking wel te continueren. $H$ et deel van de casus dat handelt over de samenwerking tussen GGD en M argraten én tussen GGD en ziekenhuis, laat zien dat bij voldoende invulling van de gemeentelijke regierol in combinatie met verandermanagement er wel degelijk positieve verankeringsresultaten mogelijk zijn. Wel is het zo dat bij de samen- 
werking met het ziekenhuis externe financiering hieraan zeker heeft bijgedragen.

\section{Conclusie uit de casus Hartslag Limburg}

In de analyse is sterk gefocust op het langlopende proces rond het gemeentelijke deel van $\mathrm{H}$ artslag Limburg en de interactie tussen GGD en gemeenten. Er bleek sprake van een ongunstige landelijke context, maar ook van een ongunstige lokale context vanwege gemeentebrede bezuinigingen en een gebrekkige gemeentelijke invulling van de regierol (qua bestuurlijke visie, prioriteitstelling, toekenning van middelen, interne ambtelijke regie en timing). In deze moeilijke situatie schoot het leiderschap van de GGD op onderdelen tekort, maar werd op operationeel niveau adequate actie ontplooid om het draagvlak te bevorderen. $D$ it alles resulteerde in een beperkt en wankel draagvlak onder gemeentelijke bestuurders. D e presentatie van effectcijfers droeg bij aan enkele tussentijdse verankeringssuccessen, maar deze bleken onvoldoende om een blijvend resultaat te bereiken. $U$ iteindelijk leidde dit ertoe dat het niveau van bestuurlijke verankering met de helft daalde, een teleurstellend resultaat.

\subsubsection{Algemene conclusie}

D e centrale vraagstelling van dit onderzoek luidt: $0 p$ welke manier en in welke mate kan verandermanagement vanuit de GGD, gegeven de context van lokale omstandigheden en externe factoren, bijdragen aan bestuurlijke verankering van regi 0 nale samenwerking in de publieke gezondheidszorg?

H ieronder volgt een algemene conclusie. De discussie in paragraaf 11.3 , discussie, gaat in op verschillende aspecten uit die conclusie.

H et antwoord op de vraagstelling luidt dat verandermanagement vanuit de GGD ondanks het gebrek aan landelijke financiering voor lokale preventieprogramma's, kan bijdragen aan bestuurlijke verankering van regionale samenwerking in de publieke gezondheidszorg.

Verankering is te realiseren door, enerzijds, voldoende operationeel verandermanagement dat het draagvlak bevordert via visie, sociaal ondernemerschap, beïnvloedingsstrategieën en netwerkontwikkeling, en, anderzijds, leiderschap dat in staat is om preventie overeind te houden in de belangenstrijd met andere prioriteiten. D e beschikbaarheid van resultaatcijfers vormt een belangrijk maar geen doorslaggevend element binnen het operationele verandermanagement.

D e mate waarin verandermanagement succes kan hebben is mede afhankelijk van de lokale context, met name van de invulling van de gemeentelijke regierol. $D$ ie regierol betreft zowel de bestuurlijke visie, prioriteitstelling en toekenning van middelen, als de interne ambtelijke regie. De regierol houdt verder een 
goede afstemming in van het gemeentelijke besluitvormingsproces met de professionele processen van uitvoering en evaluatieonderzoek.

Verankering van bestuurlijke samenwerking is vooral een kwestie van regie nemen, zowel door de gemeente als door de GGD.

Binnen de publieke gezondheidszorg is deze conclusie extra belangrijk voor de activiteiten op het gebied van de gezondheidsbevordering. $D$ at komt doordat dit taakveld op een aantal punten in de belangenstrijd om middelen zwakker staat dan andere taakvelden van de GGD. Ten eerste zijn de wettelijke eisen ten aanzien van de gezondheidsbevordering minder scherp omschreven dan voor de infectieziektebestrijding en de jeugdgezondheidszorg. Ten tweede zijn resultaten op dit terrein veelal moeilijker aantoonbaar. En ten derde riskeert de gekozen aanpak na enige tijd een daling in de maatschappelijke en politieke prioriteit, omdat resultaten van interventies vaak zo lang op zich laten wachten. M en gaat zich afvragen: 'Werkt het wel?' D ie vraag is legitiem, maar is gemakkelijk te gebruiken als excuus om gezondheidsprogramma's geen kans te geven. Vanuit de zwakke positie van gezondheidsbevordering is het dus praktisch ondoenlijk om zonder steun van de GGD -directie en zonder regie van de gemeente verankering van samenwerking te realiseren.

\subsection{Discussie}

Wat betekent de algemene conclusie nu voor de praktijk van de publieke gezondheidszorg, in het bijzonder de gezondheidsbevordering?

Een centrale conclusie is dat de verankering van succesvolle samenwerking in de publieke gezondheidszorg niet overgelaten mag worden aan het uitvoerend niveau (projectleider en lokale actoren). H oe belangrijk ook de rol van de doelstelling van de samenwerking, de beschikbaarheid van effectieve programma's, de positieve projectresultaten of het draagvlak onder de samenwerkingspartners in het veld, de bestuurlijke verankering is tevens afhankelijk van het leiderschap van de GGD -directie en de regierol van de gemeenten. D eze conclusie betekent voor de praktijk dat er verbetering nodig is in het samenspel van de gemeentelijke regierol, leiderschap en operationeel verandermanagement. We gaan hieronder in op een viertal aspecten: de afstemming van besluitvormings- en evaluatieprocessen, de betrokkenheid bij innovatie, het onderwerp op de politieke agenda houden, en leiderschap en verandermanagement.

\section{Afstemming van besluitvormings- en evaluatieprocessen}

Eerste punt in dit samenspel betreft de afstemming van besuitvormings en evaluati eprocessen. Al vaker is aangetoond dat de politieke besluitvorming voor een 
public health programma begint met een 'window of opportunity' waarin consensus bestaat over de gezamenlijke probleemstelling en de beoogde aanpak tussen beslissers (politiek), probleemhouders (de community, professionals) en probleemoplossers (professionals) (Kingdon, 1995). H ier begint de regierol van de gemeente.

Idealiter dient er bij die start afgesproken te worden hoe resultaten geëvalueerd zullen worden en zullen bijdragen aan besluitvorming over continuering (Saan \& $\mathrm{H}$ aes, 2005). D e praktijk is dat dit nog veel te weinig gebeurt. M eestal bevatten gemeentelijke nota's wel doelen, minder vaak middelen, en zelden is duidelijk of en hoe evaluaties zullen plaatsvinden en welke consequenties deze moeten hebben (Staatstoezicht, 2005). Bovendien zijn doelen veelal niet toetsbaar geformuleerd. D e casus H artslag Limburg demonstreert dat ook aandacht voor afstemming van beleid en onderzoek aan het begin nog geen garantie biedt voor een daadwerkelijke verwezenlijking van die afstemming op termijn. In de casus maakten betrokken partijen bij aanvang de afspraak om bij positieve onderzoeksresultaten de aanpak te continueren. D eze afspraak werd wel in vergaderstukken vastgelegd, maar niet tussen gemeenten en GGD geformaliseerd, noch in raadsbesluiten opgenomen. D aarmee veranderde $\mathrm{H}$ artslag $\mathrm{L}$ imburg van een gemeentelijk programma in een GGD -project. H et risico hiervan is dat na verloop van tijd, wanneer nieuwe wethouders aantreden, de natuurlijke neiging van de wethouder om nieuw beleid te initiëren ten koste gaat van het al lopende project. In de casus werden wethouders wel meteen na de verkiezingen van 2002 geïnformeerd, maar het draagvlak moest opnieuw worden opgebouwd. Bovendien ontbrak het bij de GGD in een cruciale periode van dreigende bezuinigingen aan inzicht in en invloed op het gemeentelijk beleidsproces. H et probleem na een eenmaal gezamenlijk gemaakte start is dus: hoe behoud je het draagvlak voor het project, als jarenlang gewacht moet worden op de resultaten? Een twee ledige oplossing lijkt het beste: zowel 'beter afspreken' als 'beter organiseren dat probleemhouders en probleemoplossers het onderwerp op de politieke agenda kunnen blijven houden'. Dit tweede deel van de oplossing is breder dan alleen de afstemming van besluitvorming en onderzoek; het betreft een tweede discussiepunt in het samenspel tussen gemeente en GGD (zie onder).

$M$ et 'beter afspreken' bedoelen we: formeler vastleggen in de gemeentelijke nota. D ie nota zal dan méér moeten zijn dan de begroting van de GGD, maar een echt gemeentelijk programma, met een lange termijn (meer dan een periode van vier jaar), een visie op de bijdrage van de GGD en andere partners uit het veld, een evaluatieplan en een financieringsparagraaf. $D$ at zal in eerste instantie niet gemakkelijk zijn. Elk nieuw college heeft behoefte aan beleidsvrijheid om het na vier jaar anders te doen dan daarvoor. Er zijn echter veel meer gemeentelijke processen aan te wijzen die jarenlange planning vergen en dus voor langere tijd programmatisch worden vastgelegd. D e conclusie uit dit onderzoek is dat afspra- 
ken voor continuering op lange termijn die niet formeel zijn vastgelegd, bij wisseling van bestuurders een lagere prioriteit dreigen te krijgen. D it is jammer van de al gedane investeringen en opgebouwde ervaringen. W illen gemeenten de regierol adequaat invullen dan moeten ze investeren in een meerjarige programmatische planning en bereid zijn daarover bindende afspraken te maken. In die planning moet rekening gehouden worden met onderzoeksplanning en met formulering van voor de gemeente relevante doelen. D e doelformulering kan dus afwijken van wat professionals als relevant zien. Tegelijkertijd moeten die doelen ook weer niet al te rigide gehanteerd worden; uit onderzoek blijkt dat bijstelling van doelen op basis van tussentijds verworven inzichten evenzeer belangrijk is (Raad voor de Volksgezondheid \& Zorg, 2006; H orstman \& H outepen, 2005). $D$ it is typerend voor gezondheidsprogramma's die zich afspelen in de complexe werkelijkheid van maatschappelijke veranderingsprocessen. Elke implementatie is dan tevens een innovatie. D at wil zeggen: een zoektocht, een ontwikkelingsproces. D it sluit aan bij het volgende punt.

\section{Betrokkenheid bij innovatie}

In het verlengde van de afstemming van besluitvormings- en evaluatieprocessen ligt de betrokkenheid bij innovatie. 0 ok hierbij is een regierol van gemeenten essentieel. Traditioneel wordt het meeste innovatiegeld landelijk verdeeld via professionele kanalen uit de kenniscyclus: aanvragen van universiteiten, overige kennisinstituten en GGD 'en die door ZonM w worden gehonoreerd. H et risico van dit traject is dat men pas aan het eind van de weg, wanneer succesvolle programma's geïmplementeerd kunnen worden, bij gemeenten aanklopt voor financiering. En dan blijkt het vaak moeilijk om hier draagvlak voor te vinden omdat de gemeente weinig prioriteit aan de voorstellen geeft. H et zou daarom beter zijn gemeenten in een vroeger stadium te betrekken bij innovatie in de publieke gezondheidszorg. D it kan bijvoorbeeld door hen een vorm van betrokkenheid te geven bij landelijke innovatiefondsen en bij onderzoek naar de ontwikkeling van intersectoraal gezondheidsbeleid (VN G , 2006b). Een andere mogelijkheid is om cofinanciering door gemeenten voor zowel de ontwikkelingsfase als de implementatiefase vast te leggen bij de toekenning van landelijke financiering. $\mathrm{H}$ et programma Academische Werkplaatsen Publieke Gezondheidszorg van ZonM w betrekt gemeenten al nadrukkelijker bij innovatie.

\section{Hoe kan een onderwerp op de politieke agenda blijven?}

$M$ ogelijk even belangrijk als een betere gemeentelijke regie is zorgen dat het onderwerp publieke gezondheidszorg voldoende op de politieke agenda blijft. D e literatuur benoemt in vier verklaringsmodellen meerdere factoren die daarbij een rol kunnen spelen (de Vries, 2003). D e modellen onderscheiden zich in hun kijk op maatschappelijke problemen en op de mate waarin groepen actoren 
invloed kunnen uitoefenen op de agendavorming. $\mathrm{H}$ et barrièremodel legt bijvoorbeeld de nadruk op de rol van de media als een cruciaal middel om barrières te overwinnen die bestaan tussen achtereenvolgens de bewustwording van een probleem, de plaatsing op de publieke agenda en op de beleids- en besluitvormingsagenda. H oewel de modellen verschillen in de nadruk op de concurrentiestrijd tussen problemen (een strijd die via de media de prioriteit zou bepalen op de publieke en politieke agenda) plaatsen zij alle de actieve rol van 'voorstanders' of pleitbezorgers centraal. G ebruik van de media, met alles wat daarbij komt kijken (gegevens leveren om de omvang van het probleem te onderbouwen, begrijpelijk presenteren, aan- of afwezigheid van emoties, inspelen op actualiteit, de haalbaarheid van de gepresenteerde oplossing; te vergelijken met elementen van operationeel verandermanagement in deze studie) én de actieve inzet van voorstanders, lijken de bepalende veranderbare factoren voor agendavorming. $0 \mathrm{p}$ dit laatste gaan we hier verder in.

$\mathrm{H}$ et meest recente verklaringsmodel, het stromenmodel van $\mathrm{Kingdon}$, is heel expliciet over de rol van de verschillende actoren (Kingdon 1995). Volgens dit model is de keuze voor een beleid niet alleen afhankelijk van de erkenning van het probleem en de ervoor aangereikte oplossing, maar vooral ook van de politieke steun voor die oplossing. Dit laatste vraagt dat probleemhouders (de community, professionals) en probleemoplossers (professionals) met elkaar een coalitie kunnen vormen om de politiek te beïnvloeden (Kingdon, 1995; M cK ee et al., 2000). In de casus $\mathrm{H}$ artslag Limburg is pregnant naar voren gekomen dat dit binnen de huidige structuur van de GGD en problematische opdracht is. Aan de ene kant heeft de GGD, als professioneel instituut, vaak het mandaat van gemeenten om zorg te dragen voor de uitvoerende regie en de samenwerking met actoren uit het veld te coördineren. M aar op het moment dat deze taak botst met het belang van de gemeentelijke bestuurder(s), dus bij besluitvorming over continuering en investering, is er een probleem. $D$ an wreekt zich in veel gevallen dat de directie van de GGD formeel slechts de secretaris is van het bestuur. $D$ ie secretaris wordt geacht te adviseren in plaats van te pleiten (D 213, artikel 19.1 en 20.3). H et bestuur van de GGD zou de belangen van de publieke gezondheid moeten verdedigen bij de gemeentelijke bestuurders, maar beide functies worden uitgeoefend door dezelfde personen. De GGD -bestuurders hebben dus twee petten op: zij moeten zowel de bestuurlijke belangen van de gemeenten als de professionele belangen van de GGD dienen. Dit is niet goed geregeld. D e politiekbestuurlijke neiging om voor de weg van de minste te weerstand te kiezen wint het dan gemakkelijk van de minder aanwezige professionele betrokkenheid. Dit blijkt eens te meer uit de casus $\mathrm{H}$ artslag Limburg. Bovendien komt de GGD directie in een loyaliteitsconflict. Als de directie leiderschap toont, gaat staan voor de professionele zaak en de coalitie organiseert met veldpartijen, zet zij haar eigen bestuur onder druk. D at zullen bestuurders niet altijd kunnen waarderen. 
D e conclusie luidt: als we willen dat de publieke gezondheidszorg beter op de politieke agenda komt te staan, moet de dubbele-pet-constructie voor GGD bestuurders worden afgeschaft. $D$ e publieke gezondheidszorg is erbij gebaat dat de GGD zijn professionele taak zelfstandig kan ontplooien. D ie professionaliteit moet ook tot uiting komen in zijn bestuur. G GD -bestuurders (en de directie) moeten in maatschappelijke en politieke discussies kunnen pleiten en lobbyen voor de zaak, zonder met handen en voeten gebonden te zijn aan de gemeentelijke bestuurders. D e tegenwerping is veelal dat de betrokkenheid van wethouders bij het bestuur van de GGD zou zorgen voor meer politieke steun: de G GD heeft een 'ambassadeur' in het college van $B \& W$. O ok zou gebrek aan vertrouwen van de gemeenten in de GGD een rol spelen (VNG \& GGD N ederland, 2004). D eze argumenten wegen echter niet op tegen het risico van vermindering van steun en inconsistent beleid, zoals dat in dit onderzoek op meerdere punten naar voren is gekomen. $D$ an is cruciaal dat de stem van het professionele veld gehoord wordt en niet wordt belemmerd door belangenverstrengeling. D e lokale publieke gezondheidszorg heeft recht op een positie in het natuurlijke spanningsveld tussen praktijk en politiek die gelijkwaardig is aan de positie van, bijvoorbeeld, welzijnswerk, onderwijs of andere zorginstellingen. In de meeste gemeenten is in die sectoren de scheiding van bestuurlijke verantwoordelijkheden al jaren geleden doorgevoerd. De GGD kan net als andere zorginstellingen, zoals ziekenhuis en verpleeghuis, functioneren binnen allerlei wettelijke kaders en tegelijk met zijn opdrachtgever, de gemeente, onderhandelen over zijn taakinvulling en hierover goedkeuring verkrijgen. Bij een dergelijke onafhankelijke positie past de vorming van een professioneel bestuur met vertegenwoordigers vanuit het maatschappelijk veld. Een vergelijkbare aanbeveling, het opnemen van huisartsen in het GGD -bestuur, is recent nog verwoord in een studie door het Sociaal Cultureel Planbureau (Kooiker \& Van der Velden, 2007). H et principe strookt bovendien met buitenlands onderzoek waaruit blijkt dat een breder 'sense of ownership' van public health issues, los van de overheid, plus de institutionele capaciteit om zelfstandig analyses te maken en issues op de politieke agenda te plaatsen, essentiële factoren zijn voor een goed functionerende publieke gezondheidszorg (M cK ee et al., 2000).

Tot slot: de kern van de hier bepleite scheiding van bestuurlijke verantwoordelijkheden is eerder omschreven als het 'afnemersmodel', waarbij gemeenten zelf de beleidsverantwoordelijkheid nemen en de G GD als zorgaanbieder diensten levert (VN G \& GGD N ederland, 2004). D estijds werd dit model gezien als "een brug te ver", vanwege de introductie van de Wmo en omdat gemeenten en GGD nog niet klaar zouden zijn voor een herziening van hun relatie. Anno 2008 lijken deze argumenten achterhaald. 


\section{Leiderschap en verandermanagement vanuit de GGD}

$G$ egeven de lokale context en de vaak beperkte ambities van gemeenten op het terrein van de publieke gezondheidszorg is leiderschap vanuit de GGD nodig om samenwerking met het veld te ontwikkelen en verankerd te krijgen. Dit vraagt om leiderschap dat stimuleert dat het gezondheidsonderwerp op de politieke agenda blijft staan, urgentiebesef weet te creëren en bestuurders en onafhankelijke organisaties uit het veld weet te overtuigen, en daarmee in de belangenstrijd, waarin prioriteiten afgewogen worden, weet te overwinnen.

Leiderschap dat oog heeft voor het belang niet alleen de gemeentelijke portefeuillehouder voor volksgezondheid als medestander te hebben, maar ook andere leden van het college, bij voorkeur de burgemeester en de wethouder financiën. Dit type leiderschap sluit het meest aan bij de literatuur over transformationeel leiderschap (Burns, 1978; Yukl, 1998). D e term transformationeel leiderschap verwijst naar het kunnen 'transformeren' c.q. inspireren en motiveren van derden. Succesvol transformationeel leiderschap wordt daarbij geassocieerd met positieve kwaliteiten als veranderingsgerichtheid, luisteren naar noden van mensen, in staat zijn kernwaarden te formuleren en te demonstreren in voorbeeldge drag, en een zorgvuldige probleemanalyse kunnen maken (Tichy \& D evanna, 1986).

D e vraag is echter in hoeverre het reëel is om te verwachten dat alle directeuren van GGD'en als transformationele leider kunnen of willen optreden. Een andere vraag is hoe dit transformationele leiderschap te ontwikkelen, te stimuleren en te ondersteunen is. D it vergt nader onderzoek. H et ligt voor de hand dat de branchevereniging, GGD N ederland, hierin een rol kan spelen.

In deze studie is het leiderschap vanuit de directie van de GGD onderzocht. Toch verdient ook de ontwikkeling van leiderschapskwaliteiten bij managers en projectleiders aandacht. Juist op deze niveaus nemen mensen vaak goede initiatieven, die passen bij de uitvoerende regierol van de GGD. Kennis op het niveau van operationeel verandermanagement kan bijdragen aan een efficiënte samenwerking tussen directie en management van de GGD en helpen bij het creëren van draagvlak bij gemeenten en veldpartijen, zowel ambtelijk, professioneel als bestuurlijk. Uit de casus van $\mathrm{H}$ artslag Limburg valt te leren dat degenen die het operationele verandermanagement uitvoeren niet alleen moeten letten op de positieve stappen die gezet worden, maar ook alert moeten blijven op gebrek aan urgentiebesef en gebrekkige blijken van betrokkenheid van bestuurders en directie. $0 p$ die momenten moeten betrokkenen afwegen of verdere actie nog mogelijk is of dat ze lagere prioriteitstelling moeten accepteren. Tot slot nog een opmerking over het belang van de beschikbaarheid van effectcijfers als steun voor de overtuigingskracht van verandermanagement. U it de casus $\mathrm{H}$ artslag Limburg is naar voren gekomen dat gunstige effectcijfers hieraan wel degelijk een bijdrage kunnen leveren. Wetenschappelijk verantwoorde effect- 
cijfers genereren is echter voor veel projecten en programma's op het terrein van de gezondheidsbevordering en preventie onhaalbaar vanwege de kosten.

Bovendien duurt het vele jaren voordat meetbare effecten beschikbaar komen. D at schept een dilemma: effectcijfers zijn nodig maar hierop te vroeg inzetten kan leiden tot teleurstellende resultaten en verlies van draagvlak. Dit dilemma is op twee manieren op te lossen. Ten eerste kan dit via de ontwikkeling van intermediaire procesindicatoren die op betrouwbare wijze zichtbaar kunnen maken of het gezondheidsprogramma op de goede weg zit. Een set landelijk erkende procesindicatoren zal een belangrijk hulpmiddel zijn voor het operationele verandermanagement om verantwoording af te leggen aan het bestuurlijk niveau. Ten tweede is het bij schaarse middelen beter om te focussen op minder, maar wel beter opgezette en langdurige programma's, omdat die voortgangscijfers en op termijn resultaatcijfers kunnen laten zien. $\mathrm{H}$ et huidige programma Academische Werkplaatsen Publieke G ezondheidszorg biedt daarvoor een zeer bruikbaar kader.

\subsection{Beschouwing}

Ter beantwoording van de centrale vraagstelling van dit onderzoek is een 'embedded' single case study gedaan naar de casus $\mathrm{H}$ artslag Limburg. In het kader hiervan zijn in de periode oktober 2002 - oktober 2005 vooral kwalitatieve en deels kwantitatieve data verzameld. Voor de ordening van data, de analyse en het zoeken naar verklaringen is het W IZ-model gebruikt. D it model is op basis van tussentijds vergaarde inzichten op onderdelen bijgesteld (zie 3.5 en 7.6). D e veronderstelling van de gekozen onderzoeksopzet is dat analyse op meerdere niveaus ('embedded'), met triangulatie van de verzamelde data, inzichten genereert die leiden tot het beantwoorden van de centrale vraagstelling. $D$ e vraag is in hoeverre de in het onderzoek gevonden resultaten en conclusies valide en betrouwbaar zijn.

Zoals wel vaker bij kwalitatief onderzoek het geval is, schuilt in de kracht van de onderzoeksopzet tevens de zwakte. Beide worden hier besproken.

Een sterk punt in dit onderzoek was ongetwijfeld de mogelijkheid om veel verschillend materiaal te verzamelen. $M$ et name de feitenverzameling is als bron bijzonder waardevol gebleken. Kennis van belangrijke gebeurtenissen en van bestaande documenten kon worden verzameld omdat de onderzoeker tijdens de eerste helft van de dataverzamelingsfase bij het operationele verandermanagement betrokken was. D e meerwaarde van de feitenverzameling is verder gelegen in de triangulatie met data uit interviews en enquêtes. Een belangrijk deel van de inzichten uit dit onderzoek komt voort uit die onderlinge vergelijking. D eze 
biedt namelijk inzicht in de discrepanties tussen wat mensen zeggen en doen. Een mogelijk zwak punt is dat er sprake kan zijn geweest van selectiebias bij het verzamelen van de data. D oor de betrokkenheid van de onderzoeker bij de GGD zijn mogelijk relevante data van bijvoorbeeld gemeenten gemist, juist vanwege de verwevenheid van belangen. $0 \mathrm{~m}$ dit risico zo goed mogelijk te ondervangen zijn de vragenlijsten afgedrukt op briefpapier van de U M en heeft een onafhankelijke researchassistent de interviews afgenomen. Verder is de feitenbeschrijving ter validering voorgelegd aan een panel van de GGD. Ten slotte is de feitenbeschrijving ook voorgelegd aan een panel van externe experts. D e uitkomst van deze laatste stap was dat de beschrijving op basis van het gevonden materiaal voldoende rijk en overtuigend was om de belangenstrijd en irrationele dynamiek zichtbaar te maken. Dit is naar ons oordeel in de voorgaande hoofdstukken voldoende helder gelukt. M ocht diens subjectiviteit een rol hebben gespeeld bij selectiebias en data-analyse, dan is het hier van belang te melden dat de onderzoeker in de twintigste onderzoeksmaand, per 1 mei 2004, uit de regio is vertrokken en sinds die tijd niet meer bij de GGD werkt.

Een tweede beperking van dit onderzoek heeft betrekking op de validiteit en betrouwbaarheid van het ordeningskader: het W IZ-model. D it model verschafte de noodzakelijke logische ordening van data. $D$ e validiteit betreft de mate waarin de gevonden data binnen de juiste dimensie en factor kunnen worden geplaatst. D e betrouwbaarheid betreft de mate waarin het ordenen herhaal baar is door anderen met dezelfde resultaten als gevolg. Beide vereisten zijn sterk afhankelijk van de scherpte van de definiëring van dimensies en factoren van het model en van de mate waarin deze definiëring aansluit bij de werkelijkheid. $0 \mathrm{~m}$ de validiteit en betrouwbaarheid te testen en te verbeteren is in dit onderzoek gebruik gemaakt van twee strategieën. D e operationalisering, dat wil zeggen de toekenning van een gebeurtenis aan een dimensie en een factor uit het W IZmodel (hierna labeling genoemd), is getest met behulp van twee onafhankelijke assessors. Een panel van drie onafhankelijke experts is gevraagd een oordeel te geven over zowel de validiteit van het model als de toegepaste labeling.

Bij de labeling van gebeurtenissen en meningen uit interviews door de assessors bleek een verschil in niveau van betrouwbaarheid tussen de assessors, afhankelijk van hun inhoudelijke bekendheid met het materiaal (gebeurtenissen in de publieke gezondheidszorg, kennis van organisaties en actoren) en de ervaring in het werken met labeling via definities. Geconcludeerd is dat deze methode bij het hanteren van gelijke definities door assessors van een vergelijkbaar kennisniveau leidt tot vergelijkbare uitkomsten. Een zeker niveau van onscherpte van definiëring blijft echter onvermijdelijk. $D$ it geldt in de eerste plaats voor gebeurtenissen die in meer dan één factor van het model geplaatst kunnen worden. In dit onderzoek is dat opgelost door de 'dubbelingen' zichtbaar te maken bij de presentatie van de aantallen gebeurtenissen in de feitenbeschrijving, en te bena- 
drukken dat uit deze aantallen geen kwantitatieve conclusies getrokken kunnen worden. In de tweede plaats is gevonden dat er een onscherpte van definiëring mogelijk is die te maken heeft met de negatieve kant van een factor. Dit geldt onder andere het definiëren van de factor 'tonen van betrokkenheid'. Belangrijk maar lastig blijkt het definiëren en meten van de negatieve kant van deze factor: het ontbreken van tonen van betrokkenheid op de noodzakelijke momenten. De negatieve kant van de factor zegt waarschijnlijk meer over het feitelijke draagvlak dan de positieve. Dit geldt ook voor leiderschap en urgentiebesef. In dit onderzoek is in de loop van de analyse het feitenmateriaal opnieuw gescreend, om de gebeurtenissen te turven waarbij sprake was van dit ontbreken van tonen van betrokkenheid, respectievelijk leiderschap en urgentiebesef.

$U$ it de raadpleging van het expertpanel kwam naar voren dat de validiteit van het model op drie onderdelen (belangenstrijd, leiderschap en urgentiebesef) verbeterd kon worden. D eze adviezen zijn doorgevoerd en in een latere fase van de analyse is het model verder aangevuld met de factor 'regierol gemeenten'. Al deze aanvullingen zijn vervolgens betrokken bij de analyses. H et was natuurlijk idealer geweest als deze factoren ook in enquêtes en interviews hadden kunnen worden verwerkt. Tegelijkertijd hoort het verwerven van voortschrijdend inzicht ook wel bij dit type kwalitatief onderzoek. $\mathrm{H}$ ieruit is de algemene les te trekken dat dit type onderzoeksmodel telkens zo nauwkeurig mogelijk toegesneden moet worden op de onderzoekssetting, in dit geval de publieke gezondheidszorg. Kenmerkend voor deze setting bleek te zijn dat leiderschap een rol speelt op meer niveaus dan aanvankelijk op basis van het begrip entrepreneurschap (Kingdon, 1995) werden onderscheiden: behalve op operationeel (G GD -projectleiding) namelijk ook op niveau van de GGD -directie en op gemeentelijk niveau (regierol). Vervolgonderzoek zou zich zowel kunnen richten op een meer theoretische onderbouwing van deze verschillende vormen van leiderschap als op de condities waaronder deze niveaus optimaal in samenhang kunnen functioneren. In dergelijk onderzoek zou met name gekeken kunnen worden naar de positie van de portefeuillehouder volksgezondheid in het college van B\&W. Verder bleek het kunnen presenteren van voortgangs- en effectcijfers, c.q. van 'evidence', een element dat iets te veel verborgen zat in de factor beïnvloedingsstrategieën. In vervolgonderzoek zou dit als een aparte factor binnen het operationele verandermanagement opgenomen moeten worden.

Samenvattend kan de conclusie luiden dat de gehanteerde methode, inclusief de genoemde aanvullingen, voldoende valide en betrouwbaar is om de beschreven resultaten en conclusies te rechtvaardigen. 


\title{
11.5 Aanbevelingen
}

D e bevindingen uit de voorgaande paragrafen liggen ten grondslag aan de volgende vijf aanbevelingen.

\begin{abstract}
Aanbeveling 1
D e gemeente kan haar regierol verbeteren door afspraken te maken met de GGD over de continuering op lange termijn van breed opgezette programma's voor gezondheidsbevordering en preventie. Breed opgezet betekent hier: met bijdragen van externe partijen, met een koppeling aan welzijns-, armoede- en jeugdbeleid en een bijpassende programmabegroting. D eze afspraken moeten formeel worden vastgelegd in raadsbesluiten; de planning van bestuurlijke besluitvorming over continuering moet afgestemd worden op de planning van evaluatief onderzoek en rekening houden met de langdurige aard die dit type ontwikkelingsprocessen nu eenmaal kenmerkt.
\end{abstract}

\section{Aanbeveling 2}

Gemeenten dienen zelf een rol te hebben in de besluitvorming bij het toekennen van subsidies voor innovaties in de publieke gezondheidszorg, met name bij die innovaties waarvan bij succes te verwachten is dat de gemeenten de kosten voor implementatie moeten dragen. $\mathrm{H}$ et programma Academische Werkplaatsen Publieke Gezondheidszorg van ZonM w voorziet hierin in zekere mate en dient bij positieve evaluatie daarom zeker gecontinueerd te worden.

\begin{abstract}
Aanbeveling 3
$0 \mathrm{~m}$ de publieke gezondheidszorg voldoende hoog op de lokale politieke agenda te krijgen en te houden, is het belangrijk dat de GGD in samenspraak met andere partijen in het veld, zoals huisartsen, voor dit onderwerp een voldoende sterk pleidooi kan houden. O $\mathrm{m}$ die reden moet het bestuur van de G GD bestaan uit vertegenwoordigers die zowel voldoende professionele kennis hebben als een onafhankelijke positie innemen tegenover van het gemeentelijke bestuur. D e dubbele-pet-constructie voor G GD -bestuurders moet worden afgeschaft. Verder is te overwegen om de regionale ondersteuningsstructuur voor de eerste lijn te koppelen aan de GGD .
\end{abstract}

\section{Aanbeveling 4}

$0 \mathrm{~m}$ de publieke gezondheidszorg voldoende hoog op de lokale politieke agenda te krijgen en te houden, is het belangrijk dat het operationele verandermanagement vanuit de GGD adequate voortgangs- en effectcijfers kan genereren. G ezien de noodzaak om zich voor het terrein van gezondheidsbevordering primair te baseren op voortgangscijfers, zou prioriteit gegeven moeten worden aan 
de ontwikkeling van een landelijk erkende set procesindicatoren voor gezondheidsbevordering.

\begin{abstract}
Aanbeveling 5
D e ontwikkeling van de publieke gezondheidszorg vraagt bij de directie van de GGD om nieuw leiderschap. D it onderzoek geeft aanwijzingen dat het accent moet liggen op transformationeel in plaats van traditioneel leiderschap. $\mathrm{N}$ ader onderzoek is gewenst om te kunnen bepalen op welke manier het benodigde leiderschap te ontwikkelen en te ondersteunen is. D it onderzoek zou ook betrekking moeten hebben op de rol van leiderschap op operationeel niveau en op niveau van de gemeentelijke regierol.
\end{abstract}




\section{Nawoord}

"'G elukkige gezinnen zijn allemaal hetzelfde; ieder ongelukkig gezin is ongelukkig op zijn eigen manier'. M et die beroemde openingszin uit Anna Karenina bedoelde Tolstoj dat een gelukkig huwelijk in een groot aantal opzichten moet slagen: seksuele aantrekkingskracht, eensgezindheid over geldzaken, opvoeding van de kinderen, godsdienst, schoonfamilie en andere belangrijke zaken. Als het met een van deze wezenlijke aspecten niet goed zit, kan dat een huwelijk de nek omdraaien, ook als het aan alle andere voorwaarden voor geluk voldoet." (D iamond, 2006)

$N$ et zoals het huwelijk aan veel voorwaarden moet beantwoorden om het een duurzame kans van slagen te geven, zo moet ook aan vele factoren zijn voldaan om een brede en vernieuwende aanpak als die van $\mathrm{H}$ artslag Limburg bestuurlijk te verankeren. Uit dit onderzoek blijkt hoe complex en soms irrationed de werkelijkheid kan zijn. O ok een gedegen onderzochte innovatie met veel goede elementen in zich kan stranden.

Tegelijkertijd biedt dit onderzoek kansen voor de toekomst. Als de lessen en aanbevelingen in deze publicatie daadwerkelijk bijdragen aan een beter inzicht in mogelijkheden voor innovatie in de public health, dan heeft dit onderzoek zijn verwachtingen waargemaakt. 


\section{Samenvatting}

D it proefschrift behandelt de samenwerking tussen organisaties die bijdragen aan de publieke gezondheidszorg en de complexe wijze waarop die samenwerking bij innovatieve projecten gecontinueerd of 'verankerd' kan worden via besluitvorming op bestuurlijk niveau.

H oofdstuk 1 bevat de probleemstelling. Gezondheid en ook de publieke gezondheidszorg winnen aan belang. O p lokaal niveau zijn gemeenten en de GGD be langrijke spelers, met name op het terrein van gezondheidsbevordering.

Bevordering van gezond gedrag vraagt om duurzame samenwerking tussen deze en andere preventiespelers; dat stelt de betrokken partijen voor een belangrijke uitdaging. Kenmerkend voor de N ederlandse situatie is de wettelijke rol van de gemeenten en de functie van de GGD als regionale professionele organisatie ten dienste van de gemeenten. D oor zijn professionele positie is de GGD bij uitstek aangewezen een rol te spelen als makelaar om regionale en lokale samenwerking te realiseren. D e wettelijke bevoegdheden om die rol te vervullen zijn echter beperkt, en de bestuurlijke verantwoordelijkheid ligt bij gemeenten. In dit spanningsveld is kennis nodig over hoe verankering van samenwerking in de praktijk verloopt, welke factoren daarbij een rol spelen en hoe die factoren te bënvloeden zijn.

De literatuur op dit gebied is nog schaars. $0 \mathrm{~m}$ nieuwe kennis te genereren is het belangrijk de ervaringen van voorbeeldprojecten te benutten. Eén zo'n voorbeeldproject is het project $\mathrm{H}$ artslag Limburg uit de regio Zuidelijk Zuid-Limburg ( $M$ aastricht en omliggende gemeenten). In deze regio is van 1998 tot en met 2004 een intensieve samenwerking gereal iseerd tussen de GGD, gemeenten, huisartsen, ziekenhuis, de universiteit (UM ) en andere lokale partners, met als doelen hartvaatziekten te verminderen en een blijvende vernieuwing in de samenwerking te realiseren. M edio 2002 gaven alle lokale partners aan de bestaande samenwerking in principe te willen continueren. M ede gezien het evaluatieonderzoek dat al ter plaatse liep naar uitvoeringsprocessen, effecten en kosteneffectiviteit, bood deze casus een uitgelezen kans om processen op bestuurlijk niveau te onderzoeken. De centrale vraagstelling van dit onderzoek is als volgt geformuleerd: ' $O \mathrm{p}$ welke manier en in welke mate kan verandermanagement vanuit de GGD, gegeven de context van lokale omstandigheden en externe factoren, bijdragen aan bestuurlijke verankering van regionale samenwerking in de publikke gezondheidszorg?'

H oofdstuk 2 gaat over de opbouw van $\mathrm{H}$ artslag Limburg als model project in de periode van 1994 tot 1998. Uitgangspunt bij de start van het project is dat zowel de lokale bevolking als de aanwezige zorgverleners en instellingen worden betrokken bij gezondheidsbevorderende acties en werkwijzen. D it resulteert in twee deel- 
projecten: een gemeentelijk - of 'community'-project, waarin GGD, gemeenten, welzijnswerk en lokale organisaties samenwerken om een gezonde leefstijl te bevorderen, en een zogenoemd hoogrisico-project waarin GGD, huisartsen en het ziekenhuis samenwerken ter verbetering van de begeleiding van patiënten met een hoog risico op hartvaatziekte. In de ruim drie jaar durende opbouwfase worden stapsgewijs bijdragen vanuit onderzoek, praktijk en beleid aan elkaar gesmeed. D e kenmerkende elementen van de organisatiestructuur en de factoren die de opbouw van de samenwerking hebben bevorderd dan wel belemmerd, komen aan de orde. D e conclusie is dat in de casus de meedenkende en stimulerende rol van een hoofdsponsor, lokale politieke betrokkenheid, een positief investeringsklimaat, stapsgewijze opbouw met partners die al langere tijd samenwerken, en sociaal ondernemerschap, de totstandkoming van samenwerking hebben bevorderd. Reflectie op deze factoren, plus de ervaringen die in de loop der jaren het project zijn opgedaan, leidden tot de ambitie de beoogde verankering van de samenwerking onderzoekbaar te maken.

H oofdstuk 3 start met de beschrijving van het theoretisch model. D it zogenoemde 'W IZ'-model is eerder door de capaciteitsgroep Beleid, Economie \& O rganisatie van de Zorg van de UM ontwikkeld en aangepast aan de setting van het be stuurlijke niveau van de publieke gezondheidszorg. H et model onderscheidt vier dimensies of clusters van factoren, die van invloed zijn op de bestuurlijke verankering van samenwerking. Verandermanagement (1), onder andere bestaand uit visie, sociaal ondernemerschap en beïnvloedingsstrategieën, moet leiden tot de gewenste bestuurlijke verankering van samenwerking, maar wordt beïnvloed door externe factoren (2), de lokale context (3) en de mate van draagvlak (4). D e mate van bestuurlijke verankering wordt bepaald aan de hand van vier aspecten: formalisatiegraad, duurzaamheid, inzet van mensen en middelen, en reikwijdte. Aan de hand van dit model is de centrale vraagstelling uitgewerkt in deelvragen. D eze deelvragen betreffen de resultaten per dimensie en de relatie tussen de dimensies, zoals de vraag in hoeverre de uitgevoerde verandermanagement-acties effect hebben op het draagvlak en de bestuurlijke verankering. Validering met behulp van een expertpanel heeft geleid tot een verrijking van het model, waarbij het accent meer kwam te liggen op de belangenstrijd tussen actoren en de gemeentelijke regierol als onderdeel van de dimensie lokale context, en de rol van leiderschap als onderdeel van verandermanagement.

H ierna komt de onderzoeksmethode aan de orde. D eze heeft bestaan uit een zogenoemde 'embedded' single case study naar de casus $\mathrm{H}$ artslag Limburg over de periode oktober 2002 tot oktober 2005. D ataverzameling heeft plaatsgevonden door documentstudie en door twee dataverzamelingsrondes met schriftelijke enquêtes en individuele interviews met actoren. $D$ eze rondes vonden plaats in de loop van 2003 en 2004. De actoren in dit onderzoek zijn de portefeuillehouders 
volksgezondheid van de vijf gemeenten in de regio $M$ aastricht, leden van gemeentelijke raadscommissies, ambtenaren volksgezondheid, directie, staf, middelmanagement en de projectleider $\mathrm{H}$ artslag Limburg van de GGD, directie en middelmanagement van het regionale welzijnswerk, participerende huisartsen in de regio, de directie van het azM , het management van de afdeling $\mathrm{C}$ ardiologie en het latere $\mathrm{H}$ art-Vaatcentrum i.o. van het azM en de contactpersoon van de zorgverzekeraar. Eerste stap in de analyse was het opstellen van een tabelvormige feitenbeschrijving vanuit de documentstudie, waarbij data chronologisch en op geleide van het WIZ-model zijn geordend. D e feitelijke analyse van de data vond plaats door middel van een zogenoemde tijdreeksanalyse, waarbij de data uit de drie bronnen - feitenbeschrijving, enquêtes en interviews - onderling werden vergele ken (triangulatie).

H oofdstuk 4 biedt een overzicht van de belangrijkste resultaten uit de feitenbeschrijving: de mate van bestuurlijke verankering ten tijde van begin- en eindmeting (paragraaf 4.2) en een chronologische verslag van de gebeurtenissen die zich in de tussenliggende tijd afspeelden (paragraaf 4.3). D e bereikte bestuurlijke veranke ring in 2005 blijkt en grillig patroon te vertonen. In de samenwerking tussen de GGD en gemeenten is er vooruitgang geboekt op twee van de vier aspecten, namelijk formalisatiegraad en duurzaamheid. $\mathrm{H}$ artslag Limburg is omgevormd naar een tweetal producten die opgenomen zijn in het basispakket van de GGD. D it houdt in dat alle gemeenten dit pakket standaard afnemen. $0 p$ de andere twee aspecten, inzet van middelen en reikwijdte echter, is sprake van een duidelijke afname van de samenwerking. D oor forse krimp van het budget is de samenwerkingsstructuur met inzet van ambtenaren en lokale werkgroepen afgebroken. H et niveau van de samenwerking is daardoor ongeveer met de helft gedaald.

0 pmerkelijk is dus dat opname van $\mathrm{H}$ artslag Limburg in gemeentelijke nota's niet heeft geleid tot het beoogde niveau van bestuurlijke verankering. D aarnaast is mede door het ontbreken van structurele financiering - de samenwerking met de huisartsen beëindigd, terwijl de samenwerking met het ziekenhuis op ongeveer gelijk niveau voor de duur van tweeënhalf jaar wordt gecontinueerd. $\mathrm{H}$ et chronologische verslag biedt vervolgens een eerste, ingekorte, blik op de ontwikkelingen in de periode 2002 tot en met 2005, op basis van de feitenbeschrijving. $\mathrm{H}$ ieruit blijkt dat de meeste gebeurtenissen plaatsvonden bij het gemeentelijke deel van $\mathrm{H}$ artslag Limburg. D e verdere analyse betreft daarom grotendeels de samenwerking tussen de GGD en de gemeenten; het perspectief van de samenwerking tussen de GGD, huisartsen en academisch ziekenhuis wordt summier behandeld. H oofdstuk 4 besluit met een voorlopige opsomming van de factoren die invloed hebben gehad op het eindresultaat wat betreft de bestuurlijke verankering: landelijk de bezuiniging op het gemeentefonds en lokaal een stroeve relatie tussen de GGD en gemeenten, financiële tegenvallers, het fusietraject van de Zuid- 
Limburgse GGD 'en en mogelijk tekortschieten van het verandermanagement. In de latere hoofdstukken volgt een diepgaande analyse aan de hand van de verschillende dimensies van het WIZ-model.

H oofdstuk 5 biedt een analyse van de dimensie externe factoren van het W IZmodel. Paragraaf 5.2 behandelt de invloed van het landelijke beleid, en paragraaf 5.3 de opstelling van landelijke financiers. G econcludeerd wordt dat het landelijke beleid nieuwe verplichtingen en richtlijnen schept voor professionals en bestuurders op lokaal niveau, zonder dat er duidelijkheid is over adequate financiering. G evolg is dat landelijke organisaties (V N G, GGD N ederland) en het Rijk elkaar aanspreken: de hete aardappel wordt heen en weer geschoven. Toen deze discussie in het begin van 2003 nog liep, kortte het Rijk ook nog eens flink op het gemeentefonds. Bij lokale bestuurders roept deze ontwikkeling een breed gedeelde reactie op: de Wet Collectieve Preventie Volksgezondheid en de preventienota van het ministerie van VW S wil men best serieus nemen, maar zonder extra geld voor gezondheidsbevordering, en helemaal bij extra generieke bezuinigingen, acht men zich niet in staat een vernieuwende aanpak te implementeren. Een soortgelijke ontwikkeling doet zich voor in de samenwerking van de GGD met huisartsen en het zie kenhuis: landelijk ontbreekt er duidelijkheid over financiering en ook de zorgverzekeraar laat weten niet langer te beschikken over additionele middelen voor preventie. $\mathrm{H}$ et klimaat voor bestuurlijke verankering van samenwerking rondom $\mathrm{H}$ artslag Limburg komt door deze externe factoren vanaf begin 2003 flink onder druk te staan.

H oofdstuk 6 biedt een analyse van de dimensie lokale context. D rie paragrafen be handelen de afzonderlijke factoren binnen deze dimensie. Paragraaf 6.2 laat zien dat er in de bestaande samenwerkingsrelaties tussen GGD en gemeenten sprake is geweest van een "stroeve relatie". Paragraaf 6.3 beschrijft hoe drie kenmerken van bedrijfsvoering een belemmerende invloed hebben uitgeoefend op de verankering van het community-deel van $\mathrm{H}$ artslag Limburg (samenwerking gemeenten, G GD en welzijnswerk): gebrek aan financiële transparantie, een verschil in visie op de eindigheid van projecten en de fusie tussen de drie Zuid-Limburgse G GD 'en. In paragraaf 6.4 komt naar voren dat GGD en gemeenten in de samenwerking op vijf thema's belangenstrijd voeren: concurrentie om beleidsprioriteit binnen de GGD -taken, 'investeren of bezuinigen', 'welzijn òf gezondheid', 'lokaal of regionaal' en 'de dubbele pet' van de wethouder die tegelijk GGD-bestuurder is. Die belangenstrijd leidt er onder andere toe dat investeringen in innovatie uitblijven. Als grootste gemene deler voor de vijf belangenstrijdthema's is een gebrekkige regierol van gemeenten aan te wijzen. D e drie factoren samenvattend luidt de conclusie dat de dimensie 'lokale context' ongunstig is geweest voor de bestuurlijke verankering van het community-deel van $\mathrm{H}$ artslag Limburg. D e zich opstapelende 
belemmeringen, bijna allemaal samenhangend met gebrek aan geld, spelen zowel in 2003 als in 2004, waardoor de druk in deze jaren alleen maar is toegenomen. D e aard van de lokale context, samen met de in hoofdstuk 5 beschreven aard van de externe factoren, laat zien dat het G GD -verandermanagement in een ongunstig klimaat heeft moeten opereren.

H oofdstuk 7 gaat nader in op het definiëren van de begrippen regierol gemeenten, leiderschap en verandermanagement. $D$ it is nodig omdat de conclusie van hoofdstuk 6 duidt op een gebrekkige regierol door gemeenten. Analyse van de dimensie verandermanagement (vanuit de GGD) en de factor leiderschap daarbinnen, kan alleen plaatsvinden wanneer helder is hoe deze twee zich verhouden tot de gemeentelijke regierol. Paragraaf 7.2 geeft een beknopt overzicht van de verschillende theoretische visies op het begrip le derschap. D it leidt in paragraaf 7.3 tot de volgende algemene definitie van dit begrip: leiderschap is een wederzijds beïnvloedende relatie tussen een leider en zijn volgers, gericht op het bereiken van tastbare resultaten die passen binnen de gedeelde gemeen schappelijke doelen; gebrek aan leiderschap wordt gekenmerkt door het vermijden van actie en besluitvorming, het negeren van verantwoordelijkheid en het ongebruikt laten van autoriteit.

D eze definitie vormt in paragraaf 7.4 het vertrekpunt voor een definitie van het begrip regierol van gemeenten als een bijzondere vorm van sturen die is gericht op de afstemming van actoren, hun doelen en handelingen tot een meer samenhangend geheel, met het oog op een bepaald resultaat. D eze regievoering vereist een duidelijke gemeentelijke visie, die vertaald wordt in een politiek-bestuurlijke en ambtelijke prioriteitstelling, evenals het vaststellen van de daarvoor benodigde en beschikbare gemeentelijke middelen. D aarentegen wordt een gebrekkige regierol gekenmerkt door het vermijden van besluitvorming over politiek-bestuurlijke en ambtelijke prioriteiten, het negeren van verantwoordelijkheid voor het vaststellen van benodigde middelen en het ongebruikt laten van autoriteit. $H$ et uitvoerende deel van de regierol heeft de gemeente grotendeels ondergebracht bij de GGD . In paragraaf 7.5 volgt een precisering van de begrippen verandermanagement en leiderschap vanuit de GGD. Kern van de gekozen definitie voor leiderschap vanuit de GGD is de focus op de strategische rol van de directeur van de GGD bij het formuleren van (uitvoerende) doelen en de mate van inzet van de eigen autoriteit om die doelen te bereiken. Paragraaf 7.6 sluit af met een aanpassing van het WIZ-model waarin de factor regierol gemeenten is toegevoegd aan de dimensie lokale context (figuur 7.1).

H oofdstuk 8 behandelt de verandermanagement-acties (kortweg: veranderacties) die vanuit de GGD zijn ondernomen. Binnen de dimensie zijn vijf factoren onderscheiden: visie, sociaal ondernemerschap, bënvloedingsstrategieen, netwerkont- 
wikkeling en leiderschap. D e eerste vier factoren worden samengevat onder de noemer operationed verandermanagement. D e factor leiderschap heeft specifiek betrekking op de rol van de directeur als actor. Paragraaf 8.2 geeft een overzicht uit de feitenbeschrijving van de aantallen veranderacties per factor, als opmaat voor 8.3. Paragraaf 8.3 brengt hierin meer betekenis aan door een chronologische beschrijving van de belangrijkste veranderacties per jaartal. In deze paragraaf wordt de tijdreeksanalyse gecompleteerd door triangulatie met data uit interviews en enquêtes; aandachtspunt bij deze triangulatie is voorts in hoeverre de veranderacties effect sorteerden op draagvlak en verankering. Paragraaf 8.4 laat zien dat er een vergelijking mogelijk is tussen drie (deel)casussen binnen de casus $\mathrm{H}$ artslag Limburg: het traject tussen G GD en gemeente $M$ aastricht als voorbeeld van tekortschieten van verandermanagement en leiderschap, en de casus $M$ argraten en de casus azM als geslaagde voorbeelden. Een belangrijk deel van de veranderacties van de GGD heeft een gunstig effect gehad op het draagvlak voor verankering, met name in het begin van het verankeringstraject in de eerste helft van 2003. Dit leidde tot opname van $\mathrm{H}$ artslag L imburg in gemeentelijke nota's en in het beleid van het azM . Vanaf medio 2003 echter blijkt dat de acties vanuit de GGD onvoldoende zijn en het draagvlak nog wankel is. $D$ an blijkt dat het verandermanagement geen grip heeft op de plannen van de gemeente $M$ aastricht, en tekortschiet op momenten waarop het nodig was geweest gemeenten te confronteren met eerdere afspraken. Kansen voor coalitievorming en het tonen van leiderschap blijven onbenut. 0 ndanks de opgel egde bezuinigingen accepteert de directeur van de GGD de opdracht van de gemeenten om $\mathrm{H}$ artslag Limburg te continueren. O p 15 april 2004 bericht de Volkskrant op de voorpagina over de positieve evaluatiecijfers die diezelfde ochtend op het N ationale Congres Volksgezondheid te Rotterdam door RIV M en GGD worden gepresenteerd. D eze opvallende veranderactie blijkt nog niet doorslaggevend. Wel blijkt dat de aanpak in $\mathrm{M}$ argraten effectief is dankzij de combinatie met een gunstige lokale context (regierol portefeuillehouder en timing). D eze gunstige combinatie ontbreekt in $\mathrm{M}$ aastricht, waar de resultaten te laat komen om de bezuinigingen terug te draaien. In de samenwerking met het azM heeft de directie van het ziekenhuis een actieve regierol en is er sprake van additionele externe financiering. H et contrast in de (deel)casussen laat zien dat als sterk leiderschap vanuit de GGD ontbreekt, de kans groot is dat het verankeringsresultaat mager is.

H oofdstuk 9 belicht de regierol van de gemeenten in de casus. Triangulatie van data laat zien dat die regierol op een reeks van cruciale onderdelen tekort schoot. D e gemeentelijke visie, vastgelegd in de nota lokaal gezondheidsbeleid, wordt niet vertaald in een prioriteitstelling; eerdere afspraken met andere actoren worden niet gehonoreerd; afstemming in de tijd met lopend onderzoek wordt be- 
loofd maar niet waargemaakt; de interne regie schiet tekort; en benodigde middelen worden wegbezuinigd, in plaats van toegekend onder twee verschillende noemers (bij het welzijnswerk en bij de GGD ). Dit tekort aan regie speelt vooral in de dominante gemeente $M$ aastricht, maar uiteindelijk heeft de $M$ aastrichtse bezuiniging ook consequenties voor de andere portefeuillehouders. D e andere gemeenten weigeren namelijk om naar rato méér bij te dragen dan $\mathrm{M}$ aastricht (regionale belangenstrijd). In interviews bevestigen enkele portefeuille-houders dat gemeenten "nog in die regierol moeten groeien". D aar waar die regierol wel consequent wordt ingevuld, zoals in de casus $\mathrm{M}$ argraten, en waar die blijkt samen te vallen met andere positieve factoren (verandermanagement en een gunstige timing), is het verankerings-resultaat ook positief. (Later wordt dit resultaat overigens weer teniet gedaan door de hierboven genoemde regionale belangenstrijd.) Al met al bevestigt het bovenstaande het belang van de opname van de factor regierol van gemeenten in de dimensie lokale context van het WIZ-model.

In hoofdstuk 10 komt de dimensie draagvlak aan bod. H et gaat hier zowel om determinanten (doelstelling, belang, win-win, consensus en sense of urgency) als om uitingsvormen (onderling vertrouwen, tonen van betrokkenheid, adaptatie) van draagvlak. Paragraaf 10.2 biedt een overzicht van de resultaten uit de feitenbeschrijving, paragraaf 10.3 de resultaten uit de enquêtes en 10.4 de resultaten uit interviews. In paragraaf 10.5 volgt de triangulatie van deze drie bronnen. De conclusie hieruit is dat doelstelling en werkwijze van de samenwerking op een ruim maar deels kwetsbaar draagvlak kunnen rekenen. Als zij het belang van de samenwerking afzetten tegen andere prioriteiten blijken portefeuillehouders terughoudender te zijn dan de gemiddelde respondent uit de enquêtes, inclusief ambtenaren en raadsleden. $\mathrm{O} p$ de stelling " $\mathrm{H}$ et is noodzakelijk dat in onze regio het investeringsbedrag van $\mathrm{H}$ artslag Limburg minimaal gehandhaafd blijft" antwoordt tachtig procent van de respondenten in beide jaren het daar 'tamelijk tot geheel eens' mee te zijn. D e financiën, met name de dreigende bezuinigingen, lijken echter een zwaardere druk te leggen op het draagvlak bij de bestuurders. Verder blijkt de win-win-factor, de mate waarin betrokkenen meer voordeel dan nadeel ervaren, in 2003 bij de helft van de respondenten positief uit te vallen; bij gemeenten scoort deze factor wat lager en het aantal negatief gestemden neemt in 2004 toe. In 2004 blijkt de overeenstemming over de regie (factor consensus) afgenomen te zijn; een andere conclusie is dat het urgentiebesef bij portefeuillehouders en GGD -directie tekortschoot (factor sense of urgency).

O nder de noemer uitingsvormen van draagvlak signaleert bijna de helft van de respondenten in 2004 een dalend onderling vertrouwen. D e factor tonen van betrokkenheid betreft gebeurtenissen of uitspraken waarin concrete stappen voor de inzet van mensen en middelen worden genomen. Ten aanzien van deze factor blijkt dat het ontbreken van tonen van betrokkenheid op de noodzakelijke mo- 
menten méér zegt over het feitelijke draagvlak dan de gevonden positieve uitingen van betrokkenheid. C onclusie is dat een gebrek aan urgentiebesef en het ontbreken van het tonen van betrokkenheid, belangrijke signalen zijn voor een dreigend gebrek aan draagvlak. Al met al levert dit een beeld op van een oorspronkelijk ruim maar kwetsbaar draagvlak, twijfels bij bestuurders over de financiële haalbaarheid, uitblijven van de benodigde concrete stappen en een teruglopende overeenstemming over de regie. $\mathrm{D}$ it beeld past bij het uiteindelijk bereikte, relatief magere verankeringsresultaat.

H oofdstuk 11 bevat een presentatie van de conclusies en aanbevelingen. $\mathrm{H}$ et antwoord op de centrale vraagstelling luidt dat verandermanagement vanuit de G GD ondanks het gebrek aan landelijke financiering voor lokale preventieprogramma's een belangrijke bijdrage kan leveren aan bestuurlijke verankering van regionale samenwerking in de publieke gezondheidszorg. D ie bijdrage bestaat enerzijds uit voldoende operationeel verandermanagement, anderzijds uit leiderschap dat in staat is om preventie overeind te houden in de belangenstrijd met andere prioriteiten. $\mathrm{H}$ et vermogen resultaatcijfers te presenteren vormt een belangrijk maar niet doorslaggevend element binnen het operationele verandermanagement. D e mate waarin verandermanagement succesvol kan zijn, is zeker mede afhankelijk van de lokale context, met name van de wijze waarop gemeenten de regierol invullen. Die regierol betreft zowel de bestuurlijke visie, de prioriteitstelling en de toekenning van middelen, als de interne ambtelijke regie. De regierol houdt verder een goede afstemming in van het gemeentelijke besluitvormingsproces met de professionele processen van uitvoering en evaluatieonderzoek. Verankering van bestuurlijke samenwerking is vooral een kwestie van regie nemen, zowel door de gemeente als door de GGD. Voor het vakgebied van de gezondheidsbevordering, dat in een relatief zwakke positie verkeert ten opzichte van andere GGD -taken, betekent dit dat al leen met actieve steun van de GGD directie en onder regie van de gemeente verankering van samenwerking is te realiseren. D eze conclusie betekent voor de praktijk dat het samenspel van de ge meentelijke regierol, leiderschap en operationeel verandermanagement verbeterd zou moeten worden.

In de discussie (paragraaf 11.3) komen vier verbeterpunten aan bod: 1) een betere afstemming van het politieke besluitvormingsproces op het professionele evaluatieproces, met begrip voor langetermijnplanning en de beperkte meetbaarheid van resultaten; 2) vergroting van de betrokkenheid van gemeenten bij innovaties in de publieke gezondheid, zodat zij de uitkomsten van geslaagde experimenten ook daadwerkelijk willen toepassen; 3) om het onderwerp op de politieke agenda te houden dient de GGD coalities te kunnen aangaan met andere partijen om bij de politiek te lobbyen; dit vergt een GGD -bestuur dat los staat van de politiek; 4) aandacht voor de vraag hoe leiderschap en verandermanage- 
ment vanuit de GGD verder ontwikkelt kunnen worden.

Paragraaf 11.4, de beschouwing, gaat in op de sterke en zwakke kanten van de onderzoeks-opzet. Sterke kanten zijn de uitgebreide feitenverzameling en de triangulatie van feiten en meningen. Zwak punt is de mogelijkheid van selectiebias. D eze bias is zo veel mogelijk bestreden door validering van data met direct betrokkenen en externe experts. Belangrijk is verder de validiteit en betrouwbaarheid van de toepassing van het WIZ-model. D e validiteit is tijdens het onderzoek verbeterd door toevoeging van vier factoren (belangenstrijd, leiderschap, urgentiebesef en regierol gemeenten) en de betrouwbaarheid is getest door de labelling van gebeurtenissen en meningen uit te laten voeren door verschillende 'assessors' (beoordelaars) en deze onderling te vergelijken. D e conclusie is dat de gevonden resultaten voldoende valide en betrouwbaar zijn om de hieruit getrokken conclusies en aanbevelingen te rechtvaardigen.

Paragraaf 11.5 biedt een vertaling van de vier punten uit paragraaf 11.3 naar een vijftal aanbevelingen. D e eerste aanbeveling betreft een pleidooi voor gedetailleerde afspraken tussen gemeenten en G GD over continuering op lange termijn van breed opgezette preventieprogramma's, die vastgelegd worden in raadsbesluiten. D e tweede aanbeveling houdt een pleidooi in voor een sterkere betrokkenheid van gemeenten bij de toekenning van innovatie-gelden. Ten derde wordt gepleit voor de afschaffing van de dubbele-pet-constructie voor GGD bestuurders en voor versterking van dit bestuur met vertegenwoordigers uit het veld met voldoende professionele kennis en een onafhankelijke positie ten opzichte van het gemeentelijke bestuur. G esuggereerd wordt om hierbij ook de zich sterk ontwikkelende RO S'en (Regionale 0 ndersteuningsStructuur voor de eerste lijn) te betrekken. D e vierde aanbeveling betreft de ontwikkeling van een landelijk erkende set van 'procesindicatoren voor gezondheidsbevordering'. De laatste aanbeveling, ten slotte, betreft een pleidooi voor nader onderzoek naar de mogelijkheden om de leiderschapsrol vanuit de GGD verder te ontwikkelen en te stimuleren. 


\section{The administrative embedment of}

innovations in public health care; lessons learned from the Hartslag Limburg case. Summary

This thesis deals with the collaboration between organisations that contribute to public health care and with the complex way in which such collaboration on innovative projects can be continued or embedded through administrative decision-making.

Chapter 1 formulates the problems. H ealth as well as public health care are seen as increasingly important. At a local level, municipalities and the M unicipal H ealth Service (GGD) are key players, especially in the area of health promotion. Promoting healthy behaviour requires durable collaboration between these and other prevention partners. This poses a weighty challenge to the parties involved. The $D$ utch situation is characterised by the legal role of municipalities and the function of the GGD as a regional professional organisation at the service of the municipalities. Its professional position makes the GGD the pre-eminent broker for regional and local collaboration. It has limited legal means, however, to take on this role, and the administrative responsibility lies with the municipalities. W ithin this area of tension, knowledge is needed about how the embedment of collaboration works in practice, which factors play a part in it and how those factors can be influenced. There is not much literature about this. In order to generate fresh knowledge, it is important to tap into the experience of exemplary projects. $\mathrm{O}$ ne such project is $\mathrm{H}$ artslag $\mathrm{L}$ imburg (H eartbeat Limburg) from the region of Southern South Limburg (M aastricht and surrounding municipalities). This region was the scene of intensive collaboration from 1998 to 2004 between the GGD , municipalities, family doctors, the University H ospital M aastricht (azM ), the $M$ aastricht U niversity (UM ) and other local partners, with the goal of reducing cardiovascular diseases and ensuring permanent innovation in their collaboration. Among other things, ongoing evaluation studies into implementation processes, effects and cost effectiveness turned this case into an excellent opportunity to study processes at the administrative level. The central question of the study was: "In what way and to what extent can change management from the GGD, within the context of local circumstances and external factors, contribute to the administrative embedment of regional collaboration in public health care?' 
Chapter 2 describes how $\mathrm{H}$ artslag Limburg was set up as a model project from 1994 to 1998. The leading principle at the start of the project was the involvement in health-promoting actions and procedures of both the local population and the care providers and institutions on the scene. This resulted in two subsidiary projects: a municipal or 'community' project, in which the GGD, municipalities, welfare work and local organisations collaborated to promote healthy lifestyles, and a so-called high-risk project which saw collaboration between the GGD , family doctors and the hospital to improve the support of patients at high risk of cardiovascular disease. In the build-up phase, which lasted over three years, contributions from research, practice and policy were welded together piece by piece. We look at the characterising elements of the organisational structure and the factors that have contributed to collaboration or, instead, impeded it. The conclusion is that in this case, collaboration was improved by the involved and stimulating role of a main sponsor, local political commitment, a positive investment climate, a step-by-step approach with partners with a history of cooperation, and social entrepreneurship. Reflection on these factors, coupled with the experiences from the project years, has led to the ambition to make the intended embedment of this collaboration amenable to investigation.

Chapter 3 starts out with a description of the theoretical model. This so-called 'W IZ' model was developed by the U M 's capacity group Beleid, Economie \& O rganisatie van de Zorg (Policy, Economy and O rganisation of Care), and was adapted to the setting of the administrative level of public health care. The model distinguishes between four dimensions or clusters of factors that have influenced the administrative embedment of collaboration. Change management (1) - consisting of vision, social entrepreneurship and strategies for exerting influence, among other elements - should lead to the desired administrative embedment of collaboration, but is influenced by external factors (2), the local context (3) and the extent of support (4). The extent of administrative embedment is determined by looking at four aspects: degree of formalisation, durability, employment of people and means, and range. Following this model, the central question has been split up into sub-questions which address the results per dimension and the relationships between dimensions. An example is the question to what extent the change management actions put into effect are influencing the support base and the administrative embedment. Validation with the help of an expert panel has enriched the model, putting more of an emphasis on the conflict of interest between stakeholders and the municipal directing role as part of the local-context dimension, and the role of leadership as part of change management. We then deal with the research method. This consisted of a so-called 'embedded' single-case study into H artslag Limburg from $\mathrm{O}$ ctober 2002 to $\mathrm{O}$ ctober 2005. $\mathrm{D}$ ata collection took place through a review of the documentation and two data 
collection rounds, held through 2003 and 2004, with written questionnaires and individual interviews with stakeholders. The stakeholders in this study are the public health administrators of the five municipalities in the region of M aastricht, members of the municipal council committees, public health civil servants, direction, staff, middle management and the $\mathrm{H}$ artslag Limburg project leader of the GGD , direction and middle management of regional welfare work, participating family doctors in the region, the direction of the azM , the management of the Cardiology department and the later $\mathrm{C}$ ardiovascular Centre of the azM and the healthcare insurer's contact person. The first step in the analysis was a description of the events in a table, working from the documentation study, in which data was ordered chronologically and following the WIZ model. The factual data analysis was carried out through a so-called time sequence analysis, in which the data from three sources - factual description, questionnaires and interviews - was compared (triangulation).

Chapter 4 offers an overview of the main results of the factual description: the extent of administrative embedment at the time of the initial and final measurements (paragraph 4.2), and a chronological report of the events that took place between the two measurements (paragraph 4.3). The accomplished administrative embedment in 2005 shows an uneven pattern. In the collaboration between the GGD and municipalities, progress has been made in two of four aspects: the degree of formalisation and durability. $\mathrm{H}$ artslag Limburg was converted into two products that have been incorporated into the GGD 's basic package which all municipalities are using. The other two aspects, however, employment of means and scope, show a clear decline in collaboration. A significant reduction of the budget has broken up the collaborative structure where civil servants and local working groups were involved, causing the level of collaboration to decline to about half of its former extent. Remarkably, the adoption of $\mathrm{H}$ artslag Limburg in municipal policy documents has not led to the intended level of administrative embedment. Further, collaboration with family doctors has ended, partly due to a lack of structural funding, while collaboration with the hospital will be sustained at roughly the same level for two and a half years.

The chronological report then offers a preliminary, condensed view of developments from 2002 to 2005 based on the factual description. This shows that most of the events took place on the municipal side of $\mathrm{H}$ artslag L imburg. The remaining analysis, therefore, largely concerns the collaboration between the GGD and the municipalities. The perspective on the collaboration between the GGD, family doctors and the university hospital is dealt with briefly. Chapter 4 ends with a preliminary enumeration of the factors that have influenced the end result where it comes to administrative embedment: nationwide, a cut in municipal funding and locally, a difficult relationship between the GGD and municipalities, financial 
disappointments, the fusion process between the Southern Limburg G GD s and the possible shortcomings of the change management. Later chapters offer an indepth analysis structured along the individual dimensions of the WIZ model.

Chapter 5 offers an analysis of the external factors dimension of the W IZ model. Paragraph 5.2 goes into the influence of nati onal policy, while paragraph 5.3 deals with the attitude of national funding agencies. The conclusion is that the national policy creates new obligations and guidelines for professionals and administrators at the local level without there being clarity about adequate funding. As a result, national organisations (the Association of N etherlands M unicipalities - VN G; GGD N ederland) and the national government are passing responsibility around. W hile this discussion was ongoing, at the start of 2003, the national government went so far as to cut back significantly on municipal funding. Among local government, this development has led to a broadly shared reaction: there is a will to take the Collective Prevention Act and the H ealth M inistry's Prevention Policy D ocument seriously, but a lack of extra funding for health promotion - not to mention additional generic cuts in funding - is seen as preventing the implementation of an innovative approach. A similar development can be seen in the collaboration between the GGD on the one hand and family doctors and the hospital on the other hand: on the national level there is insecurity about funding, and healthcare insurers are saying they no longer dispose of additional means for pre vention. As of early 2003, these external factors have considerably eroded the climate for administrative embedment of the collaboration around $\mathrm{H}$ artslag Limburg.

Chapter 6 analyses the dimension of the local context. Three paragraphs go into the separate factors within this dimension. Paragraph 6.2 shows that there has been 'friction' within the existing collaborative relations between the GGD and municipalities. Paragraph 6.3 describes how three characteristics of management have exerted an impeding influence on the embedment of the community part of $\mathrm{H}$ artslag Limburg (collaboration between municipalities, GGD and welfare work): a lack of financial transparency, different views on the finiteness of projects, and the fusion of the three Southern Limburg GGD s. Paragraph 6.4 points out that the GGD and municipalities are engaged in a conflict of interest on five themes: internal competition around GGD policy priorities, 'investing or economising', 'welfare or health', 'local or regional', and the 'two hats' of the municipal administrator (alderman) who is also a GGD administrator. This conflict of interest, among other things, leads to a lack of investment in innovation. The conflict of interest around these five themes is mostly due to inadequate municipal direction. Looking at these three factors together, we can conclude that the dimension of the local context has not been conducive to the administrative 
embedment of the community part of $\mathrm{H}$ artslag Limburg. The mounting impediments, almost all due to a lack of funds, can be seen both in 2003 and 2004, and have contributed to growing tension. The nature of the local context, along with the characteristics of the external factors as described in chapter 5 , shows that the GGD 's change management has had to operate in an unfavourable climate.

Chapter 7 looks more closely at the definition of the concepts 'municipal direction', 'leadership' and 'change management'. This is needed, since the conclusion in chapter 6 points to flawed direction by municipalities. An analysis of the dimension of change management (from within the GGD) and, within that, the factor of leadership, can only be carried out when it is clear how these two relate to municipal direction. Paragraph 7.2 offers a concise overview of the various theoretical views of the concept of leadership. In paragraph 7.3 this leads to the following general definition of this concept: leadership is a relationship betwen a leader and their followers which both parties can influence and which aims to reach tangible results fitting the shared communal objectives. A lack of leadership is characterised by the avoidance of action and decision-making, denial of responsibility and a failure to use authority.

In paragraph 7.4, this definition is taken as the point of departure for a definition of the concept of municipal di rection as a special form of direction aimed at achieving more unity among stakeholders, their objectives and their actions, with the goal of achieving a certain result. Such direction requires a clear municipal vision, translated as the setting of political-administrative priorities, as well as making decisions about the required and available municipal means to this end. Flawed direction, on the other hand, is characterised by the avoidance of decisionmaking around political-administrative priorities, ignoring the responsibility for determining required means and a failure to use authority. M unicipalities have delegated most of the executive aspects of the directing role to the GGD .

Paragraph 7.5 fine-tunes the concepts of change management and leadership from within the GGD. The essence of the chosen definition of leadership from within the GGD is a focus on the strategic role of the GGD 's director in formulating (executive) goals and the extent to which they use their personal authority to reach those goals. Paragraph 7.6 ends with an adaptation of the W IZ model which sees the addition of the factor of municipal direction to the dimension local context (figure 7.1).

Chapter 8 deals with the change management actions (in brief: actions for change) undertaken from within the GGD. Five factors can be distinguished within this dimension: vision, social entrepreneurship, strategies for exerting influence, network development and leadership. The first four factors are summed up with the term operational change management. The leadership factor specifically relates to the 
director's role as a stakeholder. Paragraph 8.2 offers an overview, taken from the factual description, of the number of actions for change per factor, as a lead-in to paragraph 8.3. This paragraph elaborates on the meaning of this by chronologically describing the foremost actions for change in each year. The paragraph completes the time sequence analysis with triangulation using data from interviews and questionnaires. This triangulation pays specific attention to the extent to which the actions for change have had effect in the areas of support and embedment. Paragraph 8.4 demonstrates that three (sub-)cases within the case of $\mathrm{H}$ artslag Limburg can be compared: the process between the GGD and the municipal ity of $M$ aastricht as an example of failing change management and leadership, and the cases of $M$ argraten and azM as examples of success. An important share of the GGD 's actions for change has had a positive effect on the support for embedment, especially at the start of the embedment process in the first half of 2003. This led to the adoption of $\mathrm{H}$ artslag Limburg in municipal policy documents and in the azM 's policy. M idway through 2003, however, it became clear that the GGD 's actions were insufficient and that support was volatile. The change management, it turned out, had no influence on the economising plans of the municipality of $\mathrm{M}$ aastricht and fell short at times when it would have been necessary to remind municipalities of agreements they had bound themselves to. 0 pportunities for coalition building and exercising leadership were passed up. In spite of the imposed cuts in funding, the director of the GGD accepted the brief from the municipalities to continue $\mathrm{H}$ artslag Limburg. On 15 April 2004, the front page of the daily Volkskrant carried the positive evaluation figures which RIVM (N ational Institute for Public H ealth and the Environment) and the GGD had presented in Rotterdam that morning at the $\mathrm{N}$ ational Public $\mathrm{H}$ ealth Conference. This conspicuous action for change turned out not to be decisive. It did become clear that the approach in $M$ argraten was effective thanks to the combination with a favourable local context (directing role of the public health administrator and timing). There was no such favourable combination in $M$ aastricht, where the results arrived too late to undo the cuts in funding. In its collaboration with the azM , the hospital management had an active directing role and there was additional external funding. The contrast of the (sub-)cases shows that when strong leadership on the part of the GGD is lacking, there is a great risk of poor embedment.

Chapter 9 highlights the municipal directing role in the case. D ata triangulation shows that this role has failed in a number of crucial aspects. The municipal vision, recorded in the policy document on local health care policy, was not reflected in the assignment of priorities; agreements reached before with other stakeholders were not kept; alignment with ongoing research was pledged but not fulfilled; the internal direction was inadequate; and the required budget for both 
welfare work and the GGD was cut. This lack of direction was mainly seen in the dominant municipality of $\mathrm{M}$ aastricht, but the cuts in funding there were eventually felt by the other public health administrators since the other municipalities refused to have a higher pro rata contribution than $M$ aastricht (regional conflict of interest). In interviews, some public health administrators confirmed that municipalities "still need to grow into that directing role". In places where this role was given due weight, as in the case of $M$ argraten, and where it coincided with other positive factors (change management and favourable timing), the embedment result was also positive. (Later, however, this result was undone by the aforementioned conflict of interest.) All in all, the preceding confirms the importance of including the factor of the municipal directing role in the W IZ model's local context dimension.

The dimension support is addressed in chapter 10. This concerns both determinants of support (aim, importance, win-win, consensus and sense of urgency) and expressions of support (mutual trust, showing commitment, adaptation). Paragraph 10.2 offers an overview of the results of the factual description, while paragraphs 10.3 and 10.4 go into the results of the questionnaires and the interviews, respectively. These three sources are triangulated in paragraph 10.5. The conclusion from this is that the aim and method of this collaboration have broad support, even if this support is fragile in places. When weighing the importance of the collaboration against other priorities, public health administrators turn out to be more cautious than the average respondent in the questionnaires, including civil servants and councillors. Eighty percent of respondents in both years indicated they "agreed partly or wholly" with the statement "It is necessary at least to maintain the amount of investment in $\mathrm{H}$ artslag Limburg in our region." Financial factors, especially looming budget cuts, appear to exert a stronger influence on the level of support among administrators. Also, the win-win factor, the extent to which those involved perceive more of an advantage than a disadvantage, was positive among half of all respondents in 2003. Among municipalities the score for this factor was somewhat lower, and the number of negative views rose in 2004. In that year, agreement on who assumes the directing role (the consensus factor) turned out to have decreased. Another conclusion is that the sense of urgency among public health administrators and the GGD direction was lacking. Under the denominator expressions of support, nearly half of all respondents in 2004 report a decrease in mutual trust. The factor showing commitment relates to events or statements with which concrete steps are taken to employ people and means. W ith respect to this factor, a lack of shown commitment at key moments turns out to be a more meaningful predictor of the actual support than the positive expressions of commitment that were recorded. The conclusion from this is that a lack of a sense of urgency and of shown commitment are important signals 
that point to a threatening lack of support. All in all, this paints the picture of originally broad but volatile support, doubts among administrators about the financial feasibility, a failure to undertake the needed concrete steps and declining agreement about who assumes the directing role. This view is confirmed by the actual, fairly disappointing embedment result.

Chapter 11 presents the conclusions and recommendations. The answer to the central question is that change management from within the GGD, in spite of a lack of national funding for local prevention programmes, can make an important contribution to the administrative embedment of regional collaboration in public health care. This contribution exists of sufficient operational change management, as well as leadership which manages to sustain prevention in the face of a showdown with competing priorities. The ability to present conclusions in figures is an important, if not decisive element of operational change management. The extent to which change management can be successful certainly depends in part on the local context, in particular the way in which municipalities develop their directing role. This directing role involves the administrative vision, the setting of priorities and the assignment of means, as well as the coordination of internal administrative processes. Further, the directing role involves gearing the municipal decisionmaking process to the professional processes of program implementation and evaluation research. Embedding managerial collaboration is mostly a question of direction from both the municipality and the GGD. For the professional field of health promotion, which has a relatively weak position compared to other GGD responsibilities, this means that the effective embedment of collaborative public health programmes is only possible with municipal steering and the active support of the GGD direction. In practice, this conclusion means that the dynamic of the municipal directing role, leadership and operational change management should be improved.

The discussion touches on four areas to be improved: 1) better alignment of the political decision-making process with the professional evaluation process, with stakeholders accepting that long-term planning may be needed and that results are measurable to a limited degree only; 2 ) increasing the involvement of municipalities with innovations in public health care, so that they have a real desire for implementing the results of succesfful experiments; 3 ) in order to keep the issue on the political agenda, the GGD should be able to build coalitions with other parties in order to carry out a political lobby - this requires a politically independent GGD management; 4) attention for the question of how leadership and change management can be further developed from within the GGD .

Paragraph 11.4, the discussion, looks at the strong and weak points of the study's approach. Strong points are the extensive data collection and the triangulation of facts and opinions. A weak point is the possibility for selection bias. This bias has 
been countered as much as possible by way of data validation with direct stakeholders as well as external experts. The validity and reliability in the application of the W IZ model is al so important. The validity was improved during the study by including four factors (conflict of interest, leadership, sense of urgency and municipal direction), while the reliability was tested by letting different assessors carry out the labelling of events and opinions and comparing their work. The conclusion is that the results thus encountered are sufficiently valid and reliable to justify the conclusions and recommendations derived from them.

Paragraph 11.5 translates the four points from paragraph 11.3 into five recommendations. The first recommendation is a plea for detailed agreements between municipalities and the GGD about the long-term continuation of broadly based prevention programmes that are recorded in council decrees. The second recommendation is a plea for closer involvement of municipalities in assigning funds for innovation. Thirdly, the argument is made for abolishing the double role of municipal administrators who are also GGD administrators. The GGD management should be strengthened with representatives from the field who have sufficient professional knowledge and are independent from the municipal government. The suggestion is made to involve the fast-developing ROS (Regional Support Structures for primary health care) in this. The fourth recommendation concerns the development of a nationally recognised set of 'process indicators for health promotion'. The final recommendation is a plea for further research into the possibilities for continued development and stimulation of the leadership role from within the GGD 


\section{Gehanteerde begrippen en afkortingen}

\section{Begrippen}

- Bestuurlijke verankering explici ete afspraken die op het niveau van het bestuur van een organisatie worden vastgel egd op vier aspecten, te weten: formalisati egraad, duurzaamheid, inzet van middelen en reikwijdte.

- Duale stelsel in de gemeenteraad Een striktere scheiding van taken tussen college van $B \& W$ als uitvoerende macht en gemeenteraad als controlerende macht.

- GSB-impulsbeleid

Grote Stedenbeleid: landelijk beleidskader gericht op de problematiek van de \pm dertig grootste steden (minimaal 100.00 inwoners), met financiering en uitgebreide regelgeving vanuit $D$ en $\mathrm{H}$ aag.

- Integrale benadering, integraal beleid

Werkwijze in de gezondheidsbevordering waarbij getracht wordt om synergie te creerren door preventieve interventies of maatregelen vanuit verschillende sectoren binnen en buiten de zorg te bundelen.

- Publieke Gezondheid

D e Publieke Gezondheid ( $N$ ederlands alternati ef voor het in de rest van de wereld gangbare 'public health') is het onderdeel van de totale sector Volksgezondheid dat zich toespitst op de activiteiten vanuit de collectiviteit c.q. de overheid, gericht op de gezondheid van groepen.

- Sociaal-Economische Status

Positie die iemand inneemt in de sociale hiërarchie, gemeten aan de hand van opleiding, inkomen of beroepsstatus.

- Volksgezondheid Toekomst Verkenning

Vierjaarlijkse rapportage van het RIV M over de staat van de N ederlandse volksge zondheid.

\section{Afkortingen}

$A B$

azM

$\mathrm{BEOZ}$
Algemeen Bestuur van de GGD Zuidelijk Zuid Limburg; het AB bestaat uit drie leden van de raad van elke deelnemende gemeente, waarbij geldt dat minstens één van die drie afkomstig is uit het college van $B \& W$.

Academisch ziekenhuis $M$ aastricht

Beleid, Economie \& O rganisatie van de Zorg, een capaciteitsgroep van de U M 
BZC Behandel zorg centrum van het azM, eenheid waarin verschillende specialismen worden geclusterd rond een bepaal de categorie patiënten

BZE Behandel zorg eenheid: naam voor de managament-eenheden onder de raad van bestuur van het azM

Capgroep Capaciteitsgroep, een onderzoekseenheid binnen een faculteit van de UM

D B Dagelijks Bestuur van de GGD Zuidelijk Zuid-Limburg; het D B bestaat uit de voorzitter en plaatsvervangend voorzitter van het $A B$, plus drie leden uit het $A B$, met dien verstande dat daarin elk van de vijf gemeenten is vertegenwoordigd met één lid uit het college van $B \& W$.

Fonds O GZ Fonds O penbare G ezondheidszorg, tijdelijk stimuleringsfonds, opgericht door VWS

GGD Gemeenschappelijke G ezondheidsdienst

GGD -zzl GGD Zuidelijk Zuid-Limburg (te M aastricht)

GSB Grote Steden Beleid

GVO Gezondheidsvoorlichting en - opvoeding

H AG Afkorting van de capgroep huisartsgeneeskunde van de U M

NHG N N ederlands H uisartsen Genootschap

N H S N Nederlandse $\mathrm{H}$ artstichting

NIGZ N ationaal Instituut voor Gezondheidsbevordering en

Ziektepreventie

O GZ O penbare Gezondheidszorg

$\mathrm{PH}$

RIVM Rijks Instituut voor Volksgezondheid en Milieu

SWEH Stichting Welzijnswerk en Educatie H euvelland, vanaf 2001 opgegaan in Trajekt

Trajekt Organisatie voor welzijnswerk in M aastricht e.o.

UM Universiteit M aastricht

VGZ Zorgverzekeraar VGZ

VNG Vereniging van N ederlandse G emeenten

VTV Volksgezondheid Toekomst Verkenning (rapport RIV M )

VW S M inisterie van Volksgezondheid, Welzijn \& Sport

WCPV Wet Collectieve Preventie Volksgezondheid

W IZ-model Theoretisch model van de Werkgroep Integrale Zorg van de capgroep BEO Z van de UM, dat een ordeningskader biedt voor factoren die van invloed zijn op inter-organisationele samenwerking 


\section{Literatuur}

- Assema, P. van (1993). The development, implementation and evaluation of a community health project. Proefschrift, Universiteit $M$ aastricht.

- Assema, P. van, Steenbakkers, M ., Bastiaens, C., Ronda, G. (2006). H artslag Limburg: integrale gezondheidsbevordering in buurten, gemeenten, bij huisartsen en in het ziekenhuis; D eel 2. H et interventieproces van het Communityproject binnen $\mathrm{H}$ artslag Limburg. TSG Tijdschrift voor Gezondheidswetenschappen 84 (4), pp.231-237.

- Bass, B.M ., Stogdill, R.M . (1990). H andbook of Leadership. Free Press, N ew York.

- Boelen, C. (2000a). Towards U nity for H ealth: Challenges and O pportunities for Partnership in $\mathrm{H}$ ealth Development. G eneva: World $\mathrm{H}$ ealth O rganization.

- Boelen, C. (2000b). Towards U nity for H ealth: C ollaboration wanted. WH $O$ Newsetter Towards U nity for $\mathrm{H}$ ealth,1:1,14-5.

- Boonstra, J.J., Steensma, H .O ., D emenint, M .I. (1998). O ntwerpen en ontwikkelen van organisaties, theorie en praktijk van complexe veranderingsprocessen. U trecht: DeTijdstroom.

- Bracht, N ., K ingbury, L. (1990). Community organization principles in health promotion: A five-stage model. In N. Bracht, (ed), H ealth promotion at the community level (pp. 66-88). N ewbury Park: SAGE Publications.

- Burns, J.M . (1978). Leadership. H arper Row, N ew York.

- Conger, J.A., K anungo, R.N . (1987). Toward a Behavioral Theory of Charismatic Leadership in O rganizational Settings, Academy of $M$ anagement Review, Vol. 12, N 0. 4, pp. 637-647

- Cummings, T.G., Worley, C.G.(1997). Organization D evelopment and Change. Chapter 10, M anaging change. Cincinnati, 0 hio: South Western College Publishing, 153-170.

- Diamond, J. (2006). Zwaarden, paarden \& ziektekiemen; de ongelijkheid in de wereld verklaard. Utrecht, Spectrum, p.155.

- D uncan, W.J., G inter, P.M . \& Swayne, L.E.(1998). Handbook of H ealth Care $M$ anagement. O xford: Blackwell Publishers Ltd.

- Fiedler, F.E. (1964). "A contingency model of leadership effectiveness", in Advances in Experimental Social Psychology, Vol 1, L. Berkowitz, ed., Academic Press, N ew York. 
- GGD Zuidelijk Zuid-Limburg (1989). Uit Voorzorg; Ontwerp-beleidsplan voor de jaren negentig. Districtsgezondheidsdienst Zuidelijk Zuid-Limburg, M aastricht.

- Gini, A. (1995). "Too much to say about something": a review article on J.C. Rost's 'Leadership for the Twenty-first C entury'. Business Ethics Q uarterly, Volume 5, Issue 1, pp.143-155.

- H aes, W. de, Voorham, A., M ackenbach, J. (2002). Wijkgericht werken aan gezondheidsbevordering in vier achterstandswijken in Rotterdam; opzet, uitgangspunten en beschrijving van het proces. TSG Tijdschrift voor Gezondheids wetenschappen 425-430.

- H arting, J. (2005a). Individual lifectyle advice development, implementation, and evaluation within the $\mathrm{H}$ artsag Limburg cardiovascular prevention project. Proefschrift Universiteit M aastricht.

- H arting, J., A ssema, P. van, Ruland, E., Limpt, P. van, Gorgels, T., Re, J. van, Vermeer, F., Vries, N.K. de (2005b). Implementation of an innovative health service: a "real world" diffusion study. American Journal of Preventive M edicine, 29:113-119.

- H arting, J., Assema, P. van, Vries, N .K. de (2006a). Proces-en effectevaluatie van het hoogrisicoproject binnen $\mathrm{H}$ artslag Limburg. TSG Tijdschrift voor Gezondheidswetenschappen 84:343-353.

- H arting, J., Assema, P. van, Vries, N.K. de (2006b). Patients' opinions on health counseling in the $\mathrm{H}$ artslag Limburg cardiovascular prevention project: perceived quality, satisfaction, and normative concerns. Patient Education and Counseling, 61:142-151.

- H arting, J., Assema, P. van, Limpt, P. van, Gorgels, T., Ree, J. van, Ruland, E., Vermeer, F., Vries, N.K. de (2006c). Effects of health counseling on behavioral risk factors in a high-risk cardiology outpatient population: a randomized clinical trial. European Journal of Cardiovascular Prevention and Rehabilitation, 13:214-221.

- H arting, J., Assema, P. van, Limpt, P. van, Gorgels, T., Ree, J. van, Ruland, E., et al. (2006d). Cardiovascular prevention in the $\mathrm{H}$ artslag Limburg project:

Effects of a high-risk approach on behavioral risk factors in a general practice population. Preventive M edicine, 43:372-378.

- H ogan, R.C.G.J. \& H .J. (1994). "W hat we know about leadership: Effectiveness and personality", American Psychologist, vol 49, pp. 493-504.

- Hollander, A.E.M . de, et al (red). (2006). Zorg voor de gezondheid; Volksge zondheid Toekomst Verkenning 2006. RIVM Centrum voor Volksgezondheid Toekomst Verkenningen. H outen, Bohn Stafleu Van Loghum.

- Horstman, K, H outepen, R. (2005). Worstelen met gezond leven. Ethiek in de preventie van hart- en vaatziekten. Amsterdam, $H$ et Spinhuis. 
- Hosking, D.M , M orley, I.E. (1991). A social psychology of organizing: People, processes and contexts. London: $\mathrm{H}$ arvester Wheatsheaf.

- Jansen, M ., Dirx, K., Ruland, E, M unter, H . de. (1992). Een uitwerking van gezonde stad. Regionaal preventieplan hart- en vaatziekten Zuid-Limburg. Nieuwsorief N etwerk Gezonde Steden nr. 4, mei.

- Jansen, J., Schuit, A.J., Lucht, F. van der (2002). Tijd voor gezond gedrag; Bevordering van gezond gedrag bij specifieke groepen. RIVM Centrum voor Volksgezondheid Toekomst Verkenningen. H outen, Bohn Stafleu Van Loghum.

- Kingdon, J.W. (1995). Agendas, Alternatives and Public Policies N ew York: $\mathrm{H}$ arper Collins College Publishers.

- Kooiker, S., Velden, J. van der (2007). Een nuchtere kijk op gezond gedrag. D en $\mathrm{H}$ aag, SCP.

- Leurs, M ., Jansen, M ., Ruiter, M . (2002) Coordinated School H ealth Program: het 'Gezonde School M odel' van de Toekomst? TSG Tijdschrift voor Gezondheidswetenschappen 80: 471-2.

- Leurs, M ., M ur-Veenman, I., Schaalma, H ., Vries, N . de. (2003). Integrale samenwerking gaat verder dan de samenwerking tussen professionals: introductie van het DISC-mode. TSG Tijdschrift voor Gezondheidswetenschappen 2003;81: 369-73.

- Likert, R. (1961). N ew Patterns in M anagement. M cG raw-H ill, N ew York.

- Likert, R. (1967). The H uman O rganization: Its M anagement and Value. M cGraw-H ill, N ew York.

- Lippeveld, T., G lasser, J. (2003). M easuring Progress Towards U nity for H ealth: Lessons Learned from Twelve Field Projects. Paper presented at the $\mathrm{N}$ etwork TUFH Conference 'Towards Equity in Education, Service and $\mathrm{H}$ ealth $\mathrm{C}$ are D elivery', N ewcastle, Australia, 0 ctober 11-15.

- M cKee, M ., Zwi, A., Koupilova, I., Sethi, D ., Leon, D. (2000). H ealth policymaking in central and eastern Europe: lessons from the inaction on injuries? $H$ ealth Policy and Planning 15(3): 263-269.

- M iles, M., Huberman, A. (1994). Q ualitative data analysis. An Expanded Sourcebook. Thousand O aks, CA: Sage.

- M inister de Geus, minister voor Volksgezondheid (2002). Reactie op het samenvattend rapportVolksgezondheid Tokkomst Verkenning 2002. Brief aan de voorzitter van de Tweede Kamer. D en H aag, M inisterie van VW S, 21.11.2002. 
- M inisterie van Binnenlandse Zaken (2006). D e gemeente als regi sseur; lokale daadkracht mobiliseren. D en $\mathrm{H}$ aag, M inisterie van Binnenlandse Zaken. http://www.minbzk.nl/onderwerpen/openbaar-bestuur/interbestuurlijke/regierol-gemeenten?Actltmldt=103909

- M inisterie van VW S (2003). Langer Gezond leven; ook een kwestie van gezond gedrag. D en $\mathrm{H}$ aag, ministerie van VW S.

http://www.minvws.nl/kamerstukken/zzoude_directies/pog/kabinetsnota_langer_gezond_leven_ook_een_kwestie_van_gezond_gedrag.asp

- M inisterie van VW'S (2007). Gezond zijn, gezond blijven. Een visie op gezondheid en preventie. D en H aag, ministerie van VW S. http://www.minvws.nl/images/pg2798399b_tcm19-152845.pdf

- M organ, G.(1986). Images of O rganization. Beverly Hills, Calif.: Sage Publications, 77-109.

- M organ, G . (1993). Imaginization. N ew M indsets for Seeing, O rganizing, and $M$ anaging. Beverly H ills, Calif.: Sage Publications, 327.

- M ur-Veeman, I., Raak, A. van, and M aarse, H . (1994). D utch home care: towards a new organization? H ealth Policy, 27, 141-56.

- O ers, J.A.M . van (red). (2002). G ezondheid op koers? Volksgezondheid Toekomst Verkenning 2002. RIVM Centrum voor Volksgezondheid Toekomst Verkenningen. H outen, Bohn Stafleu Van Loghum.

- Pyorala, K., D ebacker, G ., Graham, I., Poole-W ilson, P., Wood, D. (1994). Prevention of coronary heart disease in clinical practice. Recommandations of the task force of the European Society of Cardiology, European atherosclerosis Society and European Society of hypertension. European H eart Journal; 15:1300-31.

- Plsek, P.E., G reenhalgh, T. (2001). Complexity science; the challenge of complexity in health care. British M edical Journal 323:625-8.

- Plsek, P.E., W ilson, T. (2001). Complexity Science; complexity, leadership, and management in health care organisations. B ritish M edical Journal 323:746-9.

- Raad voor het O penbaar Bestuur. (1999) 'O p het toned en achter de coulissen; de regiefunctie van gemeenten'. D en $\mathrm{H}$ aag, Raad voor het O penbaar Bestuur. http:// www.rob-rfv.nl/default.aspx?skin $=$ Rob \& inc=detail $\&$ id $=156 \&$ type=publicatie

- Raad voor de Volksgezondheid \& Zorg. (2006). Publieke Gezondheid. D en H aag, RVZ.

- Raak, A. van, M ur-Veeman, I. and Paulus, A. (1999). U nderstanding the feasibility of integrated care: a rival viewpoint on the influence of actions and the institutional context. Int J H ealth Planning M anagement, 14, 235-48. 
- Ronckers, E.T., G root, W., Steenbakkers, M ., Ruland, E., Ament, A. (2006a). Costs of the ' $\mathrm{H}$ artslag Limburg' community heart health intervention. BioM ed Central Public Health, 6:51.

- Ronckers, S. (2006b). Economic evaluation of prevention programs for cardiovas cular diseases Proefschrift Universiteit M aastricht. Enschede, PrintPartners Ipskamp, pp. 143-160.

- Ronda, G.M . (2003). The D utch heart health community intervention 'H artsag Limburg; an evaluation. Proefschrift U niversiteit van M aastricht.

- Ronda, G., Assema, P. van, Candel, M., Ruland, E., Steenbakkers, M., Ree, J. van, Brug, J. (2004). The D utch heart health community intervention 'H artslag Limburg': results of an effect study at individual level. Health Promotion International 19(1):21-31.

- Rost, J.C. (1993). Leadership for theTwenty-first Century. Westport, CT: Praeger Press.

- Ruland, E., Dirx, K., Jansen, M ., M unter, H. de. (1994). Regionaal Preventie plan $\mathrm{H}$ art- en vaatziekten; incidentie en preventie van hart- en vaatzi kkten in de regio Zuidelijk Zuid-Limburg. M aastricht, D istrictsgezondheidsdienst Zuidelijk Zuid-Limburg.

- Ruland, E. (eindredactie) (1999a). Hartslag Limburg O perationeel Scenario, U pdate 1999. M aastricht, GGD Zuidelijk Zuid-Limburg.

- Ruland, E., H arting, J., Limpt, P. van, Ronda, G., Assema, P. van, Ree, J. van. (1999b), et al. 'H artslag Limburg': a united approach in preventive care; community-based prevention integrated with a high risk group approach in general practices and in the hospital. A case study summary in the framework of WH O's 'Towards unity for health' project. M aastricht, GGD Zuidelijk Zuid-Limburg.

- Ruland, E., Raak, A. van, Spreeuwenberg, C., Ree, J. van (2003). M anaging $\mathrm{N}$ ew Public $\mathrm{H}$ ealth: hoe zijn blijvende preventieve samenwerkingsverbanden te realiseren? Een agenda voor actie en onderzoek. TSG Tijdschrift voor Gezondheids wetenschappen 52-55.

- Ruland, E., Assema, P. van, Ree, J. van, et al. (2006a). H artslag Limburg: integrale gezondheidsbevordering in buurten, gemeenten, bij huisartsen en in het ziekenhuis; D el 1. D e opbouw: bundeling van praktijk, onderzoek en beleid. TSG Tijdschrift voor Gezondheidswetenschappen 84 (2), pp. 83-89.

- Ruland, E. (2007). H artslag Limburg: lessen uit de praktijk. In H . D agevos \& G. M unnichs (red.), D e obesogene samenleving. M aatschappelijke perspectieven op overgewicht (pp. 144-152). Amsterdam: U niversity Press.

- Saan, H ., H aes, W. de (2005). Gezond effect bevorderen. H et organiseren van effectieve gezondheidsbevordering. Woerden, N IGZ. 
- Schuit, J. et al. (2006). Effect of 5-year community intervention H artslag Limburg on cardiovascular riskfactors. American Journal of Preventive M edicine M ar;30(3):237-42.

- Scott, W.R. (1992). Organizations Rational, natural, and open systems. Engelwood Cliffs, N J: Prentice-H all International Editions.

- Shamir, B., H ouse, R.J., Arthur, B.M . (1993). The M otivational Effects of Charismatic Leadership: A Self-C oncept Based Theory. O rganization Science, Vol. 4, N o. 4 (Nov., 1993) , pp. 577-594.

- Staatsblad 2002a, 468. Wet van 13 juli 2002 tot wijziging van deWet collectieve preventie volksgezondheid; paragraaf 2, resp. artikel 2.1, 2.2.c en 5.1.

http://www.st-ab.nl/wetten/0446_Wet_collectieve_preventie_volksgezondhedd_W cpv. htm

- Staatstoezicht op de volksgezondheid, Inspectie voor de gezondheidszorg. (2005). Staat van de gezondheidszorg 2005; O penbare gezondheidszorg: hoe houden we het volk gezond? D en H aag, IGZ, p.16.

- Tannebaum, R.W.S. (1958). H ow to choose a leadership pattern. H arvard Business Review, vol. 36, no 2, pp. 95-101.

- Tichy, N .M ., D evanna, M .A. (1986). TheTransformational Leader, Wiley, Chichester.

- VN G, (2002). Reactie van VN G op onderzoek naar regierol van gemeenten bij stedelijke vernieuwing, brief aan minister Remkes van VRO M , 07.06.2002. www.vng.nl

- VN G \& GGD N ederland (2004). Visie op schaal. Advies over de schaal grootte van GGD'en. Versie 3.0. Woerden, Utrecht, Den H aag, VNG \& GGD N ederland, pp. 9 en 21. www.vogz.nl/docs/vngenggdvisieschaal grootte.doc

- VN G, (2006a). VN G-visienota over de rol van de gemeenten in de openbare gezondheidzzorg; Elf uitgangspunten voor beleid. D en H aag, V N G, februari 2006 http://www.vng.nl/D ocumenten/Extranet/Sez/ZW S/Visienota_rol_gemeenten_ogz_februari_2006.doc

- VNG (2006b). Brief aan de Vaste commissie voor Volksgezondheid, Welzijn en Sport uit de Tweede K amer der Staten-G eneraal. D en $\mathrm{H}$ aag, U trecht, Woerden, VN G, GGD N ederland \& N IGZ, 28 maart 2006.

- VN G, (2006c). Werken aan gezondhed; een introductie op gemeentelijk gezondheidsbeleid. D en H aag, VN G, 21.04.2006, p.10. http://www.vng.nl/D ocumenten/Extranet/Sez/ZW S/Werken_aan_gezondheid_Een_introductie_op_gementelijk_gezondheidsbeleid.pdf

- Voorham, A., H aes, W. de, M ackenbach, J. (2002). W ijkgericht werken aan gezondheidsbevordering in vier achterstandswijken in Rotterdam; leerpunten uit de praktijk. TSG Tijdschrift voor Gezondheidswetenschappen 431-435. 
- Vries, M. de (2003). Problemen op de agenda. In A. H oogerwerf en M. Herwijer (red.) Overheidsodeid (pp. 67-87). Alphen aan den Rijn.

- World H ealth O rganisation. (1986). O ttawa charter for health promotion. Journal H ealth Promotion 1:1-14

- Yin, R.K. (1994). Case sudy research: design and methods. Thousand 0 aks, California: Sage,p. 38-44.

- Yukl, G. (1998). Leadership in organizations Englewood Cliffs, N J: Prentice$\mathrm{H}$ all. 


\section{Overzicht databronnen}

\begin{tabular}{|c|c|c|}
\hline $\mathrm{nr}$ & Datum & Titel/Inhoudsaanduiding \\
\hline D1 & Nov. 2001 & $\begin{array}{l}\text { Concept Impulsnota Lokaal Gezondheidsbeleid; Regio Maastricht en } \\
\text { Mergelland. Maastricht, GGD Zuidelijk Zuid-Limburg }\end{array}$ \\
\hline D2 & 31.02.2002 & Notulen Algemeen Bestuur, GGD Zuidelijk Zuid-Limburg \\
\hline D3 & 16.05.2002 & Notulen Dagelijks Bestuur, GGD Zuidelijk Zuid-Limburg \\
\hline D4 & 25.06 .2002 & Notulen Dagelijks Bestuur, GGD Zuidelijk Zuid-Limburg \\
\hline D5 & 25.06.2002 & Notulen Algemeen Bestuur, GGD Zuidelijk Zuid-Limburg \\
\hline D6 & Okt. 2002 & $\begin{array}{l}\text { SGBO, (2002). Monitor lokaal gezondheidsbeleid; resultaten nulmeting. } \\
\text { Den Haag, SGBO }\end{array}$ \\
\hline D7 & 10.10.2002 & Notulen halfjaarlijks overleg van GGD-Hartslagteam met ambtenaren. \\
\hline D8 & 15.10 .2002 & $\begin{array}{l}\text { Dagboeknotitie. Inhoud: verslag overleg projectleider, medewerkers } \\
\text { Hartslag Limburg, staflid en afdelingshoofd AGZ van de GGD }\end{array}$ \\
\hline D9 & 16.10.2002 & $\begin{array}{l}\text { Emailwisseling tussen GGD-medewerkers over spanningsveld gemeente- } \\
\text { GGD en contacten met raadsleden }\end{array}$ \\
\hline D10 & 17.10.2002 & Notulen Dagelijks Bestuur, GGD Zuidelijk Zuid-Limburg \\
\hline D11 & 17.10.2002 & Notulen Algemeen Bestuur, GGD Zuidelijk Zuid-Limburg \\
\hline D12 & 18.10 .2002 & $\begin{array}{l}\text { Dagboekaantekeningen. Emailcontacten tussen staf van GGD-zzl en } \\
\text { medewerkers VWS. Mondelinge mededelingen door staflid. }\end{array}$ \\
\hline D13 & 23.10.2002 & $\begin{array}{l}\text { Verslag bijeenkomst op ministerie van Binnenlandse Zaken in aanwezig- } \\
\text { heid van ambtenaar Maastricht, staflid GGD-zzl en senior beleidsmede- } \\
\text { werker directie OGZ van ministerie van VWS }\end{array}$ \\
\hline D14 & 31.10 .2002 & $\begin{array}{l}\text { Artikel in Dagblad De Limburger: harde kritiek op Maastrichtse wethou- } \\
\text { der welzijn en volksgezondheid }\end{array}$ \\
\hline D15 & 14.11.2002 & Notulen overleg GGD-Hartslagteam met gemeente Maastricht en Trajekt \\
\hline D16 & 15.11.2002 & $\begin{array}{l}\text { Diverse krantenartikelen n.a.v. de presentatie van de VTV } 2002 \text { 'Gezond- } \\
\text { heid op koers?' (o.a. Dagblad De Limburger, Limburgs Dagblad, Volkskrant) }\end{array}$ \\
\hline D17 & 21.11.2002 & $\begin{array}{l}\text { Minister de Geus, minister voor Volksgezondheid. Reactie van de minister } \\
\text { op het samenvattend rapport Volksgezondheid Toekomst Verkenning } \\
\text { 2002. Brief aan de voorzitter van de Tweede Kamer. Den Haag, Ministerie } \\
\text { van VWS. }\end{array}$ \\
\hline D18 & 21.11 .2002 & $\begin{array}{l}\text { Emailbericht van projectleider Hartslag aan gemeente ambtenaren. } \\
\text { Inhoud: tekst van artikelen die volgende dag in de Volkskrant zullen ver- } \\
\text { schijnen over de VTV } 2002 \text { en Hartslag Limburg }\end{array}$ \\
\hline D19 & 22.11 .2002 & $\begin{array}{l}\text { Invitational conference voor professionals (Utrecht) ter gelegenheid van } \\
\text { de presentatie van de VTV 2002. email met persoonlijk verslag door prof } \\
\text { J. van Ree. }\end{array}$ \\
\hline D20 & 22.11 .2002 & Artikelen in de Volkskrant over VTV 2002 en Hartslag Limburg \\
\hline D21 & 25.11 .2002 & $\begin{array}{l}\text { Emailbericht: Spoedactie van GGD Nederland richting Tweede Kamer, } \\
\text { getiteld: "Begroting VWS 2003: waar blijft de preventie?" }\end{array}$ \\
\hline D22 & 25.11 .2002 & $\begin{array}{l}\text { Programma Bijeenkomst “Lokaal Gezondheidsbeleid: kansen en uitdagin- } \\
\text { gen" voor colleges B\&W en raadsleden van de regio Zuidelijk Zuid- } \\
\text { Limburg. (powerpoinpresentaties) }\end{array}$ \\
\hline D23 & 26.11.2002 & $\begin{array}{l}\text { Artikel in Dagblad De Limburger met de kop: "GGD: gemeenten moeten } \\
\text { investeren in ziektepreventie" }\end{array}$ \\
\hline D24 & 27.11.2002 & Begrotingsbehandeling VWS; 2 moties, Kamerstuk 2002-2003, 28600 XVI, \\
\hline
\end{tabular}


nr. 57 en 72. Motie van Buijs en motie Kant.

28.11.2002 Email van projectleider Hartslag aan gemeente ambtenaren. Inhoud:

Spoedactie van GGD Nederland richting Tweede Kamer, getiteld:

"Begroting VWS 2003: waar blijft de preventie?"

D26 29.11.2002 Email van projectleider Hartslag aan gemeente ambtenaren. Inhoud: Voorstel "Wat betekent Hartslag voor de gemeente?", bespreken van mogelijkheden voor continuering.

D27 Dec 2002 Gezonde Gemeente, 6e jaargang, nr. 4. Den Haag, VNG

D28 02.12.2002 Dagboeknotities en notulen werkoverleg GGD Hartslagmedewerkers en ambtenaren gemeente Eijsden

D29 12.12.2002 Notulen Dagelijks Bestuur, GGD Zuidelijk Zuid-Limburg

D30 20.01.2003 Notulen werkoverleg GGD Hartslagmedewerkers en ambtenaren gemeente Eijsden

D31 22.01.2003 Artikel in Volkskrant over Hartslag Limburg: "Doe eens doperwten in plaats van friet".

D32 29.01.2003 Artikel in Het Limburgs Dagblad met als titel: 'Ook voor weinig geld kun je goed eten', verslag van bezoek landelijke jury aan voedingsproject dat gemeente Maastricht samen met de GGD uitvoert.

D33 29.01.2003 Notulen overleg tussen GGD (staflid, projectleider Hartslag), zorgverzekeraar VGZ en huisartsen

D34 30.01.2003 Brief van VNG aan colleges B\&W van alle gemeenten over Stand van zaken openbare gezondheidszorg (kenmerk SEZ/2002004636 Lbr. 02/172)

D35 30.01.2003 Danen S., Manshanden J. Rapport 'Evaluatie Nationaal Contract Openbare Gezondheidszorg (2001-2003)', Utrecht

D36 31.01.2003 Binnenlands Bestuur: "Kamerleden: 'verdubbel budget ziektepreventie'”

D37 04.02.2003 Dagboeknotities Ambtelijk overleg GGD - Heuvellandgemeenten

D38 7 tot Emailcontacten tussen projectleider van de GGD-zzl met directeur GGD

10.02.2003 en verschillende academische experts. Verwacht wordt dat de eerste effectresultaten nog te mager zullen zijn om gemeenten te overtuigen. Verschillende oplossingsstrategieën worden onderzocht.

D39 $\quad 17.02 .2003$ Notulen overleg Hartslag medewerkers GGD met ambtenaar Maastricht

D40 20.02.2003 Artikelen in Dagblad De Limburger n.a.v. landelijke Stimuleringsprijs 21.02.2003 Openbare Gezondheidszorg

D41 24.02.2003 Notulen overleg GGD-medewerkers en portefeuillehouder en ambtenaren gemeente Meerssen

D42 26.02.2003 Emailbericht. Inhoud: verzoek van projectleider Hartslag aan ambtenaar Maastricht om Hartslag te presenteren in raadscommissie

D43 27.02.2003 Notulen intern overleg GGD. Inhoud: afstemming van producten gezondheidsbevordering tussen afdelingen AGZ en JGZ. Geconcludeerd wordt dat Hartslag Limburg, Schoolslaf en de Gezondheidswijzer tot de kernactiviteiten van de GGD behoren.

D44 27.02.2003 Presentatie van Hartslag Limburg op discussiebijeenkomst van de huisartsenopleiding van de UM.

D45 27.02.2003 Dagboeknotities. Inhoud: verslag overleg GGD-medewerkers en ambtenaren gemeente Valkenburg

D46 01.03.2003 Concept voorjaarsnota van de gemeente Maastricht Artikel in Dagblad De Limburger

D47 07.03.2003 Persbericht GGD Nederland: "2\% extra voor preventie, geen luxe maar noodzaak". Utrecht, GGD Nederland 


\section{D48}

D49 20.03.2003

D50 21.03 .2003

D51 25.03.2003

D52 28.03.2003

28.03.2003 -

03.4 .2003

D54

April 2003

D55

D56 09.04.2003

D57 10.04.2003

D58

11.04.2003

D59

14.04 .2003

D60 16.04.2003

D61 17.04.2003

D62

17.04 .2003

D63 17.04.2003

D64 29.04.2003

D65 29.04.2003

D66 22.05.2003

D67 04.06.2003

Notulen Algemeen Bestuur, GGD Zuidelijk Zuid-Limburg

Presentatie van samenwerkingsplannen tussen azM, GGD en UM door dhr. Carpay, bestuursvoorzitter azM voor het DB van de GGD

concept Nota Lokaal Gezondheidsbeleid 2003 - 2006. Gemeente Maastricht, pp 13-14.

Notulen managementteam GGD-zzl. Bespreking van de visie i.h.k.v. profiel nieuwe directeur. Nadruk wordt gelegd op behouden en structureren van het bereikte en daarvoor draagvlak verwerven bij de gemeenten.

Emailbericht van projectleider Hartslag aan gemeente ambtenaren. Inhoud: verzoek om commentaar op concept van rapport “Hartslag Limburg Voortgangsrapportage 1998-2002”. Maastricht, GGD-zzl, maart 2003.

Emails met reacties van ambtenaren op conceptrapport "Hartslag Limburg Voortgangsrapportage 1998-2002". Inhoud: gemeente willen informatie gemeente-specifiek en meer info over kosteneffectiviteit. Uitgave van rapport “Hartslag Limburg Voortgangsrapportage 19982002”. Maastricht, GGD-zzl. Rapportage t.b.v. gemeenten, raadsleden en andere betrokkenen.

Notulen overleg Managementteam GGD-zzl

Notulen Overleg Ambtenaren Volksgezondheid. Betreft regulier overleg tussen GGD en gemeente ambtenaren. Agendapunt: strategie voor de continuering van Hartslag Limburg.

Mini-conferentie voortgang Hartslag Limburg. Programma voor alle bestuurlijk en uitvoerend betrokkenen. Gastspreker: Hans van Oers, eindredacteur VTV-2002

Emailbericht van projectleider GGD aan betrokken wetenschappers. Planning van speciale bijeenkomsten met onderzoekers en externe experts $(29.09 .03,24.11 .03)$ om onderzoeksresultaten te bespreken en vervolgstrategie te bepalen.

Dagprogramma Bezoek Raadsledencommissie Breed Welzijn Maastricht aan de GGD-zzl. Inhoud: rondleidingen en presentaties over diensten van de GGD.

Presentatie van voortgang Hartslag Limburg in Raadscommissie welzijn \& volksgezondheid van gemeente Valkenburg. (powerpoint presentatie) Nota Lokaal Gezondheidsbeleid 2003 - 2007. Gemeentelijke verantwoordelijkheden in de openbare gezondheidszorg op basis van de Wet Collectieve Preventie Volksgezondheid. Gemeente Maastricht, pp 17-18.

Emailbericht van ambtenaar Maastricht aan GGD-medewerkers. Inhoud: laatste versie van nota lokaal gezondheidsbeleid en aankondiging zwangerschapsverlof

Notulen Dagelijks Bestuur, GGD Zuidelijk Zuid-Limburg

Verslag hoofdenoverleg van NHG; akkoord met notitie over preventiebeleid waarin opgenomen een vervolgtraject op Hartslag Limburg

Presentatie van voortgang Hartslag Limburg in Raadscommissie welzijn \& volksgezondheid van gemeente Meerssen. (powerpointpresentatie)

Prudon P, Lautenbach T. Ruland E, Stappers J. Beleidsplan functie gezondheidsadviseur/zorgcoördinator. GGD/afdeling Cardiologie azM

Presentatie van voortgang Hartslag Limburg in Raadscommissie welzijn

\& volksgezondheid van gemeente Margraten. (powerpointpresentatie) Dagboekaantekeningen betreffende de mondelinge reacties van raadsle- 
den en telefonische contacten die hieruit volgen.

Emailberichten betreffende de vervolgcontacten met raadsleden en ambtenaren.

D68 05.06.2003 Notulen overleg managementteam GGD-zzl. Er wordt gesignaleerd dat er nog discrepantie zou bestaan tussen GGD strategienota en de nota volks gezondheid van de gemeente Maastricht. Staflid zegt de raadsvergadering hierover te zullen bijwonen.

D69 16.06.2003 Dagboeknotitie. Verslag van staflid GGD van de raadscommissie Breed Welzijn van Maastricht. Inhoud: advisering door de raadscommissie aan de raad over de nota Lokaal gezondheidsbeleid.

D70 17.06.2003 Dagboekaantekening. Bezoek van de Algemene Rekenkamer aan project leider Hartslag (vragenlijst en interview tbv rapport "Preventieve gezondheidszorg")

D71 18.06.2003 Persbericht GGD Nederland in reactie op het Rapport IGZ Algemeen Toezicht bij de GGD, van 17.06.2003

D72 18.06.2003 Memo van projectleider Hartslag Limburg aan AB GGD. Inhoud: continuering financiering Hartslag Limburg

D73 19.06.2003 Email van medewerker Hartslag Limburg aan projectleider met verslag van bijeenkomst raadscommissie Margraten dd. 04.06 .2003

D74 26.06.2003 Intern nieuwsbericht aan medewerkers van de drie Zuid-Limburgse GGD'en over de aankondiging van de fusie

D75 Juli 2003 Uitgave van Nieuwsbrief 6 van Hartslag Limburg. Inhoud: presentatie van activiteiten, onderzoeksresultaten en ontvangst nationale Stimuleringsprijs Openbare Gezondheidszorg.

D76 03.07.2003 Notulen Dagelijks Bestuur, GGD Zuidelijk Zuid-Limburg

D77 03.07.2003 Notulen Algemeen Bestuur, GGD Zuidelijk Zuid-Limburg

D78 03.07.2003 “Tussenrapportage Bezuinigen=Kiezen”, college van B\&W Maastricht voor de gecombineerde raadscommissie Algemene Zaken/Middelen dd. 9 juli 2003, pag 12.

D79 04.07.2003 Email van hoofd financiën van de GGD-zzl aan MT van de GGD-zzl. Inhoud: "het budget dat Trajekt van de gemeente krijgt, zijnde $€ 90.000$, wordt naar de GGD gesluist."

D80 09.07.2003 Dagboeknotities intern overleg tussen projectleider Hartslag, hoofd financiën, clustercoördinator. Inhoud: door afdeling financiën zijn veel te hoge kosten betreffende financiering Hartslag naar gemeenten toe opgevoerd. Dit moet zo snel mogelijk gecorrigeerd worden.

D81 10.07.2003 Notulen overleg GGD-azM t.b.v. implementatie van gezondheidsadviseurs van Hartslag binnen plannen voor Hart en Vaat Centrum van azM.

D82 11.07.2003 Notulen Dagelijks Bestuur, GGD Zuidelijk Zuid-Limburg

D83 11.07.2003 Emailbericht van directeur Trajekt aan projectleider Hartslag en brief van directeur Trajekt aan eigen personeel. Inhoud van beide: in de gemeentelijke bezuinigingsvoorstellen wordt de bijdrage van Trajekt aan het Hartslag Limburg stopgezet.

Emailbericht van projectleider aan directeur GGD en anderen: duidelijke stellingname is vereist.

D84 16.07.2003 Gemeente Margraten: perspectiefnota voor de begroting 2004.

Vermelding van Hartslag Limburg op p.2.

D85 Aug. 2003 Nota Lokaal Gezondheidsbeleid 2003 - 2007. Gemeentelijke verantwoordelijkheden in de openbare gezondheidszorg op basis van de Wet 
Collectieve Preventie Volksgezondheid. Gemeente Valkenburg aan de Geul, pp. 16-17.

D86 02.09.2003 Emails en dagboeknotities betreffende contact tussen projectleider 15.09.2003 Hartslag en directeur Trajekt

D87 08.09.2003 Brief (kenmerk mj/mr) vanuit GGD aan wethouder Sportzaken n.a.v. discussienota "Kiezen voor sport".

D88 10.09.2003

Notulen Dagelijks Bestuur, GGD Zuidelijk Zuid-Limburg

D89 10.09.2003 Commentaar VNG en GGD Nederland op concept preventienota VWS (tekst persbericht op 10.09.03; samenvatting speech Wim Kuiper lid directieraad VNG tgv debat OGZ)

D90 12.09.2003 Conceptversie 7 van preventienota VWS Langer gezond leven, waarin vermelding van Hartslag Limburg (p.12 en 49)

D91 16.09.2003 Ledenbericht GGD Nederland met bericht over certificeringstraject dat uitgevoerd gaat worden door stichting HKZ

D92 17.09.2003 Emailbericht van staf GGD naar gemeente ambtenaren en Riagg. Inhoud: doorspelen van concept preventienota van VWS met daarin vermeldingen van Hartslag Limburg.

D93 23.09.2003 Notulen Managementteam GGD-zzl. Onderwerp is o.a. de moeizame voortgang van het productenboek en de productbegroting van de GGD-zzl

D94 25.09.2003 Emailbericht van staf GGD naar directie en staf azM. Inhoud: doorspelen van concept preventienota van VWS met daarin vermeldingen van Hartslag Limburg look het cardiologisch deel).

D95 29.09.2003 Notulen vergadering Raadscommissie Breed Welzijn gemeente Maastricht.

D96 01.10.2003 Verslag van de thema avonden (22 en 29 sept.) over het nieuwe sportbeleid van de gemeente Maastricht

D97 02.10.2003 Dagboeknotitie. Verslag crisisberaad projectleider Hartslag Limburg en directeur GGD.

D98 03.10.2003- Emailwisselingen tussen medewerkers GGD, Traject en ambtenaren. 08.10.2003 Inhoud: zoeken naar oplossingen voor dreigende bezuiniging. Dagboeknotities over dezelfde inhoud.

D99 10.10.2003 Interne memo van projectleider Hartslag aan staf en communicatiemedewerker plus emailberichten. Inhoud: Voorstel van projectleider om een nieuwsbrief uit te brengen. Initiatief wordt door directeur afgewezen, de materie zou te gevoelig liggen bij bestuursleden.

D100 11.10.2003 “Gemeente Eijsden wil bezuinigingen verder doorvoeren." Verslag van financiële tekorten in de gemeente en de politieke druk op de wethouder (tevens portefeuillehouder van de GGD). In: Dagblad De Limburger

D101 13.10.2003 Dagboeknotitie. Inhoud: gesprek GGD directeur en projectleider Hartslag met wethouder Eijsden

D102 14.10.2003 Verslag van de Achtste vergadering van de gemeente raad van Maastricht (Gemeenteblad van Maastricht 2003). Agendapunt 6 betreft Programmabegroting 2004 (Raadsstuk 2003, volgnr. 102)

D103 15.10.2003 Informatiebijeenkomst van de GGD voor raadsleden en leden van het AB over het (concept) Productenboek 2004 van de GGD. Lijst van aanwezige personen. Powerpointpresentaties. Presentatie van "methode van Hartslag Limburg" als nieuwe standaard binnen wettelijk product GVO.

D104 21.10.2003 Nota Lokaal gezondheidsbeleid 2003 - 2007 van de gemeente Margraten. versie 1.10, dd. 21.10.2003. Inhoud: opname van Hartslag Limburg plus een activiteitenbudget voor een totaal van $€ 51.000$. 
D105 22.10.2003- Emailcontacten tussen GGD en ambtenaar Margraten. Inhoud: aanvullen28.10.203 de informatie over Hartslag t.b.v. de raadscommissie Welzijn

D106 29.10.2003 Dagboeknotitie. Verslag van overleg GGD-azM. Inhoud: Adj-dir. van azM benadrukt dat het azM een visie heeft op noodzakelijke vernieuwing, ondanks de bezuinigingen. In die visie pas de aanpak van Hartslag.

D107 05.11.2003 Emailcontact tussen VNG en projectleider Hartslag Limburg. VNG verzoekt om cijfers om landelijk lobby voor lokale projecten te kunnen voeren. Projectleider levert gegevens aan.

Email van projectleider naar directeur GGD om landelijke interesse voor Hartslag te benutten als argument naar gemeenten.

D108 12.11.2003 Brief van gemeente Valkenburg aan het Bestuur van de GGD-zzl (kenmerk: wau.03). "Betreft: voorstel tot aanpassing subsidies". Reden: gemeente meent dat kosten van Hartslag "fors gaan stijgen als gevolg van stopzetten van externe bijdragen".

D109 13.11.2003 Notulen overleg tussen GGD en Traject. Inhoud: zoeken naar oplossingen voor dreigende bezuiniging.

D110 17.11.2003 Commentaar VNG en GGD Nederland op preventienota VWS lbrief met kenmerk SEZ/2003004313, op 17.11.03 verzonden aan de vaste Kamercommissie)

D111 18.11.2003 Presentatie van voortgang Hartslag Limburg in Raadscommissie welzijn \& volksgezondheid van gemeente Eijsden. (powerpoint presentatie)

D112 19.11.2003 Emails van staflid GGD aan projectleider Hartslag en aan directeur GGD. Inhoud: ambtenaar van Maastricht gaf advies aan staf GGD om brandbrief vanuit de GGD uit te laten gaan richting de gemeente over de impact van de aangekondigde bezuiniging. Ambtenaren vinden dat deze bezuiniging niet had gemogen.

D113 19.11.2003 Persbericht van VNG, GGD Nederland en NIGZ tgv aanbieden van het 'Pleidooi voor extra investeren in gezonde jeugd'

D114 19.11.2003 Inspectie voor de gezondheidszorg. Rapport naar aanleiding van het algemeen toezichtbezoek aan de GGD Zuidelijk Zuid-Limburg. Maastricht, nov.2003

D115 20.11.2003 Algemene Rekenkamer. Rapport “Preventieve gezondheidszorg”. Den Haag, Algemene Rekenkamer.

Persbericht: "Aanpak van sociaal-economische gezondheidsverschillen urgent" (persbericht Algemene Rekenkamer)

D116 24.11.2003 Dagboekaantekeningen van intern overleg GGD-zzl. Projectleider, directeur en afdelingsmanagers bespreken de handelingsopties. Directeur geeft aan dat de fusie (en daarbinnen lopende financiële zorgen) momenteel zijn belangrijkste thema is. Besloten wordt twee brandbrieven uit te laten gaan: één vanuit de GGD en één vanuit de UM/azM-partners.

D117 27.11.2003 Emailbericht van clustermanager aan afdeling n.a.v. afspraken van overleg van 24.11.2003

D118 27.11.2003 Notulen Algemeen Bestuur, GGD Zuidelijk Zuid-Limburg

D119 28.11.2003 Brief van de UM (kenmerk NdV/hh 03-90; onderwerp: "noodkreet buurt gezondheidsbeleid") aan wethouder Maastricht (tevens bestuursvoorzitter van de GGD) door drie hoogleraren en een cardioloog met pleidooi voor behoud van Hartslag Limburg.

D120 Dec. 2003 'Samen Sterker', gezamenlijke uitgave van de drie Zuid-Limburgse GGD'en over de voortgang van de fusie 
D121 04.12.2003 Dagboeknotitie. Verslag crisisberaad projectleider Hartslag Limburg en directeur GGD.

D122 08.12.2003 Concept productbeschrijving van Hartslag Limburg t.b.v. Productenboek (aangepaste versie t.o.v. versie 15.10.2003)

D123 11.12.2003 Notulen Dagelijks Bestuur, GGD Zuidelijk Zuid-Limburg

D124 12.12.2003 Email van projectleider aan directeur GGD. Projectleider doet een drin gend beroep op directeur om brief van gemeente Valkenburg van 12.11.2003 te corrigeren.

Brief van GGD directeur aan college B\&W Valkenburg (kenmerk er/mr; onderwerp: uw brief "voorstel tot aanpassing subsidies" van 12.11.2003) .

D125 15.12.2003 Emailbericht van directeur Trajekt aan portefeuillehouder Maastricht. Inhoud: directeur vraagt om duidelijkheid van gemeente en pleit voor Hartslag.

Emailreactie van portefeuillehouder: afspraak om z.s.m. een gezamenlijk overleg te organiseren tussen gemeenten, GGD en Trajekt

D126 22.12.2003 Brief van azM aan directie GGD. Bijlage: Contract Stimuleringsfonds Openbare Gezondheidszorg: koppeling preventie aan curatie; GGD-zzl en azM. (kenmerk BMB 03.102, dd. 18.12.2003)

D127 12.01.2004 Dagboek. Verslag van bijeenkomst GGD (directeur, projectleider), gemeente ambtenaren en Trajekt. Inhoud: kritiek op gemeenten over procesgang rond bezuinigingen op Hartslag. Ambtenaren zeggen toe te zoeken naar oplossingen. Vervolg op 17.02.2004.

D128 14.01.2004 Emailberichten tussen GGD en verpleegkundigen azM. Inhoud: notulen overleg met gezondheidsadviseurs azM om visie te ontwikkelen die aansluit bij de Werkgroep specialistisch verpleegkundigen van het azM.

D129 15.01 .2004 Notulen Dagelijks Bestuur, GGD Zuidelijk Zuid-Limburg

D130 23.01.2004 Brief van gemeente Valkenburg aan de lokale werkgroep van Hartslag. Inhoud: Gezien bezuinigingen en nog lopende plannen voor continuering in afgeslankte vorm is gemeente genoodzaakt de activiteiten van de werkgroep tot nader orde op te schorten.

D131 03.02.2004 Notulen oprichtingsbijeenkomst vakgroep Gezondheidsbevordering bij GGD Nederland

D132 10.02.2004 Interne nieuwsbrief van de drie Zuid-Limburgse GGD'en over de voortgang van de fusie

D133 10.02.2004 Presentatie van nieuwe structuur van de afdeling AGZ van de GGD t.b.v. de eigen medewerkers (powerpointpresentatie)

D134 12.02.2004 Persbericht NIGZ, VNG en GGD Nederland: "NIGZ, VNG en GGD Nederland dringen aan op sterker lokaal gezondheidsbeleid; Snelschrift over de preventienota"

D135 16.02.2004 Verslag van het nota-overleg van de vaste commissie voor VWS met de minister over het preventiebeleid. (vergaderjaar 2003-2004;22894, Preventiebeleid voor de volksgezondheid. nr22. motie Kant en nr.24 motie Tonkens)

D136 17.02.2004 Dagboeknotitie. Verslag van bijeenkomst GGD (directeur, projectleider), gemeente ambtenaren en Trajekt (vervolg van 12.01.2004). Inhoud: Gemeente Maastricht: geen extra middelen beschikbaar; gemeente wil het product ondanks de bezuinigingen gerealiseerd zien. GGD: de gemeente maakt geen duidelijke keuze:

D137 19.02.2004 Emailbericht van clustercoördinator GGD aan directeur, afdelingshoofd, 
projectleider en staf. 'Brandbrief' over dreigende afbouw van Hartslag Limburg

D138 19.02.2004 Notulen Dagelijks Bestuur, GGD Zuidelijk Zuid-Limburg

D139 19.02.2004 Dagboeknotitie. Verslag crisisberaad projectleider Hartslag Limburg, staf lid en directeur GGD.

D140 Mrt 2004 Ledenbericht GGD Nederland betreffende de benchmarkenquête

D141 01.03.2004 Dagboekaantekeningen intern overleg GGD betreffende productenboek; belangenstrijd tussen traditioneel erkende producten en innovatieproduct als Hartslag Limburg.

Concept productbeschrijving van Hartslag Limburg t.b.v. Productenboek (aangepaste versie t.o.v. versie 15.10.2003 en versie 08.12.2003)

D142 02.03.2004 Memo clustercoörinator aan directie en bestuur GGD-zzl. Brandbrief betreffende situatie Hartslag Limburg en de Gezondheidswijzer

D143 02.03.2004 Dagboeknotitie. Contacten met voorzitter raadscommissie gemeente Margraten

D144 08.03.2004 Emailbericht van staf aan projectleider Hartslag: agendapunt Hartslag Limburg is afgevoerd van de agenda van DB op 2 april. Reden: "verschillen in beeldvorming tussen ambtenaren, AB-leden en GGD-mensen".

D145 15.03.2004 Email van staf GGD. Betreft uitnodiging voor 1 april overleg DB, ambtenaren en GGD-betrokkenen over Hartslag Limburg

D146 16.03.2004 Email van staf GGD aan projectleider Hartslag t.a.v. overleg 1 april (zie hierboven): "de bestuursvoorzitter heeft alles weer afgeblazen".

D147 16.03.2004 Dagboeknotitie. Verslag van raadscommissie Breed Welzijn Maastricht van 15.03.2004.

D148 24.03.2004 Brief van de gemeente Eijsden aan het DB van de GGD Zuidelijk ZuidLimburg. Inhoud: gemeente Eijsden wil niet buitenproportioneel gaan bijdragen aan Hartslag.

D149 24.03.2004 Notulen van de vergadering van de commissie Welzijn van de gemeente Margraten

D150 25.03.2004 Emailbericht van projectleider Hartslag aan ambtenaren gemeente Maastricht en Valkenburg. Inhoud: verzoek om behalve via formele weg langs de GGD directeur ook directe te communiceren over evt. "kritiek op Hartslag'.

D151 29.03.2004 Dagboeknotitie. Intern verslag van clustercoördinator GGD aan projectleider Hartslag. Inhoud: Pogingen van de directeur om Hartslag elementen een prominentere rol in het Productenboek te geven zouden zijn stukgelopen op de houding van ambtenaar en wethouder Maastricht.

D152 30.03.2004 Agenda GVO overleg GGD-zzl. Betreft o.a.: notitie Productgroep Gezondheidsbevordering

D153 30.04.2004 Dagboekaantekeningen: telefonisch overleg met ambtenaar Margraten; inhoud: feedback t.b.v. optimale presentatie Hartslag t.b.v. gemeente Margraten

D154 April 2004 'Samen Sterker', gezamenlijke uitgave van de drie Zuid-Limburgse GGD'en over de voortgang van de fusie

D155 01.04.2004 Memo plus emailberichten van projectleider Hartslag Limburg aan ambtenaar gemeente Margraten. Inhoud: aanvullende rapportage over activiteiten, kosten en resultaten, gespecificeerd t.b.v. de raadscommissie van gemeente Margraten

D156 13.04.2004 Emailbericht van GGD aan gemeente Maastricht. Inhoud: "Maastricht met 
gezondheidsproject mogelijk in het landelijk nieuws".

Dagboekaantekening: telefonisch contact tussen projectleider Hartslag en Volkskrant redacteur over methode om Hartslag op voorpagina te krijgen.

D157 14.04.2004 Emailbericht van projectleider Hartslag aan redacteur van de Volkskrant. Inhoud: powerpointpresentaties en documenten met resultaten van Hartslag Limburg die de volgende dag op het Nationale Congres Volksgezondheid te Rotterdam gepresenteerd zullen worden.

D158 14.04.2004 Memo projectleider Hartslag Limburg t.b.v gemeente Margraten. Inhoud: verantwoording activiteiten Werkgroep Margraten van Hartslag Limburg.

D159 15.04.2004 Persbericht van GGD: "Resultaten Maastrichts project: gewichtsstijging is met preventie af te remmen.

Artikel op voorpagina van de Volkskrant: 'Ongezonde' regio is er na campagne stuk beter aan toe.

Presentatie van resultaten Hartslag Limburg op workshop van Nationale Congres Volksgezondheid te Rotterdam (powerpoinpresentaties)

D160 15.04.2004 Notulen Dagelijks Bestuur, GGD Zuidelijk Zuid-Limburg

D161 15.04.2004 Notulen Algemeen Bestuur, GGD Zuidelijk Zuid-Limburg

D162 16.04.2004 Artikel in Dagblad De Limburger: "Bevorderen gezonde levensstijl is zinvol".

D163 20.04.2004 Emailcontacten tussen projectleider Hartslag en voorzitter van de raadscommissie Margraten. Inhoud: aanleveren van 'harde cijfers'.

D164 21.04.2004 Ministerie van Binnenlandse Zaken. Samenwerken aan de Krachtige stad; Uitwerking van het stelsel Grotestedenbeleid 2005-2009 (GSBIII). Den Haag, min BiZa.

D165 21.04.2004 Presentatie door GGD van Hartslag Limburg op bijeenkomst raadscommissie Welzijn gemeente Margraten.

Dagboekaantekeningen betreffende reacties van raadsleden.

D166 23.04.2004 Emailbericht van voorzitter raadscommissie aan projectleider Hartslag.

D167 27.04.2004 Ledenbericht GGD Nederland: akkoord tussen G-30 en het Rijk betreffen de grotestedenbeleid 2005-2009 (GSBIII)

D168 10.05.2004 Emailverkeer tussen staflid GGD en ambtenaren van gemeente Maastricht. Inhoud: Vruchteloze poging van staflid GGD om via GSB-3 geldstroom van de gemeente Maastricht financiering te verwerven voor de Hartslag werkwijze onder verwijzing van GSB kader voor jeugd, overgewicht en SEGV. GSB budget blijkt flink gekrompen.

D169 11.05.2004 Notulen van de raadsvergadering van de gemeente Margraten. Inhoud: besluit van de raad om de nota Lokaal gezondheidsbeleid 2003-2007 vast te stellen, met een budget voor Hartslag Limburg van $€ 48.000$.

D170 13.05.2004 Notulen Dagelijks Bestuur, GGD Zuidelijk Zuid-Limburg

D171 19.05.2004 Notulen Dagelijks Bestuur, GGD Zuidelijk Zuid-Limburg

D172 02.06 .2004

D173 21.06.2004 Artikel Dagblad De Limburger “Wethouder M opgestapt” en redactioneel commentaar

D174 Juli 2004 Notulen Dagelijks Bestuur, GGD Zuidelijk Zuid-Limburg Artikel in Mediaan, huisblad van UM en azM. Jaargang 6, juli 2004, pp 1213. Titel: "Hartslag Limburg krijgt vervolg in Hartslag 2"

D175 $\quad 01.07 .2004$ Notulen Algemeen Bestuur, GGD Zuidelijk Zuid-Limburg

D176 $\quad 01.07 .2004$ Begroting 2005 GGD-ZZL. Vastgesteld door Algemeen Bestuur

D177 22.07.2004 Notulen Dagelijks Bestuur, GGD Zuidelijk Zuid-Limburg

D178 22.07.2004 Memo van directie aan alle medewerkers. Inhoud: ernstige tekorten.

D179 Sept. 2004 Artikel in Select, huisblad van UM en azM, special over het Hart en Vaat 
Centrum. Jaargang 12, sept. 2004, pp 7-8. "Hartslag 2"

Mondelinge presentatie van Hartslag 2 in het azM

$\begin{array}{lll}\text { D180 } & 16.09 .2004 & \text { Notulen Dagelijks Bestuur, GGD Zuidelijk Zuid-Limburg } \\ \text { D181 } & 29.09 .2004 & \text { Brief met bijlagen van de directeur GGD aan de Stichting }\end{array}$

Strouven te Maastricht. Onderwerp: subsidieverzoek met betrekking tot community-deel van Hartslag LImburg

D182 30.09.2004 Interne nieuwsbrief van de drie Zuid-Limburgse GGD'en over de voortgang van de fusie

D183 07.10.2004 Interne nieuwsbrief van de drie Zuid-Limburgse GGD'en over de voortgang van de fusie

D184 08.10.2004 Intern nieuwsbericht van de GGD-directeur, getiteld "veranderingen worden duidelijker en zichtbaar". Inhoud: samenwerking GGD, gemeenten en NIGZ met als invulling vroegere Hartslag en schoolSlag verbreden naar fusiepartners in Zuid-Limburg.

D185 $\quad 14.10 .2004$ Brief van Stichting Elisabeth Strouven te Maastricht aan GGD. Inhoud: afwijzing subsidieverzoek.

D186 21.10.2004 Notulen Dagelijks Bestuur, GGD Zuidelijk Zuid-Limburg

D187 08.12.2003 Brief van VWS aan ZonMw met verzoek om een programma academische werkplaatsen openbare gezondheidszorg te starten (bericht via GGD Kennisnet)

D188 11.11.2004

D189 Dec. 2004

D190 16.12.2004

D191 16.12.2004

D192 20.01.2005

D193 20.01.2005

D194 27.01.2005 D195 22.02.2005

D196 17.03 .2005

D197 12.04.2005

D198 21.04.2005

D199 26.04.2005

D200 19.05.2005

D201 31.05.2005

D202 Mei 2005

D203 13.06.2005

D204 16.06.2005

D205 16.06.2005

D206 22.06.2005
Notulen Dagelijks Bestuur, GGD Zuidelijk Zuid-Limburg

Interne nieuwsbrief van de drie Zuid-Limburgse GGD'en over de voortgang van de fusie

Notulen Dagelijks Bestuur, GGD Zuidelijk Zuid-Limburg

Notulen Algemeen Bestuur, GGD Zuidelijk Zuid-Limburg

“Gezondheidsbevordering in lokaal perspectief". Convenant VNG, GGD

Nederland, NIGZ. Den Haag, Woerden, Utrecht.

Presentatie van resultaten Hartslag Limburg (powerpointpresentatie).

Presentatie t.b.v. 4e Nationale Congres Gezondheidsbevordering te Papendal

Notulen Dagelijks Bestuur, GGD Zuidelijk Zuid-Limburg

Productenboek 2005 GGD-zzl. Producten Gezondheidsbevordering; ingekocht door de gemeenten Maastricht, Margraten, Meerssen, Valkenburg en Eijsden. Maastricht, GGD-zzl

Notulen Dagelijks Bestuur, GGD Zuidelijk Zuid-Limburg

Dagboeknotitie. Inhoud: verslag van staflid GGD betreffende presentatie resulaten Hartslag Limburg voor AB.

Notulen Dagelijks Bestuur, GGD Zuidelijk Zuid-Limburg

Interne nieuwsbrief van de drie Zuid-Limburgse GGD'en over de voortgang van de fusie

Notulen Dagelijks Bestuur, GGD Zuidelijk Zuid-Limburg

Interne nieuwsbrief van de drie Zuid-Limburgse GGD'en over de voortgang van de fusie

7e Nieuwsbrief Hartslag Limburg. Inhoud: o.a. resultaten op effect- en kosteneffectiviteitsniveau uit onderzoek RIVM en UM

Interne nieuwsbrief van de drie Zuid-Limburgse GGD'en over de voortgang van de fusie

Notulen Dagelijks Bestuur, GGD Zuidelijk Zuid-Limburg

Notulen Algemeen Bestuur, GGD Zuidelijk Zuid-Limburg

Intentieverklaring samenwerking tussen NIGZ en regio Zuid-Limburg 
(gemeenten en GGD'en). Woerden, NIGZ

D207 Juli 2005 ZonMw, trendwatcher of amoebe? Interview met Hans de Goeij, in:

Prepost, ZonMW, juli 2005, jaargang 7, nummer 21, p. 5-7

D208 14.07.2005 Interne nieuwsbrief van de drie Zuid-Limburgse GGD'en over de voortgang van de fusie (met o.a voortgang academisering en convenant met het NIGZ)

D209 19.07.2005 Email bericht van de GGD directeur aan alle medewerkers waarin hij zijn vertrek per 1 augustus aankondigt en kort verslag doet van de belangrijkste gebeurtenissen in zijn tweejarige periode

D210 15.09.2005 Notulen Dagelijks Bestuur, GGD Zuidelijk Zuid-Limburg

D211 25.10.2005 Programma werkconferentie NIGZ, GGD'en en gemeenten in ZuidLimburg t.g.v. ondertekening Samenwerkingsconvenant NIGZ en regio Zuid-Limburg (incl. persbericht en tekst convenant)

D212 27.10.2005 Notulen Dagelijks Bestuur, GGD Zuidelijk Zuid-Limburg

D213 GGD Zuidelijk Zuid-Limburg (2004). Gemeenschappelijke Regeling GGD Zuidelijk Zuid-Limburg. Maastricht, respectievelijk artikel 16.1, 19.1 en 20.3. 


\section{Bijlage 1}

Tabel: Factoren en veronderstellingen behorend bij het theoretisch model voor bestuurlijke verankering van regionale samenwerking (naar: Werkgroep Integrale Zorg, capgroep BEO Z, U M ); uiteindelijke versie behorend bij figuur 7.1. 


\begin{tabular}{|c|c|c|c|}
\hline Dimensies & Factoren & Indicatoren & Veronderstellingen/definities \\
\hline \multirow[t]{2}{*}{ 1. Externe factoren } & $\begin{array}{l}\text { a) Beleid en regelgeving } \\
\text { van de overheid }\end{array}$ & $\begin{array}{l}\text { - Wetgeving: WCPV (WMO) } \\
\text { - Nationaal Contract } \\
\text { Openbare Gezondheidszorg } \\
\text { - Nota's VWS } \\
\text { - Dualisme in de lokale poli- } \\
\text { tiek } \\
\text { - Huidig kabinetsbeleid } \\
\text { - Overige overheidsbeleid of } \\
\text { gebrek daaraan }\end{array}$ & $\begin{array}{l}\text { Gunstig is wanneer beleid, wet- en regelgeving helder } \\
\text { zijn en wanneer inhoud en vorm van de samenwerking } \\
\text { geëxpliciteerd zijn in meerjarig gemeentelijk en regio- } \\
\text { naal gezondheidsbeleid. Ongunstig zijn het bestaan van } \\
\text { financieringsschotten, de schaarste aan middelen en het } \\
\text { streven naar marktwerking (leidt tot concurrentiegevoe- } \\
\text { lens). }\end{array}$ \\
\hline & $\begin{array}{l}\text { b) Beleid en regels van } \\
\text { financiers }\end{array}$ & $\begin{array}{l}\text { - Oordeel over de mate waar- } \\
\text { in de samenwerking past } \\
\text { binnen actueel beleid en } \\
\text { regelgeving } \\
\text { - Oordeel over de mate waar- } \\
\text { in financiers meedenken } \\
\text { - Oordeel over flexibiliteit in } \\
\text { de toepassing van financie- } \\
\text { ringsregels }\end{array}$ & $\begin{array}{l}\text { Om het samenwerkingsproces niet te frustreren moeten } \\
\text { het beleid en de procedures van 'financiers op afstand' } \\
\text { meedenkend, ondersteunend en stimulerend zijn, en } \\
\text { moet de financiering van de samenwerking over een vol- } \\
\text { doende lange periode gegarandeerd zijn om personele } \\
\text { leegloop te voorkomen. }\end{array}$ \\
\hline \multirow[t]{2}{*}{ 2. Lokale context } & $\begin{array}{l}\text { a) Bestaande samenwer- } \\
\text { kings-relaties }\end{array}$ & $\begin{array}{l}\text { - Intensiteit van samenwer- } \\
\text { kingsrelatie } \\
\text { - Oordeel over samenwer- } \\
\text { kingsrelatie }\end{array}$ & $\begin{array}{l}\text { Wanneer partijen (organisaties en individuen) reeds naar } \\
\text { tevredenheid met elkaar samenwerken, hebben zij het } \\
\text { proces van onderlinge kennismaking en het kweken van } \\
\text { vertrouwen grotendeels achter de rug. Zij kunnen sneller } \\
\text { aan een nieuw initiatief werken en hebben voorsprong op } \\
\text { anderen zonder samenwerkingrelaties. }\end{array}$ \\
\hline & $\begin{array}{l}\text { b) Kenmerken van } \\
\text { bedrijfsvoering }\end{array}$ & $\begin{array}{l}\text { - Aanwezigheid ingrijpende } \\
\text { veranderingsprocessen } \\
\text { - Fusie } \\
\text { - Verbouwing en/of verhuizing } \\
\text { - Te krappe huisvesting } \\
\text { - Financiële tekorten }\end{array}$ & $\begin{array}{l}\text { Naarmate partijen meer worden geconfronteerd met ont- } \\
\text { wikkelingen en problemen die voor de eigen organisatie } \\
\text { belangrijk zijn (zoals het overheidsbeleid, budgettekorten, } \\
\text { fusieprocessen) zal de motivatie om te werken aan een } \\
\text { verankering van de samenwerking lager zijn. Deze ontwik- } \\
\text { kelingen en problemen eisen namelijk veel aandacht op. }\end{array}$ \\
\hline
\end{tabular}




\begin{tabular}{|c|c|c|c|}
\hline Dimensies & Factoren & Indicatoren & Veronderstellingen/definities \\
\hline \multirow[t]{3}{*}{$\begin{array}{l}\text { 2. Lokale context } \\
\text { (vervolg) }\end{array}$} & & $\begin{array}{l}\text { - Personele problemen } \\
\text { - Andere ontwikkelingen }\end{array}$ & \\
\hline & c) Belangenstrijd actoren & $\begin{array}{l}\text { - Kostenverhogende ambities } \\
\text { versus kostenbeheersende } \\
\text { verantwoordelijkheden } \\
\text { - Inhoudelijke samenwer- } \\
\text { kingsvoordelen versus } \\
\text { inperking macht van 'beslis- } \\
\text { sers' } \\
\text { - Concurrentie om beperkte } \\
\text { middelen } \\
\text { - Carrièrekansen of juist risi- } \\
\text { co op afbreuk } \\
\text { - Wetenschappelijke eisen } \\
\text { versus praktische belangen } \\
\text { - Korte termijn versus lange } \\
\text { termijn belangen }\end{array}$ & $\begin{array}{l}\text { Naarmate individuele actoren meer betrokken zijn met } \\
\text { rationele en/of irrationele belangen die strijdig zijn met } \\
\text { belangen van andere actoren (zoals eigen voorkeuren en } \\
\text { strevingen, eventueel los van formeel beleid van de eigen } \\
\text { organisatie) zal de motivatie om te werken aan een ver- } \\
\text { ankering van de samenwerking lager zijn. }\end{array}$ \\
\hline & d) Regierol gemeenten & $\begin{array}{l}\text { - Herkenbare gemeentelijke } \\
\text { visie } \\
\text { - Consequente vertaling van } \\
\text { visie in prioriteiten } \\
\text { - Vaststellen van benodigde } \\
\text { middelen } \\
\text { - Benutten van gemeentelijke } \\
\text { autoriteit }\end{array}$ & $\begin{array}{l}\text { De regierol van gemeenten betreft een bijzondere vorm } \\
\text { van sturen die is gericht op de afstemming van actoren, } \\
\text { hun doelen en handelingen tot een meer samenhangend } \\
\text { geheel, met het oog op een bepaald resultaat. Deze regie- } \\
\text { voering vereist een duidelijke gemeentelijke visie, die ver- } \\
\text { taald wordt in een politiek-bestuurlijke en ambtelijke prio- } \\
\text { riteitstelling, evenals het vaststellen van de daarvoor } \\
\text { benodigde en beschikbare gemeentelijke middelen. } \\
\text { Daarentegen wordt gebrek aan regierol gekenmerkt door } \\
\text { het vermijden van besluitvorming over politiek-bestuur- } \\
\text { lijke en ambtelijke prioriteiten, het negeren van verant- } \\
\text { woordelijkheid voor het vaststellen van benodigde mid- } \\
\text { delen en het ongebruikt laten van autoriteit. }\end{array}$ \\
\hline
\end{tabular}




\begin{tabular}{|c|c|c|c|}
\hline Dimensies & Factoren & Indicatoren & Veronderstellingen/definities \\
\hline \multirow[t]{3}{*}{ 3. Verander-management } & $\begin{array}{l}\text { a) Visie: ontwerp en doel- } \\
\text { stellingen }\end{array}$ & $\begin{array}{l}\text { - Aangereikte informatie over } \\
\text { het belang en de opzet van } \\
\text { de samenwerking }\end{array}$ & $\begin{array}{l}\text { Om aan te sluiten bij het oordeel en belang van actoren } \\
\text { dient het projectontwerp overtuigend te zijn in vergelij- } \\
\text { king tot alternatieven (o.a.. evidence-based, practice- } \\
\text { based, doelgroep gericht en patient-based). Om win-win } \\
\text { te creëren moet het ontwerp aansluiten bij bestaand } \\
\text { beleid en belangen. Om de voortgang te kunnen evalue- } \\
\text { ren moeten de doelen volgens SMART principes gefor- } \\
\text { muleerd worden: specifiek, meetbaar, acceptabel, realis- } \\
\text { tisch en tijdgebonden. }\end{array}$ \\
\hline & $\begin{array}{l}\text { b) Sociaal entrepreneur- } \\
\text { schap }\end{array}$ & $\begin{array}{l}\text { - Contacten leggen om zicht- } \\
\text { bare en onzichtbare actoren } \\
\text { (of meningen) te identifice- } \\
\text { ren } \\
\text { - Beleggen van bijeenkom- } \\
\text { sten met actoren }\end{array}$ & $\begin{array}{l}\text { Om een window of opportunity te creëren moet een soci- } \\
\text { aal entrepreneur de drie stromingen van mensen en } \\
\text { ideeën bij elkaar brengen die de bestuurlijke agenda's } \\
\text { beïnvloeden: problemen, oplossingen en bestuurlijke } \\
\text { gebeurtenissen. De entrepreneur identificeert de zicht- } \\
\text { bare en onzichtbare actoren in dit proces en lobbyt voor } \\
\text { kansrijke alternatieven m.b.v. verschillende beïnvloe- } \\
\text { dingsstrategieën. }\end{array}$ \\
\hline & $\begin{array}{l}\text { c) Beïnvloedings- strate- } \\
\text { gieën: } \\
\text { 1. Machtsstrategieën } \\
\text { 2 Positieve feedback } \\
\text { 3. Imago ontwikkeling }\end{array}$ & $\begin{array}{l}\text { - Inzetten van (uitingen van) } \\
\text { coalities } \\
\text { - Inzet van geld of andere } \\
\text { incentives } \\
\text { - Inzet van eigen communica- } \\
\text { tiemiddelen: nieuwsbrief, } \\
\text { professionele publicaties } \\
\text { - Realiseren van massame- } \\
\text { diale uitingen en free publi- } \\
\text { city }\end{array}$ & $\begin{array}{l}\text { Draagvlak voor samenwerking kan versterkt worden } \\
\text { door beïnvloedingsstrategieën: machtsstrategieën, posi- } \\
\text { tieve feedback en imago ontwikkeling. Machtsstrategieën } \\
\text { betreffen het toepassen van een coalitie als drukmiddel } \\
\text { en de inzet van geld of andere incentives, op basis van de } \\
\text { identificatie van actoren en hun belangen. Communicatie } \\
\text { van vooruitgang en successen (positieve feedback) wordt } \\
\text { gecombineerd met de opbouw van een positief imago via } \\
\text { massamediale uitingen. }\end{array}$ \\
\hline
\end{tabular}




\begin{tabular}{|c|c|c|c|}
\hline Dimensies & Factoren & Indicatoren & Veronderstellingen/definities \\
\hline \multirow[t]{2}{*}{$\begin{array}{l}\text { 3. Verander-management } \\
\text { (vervolg) }\end{array}$} & d) Netwerk ontwikkeling & $\begin{array}{l}\text { - Frequentie van contacten } \\
\text { met actoren buiten de eigen } \\
\text { organisatie } \\
\text { - Concrete afspraken of ini- } \\
\text { tiatieven die met andere } \\
\text { actoren worden gereali- } \\
\text { seerd }\end{array}$ & $\begin{array}{l}\text { De toepassing van verandermanagement vereist actuele } \\
\text { en informele informatie vanuit verschillende lagen bin- } \\
\text { nen organisaties. De opbouw van een voldoende groot } \\
\text { netwerk verschaft toegang tot deze informatie. Barrières } \\
\text { tussen organisaties kunnen overbrugd worden door per- } \\
\text { sonen die als tussenschakels functioneren. }\end{array}$ \\
\hline & $\begin{array}{l}\text { e) Leiderschap } \\
\text { (vanuit de GGD) }\end{array}$ & $\begin{array}{l}\text { - Het formuleren van doelen } \\
\text { en daarvoor benodigde tus- } \\
\text { senstappen } \\
\text { - Het consequent inzetten van } \\
\text { de eigen autoriteit in de } \\
\text { richting van de uitgezette } \\
\text { koers } \\
\text { - Gerichtheid op verandering } \\
\text { - In staat om kernwaarden te } \\
\text { formuleren en te demon- } \\
\text { streren in voorbeeld gedrag } \\
\text { - Het kunnen inspireren en } \\
\text { motiveren van anderen } \\
\text { (overtuigingskracht) }\end{array}$ & $\begin{array}{l}\text { Leiderschap vanuit de GGD is een wederzijds beïnvloe- } \\
\text { dende relatie tussen de directeur en andere actoren, } \\
\text { gericht op het bereiken van tastbare resultaten die pas- } \\
\text { sen binnen de met gemeenten en derden gedeelde } \\
\text { gemeenschappelijke doelen. De aanwezigheid van leider- } \\
\text { schap wordt gekenmerkt door het formuleren van doelen } \\
\text { en daarvoor benodigde tussenstappen en het consequent } \\
\text { inzetten van de eigen autoriteit in de richting van de uit- } \\
\text { gezette koers. } \\
\text { Daarentegen wordt gebrek aan leiderschap gekenmerkt } \\
\text { door het vermijden van actie en besluitvorming, het } \\
\text { negeren van verantwoordelijkheid en het ongebruikt } \\
\text { laten van de professionele autoriteit. }\end{array}$ \\
\hline $\begin{array}{l}\text { 4. Determinanten } \\
\text { van draagvlak }\end{array}$ & a) Doelstelling & $\begin{array}{l}\text { - Mate van belangrijkheid van } \\
\text { doelen } \\
\text { - Mate van belangrijkheid om } \\
\text { daar d.m.v. samenwerking } \\
\text { aan te werken }\end{array}$ & $\begin{array}{l}\text { Voor een goed draagvlak onder partijen moeten individu- } \\
\text { ele participanten achter het samenwerkingsdoel staan } \\
\text { (gemeenschappelijke visie t.a.v. wederzijdse afhankelijk- } \\
\text { heid voor doelbereiking). }\end{array}$ \\
\hline
\end{tabular}




\begin{tabular}{|c|c|c|c|}
\hline Dimensies & Factoren & Indicatoren & Veronderstellingen/definities \\
\hline \multirow[t]{4}{*}{$\begin{array}{l}\text { 4. Determinanten } \\
\text { van draagvlak } \\
\text { (vervolg) }\end{array}$} & b) Belang & $\begin{array}{l}\text { - Oordeel over mate waarin } \\
\text { de samenwerking bijdraagt } \\
\text { aan het bereiken van de } \\
\text { doelen } \\
\text { - Oordeel over prioritering } \\
\text { van de samenwerking bin- } \\
\text { nen de eigen organisatie }\end{array}$ & $\begin{array}{l}\text { Bovendien moet dit doel aansluiten bij hun eigen doelen } \\
\text { en moet de samenwerking van belang worden geacht } \\
\text { voor de eigen organisatie. }\end{array}$ \\
\hline & c) Win-win situatie & $\begin{array}{l}\text { - Oordeel over de balans tus- } \\
\text { sen voor- en nadelen van de } \\
\text { samenwerking voor de } \\
\text { eigen organisatie }\end{array}$ & $\begin{array}{l}\text { Voor een goed draagvlak onder partijen moeten individu- } \\
\text { ele participanten het gevoel hebben dat aan (blijvende) } \\
\text { deelname meer voordelen dan nadelen vastzitten. }\end{array}$ \\
\hline & $\begin{array}{l}\text { d) Consensus: } \\
\text { Domeinconsensus en } \\
\text { Ideologische consensus }\end{array}$ & $\begin{array}{l}\text { - Respect voor ieders identi- } \\
\text { teit } \\
\text { - Overeenstemming over rol- } \\
\text { len, taakafbakening, regie- } \\
\text { rol } \\
\text { - Overeenstemming over } \\
\text { focus op kwetsbare groepen }\end{array}$ & $\begin{array}{l}\text { Het bestaan van overeenstemming over elkaars taken, } \\
\text { functies, werkwijze en werkgebied (domeinconsensus) } \\
\text { en overeenkomsten in cultuur, zoals visie op samenwer- } \\
\text { king, het belang van preventie, het gewenste lokale pre- } \\
\text { ventieaanbod en het aansluiten op lokale behoeften (ide- } \\
\text { ologische consensus), is een essentiële voorwaarde voor } \\
\text { een goed draagvlak onder partijen. }\end{array}$ \\
\hline & $\begin{array}{l}\text { e) Sense of urgency } \\
\text { ('urgentiebesef') }\end{array}$ & $\begin{array}{l}\text { - Congruentie tussen uitspra- } \\
\text { ken over 'belangrijkheid' en } \\
\text { 'dringendheid' van een item } \\
\text { enerzijds en handelingen } \\
\text { ter uitvoering van die inten- } \\
\text { tie anderzijds }\end{array}$ & $\begin{array}{l}\text { De aanwezigheid van een bewustzijn dat er snel en door- } \\
\text { tastend gehandeld dient te worden, hetgeen leidt tot de } \\
\text { prioriteit die partijen, ondanks andere belangen, geven } \\
\text { aan het gezamenlijke doel en de gezamenlijke afspra- } \\
\text { ken; in de casus de snelheid waarmee de besluitvorming } \\
\text { over bestuurlijke verankering gerealiseerd dient te wor- } \\
\text { den. }\end{array}$ \\
\hline
\end{tabular}




\begin{tabular}{|c|c|c|c|}
\hline Dimensies & Factoren & Indicatoren & Veronderstellingen/definities \\
\hline \multirow[t]{3}{*}{$\begin{array}{l}\text { 5. uitingsvormen } \\
\text { van draagvlak }\end{array}$} & a) Onderling vertrouwen & $\begin{array}{l}\text { - Oordeel over mate waarin } \\
\text { er sprake van een concur- } \\
\text { rentiesfeer } \\
\text { - Oordeel over of partners } \\
\text { competent zijn } \\
\text { - Oordeel of partners uit zijn } \\
\text { op eigen gewin }\end{array}$ & $\begin{array}{l}\text { Het accent van de onderlinge relaties kan op samenwer- } \\
\text { king of op concurrentie liggen. Wanneer het accent op } \\
\text { concurrentie ligt is dit een uiting van geringer onderling } \\
\text { vertrouwen, met als gevolg een lager draagvlak voor } \\
\text { samenwerking. }\end{array}$ \\
\hline & b) Betrokkenheid & $\begin{array}{l}\text { - Gezamenlijke planvorming } \\
\text { - Nakomen van afspraken } \\
\text { - Stappen zetten in procedu- } \\
\text { res die voorbereiden op de } \\
\text { inzet van mensen en midde- } \\
\text { len }\end{array}$ & $\begin{array}{l}\text { Door gezamenlijke planvorming, het nakomen van } \\
\text { afspraken en door het nemen van concrete voorbereidin- } \\
\text { gen die nodig zijn om te komen tot de inzet van middelen } \\
\text { (geld, personeel) tonen partijen hun betrokkenheid. }\end{array}$ \\
\hline & c) Adaptatie & $\begin{array}{l}\text { - Aanpassingen in de organi- } \\
\text { satie zoals: vast contactper- } \\
\text { soon, interne werkwijze, } \\
\text { taakverdeling, doelstellin- } \\
\text { gen of productie-afspraken }\end{array}$ & $\begin{array}{l}\text { Wanneer de samenwerking leidt tot innovatieve aanpas- } \\
\text { singen binnen de deelnemende organisatie, aanpassin- } \\
\text { gen gericht op het bevorderen van de samenwerking, } \\
\text { dan is dit een uitingsvorm van draagvlak voor implemen- } \\
\text { tatie. }\end{array}$ \\
\hline $\begin{array}{l}\text { 6. bestuurlijke } \\
\text { verankering }\end{array}$ & $\begin{array}{l}\text { a) Formalisatiegraad } \\
\text { b) Duurzaamheid } \\
\text { c) Inzet van middelen } \\
\text { d) Reikwijdte }\end{array}$ & $\begin{array}{l}\text { - Contracten, beleidsdocu- } \\
\text { menten } \\
\text { - Tijdsduur van de afspraken } \\
\text { - Menskracht en middelen } \\
\text { - Percentage van het potenti- } \\
\text { eel dat betrokken wordt }\end{array}$ & $\begin{array}{l}\text { Bestuurlijke verankering van samenwerking worden } \\
\text { gekenmerkt door expliciete afspraken tussen actoren op } \\
\text { vier aspecten, te weten: formalisatiegraad, duurzaam- } \\
\text { heid, inzet van middelen en reikwijdte. }\end{array}$ \\
\hline
\end{tabular}




\section{Dankwoord}

D it onderzoek kon niet tot stand komen zonder de steun van velen. Allereerst dank aan mijn promotoren en co-promotor. Jan, zonder jou was ik beslist nooit aan deze uitdaging begonnen. $\mathrm{H}$ et was onze jarenlange samenwerking die bij mij de ambitie deed ontwaken om de beoogde verankering van $\mathrm{H}$ artslag Limburg onderzoekbaar te maken. Behalve je niet aflatende steun en inspiratie wil ik je danken voor je warme vriendschap, je relativeringsvermogen en je niet aflatende vertrouwen. Cor, jij was voor mij het inhoudelijke anker. M et jouw scherpe analyse en de altijd nuttige suggesties toonde je mij wat een promotor in de ware zin van het woord kan betekenen. $\mathrm{H}$ eel veel dank hiervoor. Arno, jouw geduld en kritische blik op de ontelbare concepten gaven mij steeds het vertrouwen om weer een stap verder te komen. Altijd stond je open voor mijn vragen en binnen de kortst mogelijke tijd kreeg ik een reactie. In één woord: geweldig.

"Bij alle prestaties die wij verrichten is het goed om ons te realiseren dat wij altijd staan op de schouders van de generaties voor ons." D eze uitspraak van prof.dr. Jan van Ree geldt in sterke mate voor dit proefschrift. Dit, omdat de casus van mijn onderzoek, $\mathrm{H}$ artslag Limburg, bij uitstek een voorbeeld is van de samenwerking van vele organisaties en personen. $H$ et voert hier te ver om alle personen te noemen, maar zonder de betrokkenheid van de tientallen werkgroepleden, ambtenaren, welzijnswerkers, raadsleden, bestuurders, managers, huisartsen, cardiologen, verpleegkundigen, gezondheidsadviseurs, wetenschappers en G GD -medewerkers was $\mathrm{H}$ artslag Limburg nooit zo een succes geworden. Al die jaren vormde het $\mathrm{H}$ artslagprojectteam een bijzonder trouwe club. M ieke, C hantal, Kitty, M arita, M aria, Patricia, Janneke, Gaby, Jan, Patrick, Pia, Tjerkje, Sandy, André, Ton en Frank, we hebben met elkaar een unieke prestatie geleverd.

D ank heb ik verder voor de sponsors van dit onderzoek. Behalve hoofdsponsor ZonM w wil ik daarin de $\mathrm{N}$ ederlandse $\mathrm{H}$ artstichting betrekken. $\mathrm{M}$ et name W illem de Regt en Volkert $\mathrm{M}$ anger $\mathrm{C}$ ats hebben het destijds vanuit de $\mathrm{H}$ artstichting mogelijk gemaakt dat $\mathrm{H}$ artslag Limburg wetenschappelijk werd geëvalueerd. Zij stonden mede aan de basis van de financiering van dit onderzoek. Een belangrijke bevorderende factor was tevens het 'onderzoeksklimaat' binnen de GGD M aastricht. Voor zijn visie op een 'academische werkplaats avant la lettre' verdient Jan M eijers, destijds directeur, alle lof. Toen ik in mei 2004 de overstap maakte van de GGD naar het N IGZ ondervond ik ook daar de steun en de ruimte om dit onderzoek tot een goed einde te brengen; met name Jan H uurman dank ik voor zijn oprechte interesse. 
D e uitvoering van dit onderzoek heeft ook veel handarbeid en geduld gevraagd. I $\mathrm{k}$ doel dan op de eerste plaats op alle respondenten van enquêtes en interviews. Aan allen die het opbrachten om alle vragen in te vullen dan wel mondeling te beantwoorden wil ik hier nogmaals mijn waardering tot uitdrukking brengen. D it type onderzoek staat of valt bij de bereidheid van respondenten om hun mening te geven, ook al staat daar alleen een al gemeen belang tegenover. $\mathrm{H}$ et is een groot goed dat nog altijd velen die bereidheid tonen.

Wat betreft professioneel handwerk, geduld en zorgvuldigheid kon ik mij geen betere assistent wensen dan Annegreet Wubs. Zij verzorgde de praktische uitvoering van enquêtes en interviews, de invoer in bestanden en een eerste analyse. Een speciaal woord van dank geldt verder de leden van de expertcommissie. Erik, N iek en Léon, jullie opmerkingen bleken essentiële toevoegingen aan het onderzoeksmodel, en daarmee hebben jullie zichtbaar bijgedragen aan het eindresultaat. Aan de validering van de data hebben D ineke Woonink, Lianne de $G$ root en D enise Lejeune bijgedragen als onafhankelijke 'assessors'. D ank voor jullie inzet om al het materiaal door te worstelen en te labelen. Nuttig advies kreeg ik verder van $\mathrm{M}$ aria Jansen, Janneke $\mathrm{H}$ arting, W im Kuiper en W illy de $\mathrm{H}$ aes.

En dan zit alles in een Word-bestand en moet er toch nog veel gebeuren om de tekst geprint en in boekvorm te krijgen. Anne Lies D emesmaeker (directiesecretaresse), M arianne Smit (secretaresse) en John Luteijs (uitgever) stonden daarbij steeds klaar om dit proces soepel te laten verlopen. D e samenwerking met jullie verlichtte voor mij in belangrijke mate de bekende laatste loodjes.

Annelies, jij bent al 25 jaar mijn metgezel in dit leven. Jouw rotsvaste steun heeft altijd gegolden in 'voor- en tegenspoed'. Voor mij blijf je, samen met Esmee en Reinout, het allerbelangrijkste. 


\section{Curriculum Vitae}

Erik Ruland werd op 1 juni 1960 geboren te Tilburg. $\mathrm{H}$ ij groeide op te $\mathrm{N}$ ijmegen, waar hij van 1972 tot 1978 het Canisius College bezocht (VW O -B). Vervolgens studeerde hij van 1978 tot 1986 geneeskunde aan de Katholieke Universiteit N ijmegen. Tijdens de wetenschappelijke keuzestage, met als onderwerp de evaluatie van dorpsgezondheidswerksters in Zuid-India, werd zijn interesse in de sociale geneeskunde gewekt. Van 1986 tot 1988 was hij verpleeghuisarts in verpleeghuis $M$ adeleine te Boxmeer. D aarna verhuisde hij naar $\mathrm{H}$ eerlen waar hij van 1988 tot 1990 werkte als arts Algemene Gezondheidszorg op de afdeling Algemene G ezondheidszorg van de GGD O ostelijk Zuid-Limburg. In 1990 volgde de overstap naar de GGD Zuidelijk Zuid-Limburg te M aastricht waar hij tot 1996 de sociaal medische zorg (arts Indicatiecommissie O uderenzorg) combineerde met taken op het terrein van infektieziektebestrijding, bevolkingsonderzoeken en in toenemende mate het preventiebeleid harten vaatziekten. Van 1992 tot 1995 specialiseerde hij zich in de sociale geneeskunde, tak algemene gezondheidszorg, bij de SSG/N SPO H te U trecht. In 1996 startte hij formeel als projectleider van $\mathrm{H}$ artslag Limburg i.o., het project dat tevens onderwerp is van deze promotiestudie. Tot mei 2004 betrof dit projectleiderschap het leeuwendeel van zijn werk bij de GGD. In maart 2001 ontving $\mathrm{H}$ artslag Limburg de 'Towards U nity for $\mathrm{H}$ ealth field project award', een subsidie van de Wereldgezondheidsorganisatie (W H O) van \$10.000,- voor de verbetering van kennis over 'health system performance at the regional level'. $D$ ankzij een subsidie van ZonM w en de inhoudelijke begeleiding vanuit de Universiteit M aastricht kon hij zich vanaf oktober 2002 tot eind 2006 voor 0,4 fte wijden aan het wetenschappelijk onderzoek. Landelijke contacten leiden vanaf mei 2004 tot een aanstelling bij het $\mathrm{N}$ ationale Instituut voor G ezondheidsbevordering en Ziektepreventie (NIGZ) te Woerden. D aar was hij als adjunct-directeur verantwoordelijk voor het ontwerp en de aansturing van het programma Lokaal Gezond, een landelijk programma gericht op de versterking van het lokale gezondheidsbeleid. Begin 2007 was hij twee maanden waarnemend directeur-bestuurder a.i., en aansluitend directeur interne zaken van het N IGZ. In de tweede helft van 2007 moest het N IGZ afslanken en reorganiseren; vanaf 2008 werkt Erik Ruland als senior staflid kennistransfer.

Erik Ruland is lid van de Commissie 'Gezond Leven' van het programma Preventie van ZonM w.

$\mathrm{H}$ ij is getrouwd en heeft twee kinderen. 